\title{
Technology Assessment on Low-Temperature Waste Heat Recovery in Industry
}

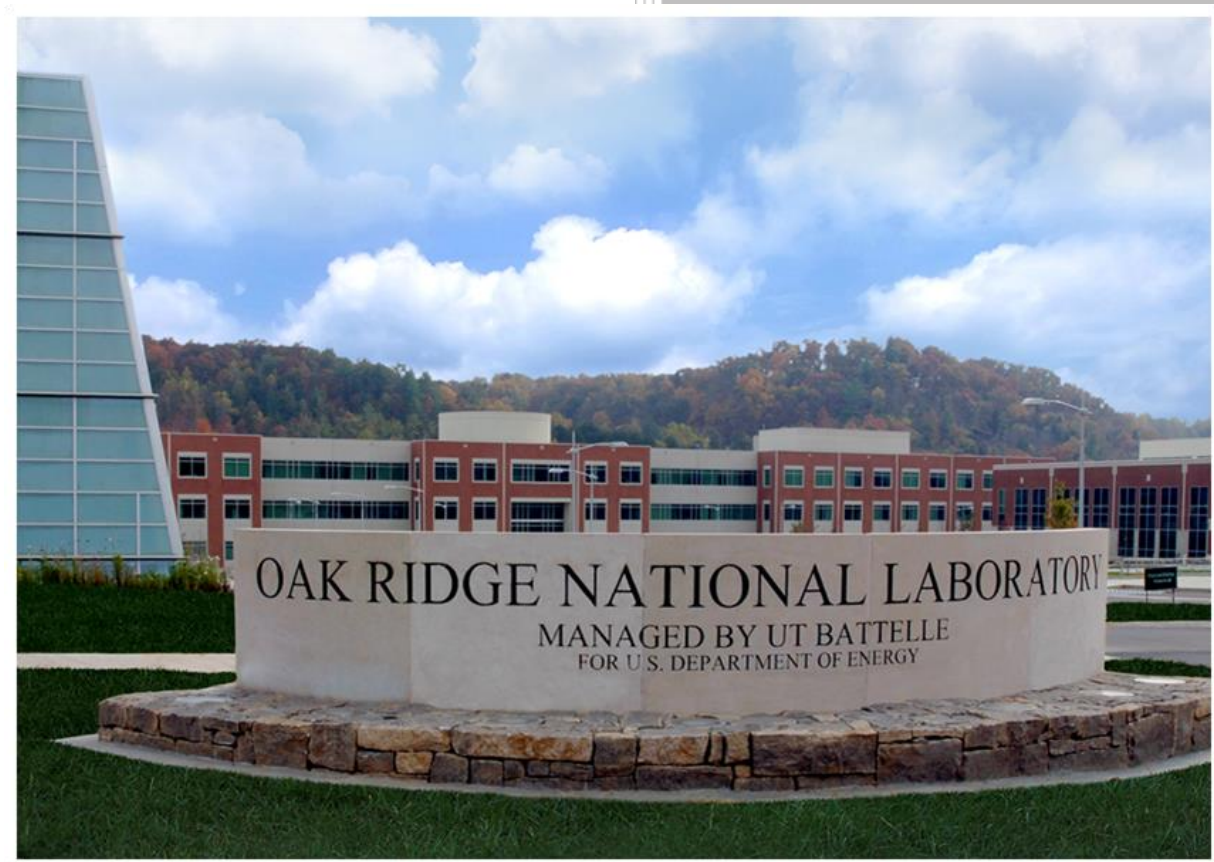

Arvind Thekdi Sachin Nimbalkar Senthil Sundaramoorthy Kristina Armstrong Anthony Taylor Jack Gritton Thomas Wenning Joe Cresko

September 2021 


\title{
DOCUMENT AVAILABILITY
}

Reports produced after January 1, 1996, are generally available free via US Department of Energy (DOE) SciTech Connect.

Website www.osti.gov

Reports produced before January 1, 1996, may be purchased by members of the public from the following source:

\author{
National Technical Information Service \\ 5285 Port Royal Road \\ Springfield, VA 22161 \\ Telephone 703-605-6000 (1-800-553-6847) \\ TDD 703-487-4639 \\ Fax 703-605-6900 \\ E-mail info@ntis.gov \\ Website http://classic.ntis.gov/
}

Reports are available to DOE employees, DOE contractors, Energy Technology Data Exchange representatives, and International Nuclear Information System representatives from the following source:

Office of Scientific and Technical Information

PO Box 62

Oak Ridge, TN 37831

Telephone 865-576-8401

Fax 865-576-5728

E-mail reports@osti.gov

Website http://www.osti.gov/contact.html

This report was prepared as an account of work sponsored by an agency of the United States Government. Neither the United States Government nor any agency thereof, nor any of their employees, makes any warranty, express or implied, or assumes any legal liability or responsibility for the accuracy, completeness, or usefulness of any information, apparatus, product, or process disclosed, or represents that its use would not infringe privately owned rights. Reference herein to any specific commercial product, process, or service by trade name, trademark, manufacturer, or otherwise, does not necessarily constitute or imply its endorsement, recommendation, or favoring by the United States Government or any agency thereof. The views and opinions of authors expressed herein do not necessarily state or reflect those of the United States Government or any agency thereof. 


\title{
TECHNOLOGY ASSESSMENT ON LOW-TEMPERATURE WASTE HEAT RECOVERY IN INDUSTRY
}

\author{
Arvind Thekdi* \\ Sachin Nimbalkar $\dagger$ \\ Senthil Sundaramoorthy $\dagger$ \\ Kristina Armstrong $\dagger$ \\ Anthony Taylor $\dagger$ \\ Jack Gritton† \\ Thomas Wenning $†$ \\ Joe Cresko
}

* E3M, Inc.

$\dagger$ Oak Ridge National Laboratory

$\$$ US Department of Energy

September 2021

Prepared by

OAK RIDGE NATIONAL LABORATORY

Oak Ridge, TN 37831-6283

managed by

UT-BATTELLE, LLC

for the

US DEPARTMENT OF ENERGY

under contract DE-AC05-00OR22725 



\section{CONTENTS}

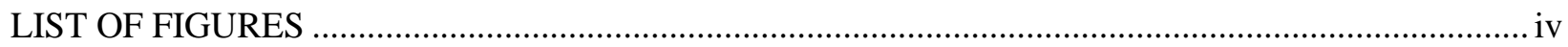

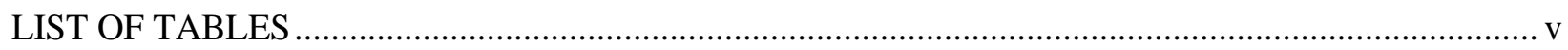

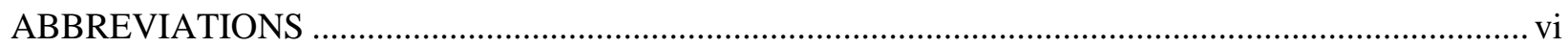

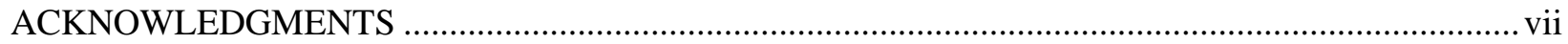

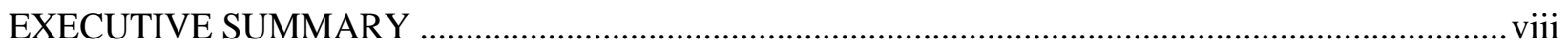

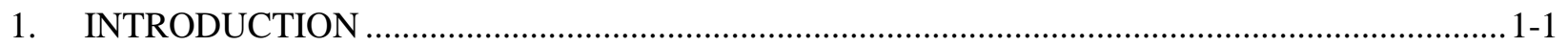

1.1 WASTE HEAT IN EXHAUST GASES AND HEAT RECOVERY ISSUES ...................... 1-1

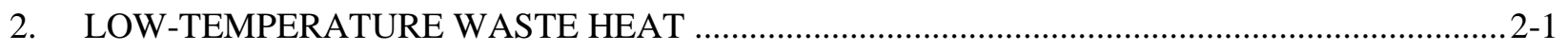

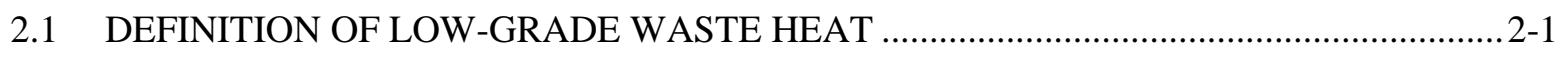

2.2 SOURCES AND CHARACTERISTICS OF LOW-GRADE WASTE HEAT ..................... 2-2

2.3 LOW-TEMPERATURE WASTE HEAT AVAILABILITY …....................................... 2-7

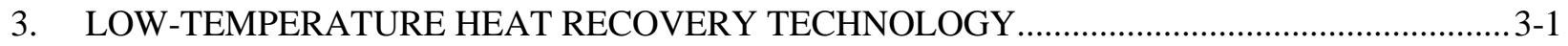

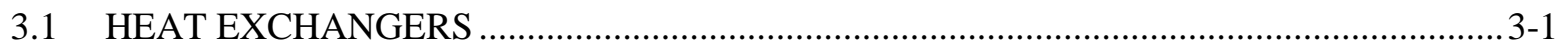

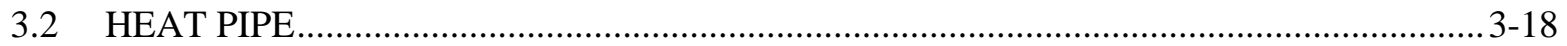

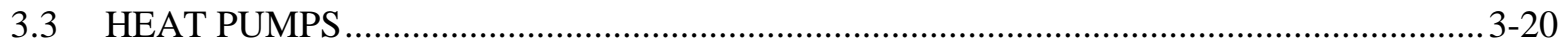

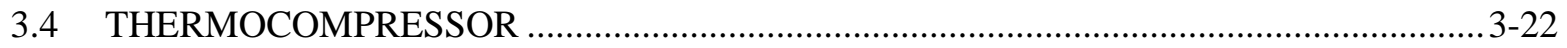

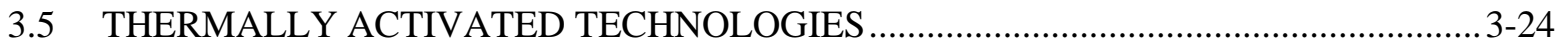

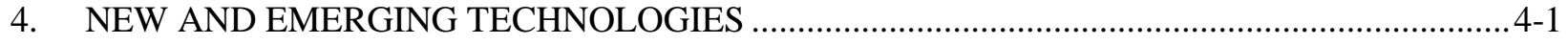

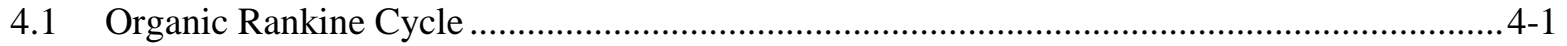

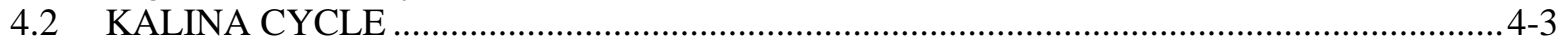

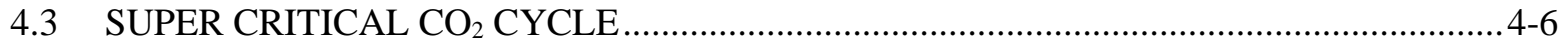

4.4 TRILATERAL FLASH OR VARIABLE PHASE CYCLE …........................................ $4-8$

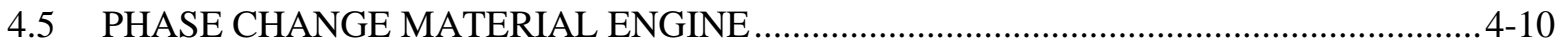

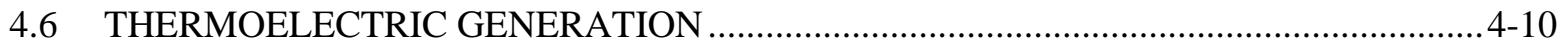

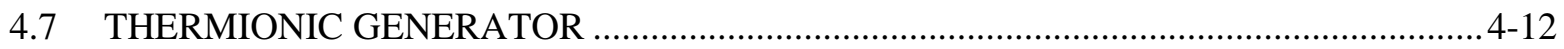

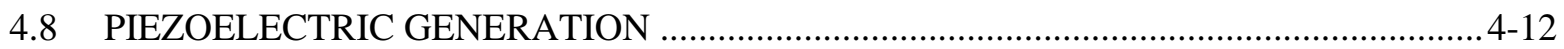

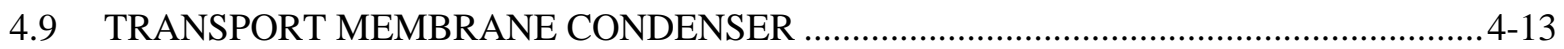

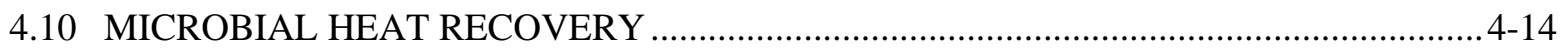

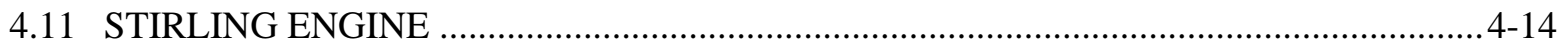

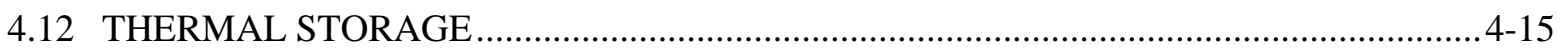

4.13 LOW-TEMPERATURE WASTE HEAT TECHNOLOGIES SUMMARY .......................4-15

5. ECONOMIC OVERVIEW OF LOW-TEMPERATURE WASTE HEAT TO POWER

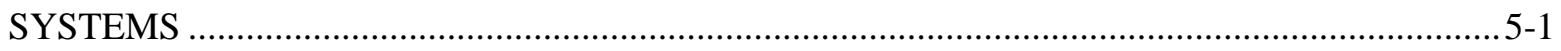

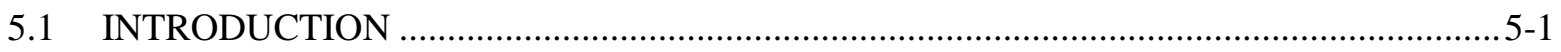

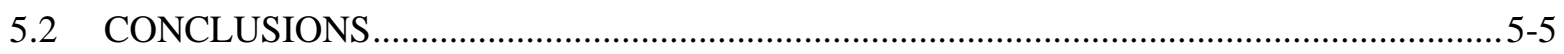

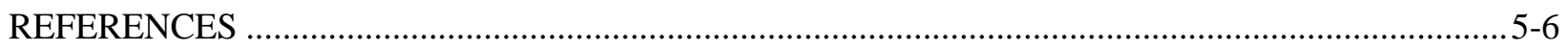

APPENDIX A. LOW-TEMPERATURE WASTE HEAT SOURCES FROM MAJOR

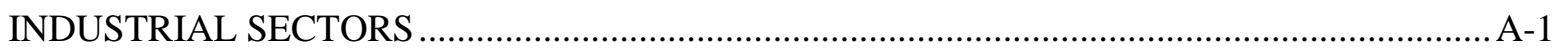

APPENDIX B. LOW-TEMPERATURE WASTE HEAT ESTIMATE BASED ON MECS DATA ....... B-1 


\section{LIST OF FIGURES}

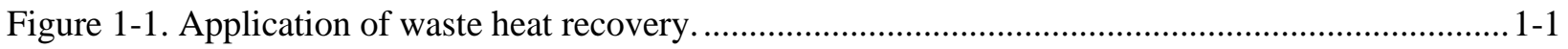

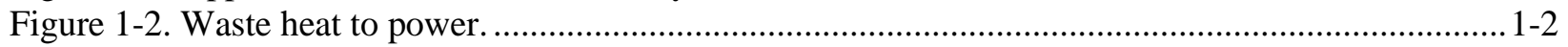

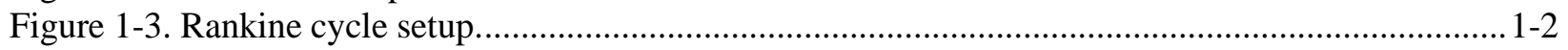

Figure 1-4. Thermoelectric generator technology.................................................................. 1-3

Figure 3-1. Typical single-pass and multiple-pass (U-tube) shell and tube heat exchangers................... 3-2

Figure 3-2. Conventional noncondensing feed water economizer......................................................... 3-5

Figure 3-3. Feed water economizer minimum metal temperature requirement to avoid acid

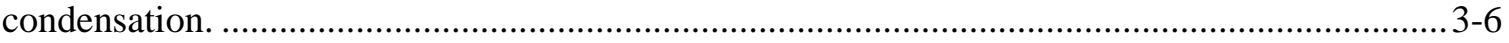

Figure 3-4. Heat recovery by lowering flue gas temperature using a condensing heat exchanger............ 3-7

Figure 3-5. Use of a condensing heat exchanger to increase boiler efficiency....................................... 3-8

Figure 3-6: Installation of a noncontact condensing economizer at a chemical plant. ............................ 3-8

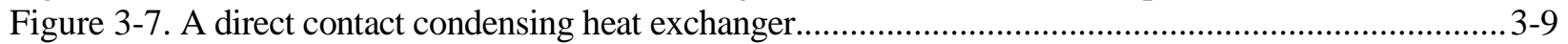

Figure 3-8. Installation of a direct contact condensing heat exchanger on a boiler.............................. 3-10

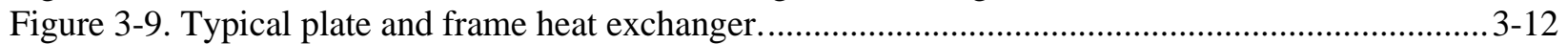

Figure 3-10. Spiral heat exchanger interior construction and the finished unit. ................................... 3-14

Figure 3-11. Typical recuperator design and application for combustion air preheating. .....................3-15

Figure 3-12. Three main configurations of convective recuperators. ................................................ 3-15

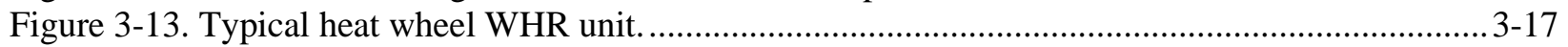

Figure 3-14. A heat pipe construction and functional schematic..................................................... 3-19

Figure 3-15. Assembled unit of heat pipes for use in gas to liquid heat transfer....................................3-19

Figure 3-16. Working principle of a heat pump for heat recovery applications. .................................. 3-21

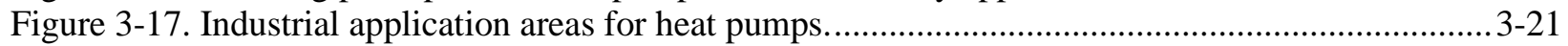

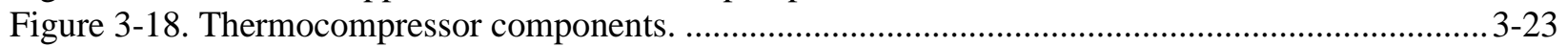

Figure 3-19. Application of a thermocompressor on a paper-drying machine. ..................................... 3-24

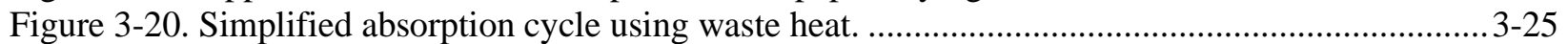

Figure 3-21. Schematic of a single-effect ammonia-water absorption chiller system. .........................3-26

Figure 4-1. Illustration of an industrial ORC technology. ...............................................................

Figure 4-2. ORC applicability based on source temperature and output energy. ..................................... 4-2

Figure 4-3. The ORC in recovering flue gas from CHP................................................................ $4-3$

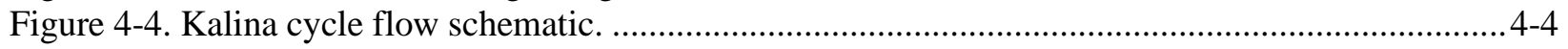

Figure 4-5. Plant size comparison between a $\mathrm{sCO}_{2}$ system and a steam Rankine system...................... 4-6

Figure 4-6. Flow schematic for a simple $\mathrm{sCO}_{2}$ cycle system. .......................................................... 4-7

Figure 4-7. (1) Assembling, (2) shipping, (3) installing, and (4) testing of a $\mathrm{sCO}_{2}$ system in

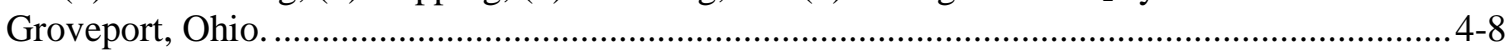

Figure 4-8. Schematic of a simple VPC system..........................................................................

Figure 4-9. Schematic view of a PCM engine system. .......................................................... $4-10$

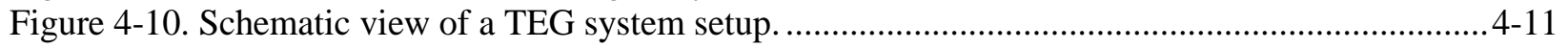

Figure 4-11. Schematic view of a thermionic generator.......................................................... $4-12$

Figure 4-12. Schematic view of TMC system components.............................................................. $4-13$

Figure 4-13. Comparison of industrial waste heat temperatures and WHR technology

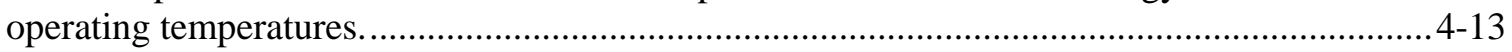

Figure 4-14. Schematic view of a TMC system components. ..................................................... $4-14$

Figure 5-1. Survey results of potential CHP customers and their interest based on time to recuperate investment, adapted from results of a 2003 Primen survey......................................5-1

Figure 5-2. Time-dependent present value of waste heat to power system savings. ..............................5-2

Figure 5-3. Agglomerated cost-size data from industry for comparing different types of waste

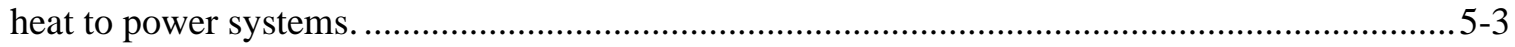

Figure 5-4. Component cost breakdown of an ORC heat recovery system.........................................5-3 
Figure 5-5. Component cost breakdown of a VPC heat recovery system.

Figure 5-6. Component cost breakdown of a Stirling engine heat recovery system...............................5-4

Figure 5-7. Spark spread for selected regions of higher electricity costs.

\section{LIST OF TABLES}

Table 2-1. Temperature range and characteristics for low-temperature industrial waste heat sources.

Table 2-2. Common discharge sources of waste heat and their forms from various energy systems used in a manufacturing plant

Table 2-3. Summary of types of low- and ultralow-temperature heat from different industries.

Table 2-4. Waste heat sources and temperature ranges.

Table 2-5. Estimated additional low-temperature waste heat.

Table 2-6. Estimate of low-temperature waste heat based on top-down analysis..........

Table 3-1. Advantages and disadvantages of shell and tube heat exchangers.

Table 3-2. Advantages and disadvantages of plate and frame heat exchangers.

Table 4-1. An inventory of Kalina cycle recovery systems.

Table 4-2. Current waste heat to power technology inventory.

Table 4-3. Current research into ORC improvements.

Table 4-4. Current waste heat recycling technology database.

Table 4-5. Research into future waste heat to power technology database.

Table 5-1. Model determining payback period of CHP. 


\section{ABBREVIATIONS}

$\begin{array}{ll}\text { CHE } & \text { compact heat exchanger } \\ \text { CHP } & \text { combined heat and power } \\ \text { coefficient of performance } & \text { US Department of Energy } \\ \text { DOE } & \text { US Energy Information Administration } \\ \text { EIA } & \text { heat recovery steam generator } \\ \text { HRSG } & \text { Manufacturing Energy Consumption Survey } \\ \text { MECS } & \text { North American Industry Classification System } \\ \text { NAICS } & \text { operations and maintenance } \\ \text { O\&M } & \text { organic Rankine cycle } \\ \text { ORC } & \text { Oak Ridge National Laboratory } \\ \text { ORNL } & \text { phase change material } \\ \text { PCM } & \text { supercritical CO } \\ \text { SCO } & \text { thermoelectric } \\ \text { TE } & \text { thermoelectric generator } \\ \text { TEG } & \text { transport membrane condenser } \\ \text { TMC } & \text { variable-phase cycle } \\ \text { VPC } & \text { waste heat recovery }\end{array}$




\section{ACKNOWLEDGMENTS}

The authors gratefully acknowledge the support and guidance of Stephen Sikirica and Bob Gemmer of the US Department of Energy's Advanced Manufacturing Office. The authors also thank Subodh Chaudhari, David Vance, William Peter, Craig Blue, Ron Ott, James Parks II, Jennifer Travis, and Olivia Shafer of Oak Ridge National Laboratory who assisted in the development and review of this report. Also, it is a pleasure to acknowledge the help of William Morrow (Lawrence Berkeley National Laboratory), Alberta Carpenter (National Renewable Energy Laboratory), Diane Graziano (Argonne National Laboratory), and Sarang Supekar (Argonne National Laboratory), who reviewed a draft of this report and provided valuable comments.

This work was supported in part by the US Department of Energy, Office of Science, Office of Workforce Development for Teachers and Scientists under the Science Undergraduate Laboratory Internships program. 


\section{EXECUTIVE SUMMARY}

Many manufacturing processes require heat to produce finished products. However, a large percentage of the heat used for the manufacturing operations is lost as low- $\left(<450^{\circ} \mathrm{F}\right)$, medium- $\left(450^{\circ} \mathrm{F}-1,200^{\circ} \mathrm{F}\right)$, or high-temperature $\left(>1,200^{\circ} \mathrm{F}\right)$ waste heat. Most of the waste heat is produced in the form of heat in exhaust or flue gases discharged from heating systems. Heat content of the flue gases includes sensible and latent heat that is produced from the combustion of fossil fuels such as natural gas. Reduction and reuse of this waste heat can increase energy efficiency, reduce greenhouse gas emissions, and increase profits. Waste heat in the low-temperature regime is especially promising because it accounts for more than $50 \%$ of industrial waste heat. Facilities attempt to reduce waste heat (reduction), use low-temperature waste heat within the same process (recycling), or use the heat outside the process in which it is generated (recovery). In the case of heat recovery, waste heat can be used in a different heating process or for conversion to electricity. However, significant barriers remain in implementing low-temperature waste heat recycling or recovery because of challenges such as contaminants in the flue gases, material corrosion related to condensate produced from water condensation, relatively low efficiencies, and long payback periods.

An analysis was conducted to estimate the magnitude of low-temperature waste heat available in the US manufacturing sector and to identify current and emerging low-temperature heat recovery technologies and equipment. The primary focus of the analysis is on the industries that produce the lowest-temperature waste heat: the chemical, primary metal, petroleum, nonmetallic mineral, fabricated metal, food, paper, and wood industries. In addition to identifying the waste streams, their characteristics, and currently available heat recovery technologies, the study also explored future research opportunities and economic barriers for recovery technology implementation. Special attention was given to applicable heat to power conversion technologies such as the organic Rankine cycle, thermoelectric conversion, and the supercritical $\mathrm{CO}_{2}$ cycle. The study included investigations in research and new developments, including turbine and heat exchanger cost for waste heat to power systems, size, efficiency, and intermittency of waste heat streams.

Results indicate that recycling or reducing waste heat, when economically justified, should be the first step since it is the most efficient and cost-effective in most cases. In this case, energy is not converted from one form to another and synchronization of heat supply and heat demand is not essential. In most cases, changes in the infrastructure are minimal and the project cost could be justifiable. When no good option exists for use of heat for recycling or reduction, the organic Rankine cycle is often the most costeffective method for converting waste heat to electric power. Several new and emerging technologies are being pursued for waste heat to power conversion; however, their industrial applications, particularly for the low-temperature regime, could be several years away. 


\section{INTRODUCTION}

\subsection{WASTE HEAT IN EXHAUST GASES AND HEAT RECOVERY ISSUES}

Discharge of low-grade waste heat at lower than $450^{\circ} \mathrm{F}$ from industrial facilities contributes to a large amount of wasted energy, increase in $\mathrm{CO}_{2}$ or greenhouse gas emissions, and increased cost. This report describes the results of several studies carried out by the US Department of Energy's (DOE's) Oak Ridge National Laboratory (ORNL) and E3M, Inc., and it includes sources, amounts, and characteristics of waste heat with details of current and emerging technologies to recover low-grade waste heat. The focus of this study is the US manufacturing sector, based on available data and technology information for 2008 to 2011. The amount of low-grade waste heat, based on $120^{\circ} \mathrm{F}$ as a reference temperature, from the manufacturing sector is about 1,180 TBtu per year, approximately 53\% of the unrecovered waste heat in industry. ${ }^{1}$ Although this waste heat is significant and could provide a good opportunity for recovery, several challenges exist in extracting and collecting this heat, transporting it from the source of the waste heat to the point of use, and using or transforming it to a usable form.

One way in which waste heat is recovered is by transporting the heat from the source (process or equipment) to another process or equipment that can use the heat in thermal form. For example, as shown in Figure 1-1, the waste heat from a heating process or heat source can be used for other applications such as preheating water, producing low-pressure steam, space heating, and cooling through use of absorption cooling technology. The exhaust heat, if at a high enough temperature, can also be used in another heating process.

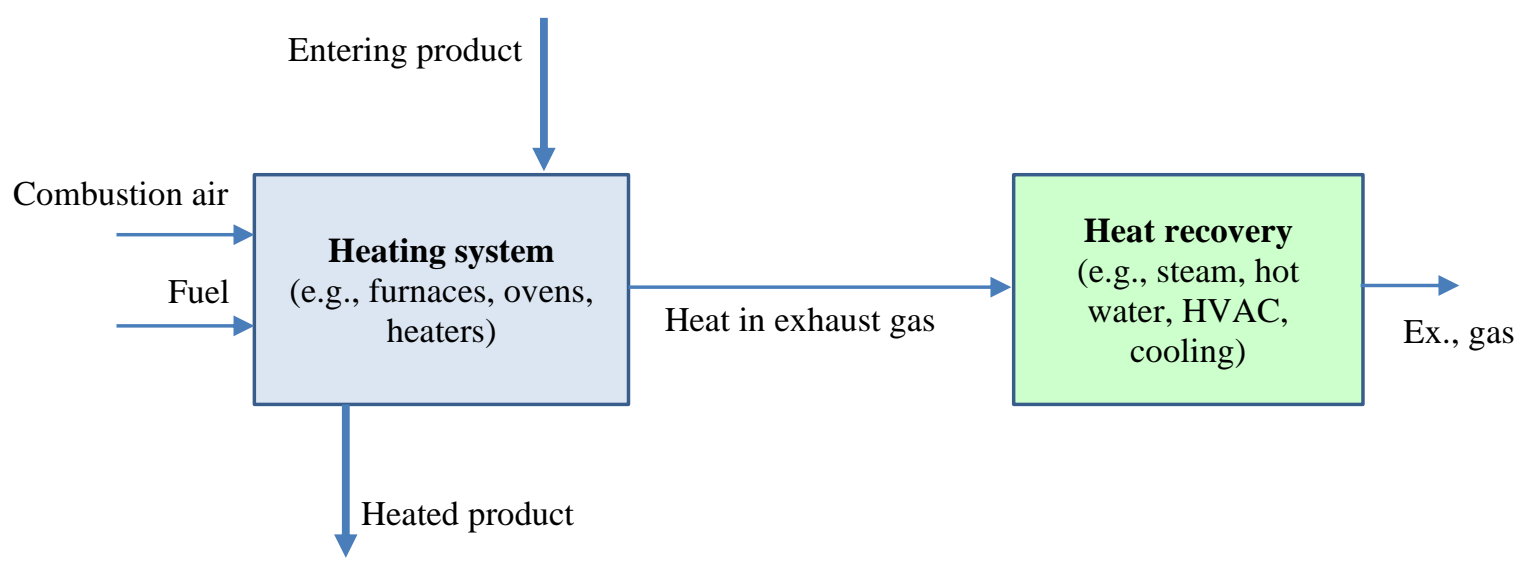

Figure 1-1. Application of waste heat recovery.

Technologies and systems to recover heat for the purposes mentioned are well established. In most cases, heat recovery requires some type of heat exchanger; a large variety of direct and indirect heat exchanger designs have been developed and used by the industries. Developments focus on reducing the size of the equipment, using better materials, improving heat exchanger cleaning methods, and using advanced methods for preventive maintenance. However, there is still considerable room for improvement in the performance of the equipment, as well as cost reduction through improvements, innovations, or even disrupting technologies.

Waste heat-to-power systems is another common recovery technology; Figure 1-2 illustrates a generalization in which the waste heat stream is directed toward a heat to power conversion system. Many options are available for actual configuration and hardware for the heat to power systems, including the 
use of the Rankine cycle, or direct conversion of heat to electricity through the use of technologies such as thermoelectric (TE) power generation.

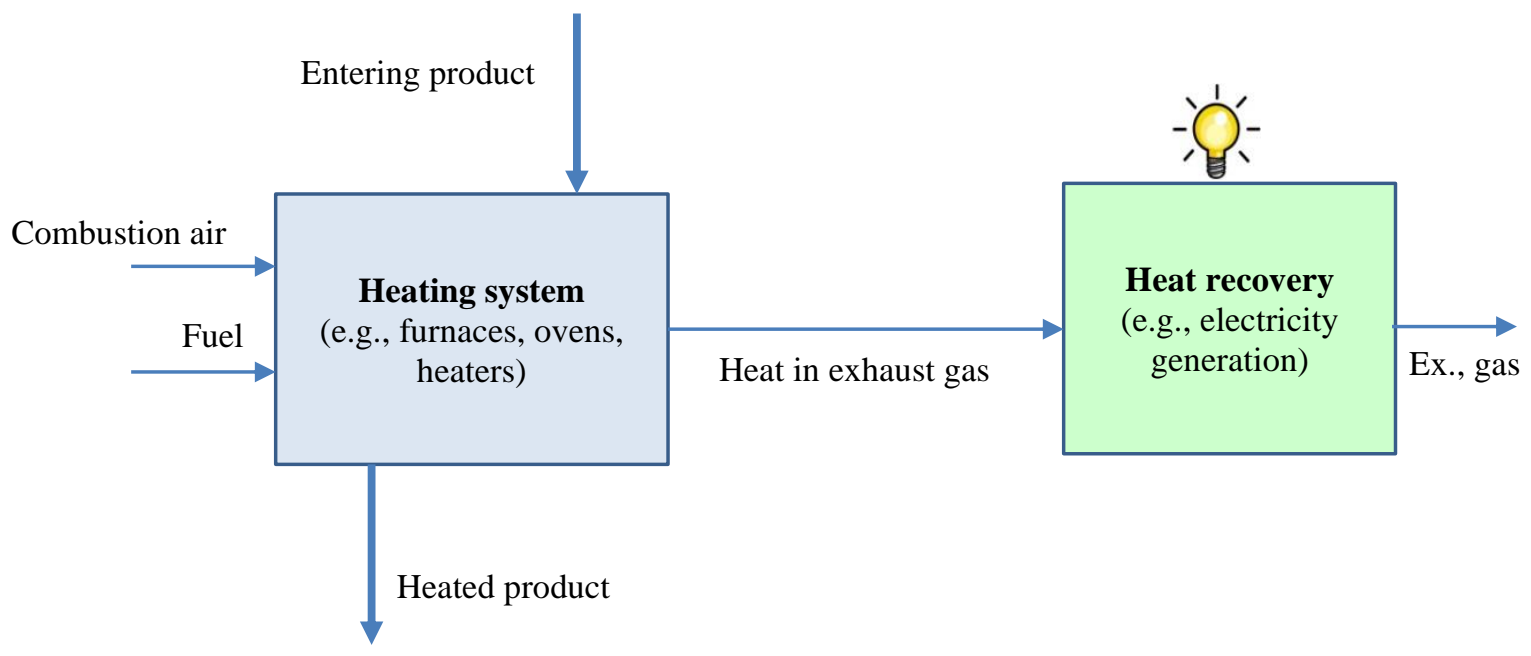

Figure 1-2. Waste heat to power.

In Rankine cycle-based systems, as shown in the schematic diagram in Figure $1-3,{ }^{11}$ the waste heat stream enters the power generation system and transfers its heat to the pressurized working fluid (water) in the evaporator or "boiler" section. The working fluid is selected in such a manner that it can operate within the temperature range available from the waste heat source. The working fluid is water in the case of a steam Rankine cycle. In the case of the organic Rankine cycle (ORC), an organic fluid that can boil at low temperatures, such as refrigerants, are used as the working fluid. With adequate temperature of the waste heat stream and selection of proper working fluid, the system converts the working fluid into a vapor, typically superheated, state. The high-pressure vapor enters a turbine, spinning the blades and reducing the vapor pressure. The turbine connects to an electrical generator, which converts the mechanical energy of turbine rotation into electricity. The low-pressure working fluid exiting from the turbine enters the condenser, which uses water or air to cool the vapor, condensing it to a liquid. Finally, a pump pressurizes the liquid to send it to the evaporator or boiler section and repeat the cycle.

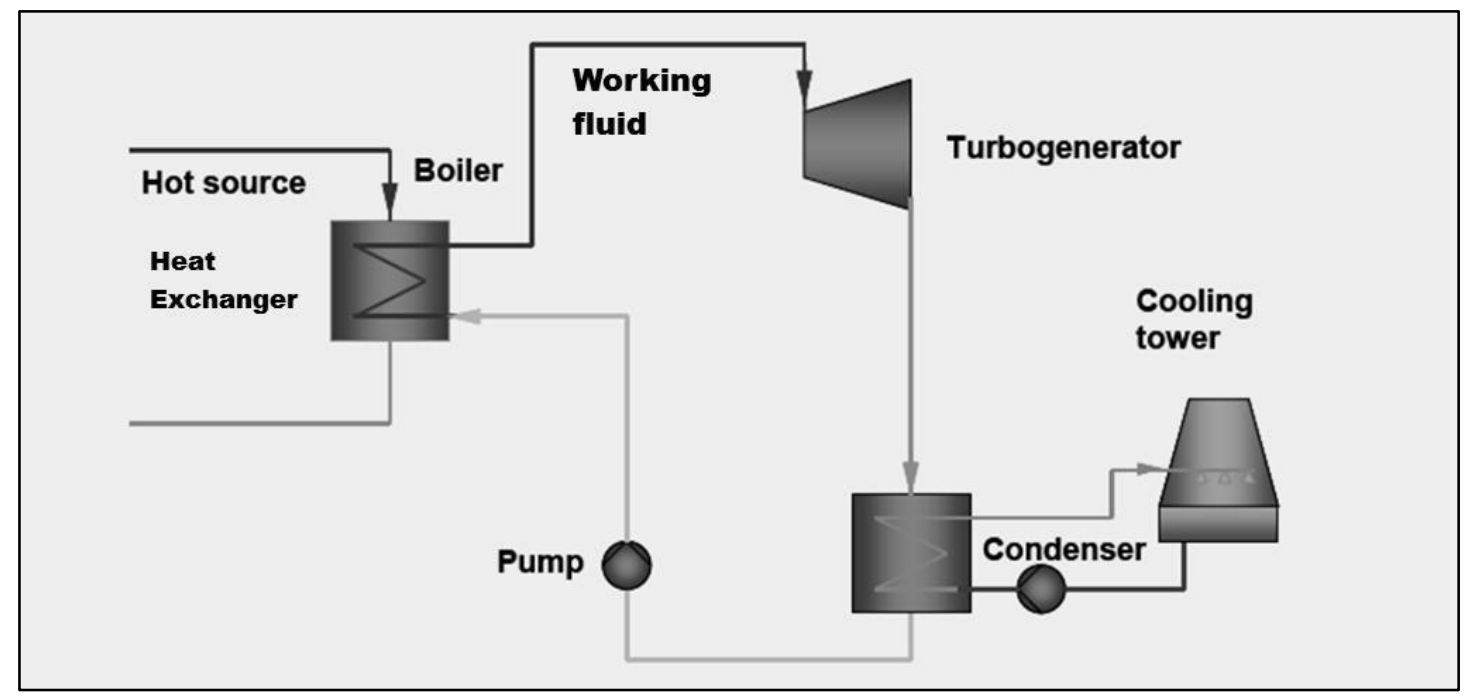

Figure 1-3. Rankine cycle setup. 
Low-temperature power generation is a developing field with a large amount of research directed toward developing efficient and low-cost components (e.g., heat exchangers, turbines, condensers). There are many variations of the conventional steam cycle, such as Rankine cycle discussed previously, that are used to generate electrical power, though all of them generally use a rotating turbine attached to a generator to convert mechanical energy to electrical energy.

Another method of waste heat-to-power conversion is direct conversion using the Seebeck effect, named after the inventor Thomas Johann Seebeck. Commonly known as TE power generation, when heat is applied to the hot side of a TE generator and the cold side is maintained at as low of a value as possible, electricity is produced (Figure 1-4). Almost any heat source at temperatures above $400^{\circ} \mathrm{F}$ can be used to maintain hot side temperatures. Efficiency (expressed in terms of electric energy generated divided by the amount of heat supplied) of a TE system is relatively low, usually in the range of $2 \%$ to $5 \% .{ }^{10}$

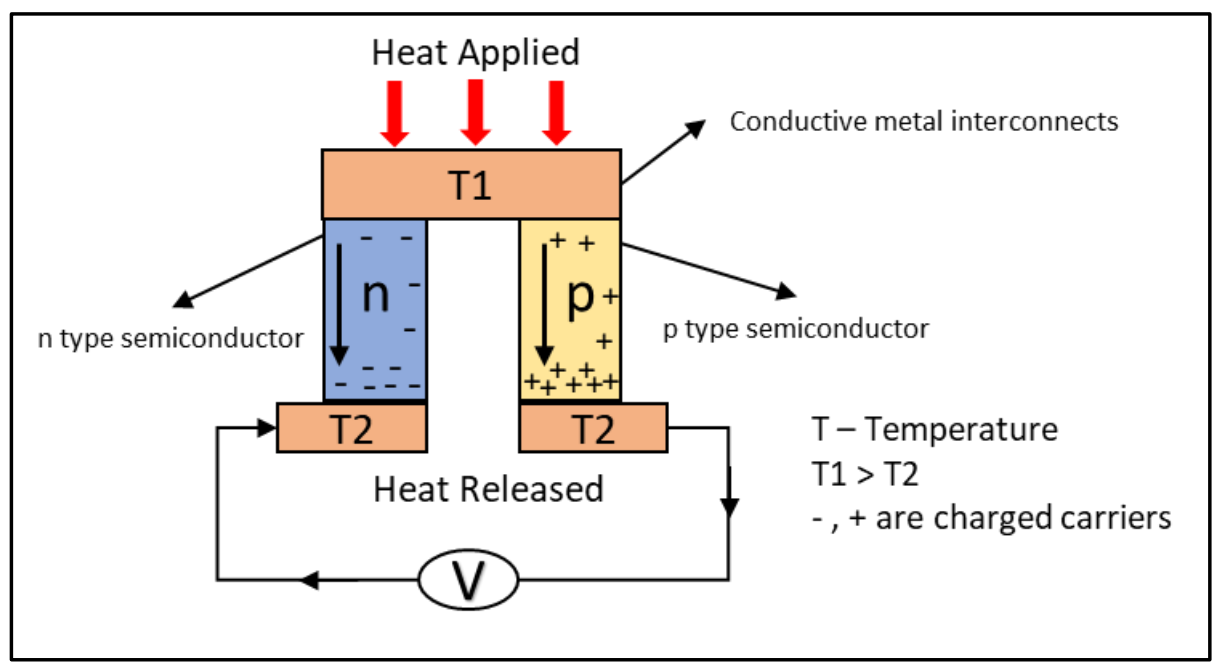

Figure 1-4. Thermoelectric generator technology.

Historically, the cost of thermoelectric power generation has been high because of limitations in material knowledge and associated processing issues. Recent technology developments in material science and advanced manufacturing techniques have demonstrated a high potential for reduced production costs. However, for the foreseeable future, use of TE devices for waste heat recovery (WHR) in industries is not considered practical because of their low efficiency and historically high initial costs. More details of the technology and its application are discussed in Section 4.6.

Transporting heat to another process in the facility is highly efficient compared with waste heat-to-power technologies. Because conversion between forms always results in a loss of energy, efficiency on heat cycles is physically limited as described by the Carnot cycle. However, in many facilities, finding a use for low-grade heat in other processes is difficult, but many processes in the facility can use electricity. Waste heat to power is often the best option when the facility does not have another process that can use the recovered heat.

This review of the advances in low-grade WHR technology provides information required by industries to determine if WHR is worth the investment. The payback period, or the number of years for the savings introduced by the new system to pay for its costs, is a useful decision-making criterion for WHR implementation. Facility investment decisions are often made based on economic considerations rather than environmental benefit reasons. In the past, the high cost of recovering waste heat in the lowtemperature range prevented industries from making investments in WHR. The present and future research may result in new technologies with lower cost and higher overall energy conversion efficiency 
for low-temperature WHR, increasing the cost-effectiveness and potentially the uptake by industry. Additionally, the government considers environmental benefit and energy savings as important criteria in the decision-making process. Thus, public policy could play a role in encouraging the uptake of the WHR industry through considering energy and environmental benefits.

This report presents details of important factors in low-temperature heat recovery, currently available and used WHR technologies, as well as emerging technologies that may allow wider use of low-temperature WHR. 


\section{LOW-TEMPERATURE WASTE HEAT}

This section discusses details of low-temperature waste heat in different industries, reporting the magnitude of low-temperature waste heat $\left(\right.$ at $<450^{\circ} \mathrm{F}$ ) as characterized in the previous chapter. These values should be considered rough approximations because of the assumptions, approximations, and age of the data used for computation, but they do illustrate the general trends in waste heat generation from various industrial processes. Three different approaches for estimating low-temperature waste heat for the manufacturing sectors (NAICS [North American Industry Classification System] 311 to 339) resulted in significant variation, from $905 \mathrm{TBtu} /$ year given in a BCS, Inc. report ${ }^{2}$ to $1,182 \mathrm{TBtu} /$ year given in a ICF International report. ${ }^{1}$ Another approach using MECS data indicated that the low-temperature waste heat could be between 1,084 and 1,637 TBtu/year (Refer Table 2-6). These differences could be due to using different reference temperatures, assumptions made in estimates, and accounting for secondary lowtemperature heat from high-temperature heat sources after heat recovery is used. In any case, the amount of recoverable or unrecovered low-temperature waste heat energy is a large percentage (50\% to $60 \%$ ) of the total energy used in manufacturing. Despite the large amount of total energy, these sources have low exergy, resulting in lower recoverable energy. Thus, these systems have a low efficiency than highertemperature systems.

Waste heat is recovered in three ways: by heating or preheating another process stream, converting it to electricity, or recycling it back into the same process. In most industrial facilities, the low-grade waste heat is converted into electricity since finding other processes that can use this low-grade waste heat is difficult. Though conversion will inherently have energy losses, converting waste heat to power is beneficial when economical, and continued research in this area is improving reliability and cost.

\subsection{DEFINITION OF LOW-GRADE WASTE HEAT}

Areas or subsystems that use energy in a manufacturing facility or an industrial plant produce waste heat. In most cases, the important characteristics of waste heat are the form in which they are available (e.g., gas, liquid, or solid) and their temperature (low, medium, and high). The waste heat temperature influences the analysis of waste heat sources and recovery; therefore, the temperature regimes for waste heat-related discussions must be clearly identified. A BCS report ${ }^{2}$ prepared in 2008 identified three temperature ranges to classify waste heat sources and opportunities; however, there is no general agreement or basis for this definition of the temperature ranges. A later report (prepared in 2011 by E3M, Inc. and $\mathrm{ORNL}^{3}$ ) expanded the temperature ranges on high and low ends of the spectrum. This allows for the exploration and identification of waste heat use and $R \& D$ opportunities in temperature ranges below $250^{\circ} \mathrm{F}$ (ultralow-temperature) and higher than $1,600^{\circ} \mathrm{F}$ (ultrahigh-temperature), where it is difficult to identify cost-effective WHR methods or equipment. Therefore, the report recognizes the following five temperature ranges:

- Ultralow temperature: $\left\langle\mathbf{2 5 0}^{\circ} \mathbf{F}\right.$. The lower temperature for this range is usually the ambient temperature or the temperature of a cooling medium such as cooling tower water or other water used for cooling systems. The upper limit is based on several considerations, such as the condensation temperature of combustion products or flue gases (usually below $180^{\circ} \mathrm{F}$ for natural gas combustion products); the applicability of low temperature is based on nonoxidizing materials such as aluminum or nonmetallic materials such as polymers or plastics, or the use of low-temperature WHR systems such as heat pumps.

- Low temperature: $\mathbf{2 5 0}^{\circ}-\mathbf{4 5 0}^{\circ} \mathbf{F}$. Waste heat in this temperature range is available in hot gases discharged from ovens, heaters, and so on, and in the form of steam, hot products, hot surfaces, and so on. 
- Medium temperature: $\mathbf{4 5 0}^{\circ}-\mathbf{1 , 2 0 0}^{\circ} \mathbf{F}$. Waste heat in this temperature range is available in combustion products, hot gases discharged from ovens, heaters, and so on. It is in the form of hot surfaces in certain equipment such as cement kilns, liquid metal ladles, and glass melting furnaces.

- High temperature: $\mathbf{1 , 2 0 0}^{\circ}-\mathbf{1 , 6 0 0}^{\circ} \mathbf{F}$. This is the normal definition of the high-temperature range based on availability of equipment and material. However, the BCS report defined $>1,200^{\circ} \mathrm{F}$ to be "high." This BCS range is based on contacts with the industry and WHR equipment suppliers; we suggest that the high-temperature range be divided in two temperature ranges. Waste heat available from hot gases discharged from ovens, furnaces, incinerators, and so on fall under this temperature category.

- Ultrahigh temperature: $>\mathbf{1 , 6 0 0}{ }^{\circ} \mathbf{F}$. WHR from streams above $1,600^{\circ} \mathrm{F}$ requires use of special hightemperature materials that can be metallic or nonmetallic, such as ceramics. Selection of material and equipment design becomes critical in many cases; as waste heat streams at such high temperatures contain a large number of contaminants.

This report discusses the ultralow- and low-temperature ranges (i.e., temperature below $450^{\circ} \mathrm{F}$ ) of waste heat and we will use the term "low-temperature" to simplify the discussion in this report.

\subsection{SOURCES AND CHARACTERISTICS OF LOW-GRADE WASTE HEAT}

A large source of low-temperature waste heat for most industries includes hot gases or air from heating systems such as boilers, heat treat ovens, dryers, fired heaters, hot solids leaving a furnace or oven and hot liquids from process heat exchangers and other cooling systems. Waste heat in the form of exhaust gases is readily recognized but the heat content of solids discharged from heating equipment and hot liquids are often ignored.

Some of the low-temperature waste heat in different forms and sources include the following:

i. Waste heat sources in low-temperature gases such as air and steam include heat from compressed air, vented steam leaks, HVAC exhaust air, and more.

ii. Waste heat in liquids include heat from cooling water, heated wash water, and boiler blow-down water.

iii. Low-temperature waste heat in solids includes heat contained or emitted from hot products that are discharged after processing or after reactions are completed, material handling systems such as baskets, trays, conveyors etc.

iv. Other sources that are less obvious include hot by-products, such as ash or slag from processes or combustion of solid materials, radiation from heating systems (e.g., ovens, furnaces), and furnace walls.

In addition to the mentioned sources, electric systems (e.g., electric motors, electrical transmission lines, transformers, switch gear) and cooling systems (e.g., cooling towers, liquid coolers, or heat exchangers using ambient air, cooling ponds) are also sources of low-temperature waste heat. The total amount of heat discharged in these forms is very large; however, recovering and using the heat can be difficult at economically justifiable means.

Additional sources of low-temperature waste heat outside the heating equipment include the following plant energy systems: 
i. Steam systems, including steam generators or boilers, steam distribution, use or end-use, and condensate return systems

ii. On-site power generation using internal combustion engines, gas turbines, micro turbines, steam turbines, fuel cells, and so on

iii. Compressed air systems (compressors, air distribution, and end-use), which may use electric motors, steam drives (i.e., steam turbine), or reciprocating engines to drive compressors

iv. Air conditioning and cooling systems used as part of manufacturing or the plant HVAC facilities

v. Plant facilities, including centralized heating - cooling facilities, on-site transportation, and other energy systems

Regardless of the type of application, there is always some energy loss associated with these systems. Most of these losses are in the form of sensible heat. However, a few sources, such as moist air and steam, may contain latent heat as a large percentage of the total heat content of the waste heat. Other sources of waste heat (e.g., gases from reactors, gasifiers, ore reduction processes) may contain heat in the form of chemical or reactive component heat, but it is not always possible to recover this heat in a practical and economically viable way. The following sections briefly describe some of the major low temperature waste heat sources.

\section{Industrial Furnaces, Ovens, Heaters, and More}

Industrial furnaces and other similar equipment (e.g., ovens, heaters, dryers) are typically fuel-fired systems used in manufacturing facilities. These systems transfer heat to the charge material, generated from combustion of different types of fuels such as fossil fuels, byproduct gases, liquid fuels (fuel oils), and solid fuels (coal, biomass, solid waste). Furnaces discharge flue gases or combustion products (occasionally mixed with additional air or moisture) as waste heat. Electricity is also a source of heat, with no locally produced combustion products; however, these furnaces still discharge waste heat in the form of hot and possibly humid air that is required for process safety or ventilation. This equipment operates in a very broad temperature range, from as low as $250^{\circ} \mathrm{F}$ to as high as $3,000^{\circ} \mathrm{F}$, discharging waste heat in the same or lower temperature range. Depending on the process carried out within the heating equipment, flue gases may contain combustion products or various additional components, referred to as "contaminants." These gases are discharged at temperature higher than the condensation temperature of the moisture content. This maintains the gas temperature at or above $150^{\circ} \mathrm{F}$. Much of the heat content of discharged gases is in the form of latent heat of the moisture. Selection and use of waste heat recovery equipment depends on several factors, such as temperature, flow rate, and quality of the gases; a process heating source book ${ }^{4}$ provides more information on process heating equipment use and operation.

\section{Boilers-Steam Generators}

Manufacturing plants often rely on boilers for steam generation for use in a plant or to produce electrical power. Boilers use fossil fuels, such as natural gas, coal or by-product fuels, to supply necessary heat for steam production. More information on boiler types, sizes, and operating practices are given in the Steam System Survey Guide. ${ }^{5}$ For large boilers, it is common to use the economizers that preheat boiler feed water by recovering portion of the exhaust gas heat and, in some cases, combustion air preheaters to recover more heat from the exhaust gases. However due to potential corrosion issues, the exhaust gas temperature is typically maintained between $150^{\circ} \mathrm{F}$ to $250^{\circ} \mathrm{F}$. The exact temperature depends on sulfur content of the fuel. A special class of boilers, heat recovery steam generators (HRSGs), use the sensible heat of exhaust gases from prime movers such as gas (combustion) turbines or large reciprocating 
engines. These boilers operate within a narrow temperature range of $300^{\circ} \mathrm{F}$ to $500^{\circ} \mathrm{F}$, with a flue gas oxygen content of $2 \%$ to $5 \%$, making it easy to identify heat recovery systems and estimate recoverable heat.

\section{Gas (Combustion) Turbines}

Industry uses gas turbines, also known as "combustion turbines," for power production or as part of combined heat and power (CHP) systems that deliver electrical power and steam, usually within large energy user complexes such as petroleum refineries, paper mills, and chemical plants. Gas turbines produce electrical power, measured in megawatts, and deliver exhaust gases in a temperature range of $700^{\circ} \mathrm{F}$ to $950^{\circ} \mathrm{F}$. Most gas turbine installations use HRSGs to recover part of the exhaust gas heat. Flue gases from HRSGs are in the temperature range of $300^{\circ} \mathrm{F}$ to $450^{\circ} \mathrm{F}$ and may contain $3 \%$ to $5 \%$ oxygen (more information on gas turbine-based HRSG installation is available from the US Environmental Protection Agency ${ }^{6}$ ). As with boilers, it is possible to recover this low-grade heat by using some of the technologies discussed in Section 4.

\section{Reciprocating Engines}

Reciprocating engines are used as prime movers for driving rotary equipment, such as compressors, pumps, electric generators. They use natural gas or diesel fuel and discharge waste heat in three forms. About $30 \%$ of the heat input is lost in exhaust gases at a temperature higher than $700^{\circ} \mathrm{F}$. The other two forms of waste heat are engine jacket coolants and lubrication oil cooling systems. These two sources of heat are at about $275^{\circ} \mathrm{F}$ to $450^{\circ} \mathrm{F}$. More information on reciprocating engines is given by the US Environmental Protection Agency. ${ }^{6}$ Reciprocating engines are well suited for CHP in commercial and light industrial applications of less than $5 \mathrm{MW}$. Smaller engine systems produce hot water and larger systems can produce low-pressure steam. Multiple reciprocating engines can be used to increase system capacity and enhance overall reliability.

\section{Microturbines}

Microturbines are small, compact, lightweight combustion turbines that typically have power outputs of 30 to $300 \mathrm{~kW}$ and use a variety of fuels, including natural gas and liquid fuels. A heat exchanger recovers thermal energy from the microturbine exhaust to produce hot water or low-pressure steam. Exhaust gas temperature from a microturbine depends on the degree of heat recovery. In designs with a recuperator to preheat intake air, the exhaust gas temperate is only about $260^{\circ} \mathrm{F}$; without a recuperator, the exhaust gas temperature is about $500^{\circ} \mathrm{F}^{7}$ The thermal energy from the heat recovery system can be used for potable water heating, absorption cooling, desiccant dehumidification, space heating, process heating, and other building uses.

\section{Fuel Cells}

Fuel cells are an emerging technology with the potential to serve power and thermal needs with very low emissions and high electrical efficiency. Fuel cells use an electrochemical or battery-like process to convert the chemical energy of the oxidation of a fuel (typically hydrogen into water) into electricity. The hydrogen can be obtained from processing natural gas, coal, methanol, and other hydrocarbon fuels. As a less mature technology, fuel cells have high capital costs, an immature support infrastructure, and technical risk for early adopters. However, the advantages of fuel cells include low emissions and noise, high power efficiency over a range of load factors, and modular design. 
For industrial heating processes, the temperature of exhaust gas or air depends on the process operating temperature, heating system design, and operating practices. Table 2-1 shows the most common sources of low-temperature waste heat sources, their temperature range, and the cleanliness of these gases. ${ }^{3}$

Table 2-1. Temperature range and characteristics for low-temperature industrial waste heat sources.

\begin{tabular}{|l|c|l|}
\hline \multicolumn{1}{|c|}{ Waste heat source* } & Temperature range & \multicolumn{1}{c|}{ Cleanliness } \\
\hline Oven, dryer-type heating system exhaust gases & $250^{\circ} \mathrm{F}-500^{\circ} \mathrm{F}$ & Varies \\
\hline Reciprocating engines Jacket cooling water & $190^{\circ} \mathrm{F}-200^{\circ} \mathrm{F}$ & Clean \\
\hline Reciprocating engines exhaust gases (for gas fuels) & $400^{\circ} \mathrm{F}-1,100^{\circ} \mathrm{F}$ & Mostly clean \\
\hline Hot surfaces & $150^{\circ} \mathrm{F}-600^{\circ} \mathrm{F}$ & Clean \\
\hline Compressor after-inter-cooler water & $100^{\circ} \mathrm{F}-180^{\circ} \mathrm{F}$ & Clean \\
\hline Hot products & $200^{\circ} \mathrm{F}-2,500^{\circ} \mathrm{F}$ & Mostly clean \\
\hline Steam vents or leaks & $250^{\circ} \mathrm{F}-600^{\circ} \mathrm{F}$ & Mostly clean \\
\hline Condensate & $150^{\circ} \mathrm{F}-500^{\circ} \mathrm{F}$ & Clean \\
\hline Emission control devices-thermal oxidizers and so on & $150^{\circ} \mathrm{F}-1,500^{\circ} \mathrm{F}$ & Mostly clean \\
\hline Cooling water from cooling systems & $120^{\circ} \mathrm{F}-250^{\circ} \mathrm{F}$ & Mostly clean \\
\hline
\end{tabular}

*This does not include sources at lower than $120^{\circ} \mathrm{F}$. This includes gases or liquids from condensers, HVAC exhaust air, water from washing systems in the food industry, and more.

As mentioned earlier, low-temperature waste heat is discharged in many different forms depending on the heat source. Commonly available forms include sensible heat in solids, liquids, and gases; latent heat of fusion or melting; heat of condensation; and chemical heat as combustible gases, vapors, solids (see Table $2-2)$.

Different industries generate and discharge waste heat from different sources in a variety of forms. The quality and amount of the waste heat determines the possibility of heat recovery and type of equipment needed. Table 2-3 provides a summary of types of low- and ultralow-temperature heat from different industries. Low-temperature waste heat is produced in all industries, despite industries having widely varied process temperatures. For example, industries such as steel, glass, and cement use a very hightemperature material processing; however, because of the use of heat recovery systems, the final waste stream (mostly in the form of flue gases) is at a low temperature because of thermodynamic and economic limitations of heat recovery systems used in these industries.

The amount of waste heat depends on the energy or heat input, and composition and temperature of the waste stream. The manufacturing sector uses hundreds of different processes and several types of processing systems or equipment for each process. Additionally, production rate or processing rate for the equipment changes to meet production requirements. Hence, knowledge of waste heat characteristics as well as annual energy use data is required to estimate the total amount of waste heat available.

The following section discusses various approaches used to estimate low-temperature waste heat, including a review of available information and calculations based on other information. 
Table 2-2. Common discharge sources of waste heat and their forms from various energy systems used in a manufacturing plant.

\begin{tabular}{|c|c|c|c|c|c|c|c|c|}
\hline No. & Waste heat source & $\begin{array}{l}\text { Sensible- } \\
\text { latent heat } \\
\text { content in } \\
\text { gases or } \\
\text { air }\end{array}$ & $\begin{array}{l}\text { Chemical } \\
\text { heat } \\
\text { content in } \\
\text { gases }\end{array}$ & $\begin{array}{l}\text { Sensible } \\
\text { heat in } \\
\text { liquids }\end{array}$ & $\begin{array}{l}\text { Sensible } \\
\text { heat in } \\
\text { solids }\end{array}$ & $\begin{array}{c}\text { Exothermic } \\
\text { heat of } \\
\text { reaction }\end{array}$ & $\begin{array}{l}\text { Radiation/ } \\
\text { convection } \\
\text { from hot } \\
\text { surfaces }\end{array}$ & $\begin{array}{c}\text { Heat in } \\
\text { steam or } \\
\text { condensable } \\
\text { vapors }\end{array}$ \\
\hline 1 & $\begin{array}{l}\text { Fuel-fired boilers } \\
\text { or steam generators }\end{array}$ & $\mathrm{X}$ & & $\mathrm{X}$ & & & $\mathrm{X}$ & $\mathrm{X}$ \\
\hline 2 & $\begin{array}{l}\text { Steam systems, } \\
\text { including } \\
\text { distribution, use, } \\
\text { and condensate } \\
\text { return }\end{array}$ & & & $\mathrm{X}$ & & & & $\mathrm{X}$ \\
\hline 3 & $\begin{array}{l}\text { Industrial heating } \\
\text { equipment such as } \\
\text { furnaces, heaters, } \\
\text { ovens, and dryers }\end{array}$ & $\mathrm{X}$ & Maybe & $\mathrm{X}$ & $\mathrm{X}$ & $X$ & $\mathrm{X}$ & Maybe \\
\hline 4 & $\begin{array}{l}\text { Other heating } \\
\text { systems (e.g., } \\
\text { thermal oxidizers, } \\
\text { evaporators, } \\
\text { distillation } \\
\text { columns, ladle } \\
\text { heaters) }\end{array}$ & $\mathrm{X}$ & Maybe & $\mathrm{X}$ & & Maybe & $\mathrm{X}$ & $\mathrm{X}$ \\
\hline 5 & $\begin{array}{l}\text { Power generation } \\
\text { equipment such as } \\
\text { combustion } \\
\text { turbines, steam } \\
\text { turbines, and } \\
\text { internal } \\
\text { combustion } \\
\text { engines }\end{array}$ & $\mathrm{X}$ & & $\mathrm{X}$ & & & $X$ & $X$ \\
\hline 6 & $\begin{array}{l}\text { Prime movers such } \\
\text { as fuel fired } \\
\text { internal } \\
\text { combustion } \\
\text { engines to drive } \\
\text { compressors, and } \\
\text { pumps }\end{array}$ & $\mathrm{X}$ & Maybe & $X$ & & & Maybe & \\
\hline 7 & $\begin{array}{l}\text { Compressed air or } \\
\text { gas systems that } \\
\text { use intercoolers or } \\
\text { after-coolers }\end{array}$ & $\mathrm{X}$ & & $\mathrm{X}$ & & & & \\
\hline 8 & $\begin{array}{l}\text { Building heating } \\
\text { and cooling } \\
\text { (HVAC) systems }\end{array}$ & $\mathrm{X}$ & & $\mathrm{X}$ & & & & \\
\hline
\end{tabular}

Source: Arvind Thekdi (E3M, Inc.) 
Table 2-3. Summary of types of low- and ultralow-temperature heat from different industries.

\begin{tabular}{|c|c|c|c|c|c|c|c|c|c|c|c|c|}
\hline $\begin{array}{c}\text { Low-temperature waste heat } \\
\text { source }\end{array}$ & Steel & Al. & Glass & Paper & \begin{tabular}{|c|} 
Pet. \\
refining
\end{tabular} & Mining & Chemical & Food & Cement & Coating & $\begin{array}{c}\text { Steam } \\
\text { gen. }\end{array}$ & CHP \\
\hline \multicolumn{13}{|l|}{$\begin{array}{l}\text { 1. The exhaust gases or } \\
\text { vapors }\end{array}$} \\
\hline $\begin{array}{l}\text { 1a. Low-temperature } \\
\text { combustion products (low } \mathrm{O}_{2} \\
\text { content)_clean }\end{array}$ & $\mathrm{L}$ & $\mathrm{L}$ & $\mathrm{L}$ & & $\mathrm{L}$ & & $\mathrm{L}$ & UL & & $\mathrm{L}$ & $\mathrm{L}$ & \\
\hline $\begin{array}{l}\text { lb. Low-temperature flue } \\
\text { gases or combustion products } \\
\text { (low } \mathrm{O}_{2} \text { content) with } \\
\text { contaminants }\end{array}$ & & & & & & & & & & $\mathrm{L}$ & $\mathrm{L}$ & \\
\hline $\begin{array}{l}\text { 1c. Heated air or flue gases } \\
\text { containing high }(>14 \%) \mathrm{O}_{2} \\
\text { without a large amount of } \\
\text { moisture and particulates }\end{array}$ & & & & UL & & UL & $\mathrm{L}$ & UL & $\mathrm{L}$ & & & $\mathrm{L}$ \\
\hline $\begin{array}{l}\text { 1d. Process gases or by- } \\
\text { product gases/vapors that } \\
\text { contain combustibles }\end{array}$ & & & & & UL & & $\mathrm{L}$ & & & & & \\
\hline $\begin{array}{l}\text { le. Process or makeup air } \\
\text { mixed with combustion } \\
\text { products, large amount of } \\
\text { water vapor or moisture }\end{array}$ & & & & UL & & & & $\mathrm{L}$ & & & & \\
\hline $\begin{array}{l}\text { 1f. Steam discharged as vented } \\
\text { steam or steam leaks }\end{array}$ & $\mathrm{L}$ & & & $\mathrm{L}$ & $\mathrm{L}$ & & $\mathrm{L}$ & $\mathrm{L}$ & & & $\mathrm{L}$ & $\mathrm{L}$ \\
\hline \multicolumn{13}{|l|}{ 1g. Other gaseous streams } \\
\hline \multicolumn{13}{|l|}{ 2. Heated water or liquids } \\
\hline $\begin{array}{l}\text { 2a. Clean heated water } \\
\text { discharged from indirect } \\
\text { cooling systems }\end{array}$ & UL & & & & & & UL & & & & UL & UL \\
\hline $\begin{array}{l}2 \mathrm{~b} \text {. Hot water that contains } \\
\text { presence of large amount of } \\
\text { separatable solids }\end{array}$ & UL & & & UL & & UL & UL & UL & & & & \\
\hline \multicolumn{13}{|l|}{ 3. Hot products } \\
\hline $\begin{array}{l}\text { 3a. Hot solids that are air- } \\
\text { cooled after processing }\end{array}$ & $\mathrm{L}$ & $\mathrm{L}$ & $\mathrm{L}$ & UL & $\mathrm{L}$ & UL & $\mathrm{L}$ & UL & $\mathrm{L}$ & UL & & \\
\hline $\begin{array}{l}3 \mathrm{~b} . \text { Hot liquids/vapors that are } \\
\text { cooled after thermal processing }\end{array}$ & & & & $\mathrm{L}$ & & & $\mathrm{L}$ & $\mathrm{L}$ & & & & \\
\hline \multicolumn{13}{|l|}{ 4. High-temperature surfaces } \\
\hline 4a. Furnace or heater walls & UL & UL & $\mathrm{L}$ & & UL & & UL & & $\mathrm{L}$ & & & \\
\hline $\begin{array}{l}\text { 4b. Extended surfaces or parts } \\
\text { used in furnaces or heaters }\end{array}$ & UL & UL & UL & & UL & & UL & & & & & \\
\hline
\end{tabular}

L: low temperature $\left(250^{\circ} \mathrm{F}-450^{\circ} \mathrm{F}\right)$, UL: ultralow temperature $\left(<250^{\circ} \mathrm{F}\right)$, Source: Arvind Thekdi (E3M, Inc.)

\subsection{LOW-TEMPERATURE WASTE HEAT AVAILABILITY}

Waste heat from manufacturing plants is discharged in a broad temperature range as shown in Table 2-1. Most of this waste heat is in the form of exhaust or flue gases, or steam and condensate from heating equipment and processes. Two major reports have studied low-temperature waste heat availability, estimating low-temperature waste heat to be approximately $53 \%{ }^{1}$ and $61 \%^{2}$ of the total unrecovered waste heat. The estimates presented by these reports are different because of the different assumptions such as reference temperatures and energy users. 
The source suggesting $61 \%$ is from a 2008 BCS report. This report analyzed industrial processes using a large amount of energy and reported estimates of waste heat in low-, medium-, and high-temperature ranges. Unrecovered waste heat availability was reported at reference temperatures of $77^{\circ} \mathrm{F}$ and $300^{\circ} \mathrm{F}$. Total recoverable low-temperature waste heat, defined as $450^{\circ} \mathrm{F}$ and lower, accounted for approximately $908 \mathrm{TBtu} /$ year (using $77^{\circ} \mathrm{F}$ as a reference temperature). This is based on the total unrecovered waste heat of $1,478 \mathrm{TBtu} / \mathrm{year}$, and the low-temperature waste heat being about $61 \%$ of the total unrecovered waste heat.

The other source (prepared by ICF International) ${ }^{1}$ gives values of low-temperature waste heat as 570 $\mathrm{TBtu} /$ year for temperatures lower than $300^{\circ} \mathrm{F}$ and $612 \mathrm{TBtu} /$ year for temperatures between $300^{\circ} \mathrm{F}$ and $450^{\circ} \mathrm{F}$, totaling to $1,182 \mathrm{TBtu} /$ year for low temperature as defined in this report. This heat represents $53 \%$ of the estimated total waste heat available $(2,240 \mathrm{TBtu} / \mathrm{year})$. The ICF report used $120^{\circ} \mathrm{F}$ as reference temperature, possibly contributing to the higher total waste heat estimate than reported by the BCS report. Additionally, the BCS report included only the major energy user sectors and not all industrial sectors.

Additionally, it is unclear if either of the references accounted for residual or secondary low-temperature heat. The recovery of medium- and high-temperature waste heat usually results in the production of lower temperature streams due to economical or thermodynamic limitations of the heat recovery equipment used. This low-temperature waste heat stream is usually not used and is discharged into the atmosphere.

Table 2-4, as taken from the ICF report, shows waste heat sources from different industries and the energy content of the waste heat by temperature ranges. This table includes all manufacturing sectors (NAICS 311 to 339) reported in Manufacturing Energy Consumption Survey (MECS) report published by the US Energy Information Administration (EIA) of DOE. Assuming that the secondary waste heat is not included in the low-temperature waste heat values shown in Table 2-4, these values were used to estimate the total amount of low-temperature waste heat generated (as shown in Table 2-5). An average heat recovery equipment effectiveness or capability of high-temperature WHR systems is assumed to be 60\%, meaning the remaining $40 \%$ is still available as low-temperature heat. Based on this assumption, the total additional low-temperature heat as secondary waste heat can be $425 \mathrm{TBtu} / \mathrm{year}(370.4+54.4 \mathrm{TBtu} / \mathrm{yr})$. Accounting for this heat, the total amount of estimated low-temperature waste heat is about $1,600 \mathrm{TBtu} / \mathrm{year}$, or $71.6 \%$. of the total reported in Table 2.4 .

Table 2-4. Waste heat sources and temperature ranges.

\begin{tabular}{|l|c|c|c|r|r|}
\hline \multirow{2}{*}{\multicolumn{1}{|c|}{ Industry }} & \multicolumn{5}{|c|}{ Energy content (TBtu/yr) by temperature* } \\
\cline { 2 - 6 } & $\mathbf{< 3 0 0}^{\circ} \mathbf{F}$ & $\mathbf{3 0 0}^{\circ} \mathbf{F}-\mathbf{4 5 0}^{\circ} \mathbf{F}$ & $\mathbf{4 5 0}^{\circ} \mathbf{F}-\mathbf{1 , 2 0 0}^{\circ} \mathbf{F}$ & $\mathbf{> 1 , 2 0 0}^{\circ} \mathbf{F}$ & $\begin{array}{c}\text { Total } \\
(\mathbf{T B t u} / \mathbf{y r})\end{array}$ \\
\hline 311: Food manufacturing & 3.70 & 28.30 & 19.20 & - & $\mathbf{5 1 . 2 0}$ \\
\hline $\begin{array}{l}\text { 312: Beverage and tobacco product } \\
\text { manufacturing }\end{array}$ & 0.20 & 1.60 & 0.20 & - & $\mathbf{2 . 0 0}$ \\
\hline 313: Textile mills & 10.30 & 1.90 & 0.40 & - & $\mathbf{1 2 . 6 0}$ \\
\hline 314: Textile product mills & - & - & - & - & $\mathbf{0 . 0 0}$ \\
\hline 315: Apparel manufacturing & 1.10 & - & - & - & $\mathbf{1 . 1 0}$ \\
\hline $\begin{array}{l}\text { 316: Leather and allied product } \\
\text { manufacturing }\end{array}$ & - & & & & $\mathbf{0 . 0 0}$ \\
\hline 321: Wood product manufacturing & 46.80 & 42.80 & 4.40 & - & $\mathbf{9 4 . 0 0}$ \\
\hline 322: Paper manufacturing & 50.30 & 97.00 & 5.30 & - & $\mathbf{1 5 2 . 6 0}$ \\
\hline 323: Printing and related support activities & 15.50 & 3.20 & 3.40 & 1.10 & $\mathbf{2 3 . 2 0}$ \\
\hline $\begin{array}{l}\text { 324: Petroleum and coal products } \\
\text { manufacturing }\end{array}$ & 86.40 & 114.20 & 658.10 & 5.60 & $\mathbf{8 6 4 . 3 0}$ \\
\hline
\end{tabular}




\begin{tabular}{|l|c|c|c|c|r|}
\hline \multirow{2}{*}{ Industry } & \multicolumn{5}{|c|}{ Energy content (TBtu/yr) by temperature* } \\
\cline { 2 - 6 } & $\mathbf{< 3 0 0}^{\circ} \mathbf{F}$ & $\mathbf{3 0 0}^{\circ} \mathbf{F}-\mathbf{4 5 0}^{\circ} \mathbf{F}$ & $\mathbf{4 5 0}^{\circ} \mathbf{F}-\mathbf{1 , 2 0 0} \mathbf{~}^{\circ} \mathbf{F}$ & $\mathbf{> 1 , 2 0 0}^{\circ} \mathbf{F}$ & $\begin{array}{c}\text { Total } \\
(\mathbf{T B t u} / \mathbf{y r})\end{array}$ \\
\hline 325: Chemical manufacturing & 112.80 & 80.40 & 108.30 & 22.90 & $\mathbf{3 2 4 . 4 0}$ \\
\hline $\begin{array}{l}\text { 326: Plastic and rubber products } \\
\text { manufacturing }\end{array}$ & 7.90 & 2.40 & 0.60 & 0.50 & $\mathbf{1 1 . 4 0}$ \\
\hline $\begin{array}{l}\text { 327: Nonmetallic mineral product } \\
\text { manufacturing }\end{array}$ & 19.50 & 48.10 & 105.70 & 18.90 & $\mathbf{1 9 2 . 2 0}$ \\
\hline 331: Primary metal manufacturing & 142.70 & 56.80 & 7.20 & 87.20 & $\mathbf{2 9 3 . 9 0}$ \\
\hline $\begin{array}{l}\text { 332: Fabricated metal product } \\
\text { manufacturing }\end{array}$ & 49.50 & 114.80 & 9.80 & - & $\mathbf{1 7 4 . 1 0}$ \\
\hline 333: Machinery manufacturing & 7.40 & 5.70 & 1.30 & - & $\mathbf{1 4 . 4 0}$ \\
\hline $\begin{array}{l}\text { 334: Computer and electronic product } \\
\text { manufacturing }\end{array}$ & 3.10 & 2.20 & - & - & $\mathbf{5 . 3 0}$ \\
\hline 335: Electrical equipment manufacturing & 2.00 & 1.40 & 0.30 & & $\mathbf{3 . 7 0}$ \\
\hline $\begin{array}{l}\text { 336: } \text { Transportation equipment } \\
\text { manufacturing }\end{array}$ & 6.20 & 7.40 & 1.10 & - & $\mathbf{1 4 . 7 0}$ \\
\hline $\begin{array}{l}\text { 337: Furniture and related product } \\
\text { manufacturing }\end{array}$ & 2.10 & 1.90 & 0.50 & 0.10 & $\mathbf{4 . 6 0}$ \\
\hline 339: Miscellaneous manufacturing & 2.10 & 2.00 & 0.50 & 0.10 & $\mathbf{4 . 7 0}$ \\
\hline Total energy content (TBtu/yr) & $\mathbf{5 7 0}$ & $\mathbf{6 1 2}$ & $\mathbf{9 2 6}$ & $\mathbf{1 3 6}$ & $\mathbf{2 , 2 4 4}$ \\
\hline
\end{tabular}

* Reference temperature of $120^{\circ} \mathrm{F}$

Table 2-5. Estimated additional low-temperature waste heat.

\begin{tabular}{|l|r|r|r|r|r|}
\cline { 2 - 6 } \multicolumn{1}{c|}{} & \multicolumn{5}{c|}{ Energy content (TBtu/yr) by temperature range } \\
\cline { 2 - 6 } \multicolumn{1}{c|}{} & $\mathbf{< 0 0}{ }^{\circ} \mathbf{F}$ & $\mathbf{3 0 0}^{\circ} \mathbf{F}-\mathbf{4 5 0}^{\circ} \mathbf{F}$ & $\mathbf{4 5 0}^{\circ} \mathbf{F}-\mathbf{1 , 2 0 0}^{\circ} \mathbf{F}$ & $\mathbf{> 1 , 2 0 0}^{\circ} \mathbf{F}$ & $\begin{array}{c}\text { Total } \\
(\mathbf{T B t u} / \mathbf{y r})\end{array}$ \\
\hline Waste heat (TBtu/year) & 570 & 612 & 926 & 136 & $\mathbf{2 , 2 4 4}$ \\
\hline Percentage at lower temperature & $100 \%$ & $100 \%$ & $40 \%$ & $40 \%$ & $\mathbf{5 4}$ \\
\hline Low-temperature heat & 570 & 612 & 370 & $\mathbf{1 , 6 0 6}$ \\
\hline Low-temperature heat as a percentage of total waste heat & & $\mathbf{7 1 . 6 \%}$ \\
\hline
\end{tabular}

\section{Alternate Analyses}

The described estimates of low-temperature waste heat were supplemented with two approaches. One was based on process information, termed "bottom-up analysis," and included analysis of commonly used thermal processes in manufacturing and their operating data, specifically operating temperatures. The second approach, termed "top-down analysis," was based on extensive energy use data available from EIA in the form of the 2010 MECS. ${ }^{8}$

\section{Bottom-Up Analysis}

In this approach, a list of commonly used industrial heating processes was developed and arranged by NAICS code so they could be associated with specific industries in 3- to 5-digit format. The list includes data such as the process name, NAICS code, type of waste heat, operating temperature range (higher and lower) for the process, and type of energy used (see Appendix A for the full list). For each process information such as process and flue gas exit temperature, type of energy used, and estimated flue gas 
analysis (e.g., particularly oxygen content, moisture content of flue gases) can be used to calculate available heat (percentage of heat remaining in the process system) and flue gas loss as a percentage of the total heat input of the process. This gives us magnitude of waste heat per unit of heat input. However, total quantity or magnitude of waste heat cannot be calculated without knowledge of total energy use or heat energy input data, which could not be obtained at this time. MECS data cannot be directly applied to determine energy use for specific processes, even when such data is available for 5-digit NAICS codes. Therefore, we decided to take a second approach that allows the use of MECS data to get information on total energy use for the processes under consideration and apply the exhaust gas heat loss.

The above calculations consider only the recoverable heat from flue gases as practiced by the industry at this time. It does not consider possible recovery from other waste heat sources such as wall loss, opening loss, heat content of hot material discharged from a heating equipment, cooling systems (where used) etc. In most cases the heat loss (except heat content of the heated or processed material) is less than $5 \%$ of the total heat input. Some of the exceptions where the surface or skin heat loss exceed 5\% include cement kilns, glass melting furnaces, liquid metal handling equipment (ladles) etc. None of the reports cited for waste heat sources and recovery (BCS and ICF) consider these waste heat sources.

\section{Top-Down Analysis}

This approach, based on the $\mathrm{MECS}^{8}$ report, uses energy consumption values for many manufacturing plants reported in 3- to 5-digit NAICS codes. The analysis, given in Appendix B, is based on energy use data contained in the 2013 edition of the MECS report, which uses data collected in 2010 from manufacturing plants. The report provides energy use in manufacturing in various categories:

1. Conventional boiler energy use

2. CHP and/or cogeneration process

3. Process heating

4. Other

After reviewing each manufacturing area that had energy use data (available for NAICS 311 to 339, ranging from 3- to 5-digit levels of specification), we estimated the quantity of low-temperature waste heat for each of the four categories. This estimate was based on thermal process operating parameters, particularly the exhaust gas temperature and presence of excess air, moisture, or other heat-carrying materials (i.e., combustible gases), which can be used to calculate approximate available heat. The value of available heat was used to calculate waste heat loss as a percentage of the total energy used for the first three categories.

1. For conventional boilers, an average flue gas temperature of $400^{\circ} \mathrm{F}$ with $2 \%$ to $4 \%$ oxygen (dry basis) was used. This provides an average available heat of approximately $82.5 \%$. The waste heat $(100 \%-$ $82.5 \%$ ) is then $17.5 \%$ of the heat used for the boilers. This is a broad assumption but is reasonably valid for a quick analysis.

2. For CHP, there are at least three options: CHP using a high-pressure steam boiler with the use of a steam turbine generator system; use of a combustion turbine followed by an HRSG; and use of reciprocating engines for production of power with heat recovery in the form of hot water or steam generation. Out of these three options, the first two are the most prevalent in manufacturing plants. Once again, we assumed that these boilers or HRSG units discharge waste heat at about $350^{\circ} \mathrm{F}$ with $4 \%$ to $6 \%$ oxygen in flue gases resulting in available heat of $82.5 \%$ or heat loss of $17.5 \%$ of the boiler-HRSG heat input. 
3. For the process heating category, energy use for each NAICS sector was individually evaluated for exhaust gas temperature range and flue gas analysis that can be used to estimate available heat and hence the energy loss. This was a very qualitative approach based on the author's (Arvind Thekdi's) experience as well as review of available data such as (i) type of equipment used (e.g., furnace, heater, oven dryer), (ii) presence of excess air used for safety concerns as in the case of drying ovens, (iii) presence of water vapor that will reduce available heat and increase waste heat, and (iv) use of a heat recovery device such a convection section. Available heat values were derived by using available heat calculators and verified by using a reference commonly used by the equipment designers and users. $^{9}$

4. Waste heat discharged from reciprocating engines and other prime movers was not accounted for. Although some of these engines may have been accounted for under CHP equipment, prime movers can also drive compressors, pumps, and other process equipment, and waste heat from these units is difficult to estimate.

5. The most difficult decision was related to the use of a category listed as "Other" in the MECS report. Much of this can be energy used in the form of by-product energy sources (by-product gases produced in chemical, petroleum, and steel industries) and other energy sources (waste products used in the forest products sector such as pulp-paper and lumber industry, or bio-fuels). Two cases were analyzed: the "without other" case assumed that none of this energy produces any waste heat and the "with other" case assumed that $10 \%$ of this energy is available as low-temperature waste heat. Although there is no verifiable basis for either one of these assumptions, both values are reported in Table 2-6 to provide an estimated range of low-temperature waste heat.

6. All fired heating systems, including boilers and HRSGs, result in low-temperature waste heat since even the most advanced heat recovery system (economizers, convection heaters, regenerative burners, regenerators, and recuperators) discharge hot gases at minimum of $350^{\circ} \mathrm{F}$ or higher. The calculations assume that each of these waste heat sources is a potential low-temperature waste heat source.

Table 2-6. Estimate of low-temperature waste heat based on top-down analysis.

\begin{tabular}{|l|c|c|}
\hline \multicolumn{3}{|c|}{ Waste heat from manufacturing sector NAICS 311 to 339 } \\
\hline \multicolumn{1}{|c|}{ NAICS range } & Without other* (TBtu/year) & With other* (TBtu/year) \\
\hline 311 to 316 & 156 & 169 \\
\hline 321 to 322 & 133 & 299 \\
\hline 323 to 327 & 603 & 903 \\
\hline 331 to 339 & 192 & 265 \\
\hline Total & $\mathbf{1 , 0 8 4}$ & $\mathbf{1 , 6 3 7}$ \\
\hline
\end{tabular}

*Other refers to energy use category identified as "Other" in MECS report

Comparisons of results from this approach gave a total low-temperature waste heat range between 1,084 and 1,637 TBtu/year compared with the previously reported values from EIA MECS as 1,182 to 1,606 TBtu/year. Considering the assumptions made in the analysis values of usable waste heat, these are comparable. More accurate values could be obtained by a detailed analysis of thermal processes used, heating equipment used, and the process operating parameters used. 


\section{LOW-TEMPERATURE HEAT RECOVERY TECHNOLOGY}

\section{Introduction}

Industry uses many different technologies and associated equipment to recover heat in manufacturing plants. Heat recovery from low-temperature streams can be divided into two categories: (i) conventional and currently used technologies, and (ii) emerging or new technologies. This section discusses conventional or current technologies.

\subsection{HEAT EXCHANGERS}

There are several types of heat exchangers, each designed and sized to meet specific requirements of a process or system. All of them transfer heat from a higher-temperature stream to a lower-temperature fluid stream, which is a common and well-established configuration. Although heat exchangers have been used by industry for many decades, innovation continues with several new designs introduced as modified older designs or designs with added performance enhancement features. Heat exchangers can also recover heat from process streams containing otherwise wasted heat. This section discusses heat exchanger designs and performance related to WHR from process streams or other areas with waste heat. Several type of heat exchangers can be used for WHR. Some of the most common and widely used heat exchangers include the following:

- Shell and tube type heat exchangers

- Plate-and-frame type compact heat exchangers (CHEs)

- Spiral heat exchangers

- Recuperators, which can be considered as a subclass of the above three heat exchangers

- Regenerators for recovery of sensible and latent heat from gases

- Condensing heat exchangers, including noncontact and direct contact designs

- Desiccant-type heat exchangers for gases with water vapor content

The major performance indicator of heat exchangers, "effectiveness" (i.e., efficiency), is defined as the ratio of actual heat transfer rate, $q_{\text {actual }}(\mathrm{Btu} / \mathrm{h})$, to maximum possible heat transfer rate or heat availability $q_{\max }(\mathrm{Btu} / \mathrm{h})$. For a gaseous or liquid medium, these are defined as

$$
\begin{gathered}
q_{\text {actual }}=C_{h} *\left(T_{\text {hout }}-T_{\text {hin }}\right)=C_{c} *\left(T_{\text {cin }}-T_{\text {cout }}\right) \\
q_{\max }=C_{\text {min }} *\left(T_{\text {hin }}-T_{\text {cin }}\right) \\
\in=\frac{q_{\text {actual }}}{q_{\max }}
\end{gathered}
$$

where

$$
\begin{aligned}
& \mathcal{E}=\text { effectiveness (nondimensional) } \\
& \mathrm{T}_{\text {hout }}=\text { temperature of the outgoing hot-side fluid } \\
& \mathrm{T}_{\text {hin }}=\text { temperature of the incoming hot-side fluid } \\
& \mathrm{T}_{\text {cin }}=\text { temperature of the incoming cold-side fluid } \\
& \mathrm{T}_{\text {cout }}=\text { temperature of the outgoing cold-side fluid }
\end{aligned}
$$

$C_{h}$ and $C_{c}$ are total heat capacities of hot and cold fluid, respectively. They are defined as

$C_{h}=m_{h} * c_{p h}$ and $C_{c}=m_{c} * c_{p c}$ 
$\mathrm{m}_{\mathrm{h}}=$ mass flow rate $(\mathrm{lbm} / \mathrm{hr})$ of hot fluid

$\mathrm{m}_{\mathrm{c}}=$ mass flow rate $(\mathrm{lbm} / \mathrm{hr})$ of colder fluid

$\mathrm{c}_{\mathrm{ph}}$ and $\mathrm{c}_{\mathrm{pc}}=$ specific heats $\left(\mathrm{Btu} /\left[\mathrm{lbm}-{ }^{\circ} \mathrm{F}\right]\right)$ of hot and cold fluids, respectively

In addition to the effectiveness, several additional operating parameters affect the final selection of the heat exchanger:

- Pressure drop through the heat exchanger on the hot and cold sides of the heat exchanger

- Part load or flow rate performance measured in terms of effectiveness and temperature of the heat exchanger components

- Potential deterioration of performance by contaminants such as the particulates and corrosive fluids

- $\quad$ Ease of cleaning the heat exchangers to maintain its performance

- Initial cost and operations and maintenance (O\&M) cost

\section{Shell and Tube Heat Exchangers}

Shell and tube heat exchangers are the "workhorse" of industries such as the chemical industry, food industry, and petroleum refining industry, and are extensively used for process heat transfer and heat recovery applications. Many suppliers offer shell and tube heat exchangers as a custom unit for a specific application or as a standard design.

A typical shell and tube heat exchanger consists of several tubes contained and sealed in a cylindrical shell. The tubes and shell have various potential configurations and can contain additional heat transfer enhancement devices such as baffles and fins. Figure 3-1 shows two typical designs of shell and tube heat exchangers.

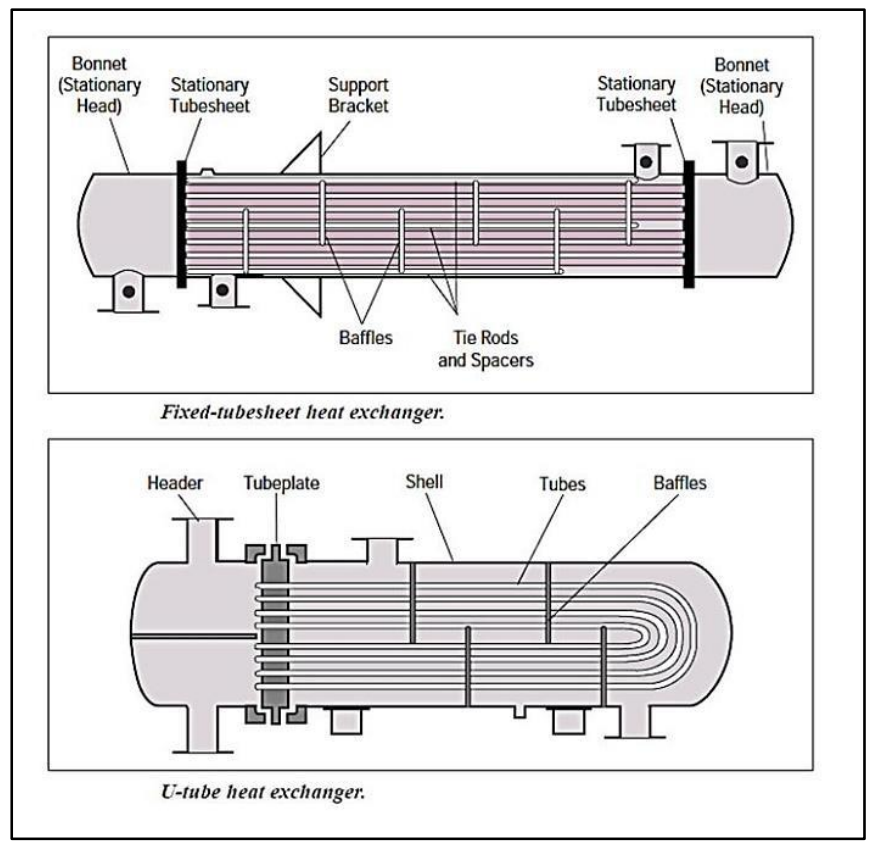

Figure 3-1. Typical single-pass and multiple-pass (U-tube) shell and tube heat exchangers. Courtesy: Chemical Engineering World Blogspot. 
The fixed tube design consists of many tubes that carry one type of fluid (e.g., hot fluid). The shell contains the tubes and the flow of another (cold) type of fluid. The tubes connect to a tube sheet on the front and back sides of the shell to isolate the tube-side fluid from the shell-side fluid. The shell-side (cold) fluid flows into the shell, usually on the exit side of the tubes (hot fluid), to provide counter-current flows that give higher heat transfer rates (see Figure 3-1). The shell may contain baffles, arranged in a variety of configurations, to provide different flow patterns for the shell-side fluid and enhance heat transfer on the shell side. The shell- and tube-side fluids may be at different pressures.

For a U-tube heat exchanger, the tubes are in a U shape. Tube-side fluid entry and exit are on the same side of the heat exchanger using only one header. A tight baffle separates the incoming and exiting tubeside fluid. The shell-side configuration is very similar to the fixed tube sheet design.

Shell and tube heat exchangers offer several advantages over other types of heat exchangers. They can be used for high pressures, with a large pressure differential between the shell side and tube side, simple design, easy maintenance, and proven design used by the industry for many years.

Performance of the heat exchanger, measured in terms of its effectiveness or efficiency, depends on several factors, including the type of fluids (e.g., liquid, gas, condensing vapors, vaporizing liquids), their pressure and temperature, heat exchanger design features such as the tube- and shell-side flow configuration, type and configuration of baffles, and tube-side heat transfer enhancement. Typical shell and tube heat exchangers have an effectiveness of $40 \%$ to $60 \%$.

For waste heat recycling or recovery applications in which the waste heat source (such as lower-pressure steam or vapors) heats higher-pressure liquids (such as water), the waste heat source is introduced on the shell side, and the liquid is passed through the tubes. This configuration is typical for two reasons. The tubes are stronger than the shell, making them more suitable for high-pressure liquids. Additionally, it is easier to clean the tube side than the shell side, keeping the heated products (fluids) cleaner. If the tube side is used to cool waste sources, such as vapors or steam, condensate could form on the inside of the tube, causing flow irregularities and leading to problems with the exchanger.

These heat exchangers, when used for recovering heat from hot gases to heat water or other liquids, have a relatively low effectiveness or efficiency due to a large difference in heat transfer coefficient on the gas side. Heat transfer enhancements can improve effectiveness by using finned tubes and proper placement of baffles (to develop a fluid flow pattern that increases heat transfer) and by promoting vapor condensation on the shell side. The heat exchanger effectiveness is higher when the heat exchanger transfers heat to liquids from other liquids or steam. Then, the heat transfer coefficients on both sides of the heat transfer surface (tubes in this case) can be comparable, resulting in relatively higher overall heat transfer coefficient.

There are several common heat sources and applications for WHR using shell and tube type heat exchangers:

1. Condensates from process steam, distillation processes or refrigeration, and air-conditioning systems

2. Coolants from engines, lubricants, bearings, air compressors, furnace doors, pipes, and grates

3. Flue gas streams and exhaust gas streams from furnaces, dryers, ovens, and boilers and exhaust stacks from fired heating systems

4. Quench oil from heat treating furnaces 
With a few notable exceptions, most low-temperature heat exchangers are constructed from cast iron or copper tubes. The tubes may have aluminum or copper fins pressed in, soldered, or welded on the tubes. Several new features have been incorporated, such as special fin design for finned tube heat exchangers and rendering of tube-on-plate condensers with a Coanda-effect louver design that allows air to flow in waveform. These improvements offer higher heat transfer rates. The advantages and disadvantages of shell and tube heat exchangers are summarized in Table 3-1.

Table 3-1. Advantages and disadvantages of shell and tube heat exchangers.

\begin{tabular}{|l|l|}
\hline \multicolumn{1}{|c|}{ Advantages } & \multicolumn{1}{c|}{ Disadvantages } \\
\hline $\begin{array}{l}\text { Widely known and understood since it is the most } \\
\text { common type }\end{array}$ & $\begin{array}{l}\text { Less thermally efficient than other types of heat transfer } \\
\text { equipment }\end{array}$ \\
\hline $\begin{array}{l}\text { Most versatile compared to other exchangers in terms } \\
\text { of types of service }\end{array}$ & $\begin{array}{l}\text { Subject to flow-induced vibration, which can lead to } \\
\text { equipment failure }\end{array}$ \\
\hline $\begin{array}{l}\text { Widest range of allowable design pressures and } \\
\text { temperatures }\end{array}$ & $\begin{array}{l}\text { Not well suited for temperature cross-conditions } \\
\text { (multiple units in series must be used) }\end{array}$ \\
\hline $\begin{array}{l}\text { Rugged mechanical construction can withstand } \\
\text { substantial physical and process use }\end{array}$ & $\begin{array}{l}\text { Contains stagnant zones (dead zones) on the shell side, } \\
\text { which can lead to corrosion problems }\end{array}$ \\
\hline & $\begin{array}{l}\text { Subject to flow maldistribution, especially with two } \\
\text { phase inlet streams }\end{array}$ \\
\hline
\end{tabular}

\section{Plastic Heat Exchangers}

Metal heat exchangers are subject to corrosion, oxidation, and microbiological attacks. Common chemical water treatments can adversely affect metal heat exchangers, causing slow degradation and loss in heat transfer capacity.

New plastic heat exchanger technology, developed by several suppliers, offers an alternative to metal heat exchangers. The use of specialized plastics for heat exchanger tubing provides effective energy transfer in most applications. Some suppliers claim that the heat transfer capacity of plastic tubing is comparable to that of copper heat exchangers, and that the transfer rate remains consistent for both heating and cooling. These heat exchangers are not subject to corrosion, oxidation, microbiological attacks, or galvanic action, thereby allowing plastic heat exchangers to function effectively under conditions in which conventional systems would not survive. Additionally, friction or contact between coils during operation is not an issue for the plastic for two key reasons: the coils naturally dampen the vibrations in the system, and the tube material surface is smoother, permitting little friction between tubing rows even if they do come in contact. Additionally, plastic is lightweight and the surface of plastic tubing is smoother than copper and resists the buildup of material deposits, which can restrict both fluid and airflow through and around the coils. If an internal buildup does occur, flushing at a moderate pressure can remove buildup from the plastic.

Despite their significant advantages, plastic heat exchangers are not suitable for all applications: they cannot be used for high pressure, for high temperature, or with refrigerants. Plastic is not a suitable heat transfer media for systems with operating temperatures higher than $220^{\circ} \mathrm{F}$ or pressures higher than 150 psi. Finally, plastic cannot be used with any gaseous systems because it does not serve as a sufficient vapor barrier. 


\section{Noncondensing Feed Water Economizers}

Noncondensing feed water economizers, a special class of shell and tube heat exchanger, recover heat from boiler flue gases to preheat boiler feed water. Noncondensing economizers cool combustion products to a temperature at which condensation of water content in flue gases is prevented. Generally, when using noncondensing economizers, sensible heat of water vapor is recovered from flue gas and the boiler efficiency increases by $1 \%$ for every $40^{\circ} \mathrm{F}$ reduction in flue gas temperature. ${ }^{12}$ However, condensation of water vapor in flue gas allows for both sensible and latent heat recovery and provides much larger benefits, often reducing fuel requirements by $5 \%$ to $10 \%$.

Figure 3-2 shows a conventional noncondensing economizer in which boiler flue gases flow around coils containing boiler feed water from a deaerator. There are several designs of the same basic configuration, and in each case, flue gases pass around the water-cooled coils to preheat boiler feed water. The watercooled tubes are finned to enhance gas-side heat transfer and keep the unit size as small as possible. Key considerations for the application of these economizers include sulfur content of the fuel, flue gas temperature, feed water inlet and outlet temperature, and overall effectiveness of the economizers. Sulfur content is critical since below-dew point conditions in the flue result in sulfuric acid formation that could damage or destroy the tubes of the economizer. Therefore, the feed water and flue gas temperatures leaving the economizer are always maintained higher than the flue gas water condensation temperature. The exact temperature that should be maintained depends on the type of fuel used (mainly sulfur content) and excess air used for the combustion. Figure 3-3 shows the recommended minimum feed water temperature leaving the economizer (i.e., the acid dew point) for various sulfur content in the fuel. ${ }^{5}$ Maintaining the feed water and flue gas temperatures above a certain minimum value will help keep the tube and interior parts of the economizer (heat exchanger) above certain temperatures and avoid acid condensation inside the economizer itself.

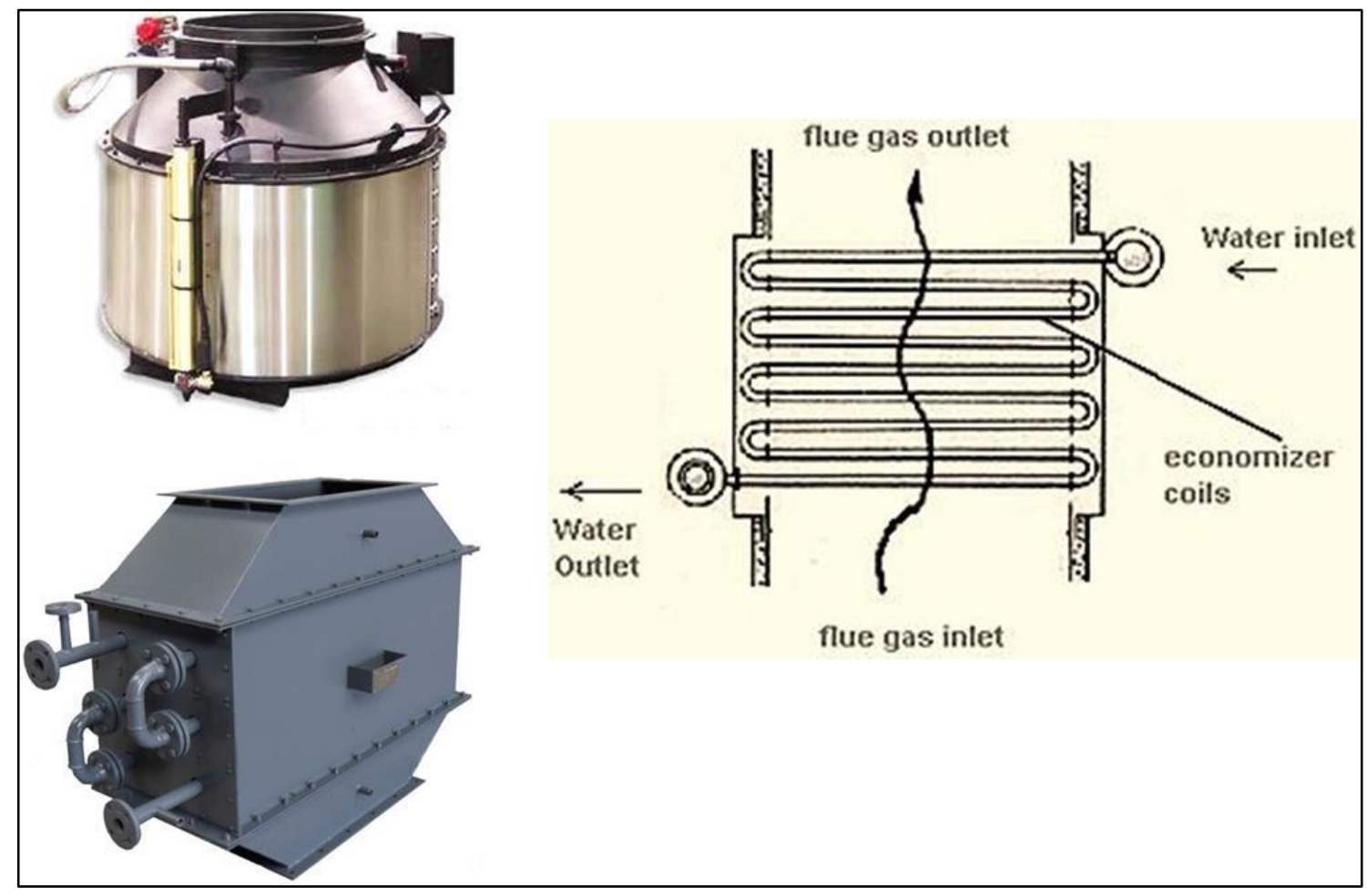

Figure 3-2. Conventional noncondensing feed water economizer. 


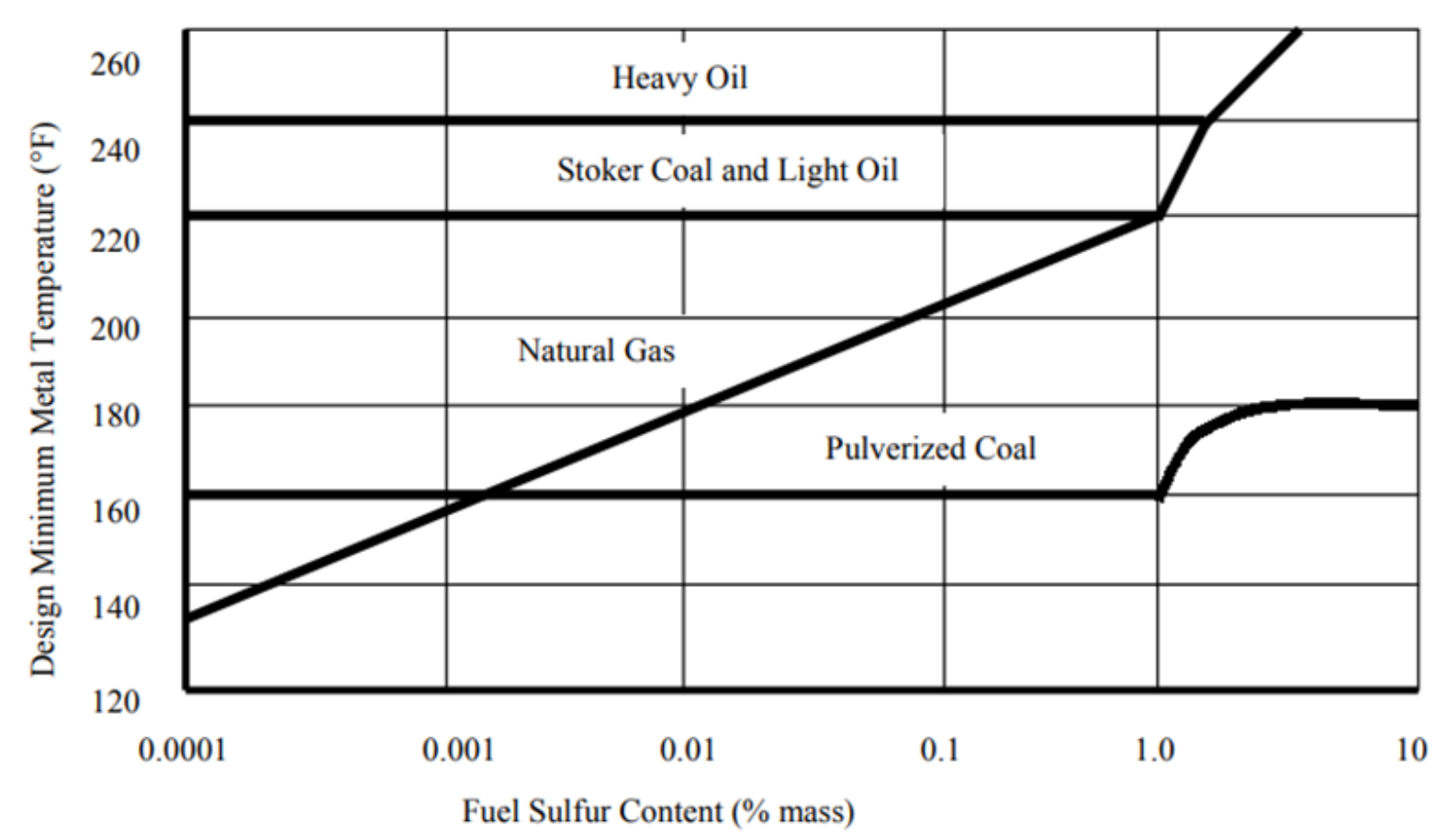

Figure 3-3. Feed water economizer minimum metal temperature requirement to avoid acid condensation.

Similar to other shell and tube heat exchangers, noncondensing economizers have many different configurations, but all of them have feed water flowing inside the tubes while the gas flows outside the tubes. The gas-water flow is counter-current (i.e., cross-flow), so the heated water discharges at the hightemperature gases side and the gases travel along the economizer tubes and discharge at the colder tube side. Because any condensation will take place at the gas exit, the tube outside temperature and any part of the shell interior temperature must be kept above the acid dew point (about $140^{\circ} \mathrm{F}$ for natural gas flue products). Finally, a soot blowing arrangement must be used to keep the water tube surfaces clean for economizers used in systems that use fuels such as coal, bio-fuels, and solid or liquid waste fuels.

\section{Condensing Economizers}

Noncondensing economizers avoid cooling the flue gases to the water vapor dew point, thereby recovering only the sensible heat contained in the flue gases. Condensing economizers, however, are designed to cool flue gases below water condensation temperature and can recover both the sensible and latent heat from the flue gas products. Stoichiometrically, every pound of natural gas combusted produces $2.25 \mathrm{lb}$ of water vapor; this not only represents a significant amount of latent heat energy, but also a significant amount of water that can be recovered. Advancements in materials, metallurgy, and heat recovery methodology now allow for the recovery of this energy and the realization of fuel cost savings.

Figure 3-4 illustrates the increased rate of heat transfer and efficiency increase once the heat recovery process enters the latent recovery zone for natural gas fuel (commonly used in North America). ${ }^{17}$ The red portion of the heat transfer curve represents the sensible heat transfer rate as it relates to the exit flue gas temperature; the blue portion of the curve represents the sensible and latent heat transfer rate. The heat transfer rate increases exponentially once the heat transfer includes latent heat energy recovery. The pink dotted line illustrates the potential increase in efficiency from decreasing the flue gas exit temperature from the normal $450^{\circ} \mathrm{F}$ to $105^{\circ} \mathrm{F}$. Decreasing the exit temperature allows for the operating efficiency of the fired equipment (e.g., boilers) to increase from $80 \%$ to $95 \%$. These values are based on a higher heating value. 


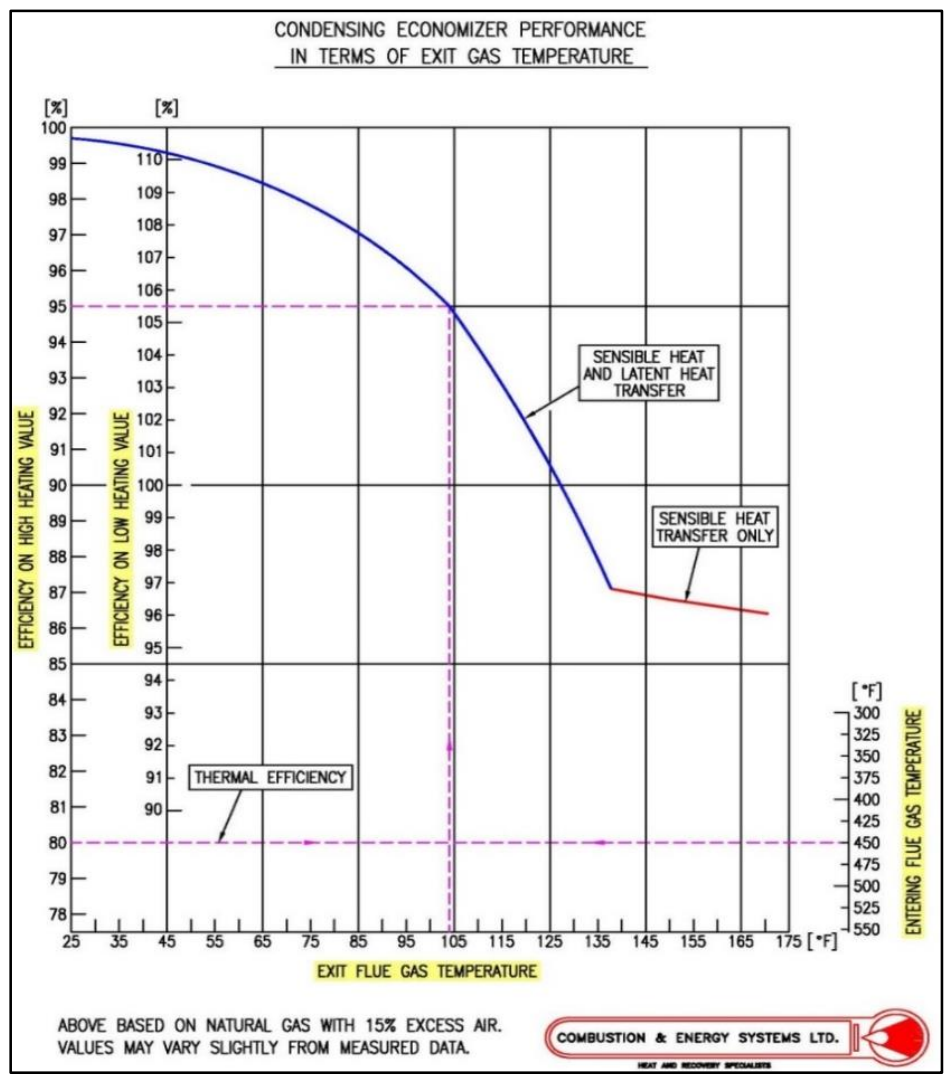

Figure 3-4. Heat recovery by lowering flue gas temperature using a condensing heat exchanger. Courtesy: Combustion and Energy Systems, Ltd.

Noncontact and contact heat exchangers are the two types of condensing heat exchangers used by the industry. In the noncontact design, the flue gases are separated from feed water, similar to previously discussed economizers, and a separate heat exchanger is often used after a conventional economizer or heat exchanger. In the contact-type condensing economizer, the flue gases come in direct contact with the feed water or other type of water to cool the gases to a very low temperature and recover a large percentage of the latent heat. These are further discussed in the next section.

Figure 3-5 shows a typical noncontact condensing economizer system setup for recovering latent heat from a package boiler. The traditional economizer (a noncondensing heat exchanger) recovers the sensible heat of flue gases and exit gases feed into a noncontact condensing heat exchanger. The noncontact condensing heat exchanger is specially designed to use corrosive resistant materials because of the acidic condensate from flue gas (e.g., stainless steel and specially coated carbon steel). The heat exchanger includes a water drain and collection arrangement on the flue gas side. The cold makeup water is uncontaminated, and it is heated to a higher temperature in a conventional economizer for boiler feed water. 


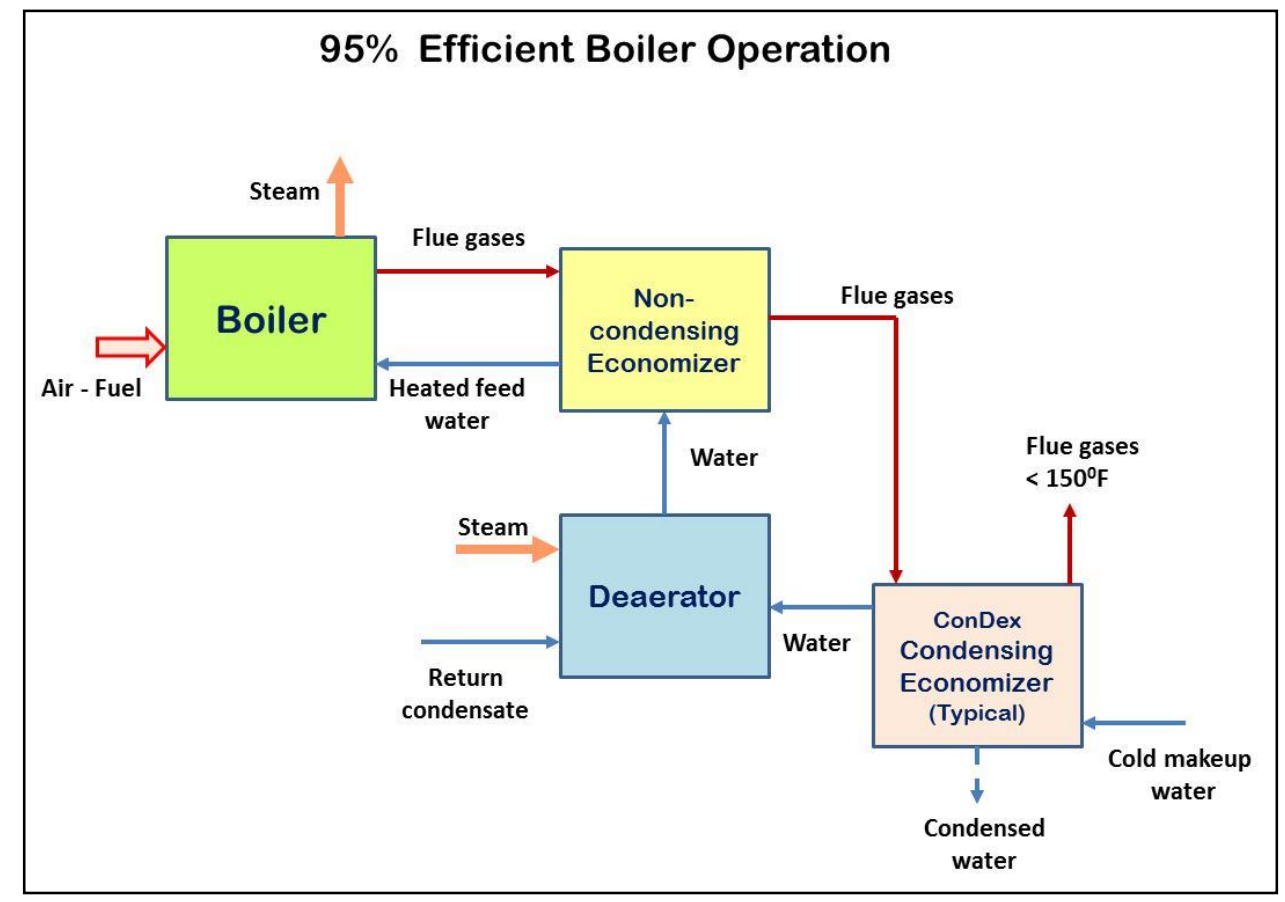

Figure 3-5. Use of a condensing heat exchanger to increase boiler efficiency.

The same schematic applies to single or multiple boilers; for multiple-boiler or other heat source applications, a single unit will tie into all the boiler stacks, combine the flue gas flows, and recycle the heat into the process fluid or loop that requires heat. A typical system will have the two economizers installed in series, with a bypass to divert gases from the noncondensing (conventional) economizer directly to the stack in case the condensing economizer needs to be isolated. An installation of a noncontact condensing economizer at a chemical plant is shown in Figure 3-6.
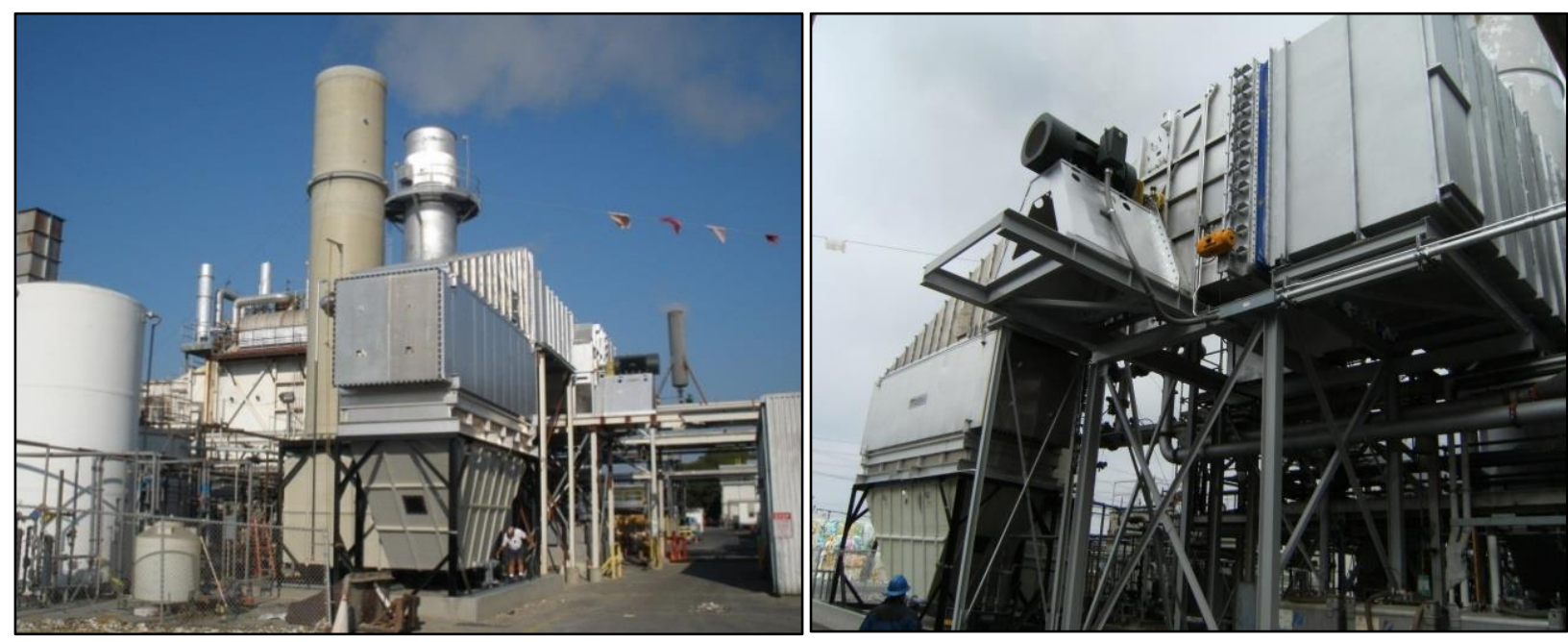

Figure 3-6: Installation of a noncontact condensing economizer at a chemical plant. Courtesy: Combustion and Energy Systems, Ltd.

The noncontact condensing economizer unit design is very similar to a shell and tube heat exchanger with the tube and shell material selected to withstand acidic environments. The following list provides general guidelines for material selection, though variations from these materials may be substantial. 
- Tubes: stainless steel, similar to grade 316 or better

- Fins for the tubes: aluminum bonded to the tubes

- Feed water headers: carbon steel for the makeup or process water; typically, the headers are fabricated from 304 stainless steel

- All surfaces in contact with makeup or process water usually made from stainless steel; the shell where acidic gases and condensate is present is fabricated using stainless steel, usually 304 or equivalent

Overall, economics and payback period for the installation of a noncontact condensing economizer depend on the cost of fuel, size of the installation, and location of the installed system. Based on installations at several locations, as per the supplier, ${ }^{18}$ the payback period can vary from less than 8 months to 2 years, assuming a natural gas cost of $\$ 8.00$ per MMBtu. The use of a condensing economizer is most rewarding when the makeup water temperature is low all year, as in the case of colder climate regions.

\section{Direct Contact Economizers}

A direct contact heat exchanger, sometimes referred to as a "boiler stack economizer," is a special class of heat exchanger that is different from conventional heat exchangers. In this unit, flue gases come into direct contact with water and transfer heat to the water while recovering sensible and latent heat content. Figure 3-7 illustrates a typical arrangement for a direct contact condensing heat exchanger.

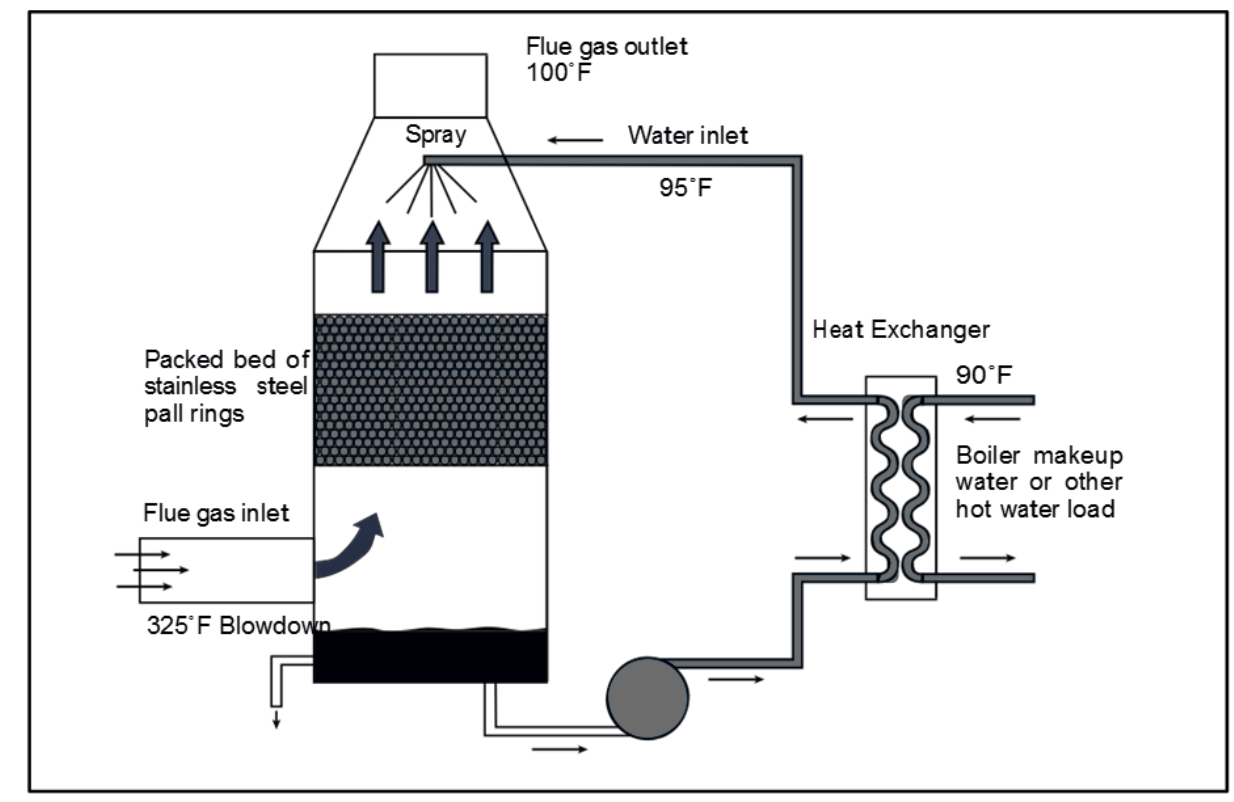

Figure 3-7. A direct contact condensing heat exchanger.

The direct contact condensing economizer consists of a vapor-conditioning chamber followed by a countercurrent spray chamber. In the spray chamber, small droplets of water come into direct contact with the hot flue gas, providing a non-fouling heat transfer surface. The water droplets cool the stack gas, condensing the flue gas water vapor content. The spray chamber may be equipped with packing to improve contact between the water spray and hot flue gas. A mist eliminator is required to prevent 
carryover of small droplets. The direct contact design offers a high heat transfer coupled with a water recovery capability since the heated water can be collected for heating boiler feed water, space heating, or other plant process needs, if suitable. Recovered water will be acidic and may require treatment, such as membrane technology, external heat exchangers, $\mathrm{pH}$ control, or water filtration (if a fuel other than natural gas was used) prior to use. In cases in which the heated water is used to heat another stream, such as makeup water, it is necessary to install a secondary water-to-water heat exchanger to transfer heat from the first stream (acidic hot water) to the secondary stream (makeup water) as shown in Figure 3-7. The materials consideration for this unit are very similar to those discussed for a noncontact condensing heat exchanger from the previous section.

Heat recovery performance of a direct contact heat exchanger depends on the incoming water temperature, a typical unit can drop the flue gas temperature to $5^{\circ} \mathrm{F}$ to $10^{\circ} \mathrm{F}$ above the inlet water temperature. This allows recovery of a large percentage of the flue gas heat content. In most cases, the flue gas inlet temperature can be very high and the unit can be used without a conventional economizer. However, too high of an inlet water temperature will result in a higher exit temperature for gases, now saturated with water vapor and thus still containing a large amount of latent heat to recover. The direct contact heat exchanger offers a very high efficiency, up to 100\% (based on higher heating value), and potential for boiler efficiency improvement of up to $20 \%$ due to a very low final flue gas temperature.

Direct contact heat exchangers can recover heat from exhaust gases from many types of heating equipment such as boilers, ovens, heaters, and dryers. In most applications, the entering flue gas temperature should be kept low enough to avoid boiling the water produced by the unit. The normal range has been from $150^{\circ} \mathrm{F}$ to $450^{\circ} \mathrm{F}$. Typical payback period for installation of a direct contact heat exchanger varies from 2 to 4 years. Figure 3-8 shows an installation of a roof-mounted direct contact heat exchanger on a small $200 \mathrm{HP}$ boiler that uses the heat of flue gases to heat water for processes.

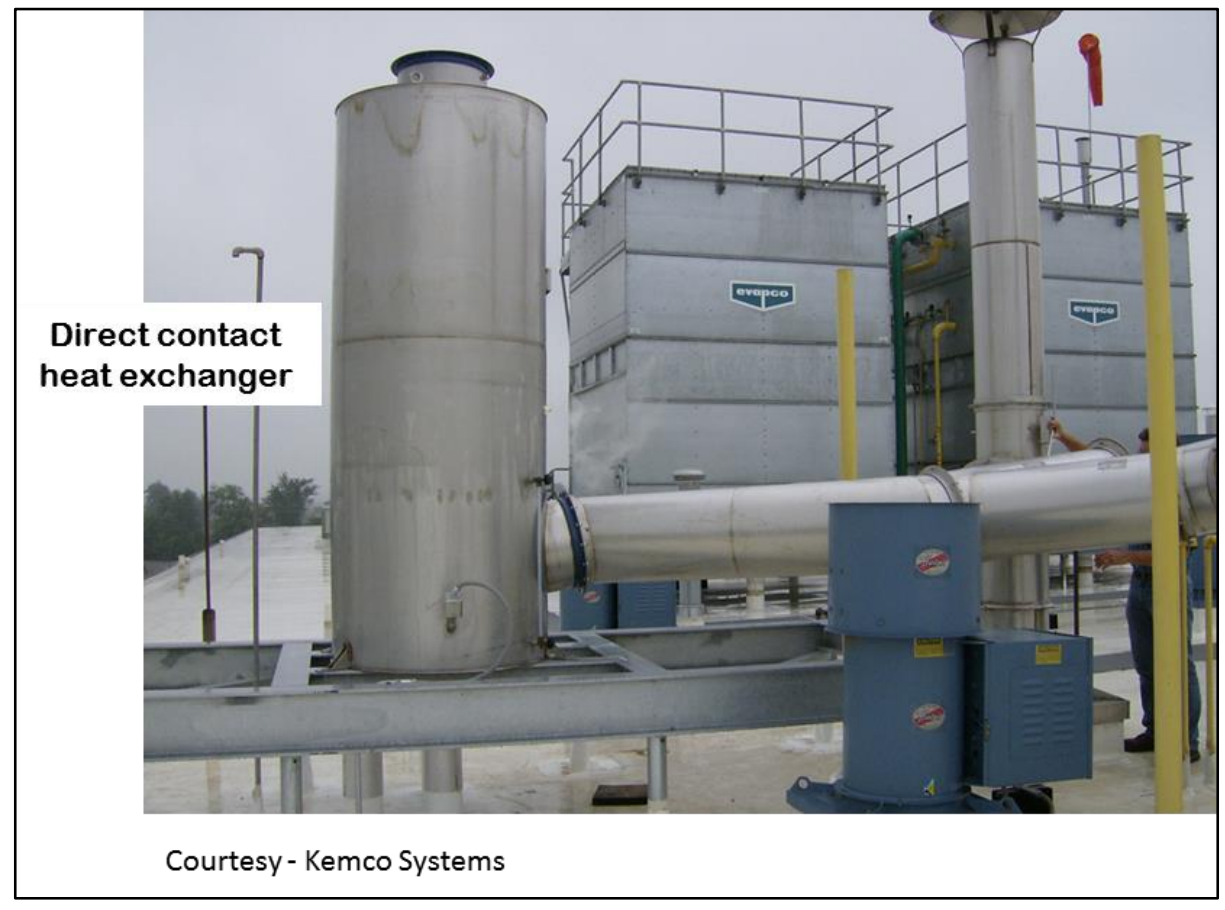

Figure 3-8. Installation of a direct contact condensing heat exchanger on a boiler.

The advantages in using a direct contact heat exchanger include the following: 
- Lack of surfaces to corrode, foul, or otherwise degrade the heat transfer performance

- Potentially superior heat transfer for a given volume of heat exchanger due to the larger heat transfer surface area achievable and the ability to transfer heat at much lower temperature differences between the two streams

- Much lower pressure drop associated with direct contactors compared with their tubular counterparts

- Relatively lower capital cost compared to non-contact designs; direct contact heat exchangers can be constructed out of little more than a pressure vessel, inlet nozzles for the fluid streams, and exit ports

Some of the disadvantages of direct contact heat exchangers are as follows:

- Presence of acidic components in the heated water

- Possible presence of solids (e.g., soot, ash particles) in the hot water for certain fuels

- Limit on cooling water inlet temperature

- Possible increased maintenance due to plugging of packing or heat transfer material

- Possible longer payback period if fuel prices are low and a secondary heat exchanger is required (such as heating of boiler feed water)

\section{CHEs}

CHEs have a very high surface area to volume ratio. This compactness is achievable through higher surface densities (i.e., heat transfer surface area per unit volume of heat exchanger) and through enhancement of heat transfer coefficients by selection of heat transfer surface geometries. Such heat exchangers, ${ }^{19}$ when used for gas-to-gas heat exchange, have a surface density of $700 \mathrm{~m}^{2} / \mathrm{m}^{3}\left(213 \mathrm{ft}^{2} / \mathrm{ft}^{3}\right)$. When used for liquids or two-phase flows involving phase change (vaporizing or condensation), the surface density is about $300 \mathrm{~m}^{2} / \mathrm{m}^{3}\left(92 \mathrm{ft}^{2} / \mathrm{ft}^{3}\right)$. A typical shell and tube heat exchanger in comparison has a surface density of less than $100 \mathrm{~m}^{2} / \mathrm{m}^{3}\left(30 \mathrm{ft}^{2} / \mathrm{ft}^{3}\right)$ on the fluid side with plain tubes, and 2-3 times greater than that with high fin density. A higher surface area to volume ratio also results in smaller flow passages with two effects: (1) the tendency to develop a laminar flow in the channels and (2) high pressure drops. Laminar flow is associated with lower heat transfer coefficients, making it necessary to use various heat transfer enhancement techniques to improve efficiency. This has resulted in a wide variety of designs of CHEs, some of which have been in routine use for many decades (e.g., radiators). Continuous R\&D is underway as the demand increases for more innovative, efficient, and cost-effective designs.

The most commonly used CHE units are plate and frame heat exchangers and spiral heat exchangers. The plate and frame heat exchanger (Figure 3-9) consists of a frame in which closely spaced metal plates are clamped between a head and follower. The plates have corner ports with gaskets sealing the ports and along the plate edges. A double seal forms pockets open to atmosphere to prevent mixing of product and service liquids in the rare event of leakage past a gasket. Recent developments have introduced the double-wall plate. The plates are grouped into passes with each fluid being directed evenly between the paralleled passages in each pass. 


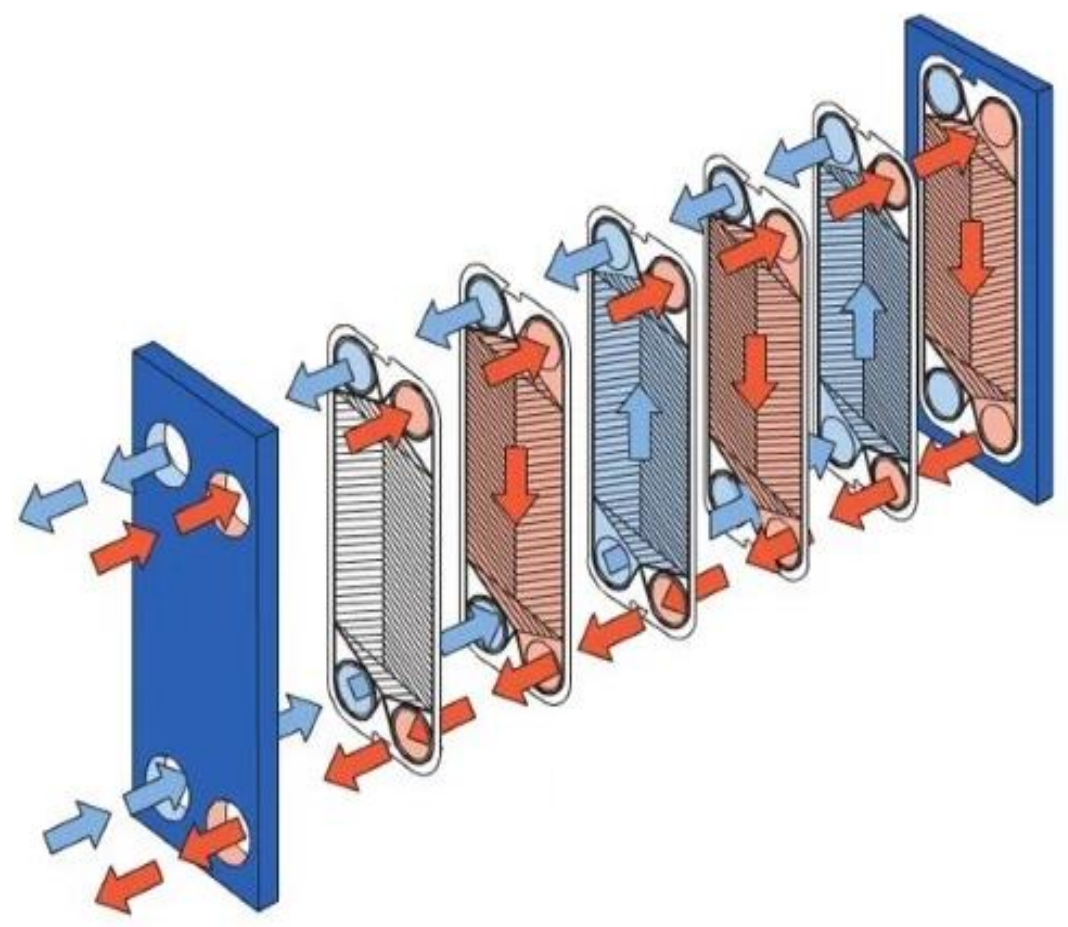

Figure 3-9. Typical plate and frame heat exchanger. Courtesy: Alfa Laval Heat Exchangers.

Plates are made from a range of materials, including stainless steel, titanium, Hastelloy, Avesta 254 SMO, Avesta 254 SLX, and any material ductile enough to be formed by a press. The special design of the trough pattern strengthens the plates, increases the effective heat transfer area, and produces turbulence in the liquid flow between plates. Plates are available between 25 gauge and 18 gauge $(0.5$ and $1.2 \mathrm{~mm})$ thickness with an effective heat transfer area ranging from 0.25 to $35 \mathrm{ft}^{2}\left(0.03\right.$ to $\left.3.5 \mathrm{~m}^{2}\right)$. Flow ports and associated pipework are proportional to the plate area and control the maximum liquid throughput. Until recently, applications for plate heat exchangers were restricted by the need for elastomeric gaskets, but recent advances in design have widened the range of applications by introducing brazed and welded plates.

Some of the advantages and features of the CHEs include the following:

- For liquid/liquid duties, the plate heat exchanger will usually give a higher overall heat transfer coefficient with similar pressure drop as a shell and tube heat exchanger.

- The effective mean temperature difference will usually be higher with the plate heat exchanger resulting in higher effectiveness.

- A plate heat exchanger is more compact than a tubular design, usually occupying less floor space.

- For most materials of construction, sheet metal for plates is less expensive per unit area than tubes of the same thickness.

- In many applications, the heat transfer surface of the plate is less susceptible to fouling than a tubular unit. This is due to higher fluid velocities, a high degree of turbulence (increasing the rate of foulant removal and resulting in a lower asymptotic fouling resistance), proper selection of plate material, and smooth surfaces. 
The most common WHR application for CHEs is heat recovery from hot liquids such as hot water discharged from processing equipment, engine cooling systems, and so on. CHEs are more suitable than direct contact heat exchangers to handle liquids with some contaminants (e.g., small particles, debris). With proper selection of plate and gasket material, they can handle corrosive liquids. CHEs are not typically used for low-density fluids such as gases, steam, or other vapors because of the restrictions in the flow area of the ports on plate units. From a mechanical viewpoint, the plate passage is not optimal for gas/vapor flow, and gasketed plate units are usually unable to withstand high operating pressures. The tubular heat exchanger will often be the most economical solution in this case since the plate heat exchangers are rarely made out of carbon steel. A plate heat exchanger can be economical if carbon steel construction is acceptable and when a closer temperature approach is not required.

More information on design and application of CHEs can be obtained from books and supplier literature that discuss various aspects of CHEs and their applications. ${ }^{20,21,22,23}$ The advantages and disadvantages of CHEs are summarized in Table 3-2.

Table 3-2. Advantages and disadvantages of plate and frame heat exchangers.

\begin{tabular}{|l|l|}
\hline \multicolumn{1}{|c|}{ Advantages } & \multicolumn{1}{|c|}{ Disadvantages } \\
\hline Low initial purchase cost (plate type) & $\begin{array}{l}\text { Narrow range of allowable pressures and } \\
\text { temperatures }\end{array}$ \\
\hline $\begin{array}{l}\text { Many different configurations available (gasketed, semi- } \\
\text { welded, welded, spiral) }\end{array}$ & $\begin{array}{l}\text { Subject to plugging/fouling because of the very } \\
\text { narrow flow path }\end{array}$ \\
\hline $\begin{array}{l}\text { High heat transfer coefficients (3 or more times greater than } \\
\text { for shell and tube heat exchangers because of the much } \\
\text { higher wall shear stress) }\end{array}$ & $\begin{array}{l}\text { Gasketed units require specialized opening and } \\
\text { closing procedures }\end{array}$ \\
\hline $\begin{array}{l}\text { Tend to exhibit low fouling characteristics because of the } \\
\text { high turbulence within the exchanger }\end{array}$ & $\begin{array}{l}\text { Material of construction selection is critical } \\
\text { because wall thickness is very thin (typically less } \\
\text { than 10 mm) }\end{array}$ \\
\hline $\begin{array}{l}\text { True countercurrent designs allow significant temperature } \\
\text { crosses to be achieved }\end{array}$ & \\
\hline $\begin{array}{l}\text { Require small footprint for installation and have small } \\
\text { volume hold-up }\end{array}$ & \\
\hline
\end{tabular}

\section{Spiral Heat Exchanger}

Spiral plate exchangers, shown in Figure 3-10, are a special class of CHEs that are mainly used to process viscous, heavily fouling fluids, or fluids containing particles or fibers. The heat exchanger is formed by winding two flat parallel plates together to form a coil with the ends welded or sealed with gaskets. In their normal orientation, spiral heat exchangers are true counter-current flow heat exchangers with hot and cold fluids flowing in opposite directions relative to each other. Normally, alternate edges of the passages are welded closed so that fluids can flow through continuous, isolated channels, thereby avoiding cross-contamination. The passage spacing (usually ranging from 0.25 to $1.25 \mathrm{in}$. depending on the fluid) is maintained primarily by sealing bars mounted at the passage edge and spacing studs. Certain designs do not contain spacing studs, such as units applied to handle sewage sludge, which reduces the likelihood of plugging. Depending on thermal and pressure drop requirements, passage width may range from 9 to 96 in. with complete units available from 5 to $3,000 \mathrm{ft}^{2}$. Covers with full face gaskets are fitted to each side of the unit. Material of fabrication may be carbon steel, SS304, SS316, L-grade stainless, alloy 20 , alloy 400 , alloy 200 , and many other weldable and cold workable material. General guidelines for pressure and temperature limitations are $150 \mathrm{psig}$ and $800^{\circ} \mathrm{F} .{ }^{114}$ 


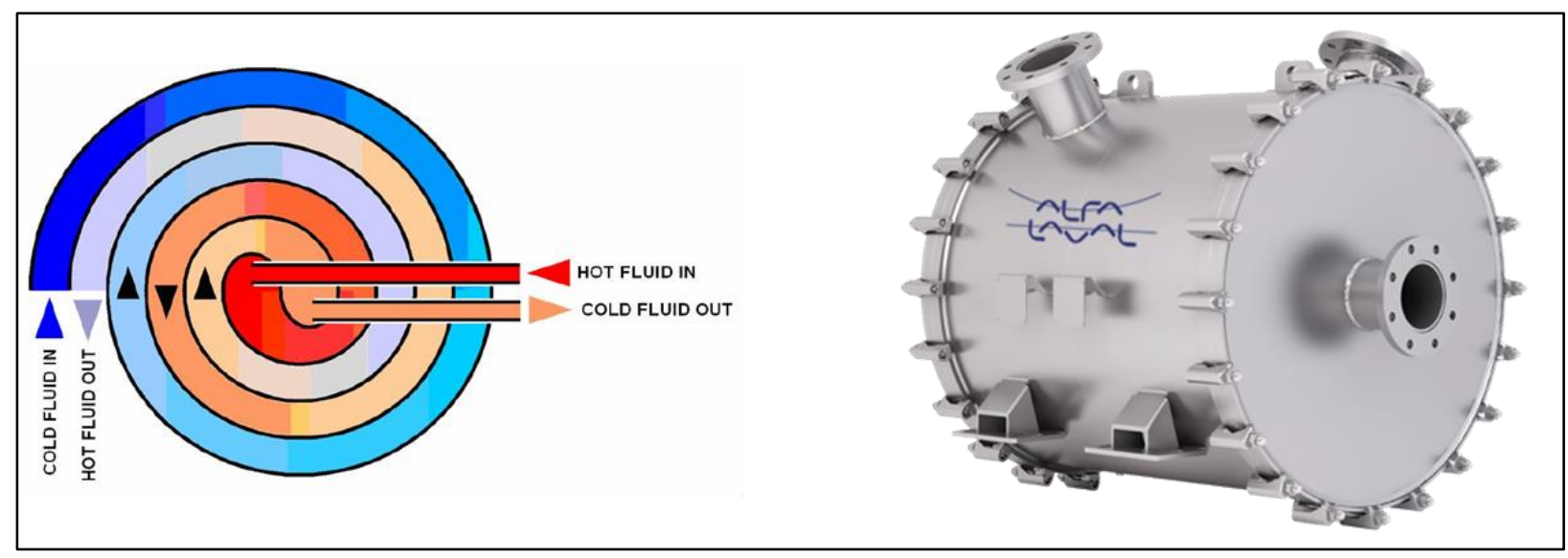

Figure 3-10. Spiral heat exchanger interior construction and the finished unit. Courtesy: Alfa Laval Heat Exchangers.

Spiral heat exchangers offer several advantages over other types of heat exchangers:

- Large passages that allow their use with sludge and other liquids with large solids content

- Each fluid flows through a single uniform passage, eliminating mal-distribution and localized low velocity areas

- Fully counter-current fluid flow for optimal thermal effectiveness

- Ease of inspection and cleaning of heat transfer surfaces by simply removing the covers

- Compact design requires less space than a conventional heat exchanger

- Spiral passage promotes turbulence and induces a scrubbing action, which lowers the fouling tendency

Spiral heat exchangers can be used for single-phase flow (liquid to liquid) or two-phase flow (vapor to liquid) heat transfer. Some of the single-phase applications for heat recovery applications include product heating or cooling, heat recovery economizers, and feed or bottom interchanges; two-phase applications include condensing and cooling of mixed vapors, steam heating of slurries, and other viscous materials in chemical industries.

\section{Recuperators}

The manufacturing industries use the term "recuperator" for a special class of gas to gas heat exchanger, which is used to preheat air using heat from exhaust gases. In a recuperator, heat exchange takes place between the flue gases and the air through metallic or ceramic walls. Metallic recuperators are used for low- to medium-temperature heat recovery applications whereas ceramic is used for high-temperature applications. A typical recuperator used on industrial heating equipment is shown in Figure 3-11. ${ }^{10}$ Flue gases from a furnace or oven pass through one side of the recuperator, separated by a wall from the cold combustion air.

There are many different configurations and designs of recuperators used by the industry. The different types are convective, radiation, hybrid, ceramic, and a special class known as self-recuperative burners. However, only one type - the convective recuperator - is of interest for low-temperature heat recovery. 


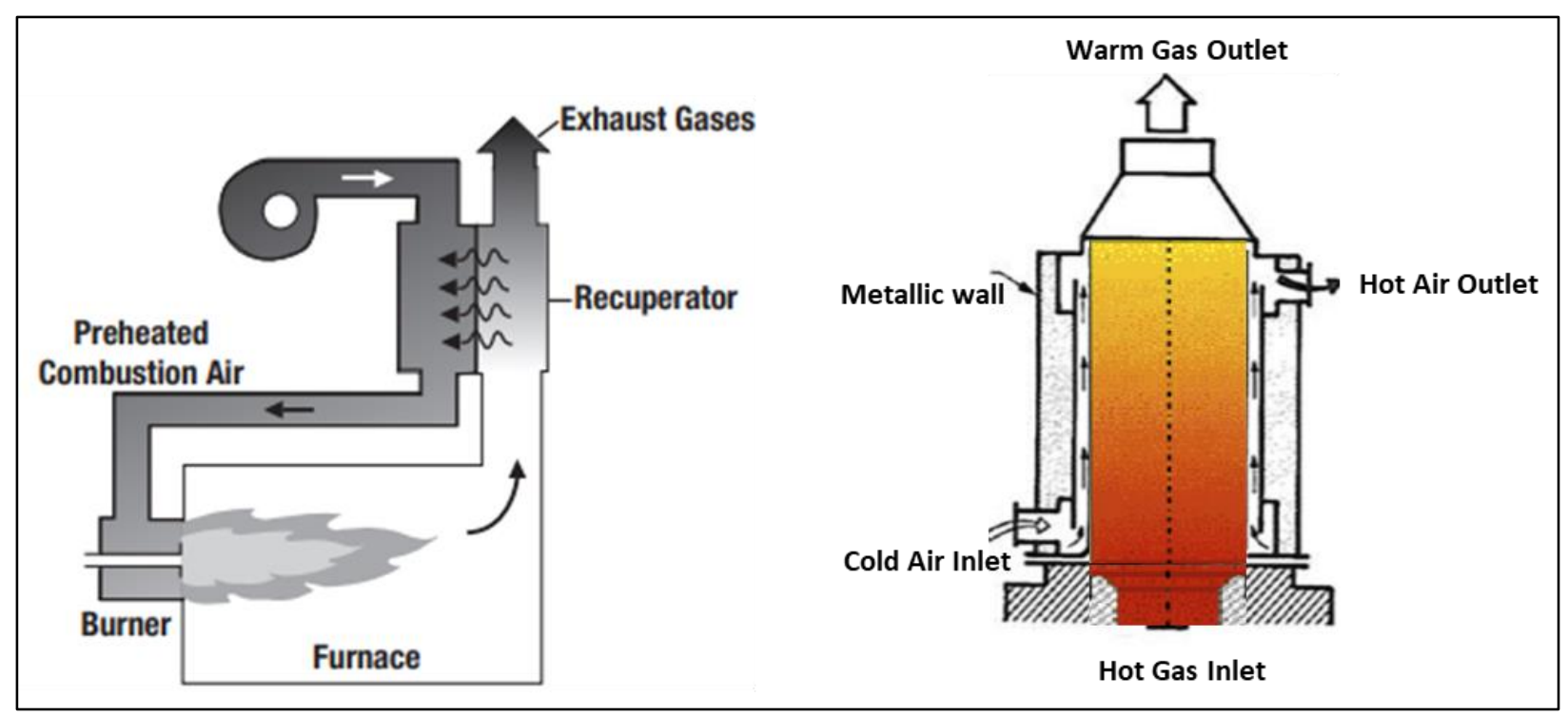

Figure 3-11. Typical recuperator design and application for combustion air preheating.

\section{Convective (convection) recuperator}

Convection recuperators use convection heat transfer from gases as the primary mode of heat transfer, comprising tube bundles or flat sheets to construct flow passages for the hot and cold gases. For lowtemperature applications, recuperators are constructed from metals such as aluminum and carbon steel. Convection recuperators are available in many sizes ranging from gas rates of less than $100 \mathrm{cfm}$ to as high as $10,000 \mathrm{cfm}$ and temperature ranging from $300^{\circ} \mathrm{F}$ to $1,600^{\circ} \mathrm{F}$. They use three primary flow configurations for the gases: parallel flow, counter-current flow, and cross flow, shown in Figure 3-12; variations of these are also common.

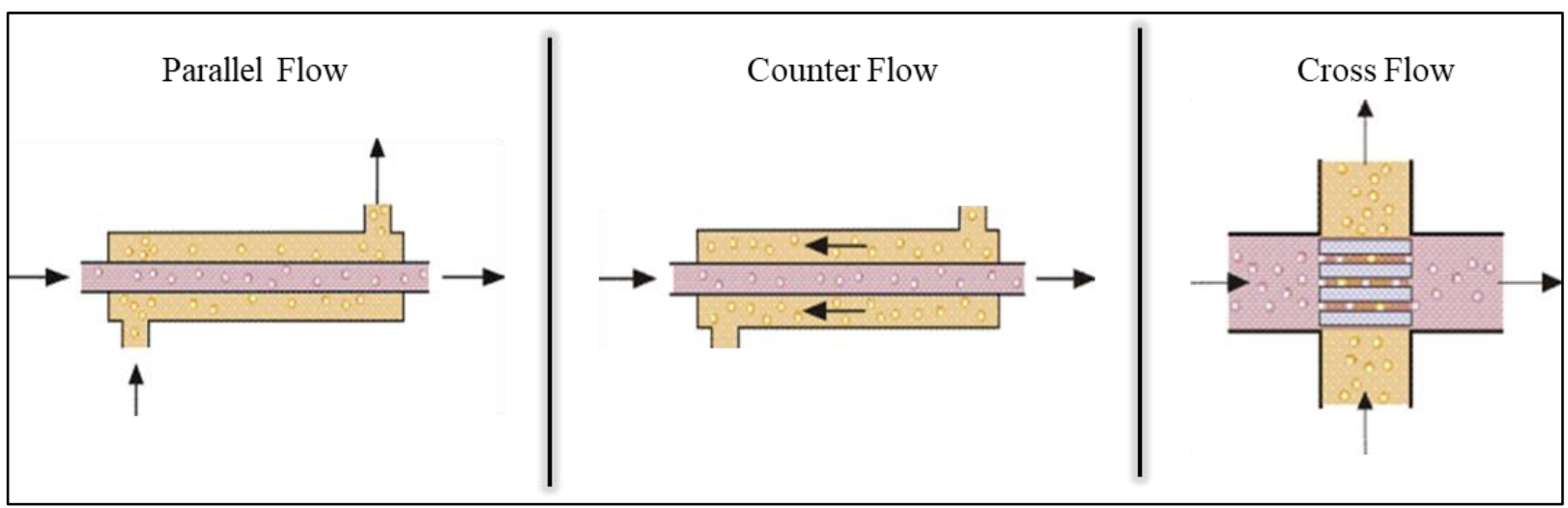

Figure 3-12. Three main configurations of convective recuperators.

Courtesy: Thermopedia.

In the counter flow arrangement, hot gases flow in the opposite direction of the air flow, resulting in highest temperature difference throughout the heat exchanger. In parallel flow systems, the hot gas and cold air enter at the same level or plane and flow parallel to each other as heat from gases is transferred to the air. Peak metal temperature is lower for parallel-flow systems than it is for counter-flow recuperators. In cross-flow recuperators, the gas and air flows are in perpendicular directions, resulting in the peak metal temperature being located at the bottom part of the recuperator tubes. In general, achievable air temperature for a given set of values for the air and gas flows is the highest for counter-flow recuperators 
and the lowest for parallel-flow recuperators. Selection of recuperator configuration largely depends on the application and allowable peak metal temperature. Specifically, selection of a recuperator is based on the following parameters:

- Exhaust or hot gas: flow, temperature, moisture content, presence of corrosive materials (type and concentration), and particulates (type and concentration)

- Air or cold gas: flow, temperature, moisture content, presence of corrosive materials (type and concentration), and particulates (type and concentration)

- Required air preheat temperature

- Allowable pressure drops on the hot gas and cold air sides

- Operating schedule and possible changes in these values of the mentioned parameters with time

- $\quad$ Type of fuel, fuel cost, and operating hours

Design and installation of a recuperator requires consideration and allowance for many issues, such as thermal expansion, insulation of exposed surfaces, allowance for accessibility, inspection of internal parts, monitoring of inlet gas temperature to avoid accidental high temperature of hot gases entering the recuperator, and provision for controlling inlet hot gas temperature through injection of cold air in hot gases. It is also desirable to monitor hot gas composition to detect presence of combustible gases when the hot gases are products of combustion from fired heating equipment. In many large installations, it is common to monitor outlet temperature of heated air and pressure drop on the hot and cold gas sides to detect any abnormality and possible leakage due to tube or seal failure.

Performance of a recuperator is expressed in terms of effectiveness, given by the following equation.

$$
E f f=\frac{\Delta \mathrm{H}_{\mathrm{air}}}{\Delta \mathrm{H}_{\max }}
$$

where

$$
\begin{aligned}
& \text { Eff }=\text { effectiveness of the recuperator } \\
& \Delta \mathrm{H}_{\text {air }}=\text { heat transferred to air (Btu/h) } \\
& \Delta \mathrm{H}_{\max }=\text { heat available from hot gas }(\mathrm{Btu} / \mathrm{h})
\end{aligned}
$$

It is often necessary to know the amount of heat transferred and, more specifically, the temperature of heated air leaving the recuperator. This can be calculated via the heat available from hot gases and supplier-provided recuperator effectiveness.

\section{Performance of recuperators}

As discussed in a previous section, recuperator performance can be stated as its effectiveness and preheated combustion air temperature delivered. However, for a given recuperator, both parameters can change significantly as the temperature and flow of the inlet gases change. In practical applications, both parameters change as the operating conditions change for the equipment on which a recuperator is installed. 
The recuperator equipment suppliers offer recuperators in standard and custom designs. They use detailed heat transfer calculations to determine effectiveness for a certain operating condition, including hot gas flow, temperature, cold air flow, and dimensions of the recuperator heat transfer surfaces. However, the final results stated in the performance guarantee are based on testing of one or more units under a set of operating conditions and then extrapolating and/or interpolating for the performance, as well as simulation modeling. The change in flow and temperature of air and gas within the recuperator affects heat transfer, effectiveness, and the combustion air temperature delivered at the exit end of a recuperator. Therefore, the given effectiveness is not valid for heat transfer calculations at all operating conditions.

Typical performance for a convection recuperator shows that the combustion air temperature increases as the flows go down. Further calculations using exit air temperature also indicate that the recuperator effectiveness increases as the flows go down. As a result of this, the peak metal temperature for the recuperator could go up. Hence, the material selection for a recuperator should be based on the "turndown" operating conditions and not the high-flow design conditions.

Detailed information on design, performance, and application of recuperators is available in References 14 and 15. A list of suppliers is given in Reference 16.

\section{Regenerators}

Regenerators are used as an alternative option to recover waste heat from hot gases to heat air. Static bed and rotary regenerators are the two basic designs of regenerators. Static bed regenerators are rarely used for low-temperature heat recovery. Their use is limited to high-temperature heating systems such as glass melting, steel reheating furnaces, aluminum melting furnaces, and blast furnace air heating. Rotary regenerators, commonly known as heat wheels, are used for heat recovery in low- to medium-temperature applications.

A heat wheel consists of a properly sized porous disk rotating between two side-by-side cold and hot

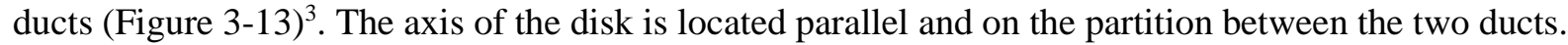
The core of the wheel, known as the "wheel matrix," permits heat and moisture transfer between the two airstreams. One of the most common matrix materials is aluminum because of its high thermal conductivity and high specific heat compared with carbon steel. However, depending on operating temperature, several other matrix materials such as ceramics, stainless steel, plastics, and paper are also used.

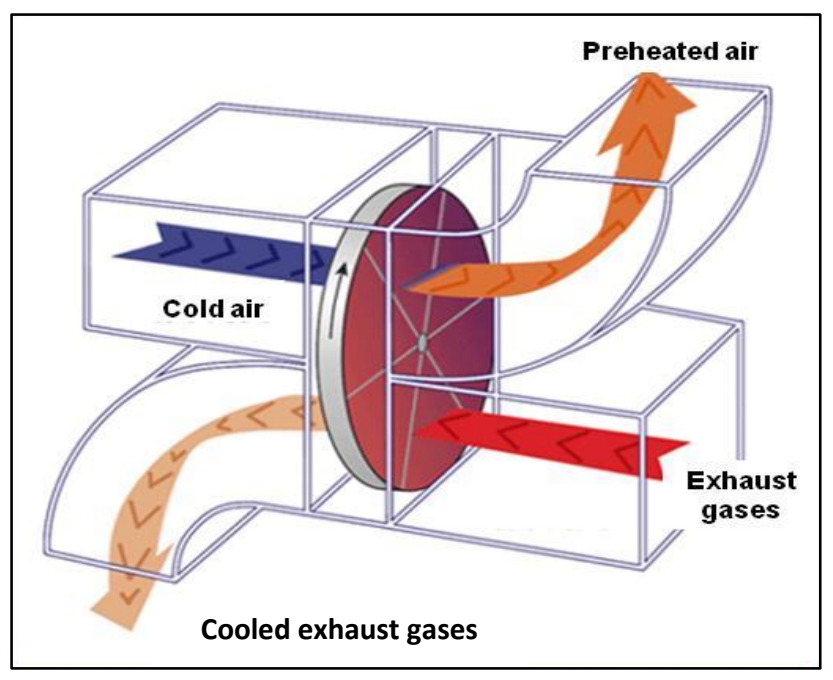

Figure 3-13. Typical heat wheel WHR unit. 
In the low-temperature heat wheel design, the matrix material is corrugated metal to form small flow channels (e.g., sinusoidal, triangular, or hexagonal) with a height of about $2 \mathrm{~mm}$. These small flow channels result in a large surface area for heat and mass transfer. The effectiveness of heat exchangers strongly depends on the heat transfer surface area - the larger the surface area, the greater the effectiveness. Therefore, heat wheels have very high heat transfer surface area to volume ratios. Commercial heat wheels often have heat transfer surface area to volume ratios of about $800-4,000 \mathrm{~m}^{2} / \mathrm{m}^{3}$ ( 250 to $1,250 \mathrm{ft}^{2} / \mathrm{ft}^{3}$ ), which results in very high heat transfer even with compact wheels.

In the most used heat wheel design, hot air transfers sensible heat to the disk, making the metal hot. As the disk rotates from the hot side to the cold side, cold air picks up heat from the hot metal matrix, cooling the metal. Further rotation of the disk brings it back to the hot air duct side to heat the matrix again and the cycle continues. The overall efficiency of sensible heat transfer for this kind of regenerator can be as high as $85 \%$. Its main area of application is where heat is exchanged between large masses of air having small temperature differences. The typical application of heat wheel fabricated from materials such as aluminum or carbon steel is for low- to medium-temperature gases, usually limited to about $600^{\circ} \mathrm{F}$.

The heat wheel system requires good seals between the higher-pressure air being heated and the lowerpressure exhaust gases. Reliability of seals and plugging up of the gas passages have been the major drawbacks of a heat wheel. Several steps have been taken to improve and automatically adjust the seals to control air leaks as the seals wear out with the use.

Heat wheels are commonly used for preheating combustion air for large boilers. The commonly known Lungstrom air preheater is an example of a metallic heat wheel used to preheat combustion air. This type of heat exchanger design includes special arrangement for adjusting the seals and cleaning the heat transfer surfaces. Application of heat wheels is very limited for industrial furnaces; however, they are commonly used for low-temperature ovens and dryers. They can recover heat from oven exhaust gases to preheat building ventilation air or makeup air for the ovens and dryers. Another application of the heat wheel is in industrial plant buildings, where it is used to recover heat from ventilation air especially during cold climate conditions. Desiccant heat wheels are a special type of heat wheel that is primarily used to remove moisture from process air or building air. These are not technically heat recovery systems, but they play an important role in improving process thermal efficiency for certain applications.

\subsection{HEAT PIPE}

Heat pipes are a heat recovery device with no moving parts. As shown in Figure $3-14,{ }^{3}$ the heat pipe comprises three elements - a sealed container, a capillary wick structure, and a working fluid. The capillary wick structure is integrally fabricated into the interior surface of the container tube and sealed under vacuum. In many cases, the tube outer surface has extended surfaces or fins to enhance heat transfer between the fluid (gases) and the heat pipe unit. Heat applied to the external surface of the heat pipe is in equilibrium with its own vapor as the container tube is under vacuum. Thermal energy applied to the external surface of the heat pipe causes the working fluid near the surface to evaporate instantaneously (latent heat of vaporization). This part of the heat pipe is usually referred to as the "evaporator region." The vapor then travels to the other end of the pipe or the condenser region, where the thermal energy is removed, causing the vapor to condense into liquid again (latent heat of condensation). The condensed liquid then flows back to the evaporated region. Commonly used fluids are ammonia, acetone, the Freon compounds, and water. Water, which is perhaps the most widely used working fluid, has good thermophysical properties such as large heat of vaporization and surface tension, and has the added benefit of being safe to use during handling. 


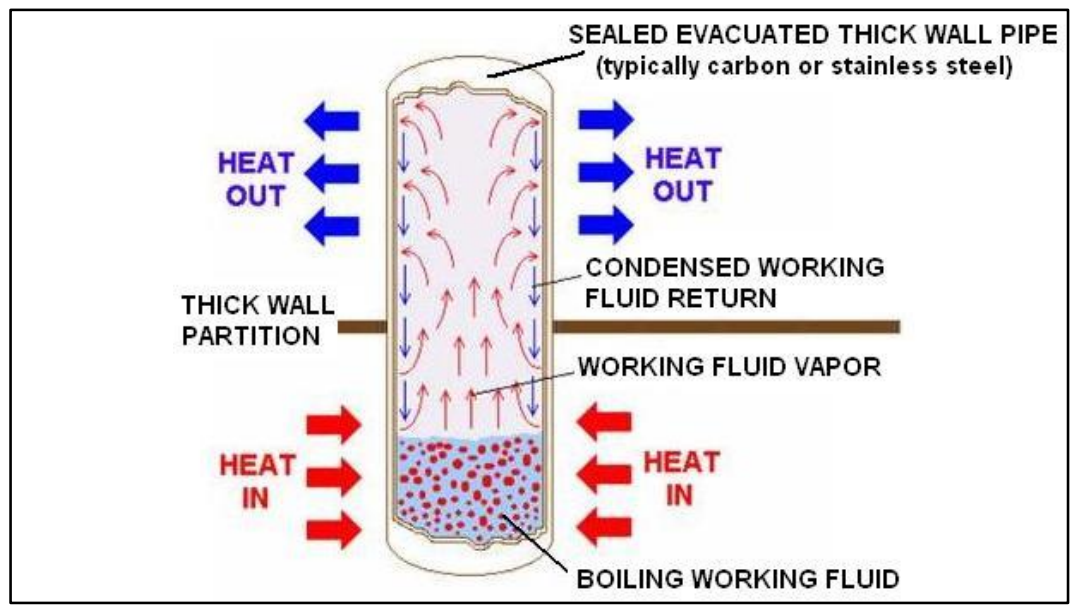

Figure 3-14. A heat pipe construction and functional schematic.

Heat pipes can be used to transfer heat between gases to gases, gases to liquids, or liquids to liquids, and to raise low-pressure steam using heat from medium-temperature waste heat. The design, dimensions, orientation and other factors depend on the specific application. Heat pipes have been used in many types of applications in a variety of industries.

A commercially available unit consists of a bundle of tubes of varying diameter (from as small as 1/8 to 1 in. and larger) and lengths to meet specific application requirements. A typical assembled unit (gas-toliquid unit designed by Spirax Sarco) is shown in Figure 3-15.

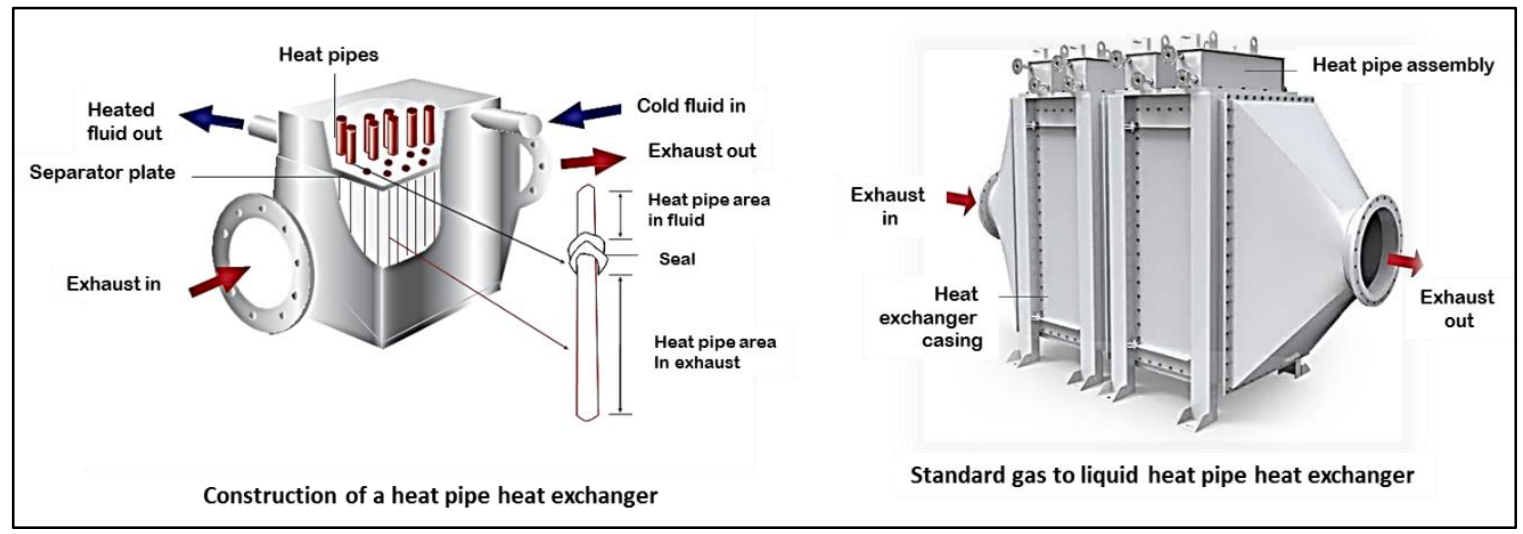

Figure 3-15. Assembled unit of heat pipes for use in gas to liquid heat transfer. Courtesy: Spirax Sarco.

The heat pipe heat exchanger needs very little mechanical maintenance because no parts wear out. It does not need input power for its operation, and it is free from cooling water and lubrication systems. It also lowers the fan horsepower requirement and increases the overall thermal efficiency of the system. The heat pipe heat recovery systems can operate up to $600^{\circ} \mathrm{F}$ with $60 \%$ to $80 \%$ heat recovery capability.

The temperature limit of a heat pipe is determined by the material of construction (outer tube), type of working fluid, wick material, and contaminant composition of gases and liquids. In most cases, copper, aluminum, or carbon steel is used for the tube and extended surfaces. Stainless steel is used in the presence of acidic gases and at high temperatures. Heat pipe designs are available for temperatures as high as $1,600^{\circ} \mathrm{F}$. 


\section{Typical heat pipe applications}

Heat pipes are used in the following industrial applications:

- Space heating: Heat pipe transfers the thermal energy from process exhaust for building space heating. The preheated air can be blended, if required. The requirement of additional heating equipment to deliver heated makeup air is drastically reduced or eliminated.

- Process to process: Heat pipe heat exchangers recover thermal energy waste from the process exhaust and transfer this energy to the incoming process air. The incoming air becomes warmer and can be used for the same process or for other processes, reducing process energy consumption.

- HVAC applications:

○ Cooling: Heat pipe heat exchangers precool the building makeup air in the summer and reduce the total tons of refrigeration to be delivered by the cooling system. Thermal energy is transferred to the cool exhaust from the hot supply makeup air, which results in cooler supply makeup air.

- Heating: The above process is reversed during the winter to preheat the makeup air.

- Other applications:

- Preheating boiler combustion air

- Recovering waste heat from furnaces

- Reheating fresh air for hot air driers

- Recovering waste heat from catalytic deodorizing equipment

- Reusing furnace waste heat as heat source for other ovens

- Cooling closed rooms with outside air

- Preheating boiler feed water with WHR from flue gases in the heat pipe economizers

- Drying, curing, and baking ovens

- Reclaiming waste steams

- Recovering waste heat from Brick kilns (secondary recovery)

$\circ$ Recovering waste heat from Reverberatory furnaces (secondary recovery)

\subsection{HEAT PUMPS}

In the various options previously discussed, waste heat spontaneously transfers "downhill" from a hot fluid to a lower temperature fluid. When energy is repeatedly transferred or transformed, it eventually has such low intensity (resides in a medium at such low temperature) that it can no longer be viable to use for most applications.

It has been a general rule of thumb in industrial operations that fluids with temperatures lower than $250^{\circ} \mathrm{F}$ are the limit for WHR because of the risk of condensation of corrosive liquids. However, when fuel costs rise, even such waste heat can be used economically for space heating and other low-temperature applications. It is possible to reverse the direction of spontaneous energy flow by using a thermodynamic system: heat pumps.

Most heat pumps work on the principle of the vapor compression cycle. In this cycle, the circulating substance is physically separated from the source (waste heat, with a temperature of $T_{\text {in }}$ ) and user (heat to be used in the process, $T_{\text {out }}$ ) streams, and is reused in a cyclical fashion, therefore being called a "closed cycle." As shown in Figure 3-16, the following processes take place in a heat pump:

- In the evaporator, the heat is extracted from the heat source to boil the circulating working fluid. 
- The low-temperature working fluid vapor is compressed by a compressor, which requires external work. The work done on the vapor raises its pressure and temperature to a level at which its energy becomes available for use.

- The heat is delivered to the condenser, where it is transferred to the process.

- The throttling valve reduces the pressure of the circulating working fluid back to the evaporator condition, where the cycle repeats.

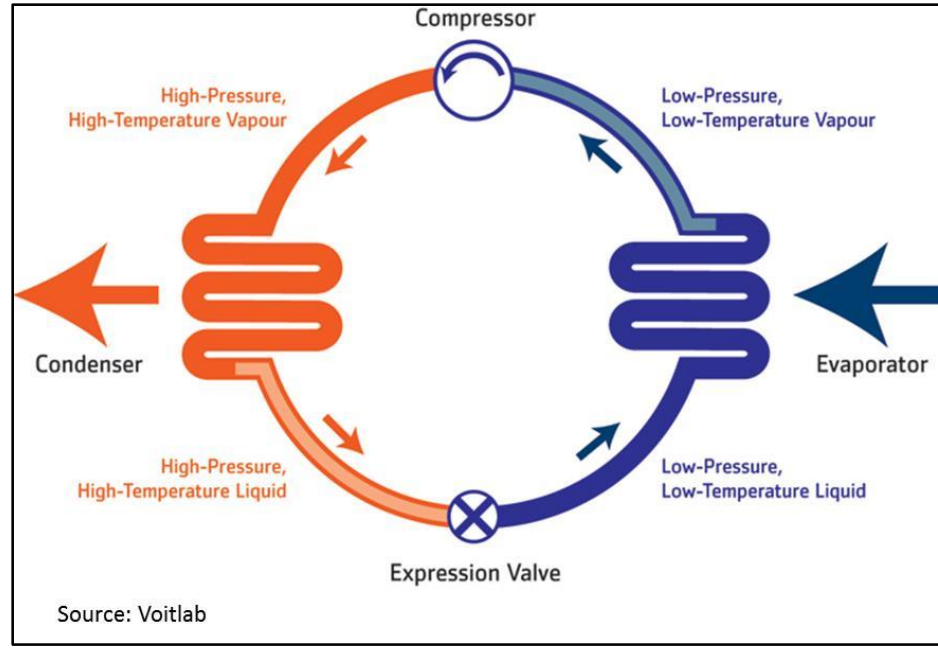

Figure 3-16. Working principle of a heat pump for heat recovery applications.

Heat pump applications are most promising when the heating and cooling capabilities can be used in combination (e.g., a plastics factory where chilled water is used to cool injection-molding machines while the heat output from the heat pump is used to provide factory or office heating). Other examples of heat pump installation include product drying, maintaining dry atmosphere for storage and drying compressed air. Application of heat pumps for industrial applications is not given much consideration; however, heat pumps can be used for several applications in an industrial plant, shown in Figure 3-17. ${ }^{24}$

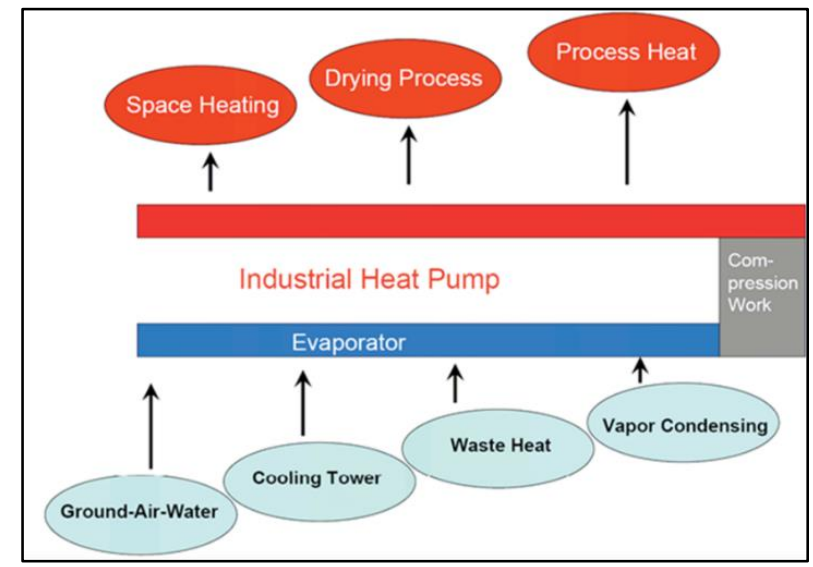

Figure 3-17. Industrial application areas for heat pumps.

The performance of heat pump is rated in coefficient of performance (COP), which is the ratio of heat output to the amount of energy input. 
$\mathrm{COP}=\mathrm{h}_{\mathrm{h}} / \mathrm{h}_{\mathrm{w}}$

where

$$
\begin{aligned}
& h_{h}=\text { heat produced }(B t u / h) \\
& h_{w}=\text { equivalent electric energy input }(B t u / h)=3,412 \text { electrical input energy }(W)
\end{aligned}
$$

For a given working fluid, the effective COP will depend on the heat pump inlet pressure and the discharge pressure required to deliver the needed process temperature. In industrial applications, a heat pump COP is in the range of 2.0 to $6.0 .^{25}$

Most common applications of heat pumps are listed as follows.

- Space heating: Heat pumps can use conventional heat sources for heating and cooling in industrial buildings by recovering low-grade (at $<100^{\circ} \mathrm{F}$ ) industrial waste heat that could not be used directly, and provide a low- to medium-temperature heat that can be used internally or externally for space and greenhouse heating.

- Process water heating and cooling: Many industries need warm process water in the temperature range of $100^{\circ} \mathrm{F}$ to $200^{\circ} \mathrm{F}$ and often have a significant hot water demand in the same temperature range for washing, sanitation, and cleaning purposes. This need can be met by heat pumps. Heat pumps can also be a part of an integrated system that provides both cooling and heating.

- Steam production: Industry consumes vast amounts of low-pressure steam in the temperature range of $250^{\circ} \mathrm{F}$ to $350^{\circ} \mathrm{F}$ in industrial processes and for heat distribution. Current high-temperature heat pumps can produce steam up to $300^{\circ} \mathrm{F}$.

- Drying processes: Heat pumps are used extensively in industrial dehumidification and drying processes at low and moderate temperatures (maximum of $200^{\circ} \mathrm{F}$ ). The main applications are drying of pulp and paper, various food products, forest products, powders, pharmaceutical materials, and so on.

- Evaporation and distillation processes: Evaporation and distillation are energy-intensive processes, and most heat pumps are installed in these processes in the chemical and food industries. In evaporation processes, the residue is the main product, whereas the vapor (distillate) is the main product in distillation processes.

\subsection{THERMOCOMPRESSOR}

In many cases, very low-pressure steam is condensed and reused as water for lack of a better option of reuse. In some cases, mixing this low-pressure steam with very high-pressure steam and producing medium-pressure steam for reuse is feasible. Much of the energy in low-pressure steam is in its latent heat value and thus, thermo-compressing would offer a large improvement in WHR.

The thermo-compressor is a simple equipment: a nozzle where high-pressure steam (motive steam) is accelerated into a high-velocity fluid. This entrains the low-pressure vapor or steam (suction steam) by momentum transfer and then recompresses in a divergent venturi (Figure 3-18). 


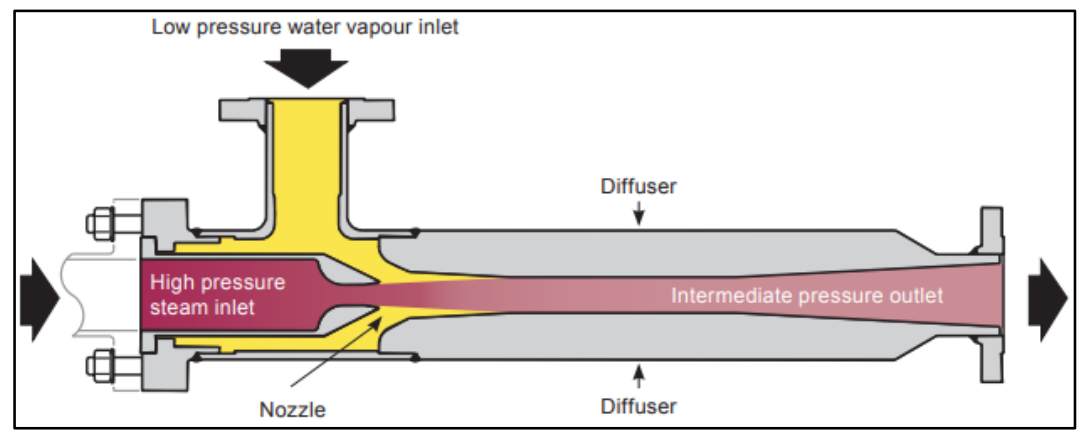

Figure 3-18. Thermocompressor components. Courtesy: Spirax Sarco.

Applications such as evaporators and paper dryers use thermocompressors to recompress the boiling steam and use it as heating steam. Thermocompressor selection is based on the required compression ratio, defined as the ratio of discharge pressure to suction pressure with all pressures measured in absolute pressure. For most applications, the thermocompressor system is designed to keep compression ratio lower than 1.8 to 2.1 to avoid use of sonic or critical velocity of the motive steam beyond which flow can be choked.

When applied properly, thermocompressors offer several advantages:

- Simple construction — steam jet thermocompressors can be made from any machinable materials for increased abrasion resistance.

- Compact design and comparatively lightweight enables overhead installations.

- No moving or rotating parts lead to minimal maintenance requirements; therefore, the units can be installed in remote or inaccessible locations.

- Discharge steam is oil-free, and there is no lubrication contamination.

- Thermocompressors are suitable for hazardous areas; no explosion-proof motors are required.

- Recirculation occurs without loss of heat or energy through reducing valves.

Figure 3-19 illustrates the application of a thermocompressor on a paper-drying machine using steam as the source of heat. In this case, the thermocompressor pressurizes the lower-pressure flash steam from a condensate collection vessel to the required steam pressure using higher-pressure steam or motive steam. This system allows recovery and recirculation of flash steam while recovering part of the energy content of the return condensate. 


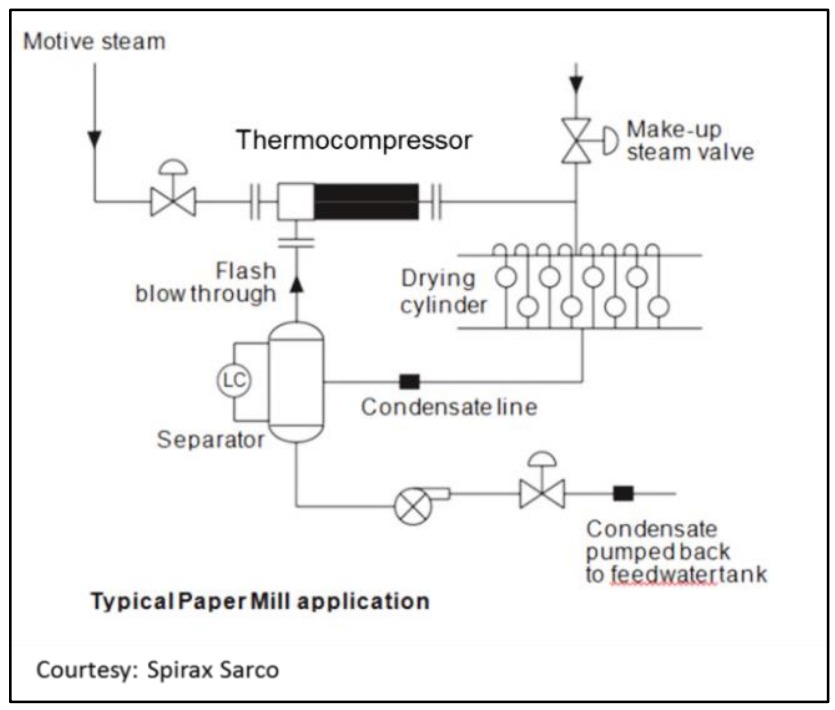

Figure 3-19. Application of a thermocompressor on a paper-drying machine.

The operating requirements (such as the final pressure and amount of steam required for the process) are used to determine pressure and quantity of motive (high-pressure) steam required for thermocompressor operation. Blatchley and Stratton ${ }^{26}$ give guidance on this by using certain standard-size thermocompressors.

\subsection{THERMALLY ACTIVATED TECHNOLOGIES}

Thermally activated technologies consists of equipment using thermal energy for heating, cooling, humidity control, and power (mechanical and electric). They include absorption chillers for cooling, desiccant systems for humidity control, and organic Rankine systems for power generation. CHP systems that use waste heat for power generation are also considered a thermally activated technology.

\section{Absorption Chillers}

Absorption chillers transfer recovered waste heat to an absorbent fluid and a refrigerant. There are two primary systems, which use two different working fluid mixtures: ammonia-water and LiBr-water. Ammonia-water systems are used by cooling equipment, ranging from small refrigerators to large heatrecovery machines installed with power plants. Ammonia is an excellent refrigerant with a high latent heat and excellent heat transfer characteristics. However, because of its toxicity, it is used only in limited applications and is usually set up outdoors to allow natural dilution of any leaks. Aqueous $\mathrm{LiBr}$ is used for all types of systems and is being widely used to avoid concerns about toxicity of ammonia-based systems.

A $\mathrm{LiBr}$ system uses solution of water and $\mathrm{LiBr}$ as a working fluid instead of an ammonia and water mixture. The system uses waste heat in the form of low-pressure steam or hot water to supply necessary energy to power the system. The thermal system replaces a compressor used in electrically driven vapor compression systems commonly used by the industry.

As shown in Figure 3-20, ${ }^{3}$ a typical LiBr absorption chiller includes two vessels or shells. The upper shell contains the generator and condenser; the lower shell contains the absorber and evaporator. Heat supplied in the generator section is added to a solution of $\mathrm{LiBr}$-water. This heat causes the refrigerant, in this case water, to boil out of the solution in a distillation process. The water vapor then passes into the condenser section, where a cooling medium condenses the vapor back to a liquid state. The water then flows down to the evaporator section, where it passes over tubes containing the fluid to be cooled (labeled "chilled 
water" in the figure). By maintaining a very low pressure in the absorber-evaporator shell, the water (i.e., "liquid refrigerant") boils at a very low temperature. This boiling causes the water to absorb heat from the fluid to be cooled, thus lowering its temperature. The evaporated water (formerly the liquid refrigerant) then passes into the absorber section, mixing with the concentrated $\mathrm{LiBr}$-water solution. This strong solution (strong in LiBr) absorbs the vapor from the evaporator section to form a weaker solution. This is the absorption process that gives the cycle its name. The weak solution is then pumped to the generator section to repeat the cycle. One of the biggest advantages of the $\mathrm{LiBr}-$ water system is its ability to produce chilled liquid temperatures below $32^{\circ} \mathrm{F}$.

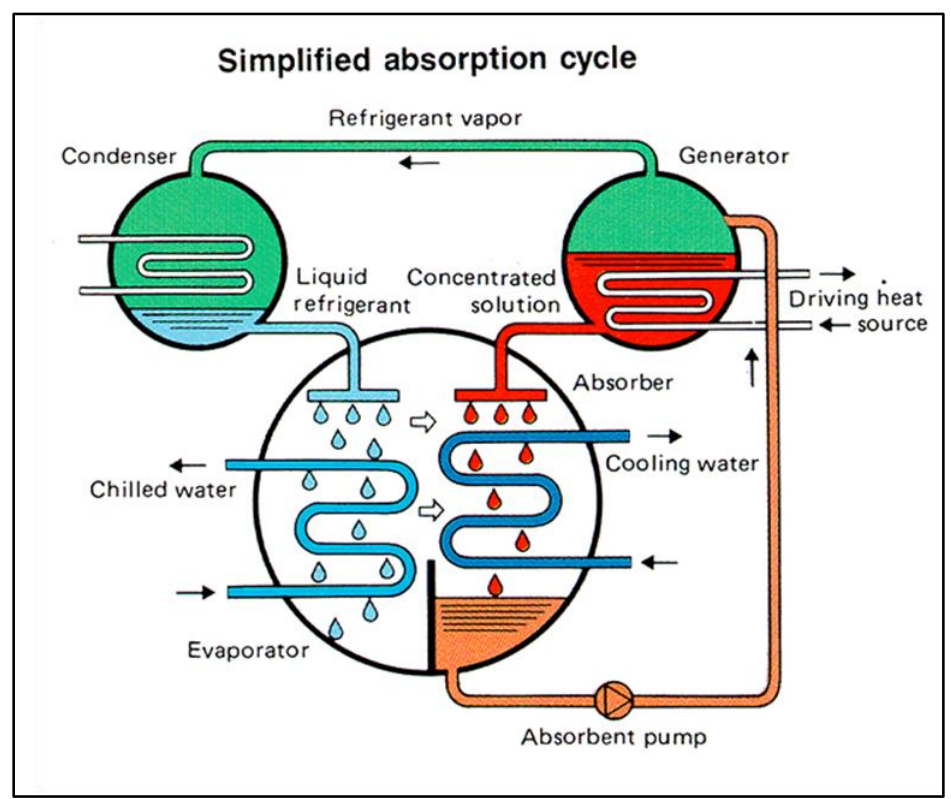

Figure 3-20. Simplified absorption cycle using waste heat.

The system discussed is a single-effect absorber system. Two variations use advanced heat transfer components, known as "double effect" and "triple effect" systems. The double effect unit requires two condenser and generator systems, and the triple effect unit requires three condensers and generators. These systems offer better performance in terms of energy use compared to single-effect system but comes with an added cost.

Efficiency of cooling systems or chillers is indicated by COP, which is defined as cooling output divided by the required heat input. For a single-effect unit that does not include extensive heat recovery heat exchangers, the COP is in the range of 0.5 to 0.7 . For double- and triple-effect systems, the range of COP is 1.0 to 1.1 and 1.4 to 1.5 respectively. A comparable electrically operated system would have a COP of 4.5 to 6.0 , but since absorption units use waste heat, the operating cost is very small compared with the electrical units.

Choice of a particular system (single, double or triple) is driven by generator heat source temperature. The following list obtained from Papar $^{27}$ matches the type of system to heat sources commonly used for industrial systems.

- $\quad$ Single-effect

- Generator temperature $\left(180^{\circ} \mathrm{F}-300^{\circ} \mathrm{F}\right)$

- Waste heat fired

- Hot water fired $\left(180^{\circ} \mathrm{F}-220^{\circ} \mathrm{F}\right)$

- Steam fired $(<15 \mathrm{psig})$ 
- Double-effect

- Generator temperature $\left(275^{\circ} \mathrm{F}-350^{\circ} \mathrm{F}\right)$

- Steam fired (>50 psig)

- Direct natural gas fired

- Triple-effect

- Generator temperature $\left(350^{\circ} \mathrm{F}-400^{\circ} \mathrm{F}\right)$

- Steam fired (>100 psig)

- Direct natural gas fired

There are several important operating issues associated with $\mathrm{LiBr}$ systems. The minimum temperature must remain above $40^{\circ} \mathrm{F}$. It is necessary to control the unit operation to maintain the solution concentration above crystallization point to avoid salt crystallization. This requires the use of several built-in safety systems. Additionally, the units have relatively large footprint because of the use of large vessels.

\section{Ammonia Water Absorption System}

In a single-effect ammonia-water system as shown in Figure $3-21,{ }^{27}$ ammonia is the refrigerant and water is the absorbent. High-pressure liquid refrigerant from the condenser passes into the evaporator through an expansion valve that reduces the pressure of the refrigerant to the low pressure existing in the evaporator. The liquid refrigerant vaporizes in the evaporator by absorbing heat from the medium being cooled, and the resulting low-pressure vapor passes to the absorber. The low-pressure vapor from the evaporator is absorbed by the strong solution coming from the generator through an expansion valve, and forms the weak solution in absorber. The weak solution is pumped to the generator, where the refrigerant in the solution boils off. Heat for boiling off the refrigerant is supplied from hot water or steam produced from waste heat or another source, such as flash steam. The remaining solution flows back to the absorber and thus completes the cycle. For the ammonia-water system, an analyzer and a rectifier is used to remove water vapor from the refrigerant mixture leaving the generator before reaching the condenser.

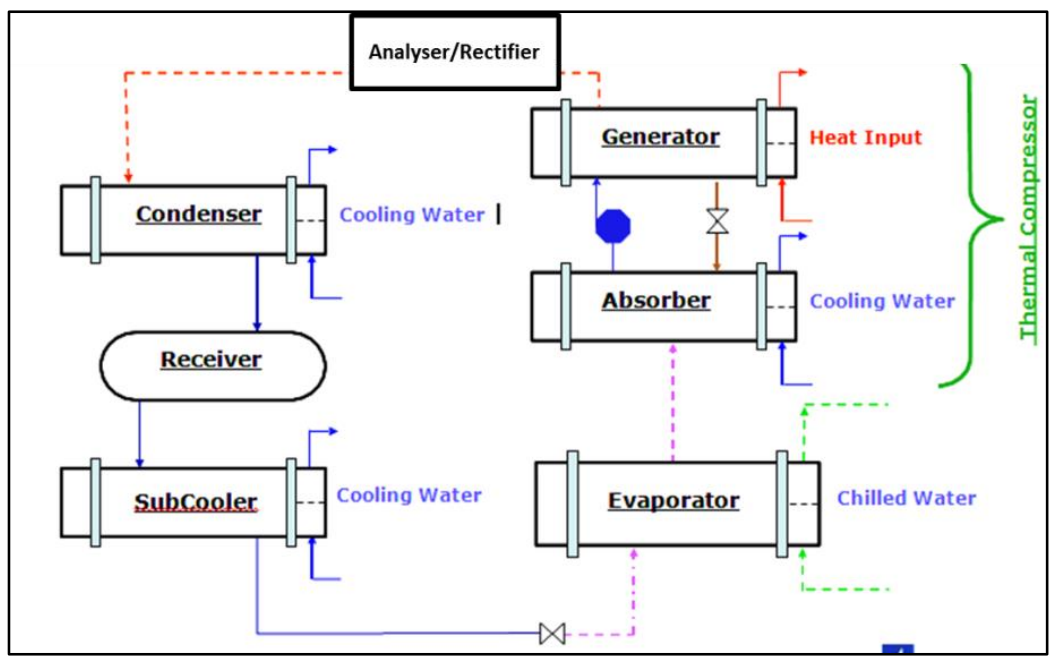

Figure 3-21. Schematic of a single-effect ammonia-water absorption chiller system.

Ammonia-water systems can use a variety of heat sources, such as waste or process surplus steams, hot water, and geothermal or solar heat, at as low as $150^{\circ} \mathrm{F}$. The COP value peaks out at about 1.5 for advanced systems (such as triple-effect systems) with additional heat exchangers and other components. Payback for these systems depends on the cost of the heat source, capital cost, and cost of electricity, 
which would have to be used to produce the required cooling. If the source of heat is waste heat, it is possible to justify such systems with less than a 3-year payback period.

The cost for these systems (operating and capital or investment) varies from $\$ 750$ to $\$ 1,000$ per refrigeration ton. This includes the cost of the unit as installed at the location plus cost for auxiliary condenser equipment (cooling tower, cooling water pumps, and cooling water piping). In most cases, the cost of the absorption system could be $50 \%$ higher than the equivalent electrical system. The auxiliary system cost is approximately $33 \%$ of the total cost of the system. 


\section{NEW AND EMERGING TECHNOLOGIES}

In response to the availability of large amounts of low-temperature waste heat in manufacturing plants, new technologies to use this low-grade waste heat are being developed or demonstrated. Most of these technologies focus on the conversion of thermal energy (heat) into electrical energy using lowtemperature heat sources, such as flue gases or liquid streams (heat recovery system fluids). Over the past three decades, several commercial products based on advanced systems (i.e., the ORC, ammonia-waterbased, and supercritical $\mathrm{CO}_{2}\left[\mathrm{sCO}_{2}\right]$ systems) have been developed and tested at manufacturing plants as a result of research activities by national laboratories and private companies. Other efforts have been directed to thermal storage, thermally activated technologies (cooling systems using waste heat), mechanical methods of energy conversion, and thermoelectrical systems. Many of these technologies are not yet widely adopted by the US industries. Adoption of these new technologies is hampered by relatively low conversion efficiency, low natural gas prices, and the desire for shorter payback periods (in some cases, less than 2 years). However, some companies have selected to install and test these new technologies as demonstration projects or to be pioneers in new and emerging technologies. The following sections describe some of these technologies and provide case studies highlighting the performance of the selected technologies.

\subsection{ORGANIC RANKINE CYCLE}

\section{Description}

The Organic Rankine Cycle (ORC) technology is the most commonly used system by industrial facilities to convert low-temperature waste heat into power. The basic cycle consists of a boiler (vaporizer), pump, turbo-generator, condenser, and working fluid (organic fluids such as freons, isobutane, and isopentane). Energy from the waste heat is transferred to the working fluid in the boiler, and then the working fluid vaporizes and enters the electricity production stage. The working fluid vapor rotates the turbine, which is coupled to a generator generating electricity. The working fluid then enters the condenser and travels through a pump to start the cycle again.

Figure 4-1 outlines the WHR process for a simple ORC system. ${ }^{37}$ Energy travels from industrial exhaust to the organic Rankine recovery system, where a generator generates electricity and the remaining energy is rejected to the atmosphere.

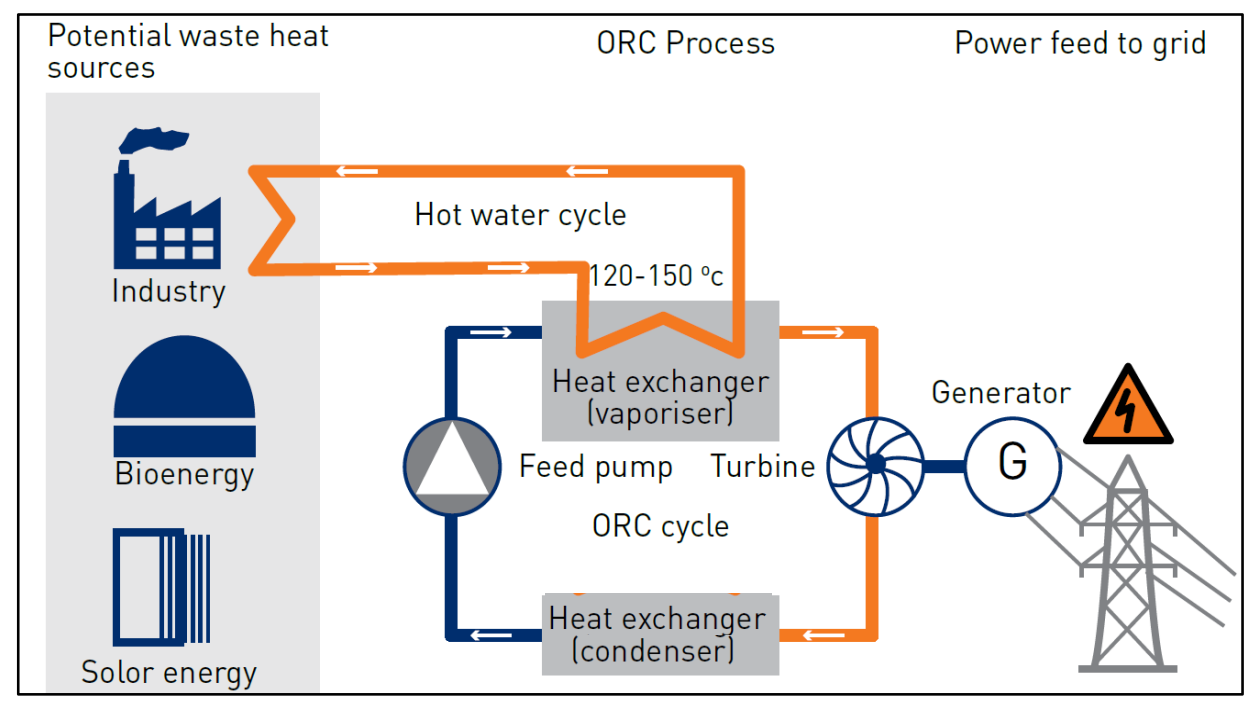

Figure 4-1. Illustration of an industrial ORC technology. 


\section{Advantages}

- Converts waste thermal energy into electrical energy, which can be used in high electricity demand sectors such as manufacturing

- Proven technology (high use in geothermal plants)

- Wide range of power generation or output in terms of kilowatts available

- Many units do not require an operator for monitoring because of remote controlling

\section{Disadvantages}

- Low efficiency $(8 \%-15 \%)^{70}$

- Cost around $\$ 2,000 / \mathrm{kW}-2,500 / \mathrm{kW}^{70}$

- Organic working fluids may pose safety risks

\section{Case Studies}

Two case studies are considered below: a study on the ORC in a biopolymer plant by Rutgers University and a report on ORC in a biogas plant by the Indo-German Forum.

\section{The biopolymer plant}

The powder-making process spans from wet chemical formation to drying the chemicals to form a powder. In the case of biopolymer powders, the ovens used are set at a lower temperature to avoid denaturing the protein structures. Arvay et al. found that a biopolymer dryer produced $9.7 \mathrm{MMBtu} / \mathrm{h}$ of waste heat with a temperature around $240^{\circ} \mathrm{F} .^{68}$

The case study assumed the heat exchanger captures $90 \%$ of waste heat while the ORC converts the rest of the $10 \%$ of waste heat to electricity, producing $250 \mathrm{~kW}$ of power. Using estimates from vendor data, the authors calculated a 2.5 year potential payback time, assuming a $\$ 3,000 / \mathrm{kW}$ system installation cost with a system run-time of 8,000 hours per year and electricity cost of $\$ 0.15 / \mathrm{kWh}$.

Figure 4-2 shows the applicability of different ORC systems with respect to different waste stream temperatures. ${ }^{37}$ As shown, ORCs are applicable with low-temperature waste heat sources whereas steam Rankine cycles are typically used if the waste heat source is higher than $650^{\circ} \mathrm{F}$.

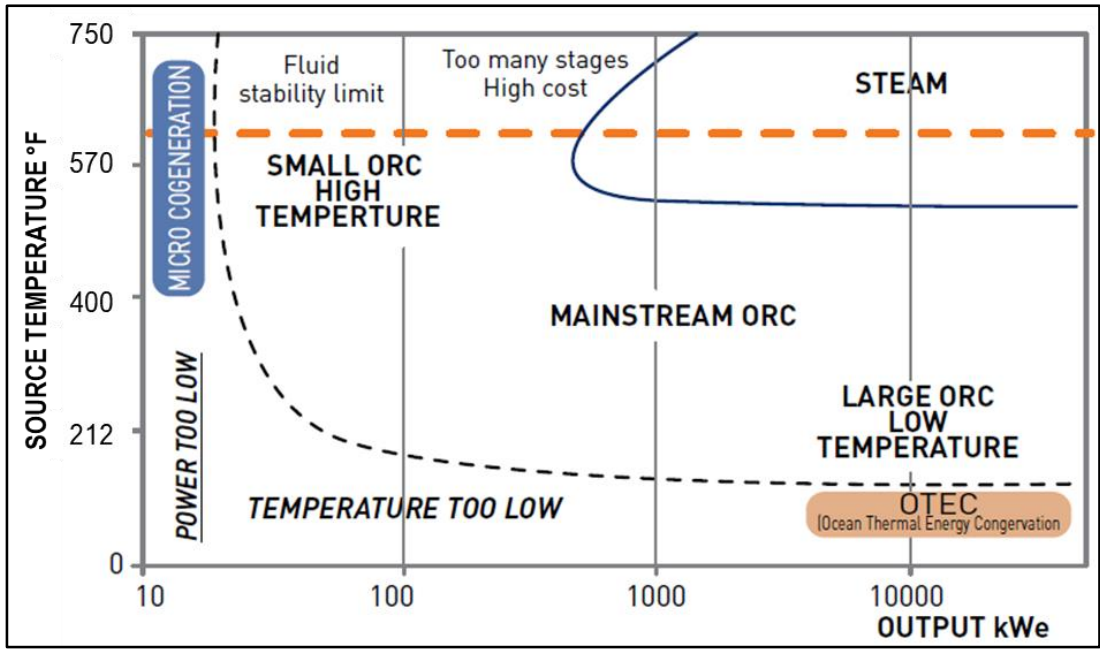

Figure 4-2. ORC applicability based on source temperature and output energy. 


\section{Biogas system}

The biogas system (Figure 4-3) begins with the conversion of biomass into biogas, which enters a CHP system, generating $800 \mathrm{~kW}$ electricity and $333 \mathrm{Btu} / \mathrm{h}$ heat energy. ${ }^{37}$ An ORC system uses the available waste heat from the CHP system to generate another $60 \mathrm{~kW}$ of electricity. The working fluid exits the system at $194^{\circ} \mathrm{F}$. Piping directs this remaining available heat to buildings for space heating and to other operational uses (herb dryers and fermenters).

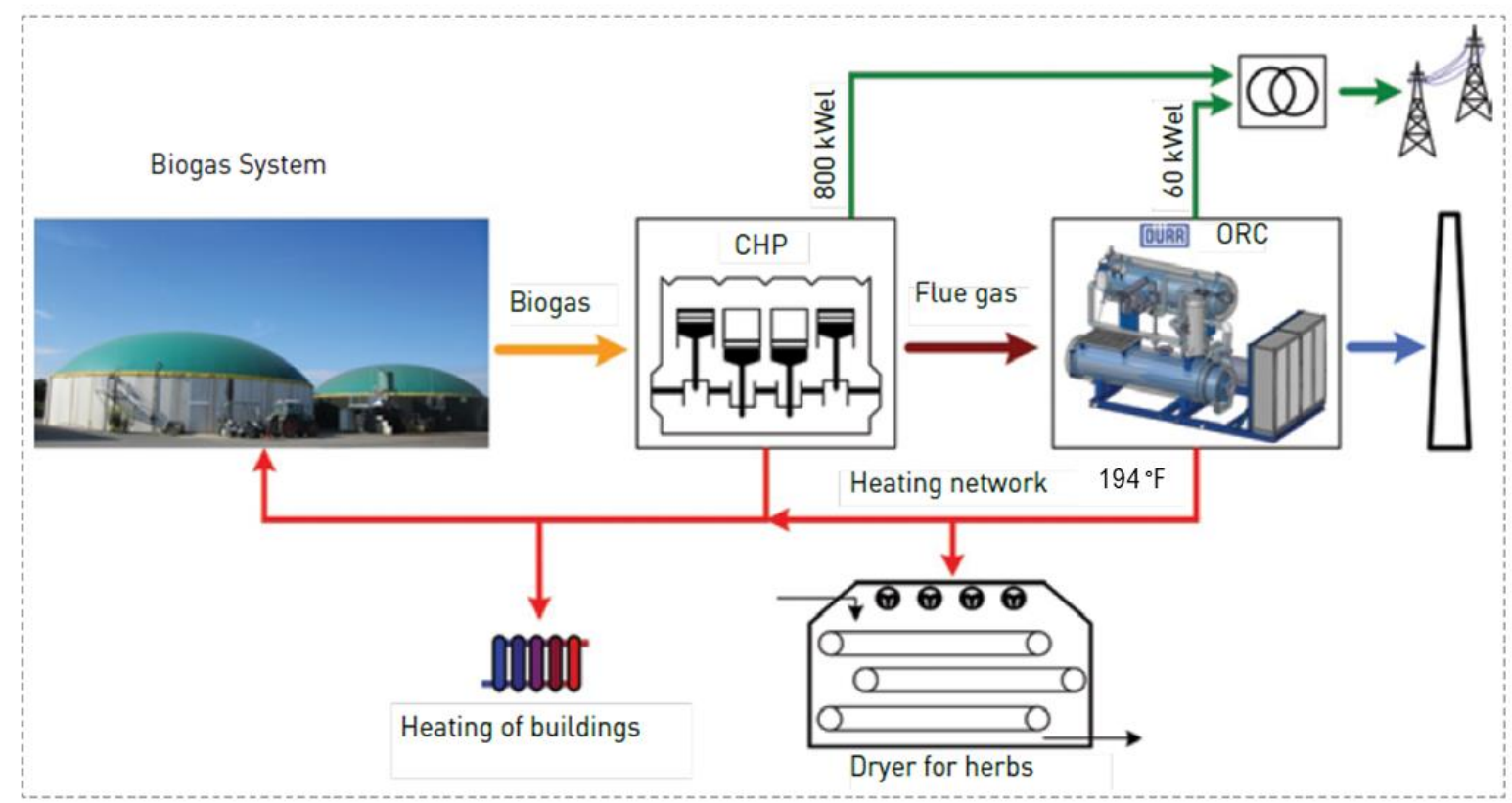

Figure 4-3. The ORC in recovering flue gas from CHP.

The ORC in this system has a payback period of 5 years and an expected lifetime greater than 20 years. The system runs for 7,500 hours per year and the grid buys electricity at approximately $\$ 0.22 / \mathrm{kWh}$. The yearly electricity generation increases from 8.3 million $\mathrm{kWh}$ (without the ORC) to 8.7 million $\mathrm{kWh}$, allowing expansion of the company's clientele.

Several factors aided the economic feasibility of the biogas system WHR project, including the use for exhaust heat content and favorable electricity pricing. Because of the low-temperature nature of many ORC systems, condensates may form from waste gas during the heat exchange between waste gas to ORC system. These deposits typically contain corrosive compounds such as NOx, decreasing the heat exchanger lifespan. Because this system produces its own gas, some degree of control over combustion composition exists to decrease corrosive material in the flue gas. The proximity of buildings, dryers, and fermenters provide further economic viability to the ORC because it eliminates the need for more heat generation and the amount of excess heat. Finally, the buyback electricity price of around $\$ 0.22 / \mathrm{kWh}$ greatly improves the viability of this project because this cost is significantly higher than the average US industrial electricity cost (around $\$ 0.07 / \mathrm{kWh}$ ), providing a shorter payback period.

\subsection{KALINA CYCLE}

\section{Description}

The Kalina cycle has been incorporated into several facilities, largely geothermal electricity generation, with a recent introduction into the cement industry's WHR systems. Similar to an ORC system, the basic 
Kalina cycle consists of a boiler, pump, turbine, generator, condenser, and working fluid (ammoniawater). The working fluid is pumped and then energy from waste heat transfers to the working fluid in the boiler and potentially from other heat exchangers and recuperators. The ammonia-water working fluid expands in the turbine, causing the turbine to rotate. The generator captures this rotation and converts it to electric energy, and the working fluid is cooled in the condenser and begins the cycle again. Figure 4-4 shows a schematic of a Kalina cycle setup. ${ }^{11}$

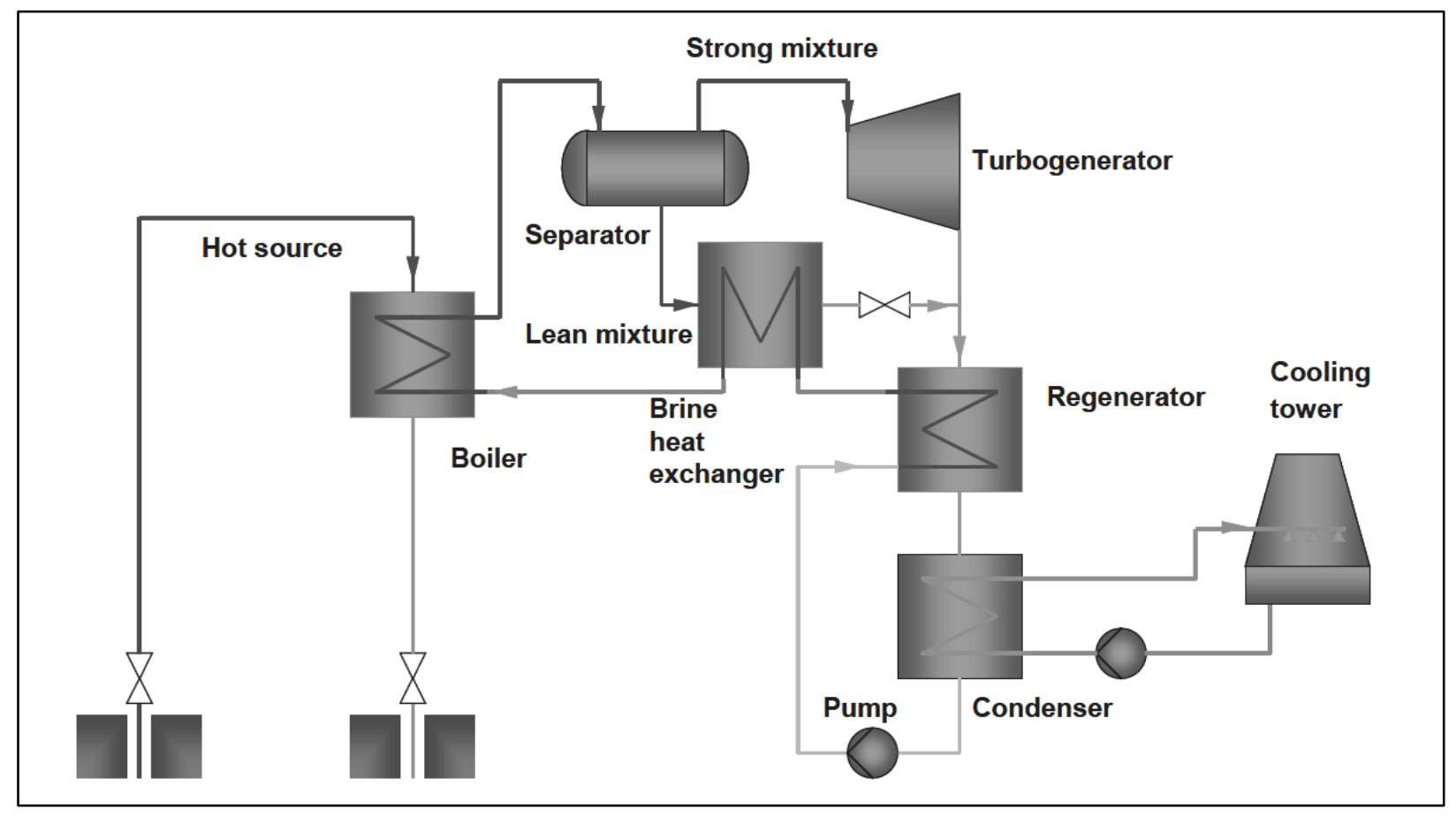

Figure 4-4. Kalina cycle flow schematic.

The ammonia-water composition of the working fluid differentiates the Kalina cycle from steam cycles and ORCs. Its cost varies significantly, with typical prices between $\$ 2,000 / \mathrm{kW}$ and $\$ 3,000 / \mathrm{kW},{ }^{70}$ though prices have been known to dip close to $\$ 1,000 / \mathrm{kW}$. A second generation cycle ${ }^{71}$ was developed by Dr. Kalina and Kalex, LLC, which Dr. Kalina projects to have efficiency and cost improvements. However, it introduces increased complexity through the addition of a number of separators, valves, and pumps.

\section{Advantages}

- Binary working fluid allows better capture of waste heat

- Ammonia-water combination enables the system to capture waste heat streams in a wide temperature range

- Higher efficiency than other Rankine heat recovery systems

\section{Disadvantages}

- More maintenance because of added components and system complexity

- Limited suppliers and experience 


\section{Case Studies}

Kashima Steel Works-enhanced energy efficiency power plant

Since 1999, the Kashima Steel Works plant has operated a 3.45 MW Kalina cycle heat recovery system operating off of previously unused $208^{\circ} \mathrm{F}$ process water. ${ }^{72,75}$ Hoping to generate more revenue from heat recovery than most low-temperature technology could provide, the plant turned to a high-efficiency Kalina cycle WHR system. The original Kalina system designed for use at Kashima Steel Works estimated $60 \%$ greater electric output than the proposed ORC system. ${ }^{75}$ Retaining a capacity factor of $96 \%$, the Kalina cycle recovery system has operated reliably and retained performance and structural integrity. ${ }^{75}$ Turbines are inspected every 4 years and have had no defects. Additionally, the system output exceeds the initial power output design specifications.

The Kashima Steel Works facility was a great candidate for this technology because of its favorable waste stream composition, amount of waste heat, and plant size. The steel plant recovers relatively clean water, whereas other industries must handle corrosives and fouling agents, so large amounts of maintenance costs are avoided. The centrality of the waste heat source resulted in saving on capital and maintenance costs since less ductwork is needed than if the heat was produced in multiple processes. Finally, the size of the waste heat stream, and the facility in general, facilitated the economic viability of the project by achieving an economy of scale from the large output and available capital because of the company size.

\section{Húsavík, Iceland geothermal plant failure}

In 1999, town of Húsavík, Iceland sought a low-cost and high-efficiency WHR system and considered a Kalina system and two ORC systems. They chose the Kalina cycle because of its promised $2 \mathrm{MW}$ output $^{112}$ (an increase of $0.5 \mathrm{MW}$ over the ORC systems) and lower projected cost (around $\$ 4.3$ million).$^{76}$ A pipe connects the geothermal heat source to the Kalina power plant; the power plant uses the geothermal heat to evaporate the cycle fluid and move a turbine generating electricity. Geothermal water enters the Kalina cycle at $250^{\circ} \mathrm{F}$ and exits at $176^{\circ} \mathrm{F}$. The water leaving the system travels to other industrial systems and to houses for district heating.

Table 4-1 shows the Húsavík plant and other existing Kalina power plants. ${ }^{74}$ In 2008, the plant stopped power production to repair the turbine after extensive corrosion. The replacement turbine, made from stainless steel, also failed because of erosion from the fluid flow and from loose structural parts in the fluid. ${ }^{76}$ New Kalina cycle recovery plants should investigate the incident at the Húsavík plant and learn from its failure. The Húsavík plant stopped production in 2008.

Table 4-1. An inventory of Kalina cycle recovery systems.

\begin{tabular}{|c|c|c|c|c|c|c|}
\hline Name & Country & Started & Status & $\begin{array}{c}\text { Output } \\
(\mathbf{M W})\end{array}$ & Heat source & $\begin{array}{c}\text { Source } \\
\text { temperature }\left({ }^{\circ} \mathbf{F}\right)\end{array}$ \\
\hline Canoga Park & USA & 1992 & $\begin{array}{c}\text { Decommissioned in } \\
1997\end{array}$ & 6.5 & $\begin{array}{c}\text { Nuclear waste } \\
\text { heat }\end{array}$ & 959 \\
\hline Fukuoka & Japan & 1998 & $\begin{array}{c}\text { Decommissioned in } \\
2000\end{array}$ & 4 & $\begin{array}{c}\text { Waste } \\
\text { incineration }\end{array}$ & 559 \\
\hline $\begin{array}{c}\text { Sumitomo } \\
\text { Metals }\end{array}$ & Japan & 1999 & Active & 3.5 & Waste heat & 208 \\
\hline Húsavík & Iceland & 2000 & $\begin{array}{c}\text { Acquired for } \\
\text { rurbishment in } \\
2011\end{array}$ & 2 & Geothermal & 250 \\
\hline Fuji Oil & Japan & 2005 & Active & 3.9 & Waste heat & 244 \\
\hline
\end{tabular}




\begin{tabular}{|c|c|c|c|c|c|c|}
\hline Name & Country & Started & Status & $\begin{array}{c}\text { Output } \\
(\mathbf{M W})\end{array}$ & Heat source & $\begin{array}{c}\text { Source } \\
\text { temperature }\left({ }^{\circ} \mathbf{F}\right)\end{array}$ \\
\hline Bruschal & Germany & 2009 & Active & 0.6 & Geothermal & 244 \\
\hline Unterhaching & Germany & 2009 & Active & 3.5 & Geothermal & 252 \\
\hline Shanghai Expo & China & 2010 & $\begin{array}{c}\text { Decommissioned } \\
\text { after expo }\end{array}$ & 0.05 & Solar hot water & 198 \\
\hline Quingshui & Taiwan & 2011 & Active & 0.05 & Geothermal & 230 \\
\hline Khan Cement & Pakistan & - & Under construction & 8.5 & $\begin{array}{c}\text { Waste heat } \\
\text { (cement) }\end{array}$ & - \\
\hline Start Cement & UAE & - & Under construction & 4.8 & $\begin{array}{c}\text { Waste heat } \\
\text { (cement) }\end{array}$ & - \\
\hline
\end{tabular}

\subsection{SUPER CRITICAL $\mathrm{CO}_{2}$ CYCLE}

\section{Description}

The $\mathrm{sCO}_{2}$ cycle uses $\mathrm{CO}_{2}$, which has a relatively low critical temperature and pressure compared with working fluids in either a Rankine- ${ }^{1}$ or Brayton-based system. The supercritical fluid bypasses the isothermal liquid-vapor phase change region, allowing better thermal match with the heat source. This decreases irreversibility and increases efficiency over the conventional Rankine cycle and essentially eliminates any noticeable pinch point. Figures 4-5 and 4-6 show a typical $\mathrm{sCO}_{2}$ system setup. ${ }^{78}$

The basic cycle consists of a turbine, compressor, recuperator, cooler, and $\mathrm{CO}_{2}$. Energy from the waste heat stream transfers to the working fluid $\left(\mathrm{CO}_{2}\right)$, which evaporates and enters the turbine. The turbogenerator combination then converts mechanical energy to electrical energy. The recuperator then preheats the $\mathrm{CO}_{2}$ liquid from the condenser to complete the cycle. ${ }^{1}$

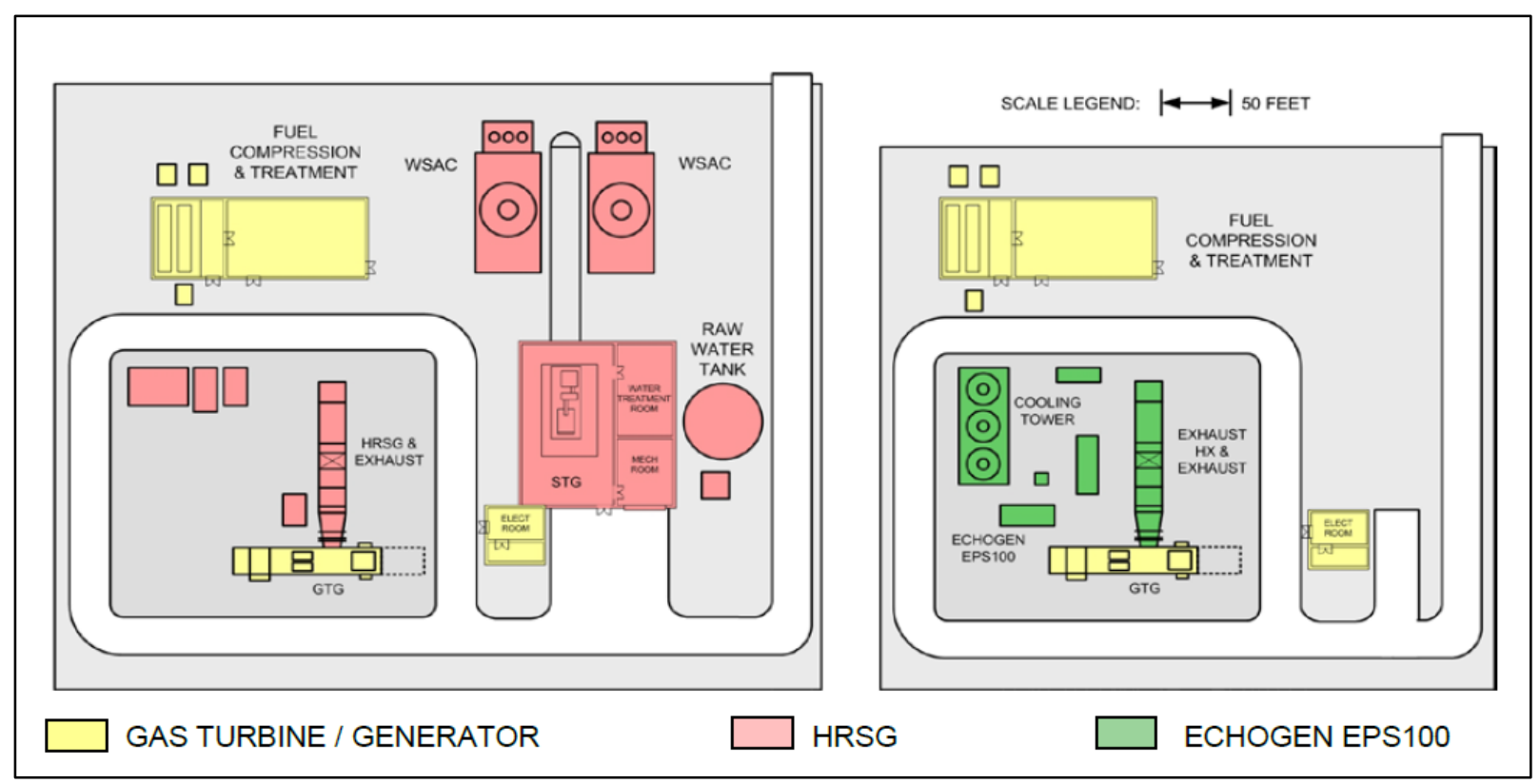

Figure 4-5. Plant size comparison between a $\mathrm{SCO}_{2}$ system and a steam Rankine system. 


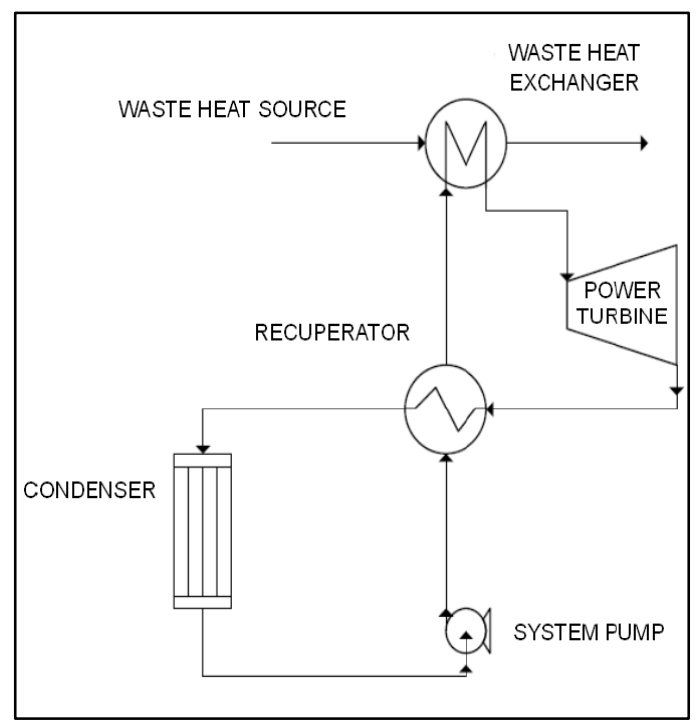

Figure 4-6. Flow schematic for a simple $\mathrm{sCO}_{2}$ cycle system.

\section{Advantages}

- Better thermal match with the heat source

- $\mathrm{CO}_{2}$ is nontoxic, is nonflammable, and has a low environmental impact ${ }^{31}$

- Projected $15 \%-25 \%$ lower cost than ORC recovery system ${ }^{77,31}$

- Capable of handling cyclic operation without thermal fatigue or corrosion ${ }^{78}$

\section{Disadvantages}

- New technology with little commercial development ${ }^{31}$

- Potential maintenance issues ${ }^{31}$

- High pressure necessary to operate

\section{Case Studies}

Echogen is one of the companies developing and demonstrating $\mathrm{sCO}_{2}$ cycle technology for industrial users. Many of these demonstrations are meant to illustrate the advantages of $\mathrm{sCO}_{2}$ over other commercial systems and alleviate concern over the system pressure. Two of Echogen's demonstration projects, WHR on a naval vessel and for a municipal district heating, are discussed below.

\section{Echogen Navy heat recovery system}

In 2011, Echogen completed a Phase I small business innovative research project for the US Navy to develop initial models and testing for $\mathrm{sCO}_{2}$ WHR on Navy vessels. Tests of the produced system showed a fuel reduction of around 20\% while occupying minimal space (an important factor considering the confined space on board). This success paved the way for continued work with the US Navy through a Phase II small business innovation research project. Also, Echogen signed an agreement with GE Marine to be the exclusive provider of heat-to-power system for use on commercial and military marine vessels worldwide. $^{78,79}$

System pressure and leaks are important safety considerations for these systems. The high operating pressure of a $\mathrm{sCO}_{2}$ system causes increased stress on components and thus component wear. High internal 
stress can be mitigated through materials selection, system design, and a regular maintenance schedule. If not properly maintained, leaks could cause large amounts of $\mathrm{CO}_{2}$ to escape. Because $\mathrm{CO}_{2}$ is heavier than air, build-up could occur, creating a toxic atmosphere if the area is not properly ventilated. Levels between $2 \%$ and $10 \%$ can cause mental and physical discomforts and temporary impairments, and concentrations exceeding $10 \%$ can be fatal if exposed for several minutes. ${ }^{80}$

\section{Echogen field testing in Groveport and Akron, Ohio}

From 2010 to 2011, Echogen tested eight turbo-alternator configurations at a test site in Groveport, Ohio (Figure 4-7). ${ }^{81}$ Heat from a natural gas-fired system was provided via a heat transfer fluid in place of flue or exhaust gas for 80 days of operation with more than 85 system starts. Results from this year-long test included an increased power rating from 250 to $400 \mathrm{~kW}$ and development of two turbine configurations for endurance testing. ${ }^{78,81}$

After the Groveport testing, the system and additional plant hardware were transported to the Akron Energy Systems municipal district heating facility for long-term testing of component durability and system response to seasonal change. Echogen agreed to production of another test facility in New York with the Dresser-Rand Corporation. ${ }^{81}$

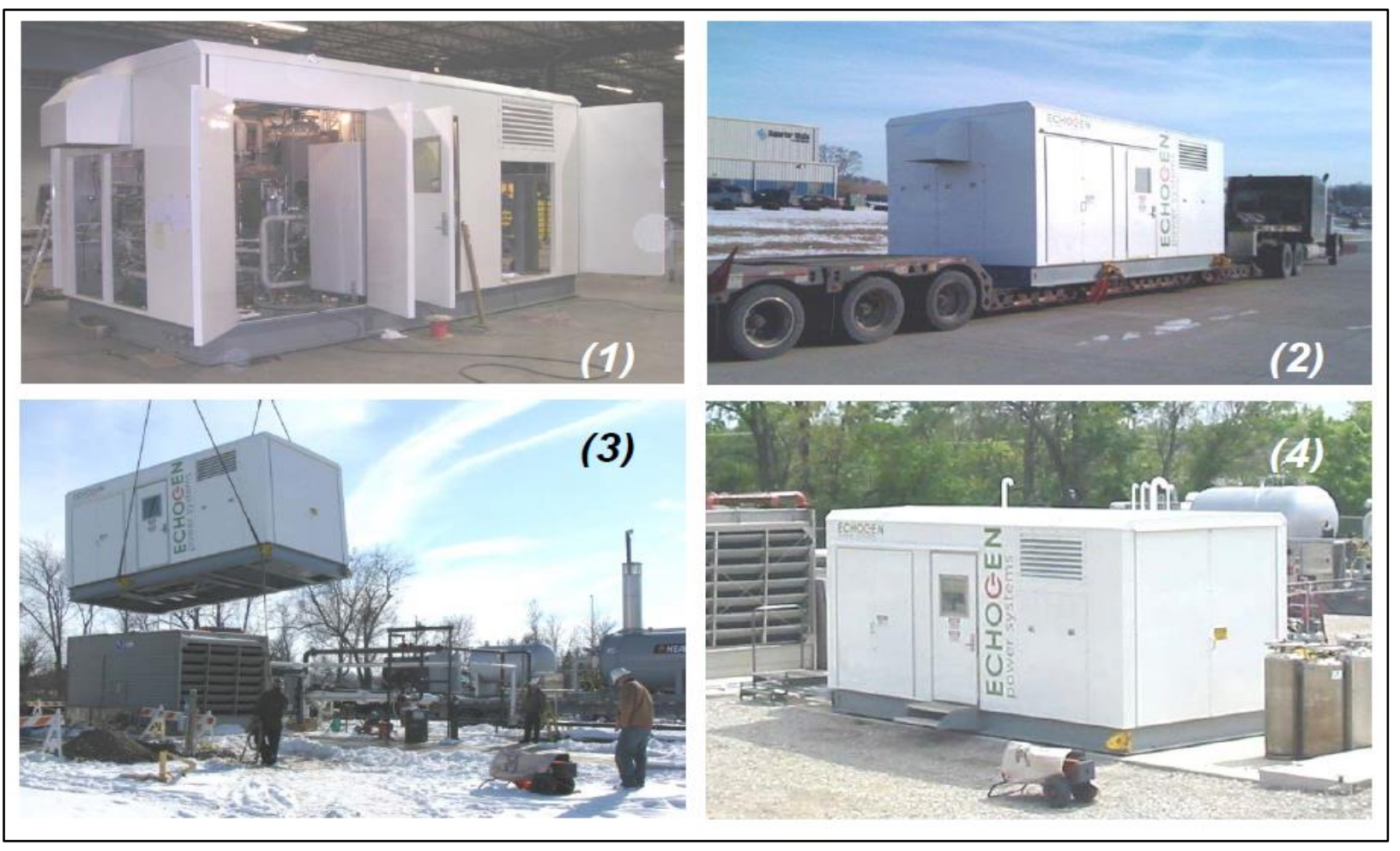

Figure 4-7. (1) Assembling, (2) shipping, (3) installing, and (4) testing of a $\mathrm{SCO}_{2}$ system in Groveport, Ohio.

\subsection{TRILATERAL FLASH OR VARIABLE PHASE CYCLE}

\section{Description}

A generic variable-phase cycle contains a pump, liquid heat exchanger, turbine, and condenser. The working fluid (refrigerant) is pressurized and transferred to the heat exchanger after which the fluid flashes in the vaporizer and turbine. ${ }^{82}$ The key to this cycle is the vaporization of the working fluid 
because vapor has a lower density, which leads to higher energy transfer from the working fluid to the turbine. The turbine rotates and connects to a generator converting mechanical energy to electrical energy. The fluid is then condensed and cycled back through the system. ${ }^{82}$

Energent manufactures a variable-phase cycle system to convert geothermal heat to electrical energy and has created a system for recovering waste heat from large ship engines. Additionally, Energent has been operating a $1 \mathrm{MW}$ variable phase geothermal power plant. ${ }^{83}$ From this project, Energent estimates the system cost to be $\$ 2,500 / \mathrm{kW} .{ }^{84}$ One of the benefits of this system is the variable-phase turbine, which can efficiently expand the multiphase fluid with minimal erosion. Among other improvements, many highmaintenance parts, such as the waste heat boiler, gearbox, seals, and lube system, are eliminated. ${ }^{85}$

Energent has operated a $1 \mathrm{MW}$ geothermal power plant, where the only significant issue was solved by changing heat exchanger type.$^{86}$ Given temperature of previously used sources, this technology should not have any significant issues transitioning to low-temperature waste heat to power. The system has been used in chilling operations with 7-8\% efficiency improvements over two phase expansion valves ${ }^{85}$. A simple setup of a variable-phase cycle (VPC) system is shown in Figure 4-8. ${ }^{87}$

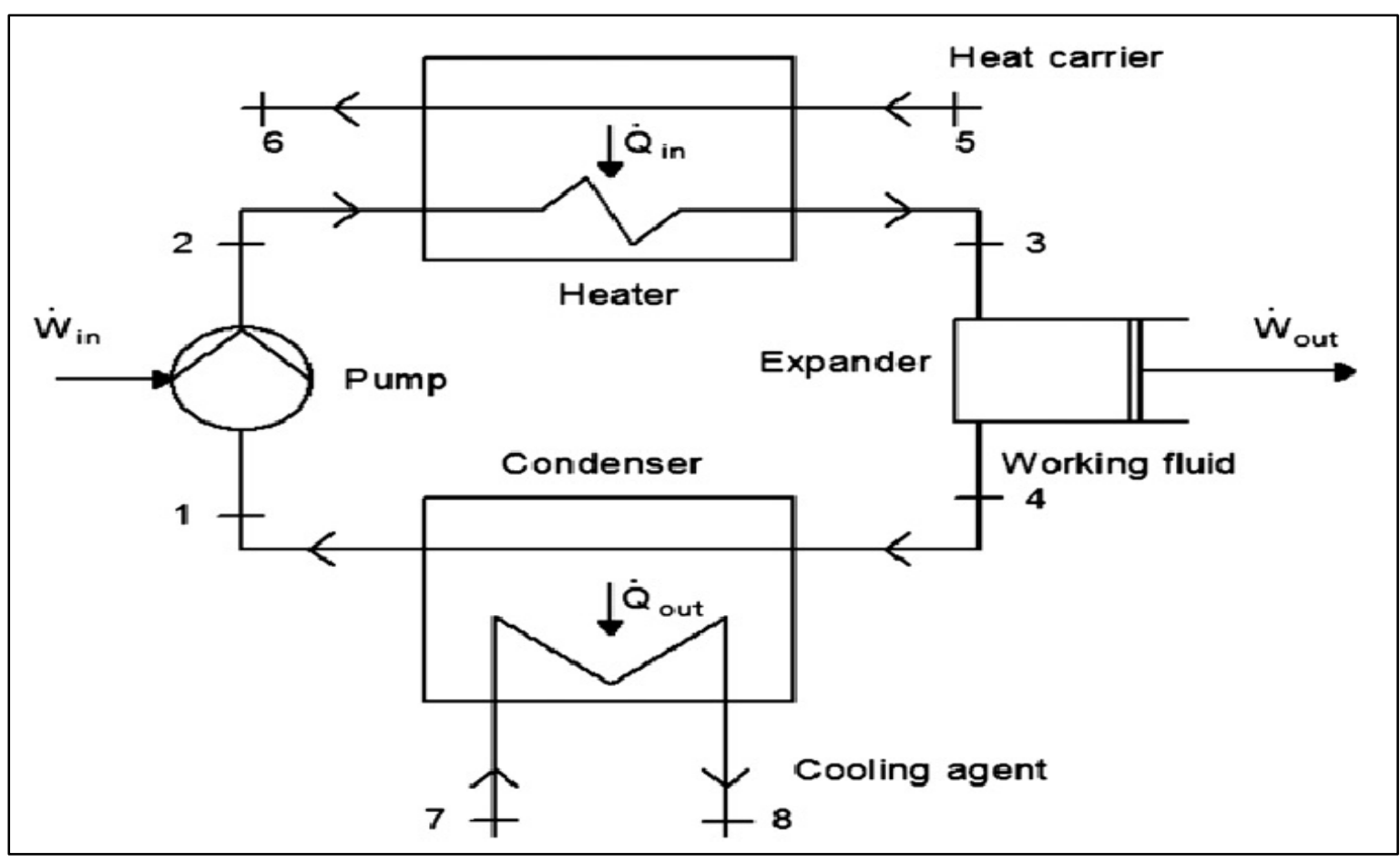

Figure 4-8. Schematic of a simple VPC system.

\section{Advantages}

- $20 \%-40 \%$ increase in power output over ORC

- Decreased maintenance cost from the elimination of several parts

\section{Disadvantages}

- New technology with limited industrial development

- Requires a high flow rate of working fluid ${ }^{87}$ 


\subsection{PHASE CHANGE MATERIAL ENGINE}

\section{Description}

When undergoing phase change, materials exhibit an associated volumetric change. The phase change material (PCM) engine uses this fundamental property of materials to convert volumetric change in materials to electricity. The PCM used in the engine is paraffin, which expands and contracts when heated or cooled. Two pumps control the feed temperature to the PCM by alternating between feeding liquid waste heat and cooling fluid streams. The work of expansion and contraction is captured in a hydraulic system and converted to electricity by a generator. ${ }^{88} \mathrm{~A}$ schematic of a PCM engine system is shown in Figure 4-9.

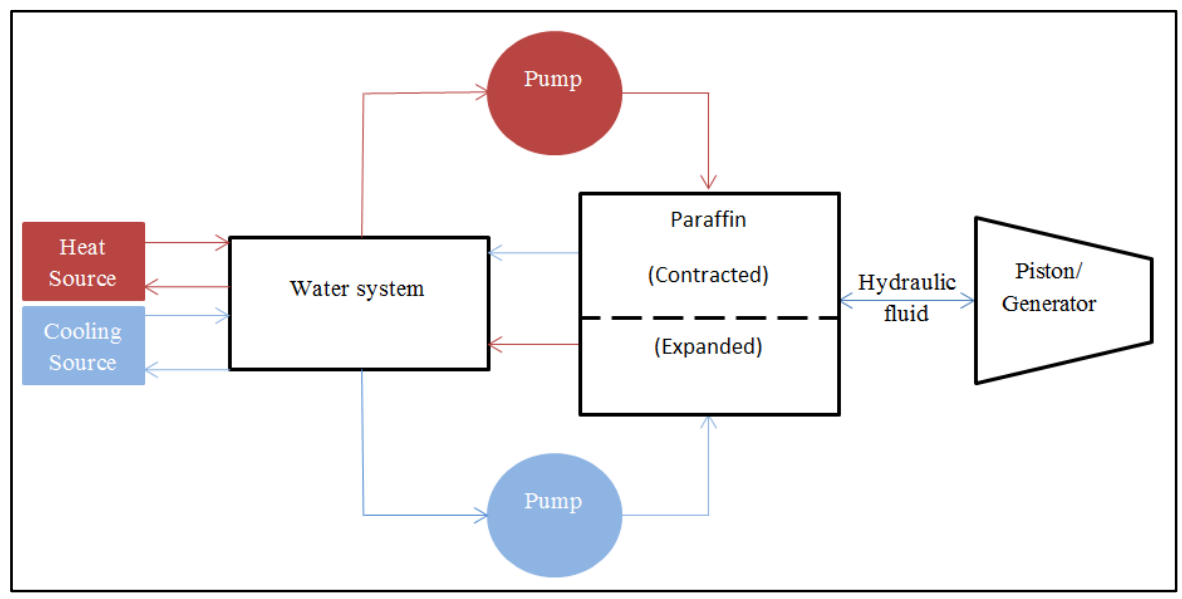

Figure 4-9. Schematic view of a PCM engine system.

Exencotech $\mathrm{AB}$ is a producer of PCM engines. The projected price of one of these systems is expected to drop from the current $\$ 3,300 / \mathrm{kW}$ to $\$ 2,200 / \mathrm{kW}$ in the near future because of ongoing paraffin research. Installation and O\&M costs are expected to be low, and electrical output capabilities are expected to range from $25 \mathrm{~kW}$ to $1 \mathrm{MW}$. A test system is being developed for third-party testing. ${ }^{89}$

\section{Advantages}

- Converts very low-temperature waste heat $\left(77^{\circ} \mathrm{F}-140^{\circ} \mathrm{F}\right)^{89}$

\section{Disadvantages}

- New technology with little commercial development ${ }^{66}$

- Low heat to electricity efficiency

\subsection{THERMOELECTRIC GENERATION}

Thermoelectric generators (TEGs) convert waste heat energy directly to electrical energy, unlike other waste heat devices that first need to convert waste heat into another form of energy (e.g., mechanical) before producing electrical energy. This technology is enabled by the Seebeck effect, the phenomenon of a thermal gradient across a material producing electron flow and thereby creating voltage ${ }^{90}$ Figure $4-10$ shows a typical setup of a TEG system. ${ }^{13}$ When heat is applied to one end, the charge carriers move away to the colder side and accumulate on the cold side. This buildup of charge at one end creates a voltage potential, which is directly proportional to the temperature difference between the hot and cold side. 
Stacking up of several n-type and p-type semiconductors will result in greater voltage or power generation potential.
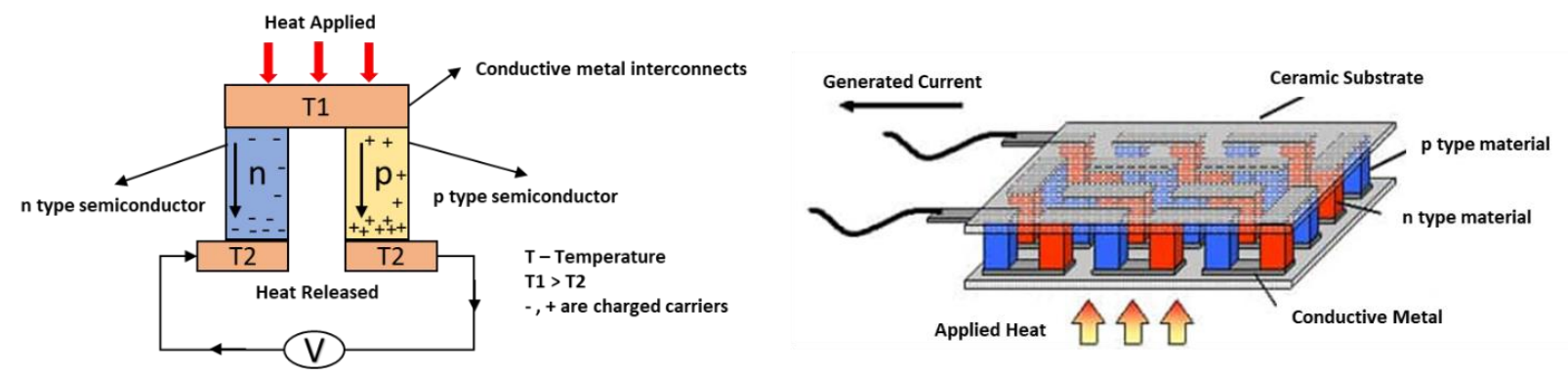

Figure 4-10. Schematic view of a TEG system setup.

For industrial waste heat applications, this technology largely remains in the laboratory development stage, though there is at least one high-temperature commercial device. ${ }^{\text {Error! Bookmark not }}$

defined.Thermoelectric waste heat generation has two main advantages over other system types: scalability and rugged design. Most TEG systems are composed of small modules, allowing an easy transition from small to large scale. As a consequence of its scalability, TEGs have generated interest from the automotive industry to recover car exhaust, thus providing a funding opportunity for further development. Additionally, since TEGs contain no moving parts, longer lifetimes are achievable, and less maintenance is needed..$^{90}$

The low operational temperature, efficiency, and high materials cost are major barriers for commercial development of TEGs. Current thermoelectric materials often require temperatures near $500^{\circ} \mathrm{F}$ to operate at optimal efficiency with low-grade heat sources. Efficiency of a TE system is relatively low, usually in the range of $2 \%$ to $5 \%$, which does not produce enough electricity to economically justify the purchase. However, recent advances in nanotechnology have increased the generation efficiency to $15 \%$ or higher. $^{10}$ The most commonly used thermoelectric material, bismuth telluride, is moderately rare and costly, pushing pricing to around $\$ 13,000 / \mathrm{kW}$ as opposed to other systems, which are usually priced at $\$ 2,500 / \mathrm{kW} .{ }^{90}$

Further research into improved thermoelectric material is necessary to make TEGs economically feasible for low temperatures. For example, Phononic Devices aims to improve the thermoelectric device efficiency to $30 \%$ using silicon nanowires.$^{91}$ Other research to improve economic and technical viability of TEG systems includes research at the University of Illinois in stacked silicon nanotube thermoelectric array and carbon nanotube-polymer thin films at Wake Forest University. ${ }^{92,93}$

\section{Case Study}

Alphabet Energy, Inc.

In October 2014, Alphabet Energy, Inc. introduced a TEG product called "E1," which is essentially a generator that uses thermoelectric generation instead of fuel to generate power. The E1 takes waste heat from industrial machines such as engines and generators. The waste heat can be directed through a flexible tube to the E1 generator. The E1 generator is made of 32 racks of thermoelectric modules and is designed in such a way that its components can be switched to another material as materials technology advances. The materials used in the E1 are the p-type tetrahedrites and the n-type magnesium silicide. ${ }^{30}$ Alphabet Energy claims that if exhaust from an engine that generates $1,000 \mathrm{~kW}$ of electricity from a diesel fuel is applied to the E1, it can produce close to $25 \mathrm{~kW}$ power. ${ }^{73}$ 


\subsection{THERMIONIC GENERATOR}

Thermionic generator operates in a similar fashion to TEGs in which electric current is produced from the difference in temperature between two media and without any moving parts. In case of a thermionic generator, as seen in Figure 4-11, ${ }^{29}$ a temperature difference between two electrodes (emitter and collector) generates flow of electrons in an interelectrode space (vacuum, vapor, or plasma) to generate electricity.

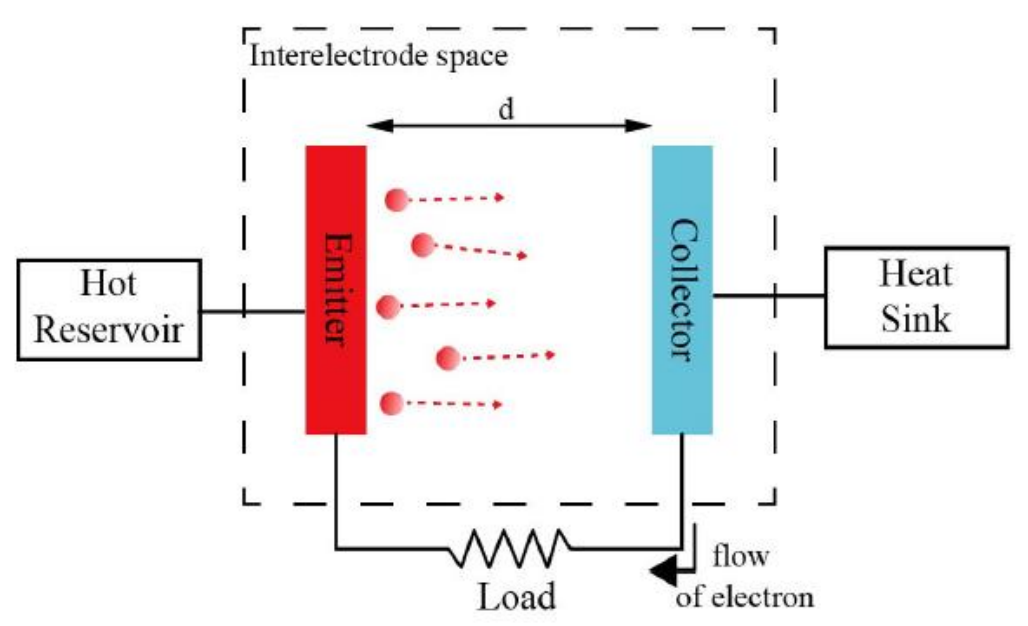

Figure 4-11. Schematic view of a thermionic generator.

Thermal energy is applied by the heat source to the electrons inside the emitter and the collector is attached to the heat sink to remove the heat from the collector. As thermal energy is applied, the electrons in the emitter get energized. Once sufficient heat energy is applied, the electrons start moving out from the emitter, making their way to the colder collector travelling through an interelectrode space. The negative charge accumulated in the collector will induce a voltage difference between the two electrodes generating an electric current. The flow of electrons or electricity will continue as the electrons travel between the emitter and collector. The functionality of this technology is shown to be inefficient and limited to high-temperature applications, but several attempts have been made to improve the efficiency and enable use for low-temperature applications. ${ }^{10}$ The efficiency of thermionic generators ranges between $10 \%$ and $20 \%$, which is slightly better than the TEG range. ${ }^{28,13}$

\subsection{PIEZOELECTRIC GENERATION}

Piezoelectric generation systems convert heat to electrical energy through small pressure differences applied to the piezo material. Exhaust heat transfers to pressurized helium, causing it to vibrate. The helium working fluid continues to vibrate as it passes the piezoelectric generator, where it provides pressure and produces mechanical energy. The piezo material then converts this mechanical energy to electrical energy.

Research to improve these systems largely relies on improving the piezoelectric material properties. The largest barriers for commercialization of piezoelectric generators for waste heat are efficiency, reliability, and cost. Piezoelectric generation systems efficiency hovers around $1 \%$ and needs significant improvement to achieve market presence. Lab tests show less than 1 year of reliable production for current piezoelectric generation systems, far short of the 20 or more years of most commercial systems. ${ }^{1}$ Laboratory setups for piezoelectric generation systems cost $\$ 10,000 / \mathrm{W},{ }^{1}$ which would result in extremely lengthy payback periods when compared with commercial WHR systems around \$2/W- $\$ 3 / \mathrm{W}$. 


\subsection{TRANSPORT MEMBRANE CONDENSER}

Transport membrane condenser (TMC) technology was developed from the DOE research project "Advanced Energy and Water Recovery Technology from Low-Grade Waste Heat." In this process, flue gas flows through the TMC, where latent heat and sensible heats are recovered along with water vapor. The water vapor from the waste heat is condensed in pores on the membrane and wicked through the tube wall, providing heat and water to preheat the cold makeup water. Figure 4-12 shows the TMC setup placed in a duct, where flue gas passes through the tubes. ${ }^{31}$

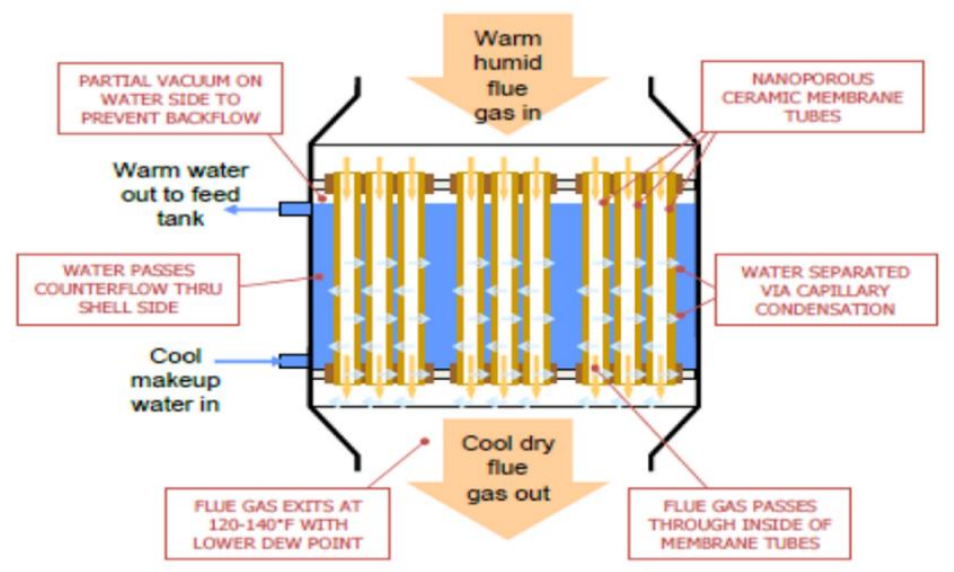

Figure 4-12. Schematic view of TMC system components.

The transport membrane technology could recover low-temperature waste heat from calciners, limekilns, recovery boilers, and post-cleaning processes. Advantages of TMCs include compact design, corrosion resistance, modular design, water recovery, and cost-effectiveness. For a boiler heat recovery application, the TMC had a payback period of 2 years. More tests in industrial settings will improve the TMC system and introduce the technology to industry. During tests under normal operating conditions, no condensate formation was noted within the stainless steel TMC enclosure. Commercialization has begun for TMCs with implementation in boilers as an initial market introduction..$^{52,94,95}$

Figure 4-13 compares the discussed technologies and their waste heat operating temperature ranges.

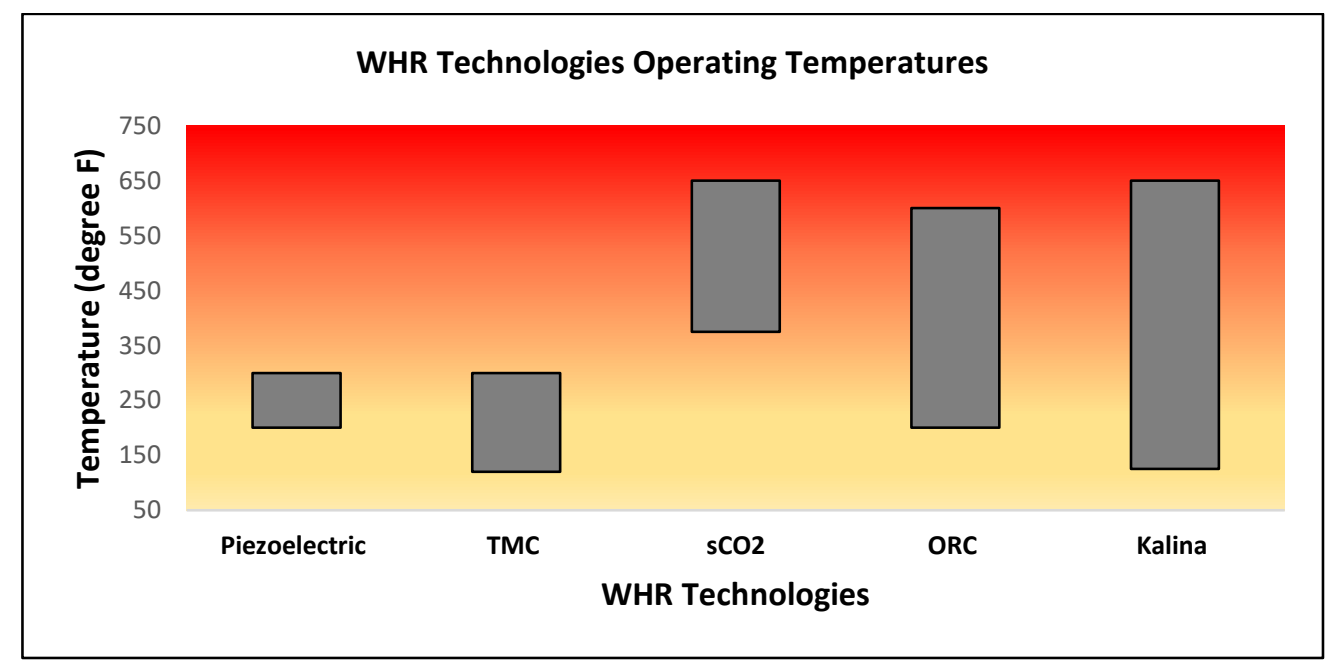

Figure 4-13. Comparison of industrial waste heat temperatures and WHR technology operating temperatures. 


\subsection{MICROBIAL HEAT RECOVERY}

Microbial heat recovery cell development began in 2012 with funding from the DOE Advanced Manufacturing Office. The cell designed to use WHR operates as a fuel cell and converts wastewater effluent streams into electric power or hydrogen. The driving force for the release of electrons is the energy that is captured using the concentration difference between the high-salinity and low-salinity streams. The bacteria present in wastewater oxidizes organic matter and release electrons to an electrode (anode), which passes to a counter-electrode (cathode) producing an electric current.

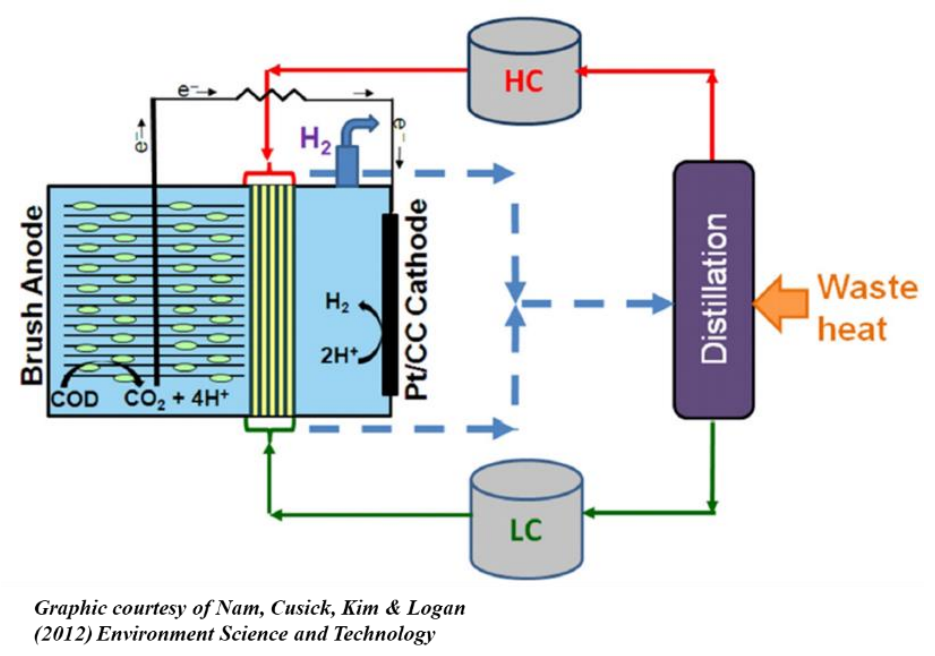

Figure 4-14. Schematic view of a TMC system components. HC = high salinity; LC = low salinity.

The technology is still in the R\&D phase but could save 40 TBtu and 6 million tons of carbon emissions annually. This technology is expected to salvage heat streams that are considered to be at temperatures too low for WHR. Additionally, microbial heat recovery is expected to have higher efficiency, higher yield, and a smaller footprint than conventional WHR, with likely applications in the pulp and paper industry and chemical, food, pharmaceutical, and refinery markets. The system can be retrofitted into existing plant operations; however, scaling up this technology, along with the cost for the ion exchange membrane, remains problematic for commercialization and implementation. ${ }^{96}$ Initial systems would likely be for low-volume heat applications because of scalability.

\subsection{STIRLING ENGINE}

The ideal Stirling cycle is composed of four simple steps: isothermal compression, isovolumetric heating, isothermal expansion when electricity is generated, and isovolumetric cooling. Because of the cycle's near approximation to the Carnot cycle, research interest in Stirling engines has renewed in recent years, especially in the low-temperature regime, despite historically low efficiencies. The general focus of recent research has involved low-temperature differential Stirling engines, solar energy conversion, different general designs (e.g., alpha, beta, gamma), and the more precise analysis of actual system thermodynamics. ${ }^{97,98,99,100,101}$ Furthermore, other potential areas of use are being investigated, including industrial waste heat. Electric output of these systems is typically in the range of a few to tens of kilowatts, though there is some research into the potential for megawatt-scale systems. Unfortunately, achieved efficiencies remain significantly below the theoretical potential of such systems. 


\subsection{THERMAL STORAGE}

One of the factors inhibiting further implementation of WHR systems is the intermittent nature of waste heat provided by many processes. If the waste heat is cascaded down to a lower-temperature process, product quality could vary because of fluctuating temperatures or require a heat source to fluctuate opposite of the waste heat cycle. Alternatively, if the electricity is produced from the heat, energy could be lost through the need to start and stop the generation cycle. One potential solution to this issue is coupling thermal storage technology, or the use of materials to capture, hold, and later release thermal energy with waste heat to power or other continuous heating processes.

The three main categories of thermal storage are sensible, latent, and thermochemical. Sensible storage involves using a material's heat capacity to store and release thermal energy, and latent storage uses a material's latent heat of formation caused by a phase change. Latent heat systems also use sensible storage, but the temperature range is generally insufficient for this to be considered significant when compared with the heat of formation. Thermochemical storage uses chemical bonds as a means of storing energy, typically through sorption/desorption cycles or by separating the products of a chemical reaction that will later react to release heat. Although the most widely used of the three is sensible heat storage, thermochemical storage offers the highest energy storage density. ${ }^{43,102,103}$

\subsection{LOW-TEMPERATURE WASTE HEAT TECHNOLOGIES SUMMARY}

In this section, several tables are presented to summarize the discussed conventional and upcoming WHR systems, as well as several others that were not explicitly outlined in this report. Tables 4-2, 4-4, and 4-5 contain inventories of most available or emerging heat recovery technologies. Table 4-2 focuses on waste heat to power technologies, and Table 4-4 considers waste heat recycling technologies. Both tables show the advantages and disadvantages of the technologies, which helped narrow down the technologies of interest to this report. Selected areas of improvement for ORC, with a focus on efficiency or cost, are discussed in Table 4-3. Emerging technologies and those in the research phase are described in Table 4-5, and they have promising commercial appeal. WHR systems are further categorized based on operating temperature, efficiency, cost, future potential, and current development. ORC and Kalina cycles were identified to be the commonly used low temperature WHR systems. 
Table 4-2. Current waste heat to power technology inventory.

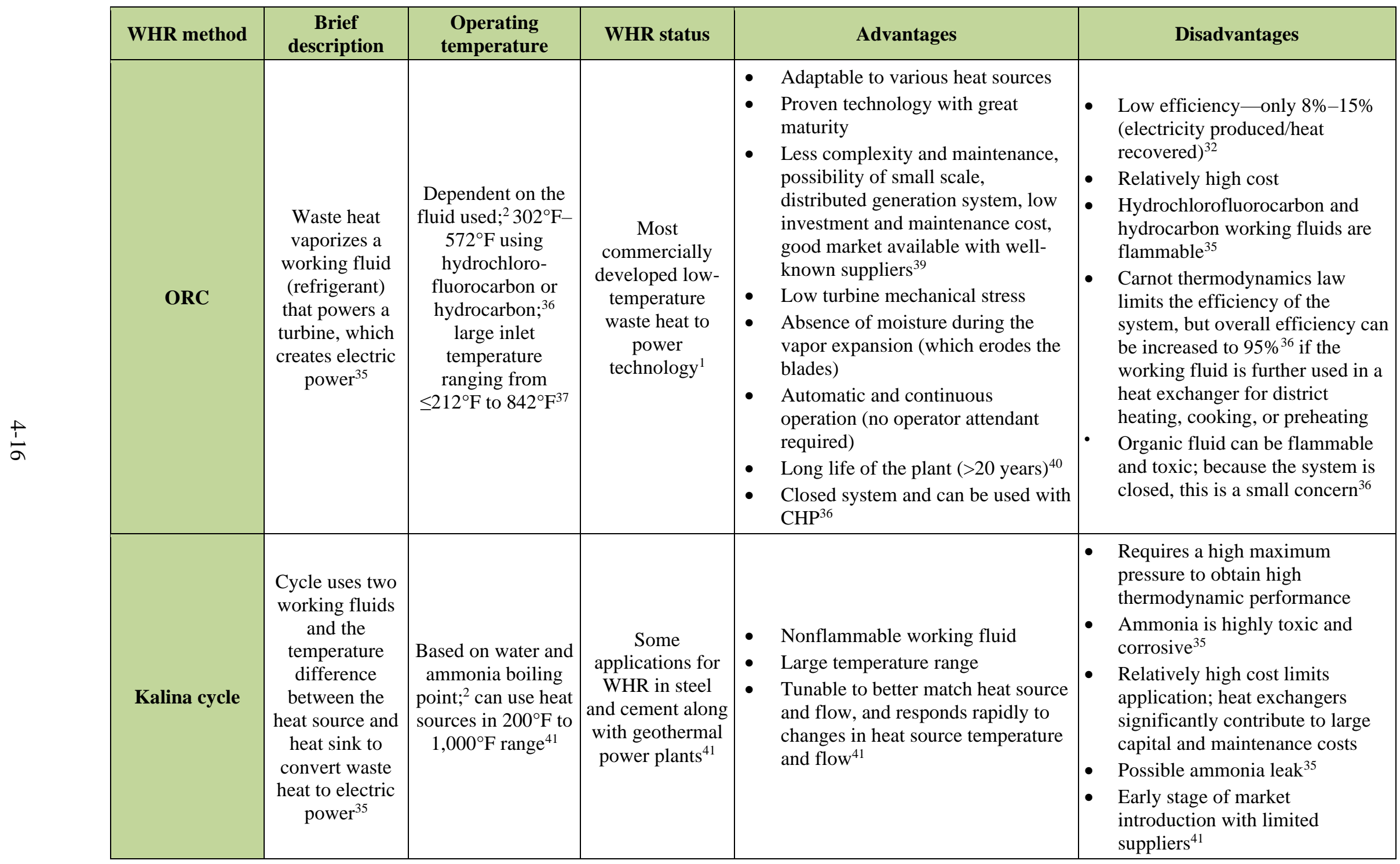


Table 4-2. Current waste heat to power technology inventory (continued).

\begin{tabular}{|c|c|c|c|c|c|}
\hline WHR method & $\begin{array}{c}\text { Brief } \\
\text { description }\end{array}$ & $\begin{array}{c}\text { Operating } \\
\text { temperature }\end{array}$ & WHR status & Advantages & Disadvantages \\
\hline $\begin{array}{c}\text { Thermoelectric } \\
\text { generation }\end{array}$ & $\begin{array}{l}\text { Semiconductor } \\
\text { solids use } \\
\text { temperature } \\
\text { difference to } \\
\text { create electrical } \\
\text { energy }^{2}\end{array}$ & $\begin{array}{l}\text { Dependent on } \\
\text { thermoelectric } \\
\text { material; potential } \\
\text { for low, medium } \\
\text { and high } \\
\text { temperature }^{43}\end{array}$ & $\begin{array}{l}\text { High- } \\
\text { temperature } \\
\text { systems } \\
\left(>900^{\circ} \mathrm{F}\right) \\
\text { entering } \\
\text { market; }{ }^{42} \text { more } \\
\text { R\&D needed for } \\
\text { feasible low- } \\
\text { grade heat } \\
\text { recovery }\end{array}$ & $\begin{array}{l}\text { - No moving parts (no/low } \\
\text { maintenance costs) } \\
\text { - Can be used in unmanned sites } \\
\text { - Smaller thermoelectric cells (can } \\
\text { use in space constrained } \\
\text { applications) } \\
\text { - } \\
\text { Potential for integration with other } \\
\text { power systems }{ }^{44}\end{array}$ & 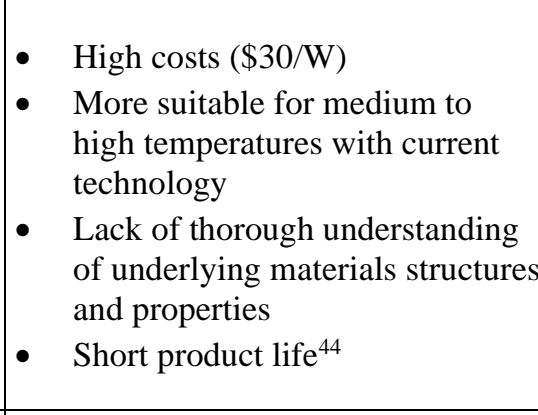 \\
\hline $\mathrm{sCO}_{2}$ cycle & $\begin{array}{l}\mathrm{sCO}_{2} \text { working } \\
\text { fluid is expanded } \\
\text { to generate } \\
\text { mechanical } \\
\text { energy in } \\
\text { turbine; then, } \\
\text { generator } \\
\text { converts } \\
\text { mechanical to } \\
\text { electric energy }\end{array}$ & $\begin{array}{l}\text { Approximately } \\
390^{\circ} \mathrm{F}-930^{\circ} \mathrm{F}^{45}\end{array}$ & $\begin{array}{c}\text { Some } \\
\text { applications but } \\
\text { not widely used }\end{array}$ & $\begin{array}{l}\text { - Low environmental impact }{ }^{46} \\
\text { - Nontoxic, naturally abundant, and } \\
\text { inexpensive working fluids }{ }^{43} \\
\text { - Efficient heat exchange } \\
\text { - } \\
\text { Compact turbomachinery }\end{array}$ & $\begin{array}{ll}\text { - } & \text { High cost }(\geq \$ 2000 / \mathrm{kW})^{36} \\
\text { - } & \text { Higher pressures than most other } \\
\text { waste heat to power systems } \\
\text { - } \begin{array}{l}\text { Not as thoroughly researched as } \\
\text { many other Rankine-related } \\
\text { systems }^{38}\end{array}\end{array}$ \\
\hline
\end{tabular}

Table 4-3. Current research into ORC improvements.

\begin{tabular}{|c|c|}
\hline Improvement name & Improvement description \\
\hline $\begin{array}{l}\text { Internal heat } \\
\text { exchanger }\end{array}$ & Improves the transfer of heat in subcritical and low-pressure stages of supercritical ORC ${ }^{47}$ \\
\hline Micro-ORC & $\begin{array}{l}\text { Downscaling an ORC generator to improve low grade heat, with low power output; achieved isentropic efficiencies for expander and pump were } \\
4.55 \% \text { and } 30 \% \text { in one experiment }{ }^{48}\end{array}$ \\
\hline $\begin{array}{l}\text { Optimizing working } \\
\text { fluid for ORC }\end{array}$ & $\begin{array}{l}\text { N-pentane showed the highest maximized energy efficiency }(53.2 \%) \text { and the lowest minimized levelized cost of electricity }(\$ 0.0863 / \mathrm{kWh}) \text { compared to } \\
\mathrm{R} 245 \mathrm{fa} \text { and n-pentane/R245fa mixture. } 0.05 \text { and } 0.1 \text { molar R245fa are more profitable, although the pure fluids have better thermodynamic } \\
\text { performance than n-pentane/R245fa mixture. R245fa has a high manufacturing cost of } \$ 37 / \mathrm{kg} \text {, and n-pentane has the lowest total capital investment of } \\
\$ 3,184 / \mathrm{kW}^{49} \text { compared to R245fa and n-pentane/R245fa mixture. }\end{array}$ \\
\hline Two-stage ORC & $\begin{array}{l}\text { Uses a series double cascading-evaporating strategy (conventional ORC only has one) } \\
\text { Consists of a high- and low-pressure evaporator, high- and low-pressure pump, induction turbine, generator, condenser, cooling pump, and cooling } \\
\text { tower }{ }^{50}\end{array}$ \\
\hline
\end{tabular}


Table 4-4. Current waste heat recycling technology database.

\begin{tabular}{|c|c|c|c|c|c|c|}
\hline WHR method & Brief description & $\begin{array}{c}\text { Operating } \\
\text { temperature }\end{array}$ & WHR status & Advantages & Disadvantages & WHR potential \\
\hline TMC & $\begin{array}{l}\text { Water vapor from flue } \\
\text { gas is transported } \\
\text { through the } \\
\text { membrane structure } \\
\text { by condensation in } \\
\text { the inner separation } \\
\text { layer, followed by the } \\
\text { intermediate layer, } \\
\text { and then the substrate. } \\
\text { Some condensing } \\
\text { liquid blocks other } \\
\text { gas components. }\end{array}$ & $\begin{array}{l}\text { Highest recovery } \\
\text { rate around } 170^{\circ} \mathrm{F} \\
\text { for metallic } \\
\text { membrane tube }{ }^{51}\end{array}$ & $\begin{array}{l}\text { Developed for } \\
\text { natural gas boiler } \\
\text { flue gas heat and } \\
\text { water recovery, } \\
\text { commercialized } \\
\text { for boiler } \\
\text { optimization }^{52}\end{array}$ & 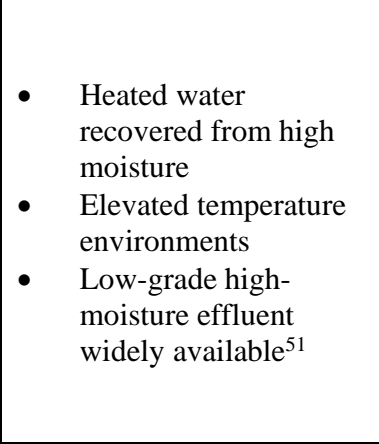 & $\begin{array}{l}\text { Research needed to } \\
\text { develop the porous } \\
\text { membranes working } \\
\text { in the capillary } \\
\text { condensation mode; } \\
\text { also, this process } \\
\text { works best with high } \\
\text { moisture in exhaust } \\
\text { gas }^{51}\end{array}$ & $\begin{array}{l}\text { Potential industry } \\
\text { energy savings of } \\
4,139 \mathrm{TBtu} / \mathrm{year} \text { and } \\
\text { avoided } \mathrm{CO}_{2} \text { emissions } \\
\text { of } 207.1 \text { million } \\
\text { tons/year }\end{array}$ \\
\hline $\begin{array}{c}\text { Rotating } \\
\text { regenerator (heat } \\
\text { wheel) }\end{array}$ & $\begin{array}{l}\text { A wheel made of } \\
\text { heat-conducting } \\
\text { material rotates to } \\
\text { transfer heat between } \\
\text { a stream of waste air } \\
\text { and a stream of fresh } \\
\text { air traveling in } \\
\text { opposite } \\
\text { directions. } \\
\text { ookmark not defrined. }\end{array}$ & $\begin{array}{c}\text { Known current } \\
\text { commercial } \\
\text { systems operate } \\
\text { well above the } \\
\text { low-temperature } \\
\text { range }^{53}\end{array}$ & $\begin{array}{l}\text { Demonstrated for } \\
\text { space heating from } \\
\text { dryer exhausts }{ }^{33}\end{array}$ & $\begin{array}{ll}\text { - } & \text { Low cost } \\
\text { (commercially } \\
\text { available) } \\
\text { - } \\
\text { Designed to facilitate } \\
\text { self-cleaning } \\
\text { - } \\
\text { Recovers latent heat }{ }^{33}\end{array}$ & $\begin{array}{l}\text { - Some fluid mixing is } \\
\text { inevitable, so } \\
\text { caution must be } \\
\text { taken when fluids } \\
\text { cannot be mixed } \\
\text { Heating and cooling } \\
\text { cycles put stress on } \\
\text { heat exchanger, } \\
\text { which causes } \\
\text { cracking }^{33}\end{array}$ & $\begin{array}{l}\text { Effectiveness greater } \\
\text { than } 90 \%^{33}\end{array}$ \\
\hline $\begin{array}{l}\text { Mechanical vapor } \\
\text { recompressor }\end{array}$ & $\begin{array}{l}\text { An open cycle takes } \\
\text { the vapor that leaves } \\
\text { the evaporative } \\
\text { process, compresses } \\
\text { it, and recovers vapor } \\
\text { heat. }^{33}\end{array}$ & - & $\begin{array}{l}\text { Common in } \\
\text { whiskey } \\
\text { distilleries in } \\
\text { Scotland }^{33}\end{array}$ & $\begin{array}{ll}\text { - } & \text { Large potential for } \\
\text { expansion in other } \\
\text { food/industry } \\
\text { subsectors }{ }^{33} \\
\text { - } & \text { Short payback times } \\
\text { - } & \text { Isentropic efficiency } \\
\text { up to } 80 \% \%^{34} \\
\end{array}$ & - & $\begin{array}{l}\text { COP of } 10 \text { common; } \\
\text { short payback periods }\end{array}$ \\
\hline $\begin{array}{l}\text { Plate heat } \\
\text { exchanger }\end{array}$ & $\begin{array}{l}\text { Hot fluid and cold } \\
\text { liquid streams flow } \\
\text { through alternating } \\
\text { channels between } \\
\text { plates, providing a } \\
\text { large surface area for } \\
\text { heat exchange. } .^{33}\end{array}$ & $\begin{array}{c}\text { To prevent } \\
\text { corrosion, water } \\
\text { condensation } \\
\text { should be avoided; } \\
\text { suggested } 248^{\circ} \mathrm{F}- \\
347^{\circ} \mathrm{F} \text { for heat } \\
\text { exchangers }^{54}\end{array}$ & Mature technology & $\begin{array}{l}\text { - Gasketed plate heat } \\
\text { exchanger allows for } \\
\text { easy cleaning } \\
\text { - Can be used for almost } \\
\text { all heat exchanger } \\
\text { duties } \\
\text { - Compact size } \\
\text { - Designed for easy } \\
\text { cleaning }\end{array}$ & - & - \\
\hline
\end{tabular}


Table 4-4. Current waste heat recycling technology database (continued).

\begin{tabular}{|c|c|c|c|c|c|c|}
\hline WHR method & Brief description & $\begin{array}{c}\text { Operating } \\
\text { temperature }\end{array}$ & WHR status & Advantages & Disadvantages & WHR potential \\
\hline $\begin{array}{c}\text { Shell heat } \\
\text { exchanger and } \\
\text { tube heat } \\
\text { exchanger }\end{array}$ & $\begin{array}{c}\text { Heat is transferred } \\
\text { from waste gas stream } \\
\text { to fresh air, using a } \\
\text { large surface area of a } \\
\text { shell and tube } \\
\text { design. }\end{array}$ & $\begin{array}{l}374^{\circ} \mathrm{F} \text { used in a } \\
\text { Thailand study } 55\end{array}$ & $\begin{array}{l}\text { Demonstrated in a } \\
\text { case study in the } \\
\text { Thailand textile } \\
\text { industry }\end{array}$ & $\begin{array}{l}\text { Shell and tube design } \\
\text { increases surface area, } \\
\text { which increases heat } \\
\text { transfer; the internal } \\
\text { rate of return from the } \\
\text { study was } 182 \%^{55}\end{array}$ & - & $\begin{array}{c}\text { Reduced fuel } \\
\text { consumption of } \\
322.72 \mathrm{KJ} / \mathrm{kg}^{55}\end{array}$ \\
\hline $\begin{array}{l}\text { Heat pipe } \\
\text { exchanger }\end{array}$ & $\begin{array}{l}\text { Two streams of } \\
\text { working fluid transfer } \\
\text { heat through a } \\
\text { condensation and } \\
\text { evaporation cycle. } \\
\text { Essentially, a bundle } \\
\text { of heat pipes is } \\
\text { assembled similar to } \\
\text { an air-cooled heat } \\
\text { exchanger. } \\
\end{array}$ & $86^{\circ} \mathrm{F}-392^{\circ} \mathrm{F}^{46}$ & $\begin{array}{c}\text { Some level of } \\
\text { market } \\
\text { introduction since } \\
\text { the early } 1990 \mathrm{~s}^{56}\end{array}$ & $\begin{array}{l}\text { More efficient heat } \\
\text { exchange with low } \\
\text { grade heat than typical } \\
\text { heat exchangers } \\
\text { - } \quad \text { Compact system } \\
\text { - } \\
\text { No moving parts, so it } \\
\text { requires less } \\
\text { maintenance } \\
\text { Needs no input power } \\
\text { for operation }\end{array}$ & $\begin{array}{l}\text { - Higher cost than } \\
\text { typical heat } \\
\text { exchangers }^{46}\end{array}$ & - \\
\hline $\begin{array}{c}\text { Vapor } \\
\text { compression heat } \\
\text { pump }\end{array}$ & $\begin{array}{l}\text { The pump compresses } \\
\text { vapor intake and } \\
\text { transfers the vapor } \\
\text { heat. }^{32}\end{array}$ & $\begin{array}{l}\text { Systems with } \\
\text { condenser } \\
\text { temperature over } \\
302^{\circ} \mathrm{F} \text { in } \\
\text { developement }^{33}\end{array}$ & - & - $\quad \mathrm{COP}$ of $2-6^{32}$ & - & $\begin{array}{c}\text { Significant } \mathrm{CO}_{2} \\
\text { emission savings and } \\
\text { short payback times } \\
\text { possible }\end{array}$ \\
\hline
\end{tabular}


Table 4-5. Research into future waste heat to power technology database.

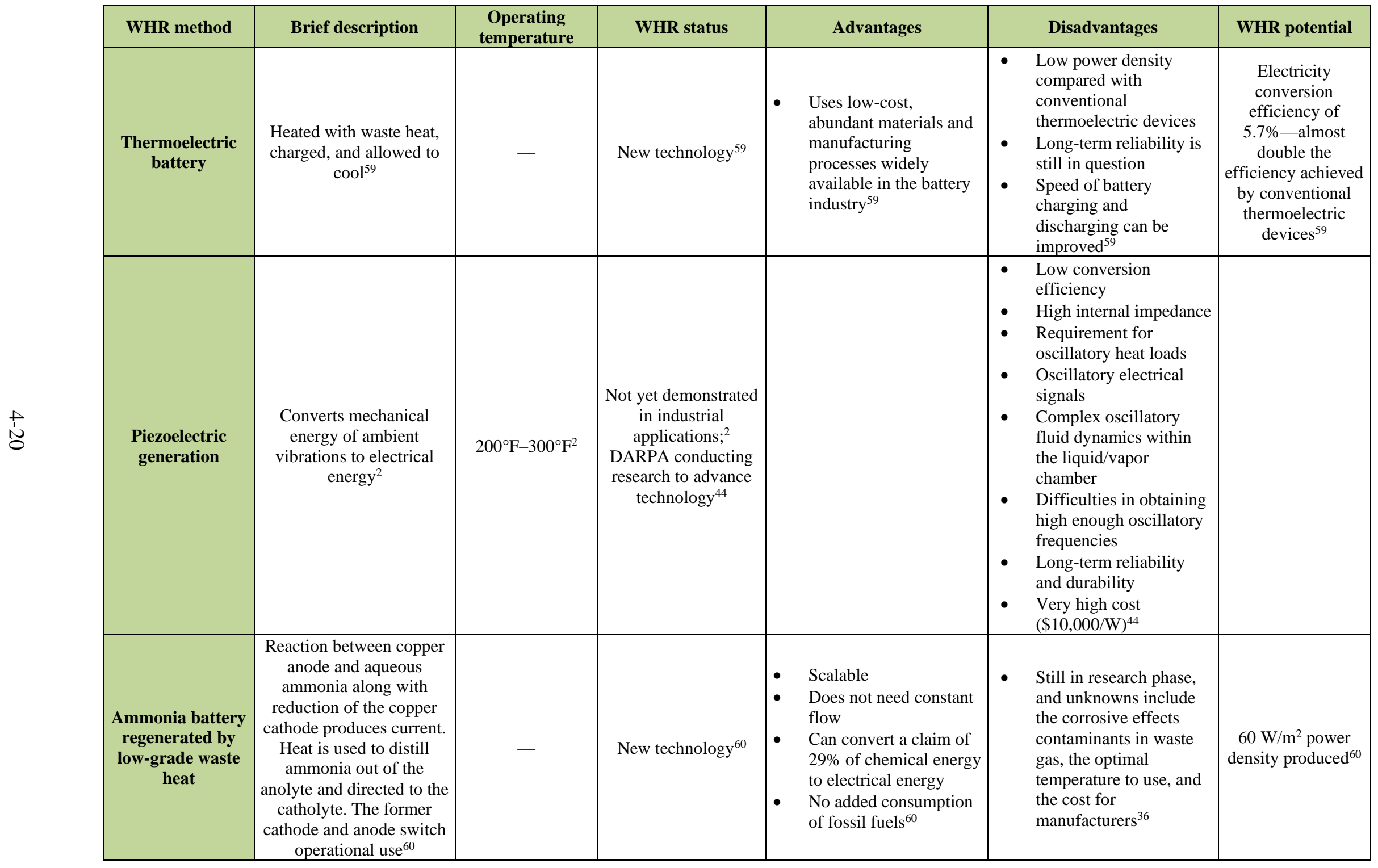




\begin{tabular}{|c|c|c|c|c|c|c|}
\hline WHR method & Brief description & $\begin{array}{l}\text { Operating } \\
\text { temperature }\end{array}$ & WHR status & Advantages & Disadvantages & WHR potential \\
\hline $\begin{array}{c}\text { Thermoacoustic } \\
\text { heat engine }\end{array}$ & $\begin{array}{l}\text { Contains a high- } \\
\text { temperature heat } \\
\text { exchanger, stack, ambient } \\
\text { temperature heat } \\
\text { exchanger, and resonator. } \\
\text { The temperature gradient } \\
\text { between heat exchangers } \\
\text { pushes the compressible } \\
\text { fluid against the stack, } \\
\text { creating a pressure wave } \\
\text { that is transferred to } \\
\text { mechanical energy }\end{array}$ & $\begin{array}{l}\text { Study used } \\
302^{\circ} \mathrm{F}^{61}\end{array}$ & $\begin{array}{l}\text { Emerging } \\
\text { technology }\end{array}$ & 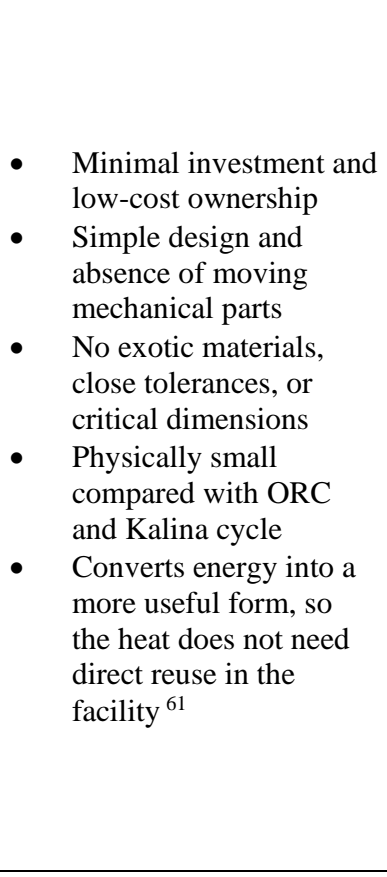 & $\begin{array}{l}\text { Further studies needed } \\
\text { to optimize the heat } \\
\text { exchanger design } \\
\text { Further studies needed } \\
\text { on how thermoacoustic } \\
\text { heat engine technology } \\
\text { responds to large } \\
\text { thermal power input, } \\
\text { mean pressure, and } \\
\text { drive ratio cause } \\
\text { dissipative nonlinear } \\
\text { effects, which could } \\
\text { affect the acoustic } \\
\text { power that the engine } \\
\text { generates } \\
\text { Design improvements } \\
\text { and material } \\
\text { improvement would } \\
\text { increase the thermal } \\
\text { efficiency }{ }^{61} \\
\text { Limited heat exchange } \\
\text { surface and must have } \\
\text { uniform temperature } \\
\text { distribution }{ }^{43} \\
\end{array}$ & $\begin{array}{c}5.38 \% \text { thermal } \\
\text { efficiency and } \\
1,022 \mathrm{~W} \text { of } \\
\text { acoustic power, } \\
\text { maximum of } \\
19 \mathrm{~kW} \text { recovered, }{ }^{60} \\
50 \mathrm{~W} \text { generated, }{ }^{62} \\
3 \mathrm{~kW} \text { and } 41 \% \text { of } \\
\text { Carnot } \\
\text { performance }^{63}\end{array}$ \\
\hline $\begin{array}{l}\text { Vapor absorption } \\
\text { refrigeration } \\
\text { system }\end{array}$ & $\begin{array}{l}\text { Takes the heat from the } \\
\text { steam turbine exhaust and } \\
\text { produces cooled air for } \\
\text { comfort cooling } 64\end{array}$ & $\begin{array}{l}\text { Inlet temperature } \\
\text { of water: } 228^{\circ} \mathrm{F} \text {; } \\
\text { mass flow rate: } \\
3.76 \mathrm{~T} / \mathrm{h} \text {; inlet } \\
\text { pressure of steam } \\
0.6 \mathrm{~kg} / \mathrm{cm}^{2} 64\end{array}$ & $\begin{array}{l}\text { Demonstrated in } \\
\text { Indian sugar plant }{ }^{64}\end{array}$ & $\begin{array}{l}\text { Electrical power } \\
\text { consumption of the } \\
\text { vapor absorption } \\
\text { machine is only around } \\
2 \% \text { of the power used } \\
\text { by a vapor compression } \\
\text { machine }^{64}\end{array}$ & $\begin{array}{l}\text { The heat rejected in the } \\
\text { absorption machine is } \\
\text { about } 60 \% \text { more than in } \\
\text { a vapor compression } \\
\text { machine }^{64}\end{array}$ & $\begin{array}{l}75 \text { tons/year of fuel } \\
\text { savings, total } \\
\text { energy recovery of } \\
45,158 \mathrm{KJ} / \mathrm{kg} \text { more } \\
\text { than vapor } \\
\text { compression } \\
\text { system }^{64} \\
\end{array}$ \\
\hline Goswami cycle & $\begin{array}{c}\text { Combines the Rankine } \\
\text { cycle and vapor } \\
\text { absorption cycle; uses } \\
\text { binary mixture to produce } \\
\text { power and refrigeration at } \\
\text { the same time } \\
\text { 35 }\end{array}$ & - & Research phase ${ }^{35}$ & $\begin{array}{ll}- & \text { Production of power } \\
\text { and cooling in the same } \\
\text { cycle }\end{array}$ & - $\quad$ System complexity & $\begin{array}{c}\text { Goswami cycle } \\
\text { combined with the } \\
\text { Rankine cycle was } \\
\text { found to produce } \\
85 \text { MW max net } \\
\text { work }^{35}\end{array}$ \\
\hline $\begin{array}{c}\text { Trilateral flash/ } \\
\text { VPC } \\
\end{array}$ & $\begin{array}{l}\text { Similar to a binary power } \\
\text { plant, but expansion starts }\end{array}$ & $212^{\circ} \mathrm{F}-482^{\circ} \mathrm{F}^{65}$ & $\begin{array}{l}1 \mathrm{MW} \text { geothermal } \\
\text { test plant facility }\end{array}$ & $\begin{array}{l}\text { Very efficient in } \\
\text { recycling power }\end{array}$ & $\begin{array}{ll}- & \text { Requires high fluid flow } \\
\text { rate }^{87}\end{array}$ & $\begin{array}{l}\text { Potential power } \\
\text { recovery could be }\end{array}$ \\
\hline
\end{tabular}




\begin{tabular}{|c|c|c|c|c|c|c|}
\hline WHR method & Brief description & $\begin{array}{c}\text { Operating } \\
\text { temperature }\end{array}$ & WHR status & Advantages & Disadvantages & WHR potential \\
\hline & $\begin{array}{l}\text { from a saturated liquid } \\
\text { rather than a saturated } \\
\text { vapor. Heat is transferred } \\
\text { from the liquid to the } \\
\text { working fluid with high- } \\
\text { temperature matching } 65\end{array}$ & & operated $^{86}$ & compared with ORC ${ }^{65}$ & & $\begin{array}{c}14 \%-85 \% \text { more } \\
\text { than ORC }\end{array}$ \\
\hline $\begin{array}{l}\text { PCM engine } \\
\text { system }\end{array}$ & $\begin{array}{l}\text { An energy cell converts } \\
\text { heat into mechanical } \\
\text { energy, and then volume } \\
\text { expansion of the material } \\
\text { changing from solid to } \\
\text { liquid produces } \\
\text { electricity }\end{array}$ & $77^{\circ} \mathrm{F}-140^{\circ} \mathrm{F}^{89}$ & $\begin{array}{l}\text { Demonstration } \\
\text { facility in } \\
\text { development }^{89}\end{array}$ & $\begin{array}{l}\text { Capable of very low- } \\
\text { temperature recovery }\end{array}$ & $\begin{array}{l}\text { The heat source must be } \\
\text { in a liquid form and } \\
\text { water must be available } \\
\text { for cooling. The heat } \\
\text { source and cooling } \\
\text { water have equal flow } \\
\text { rates }^{66}\end{array}$ & $\begin{array}{c}\Delta \mathrm{T}=86, \text { efficiency } \\
2 \%-2.5 \% ; \\
\Delta \mathrm{T}=122, \\
\text { efficiency } 3.8 \%- \\
4.4 \% 89\end{array}$ \\
\hline $\begin{array}{l}\text { Stirling engine } \\
\text { system }\end{array}$ & $\begin{array}{l}\text { Isothermal compression, } \\
\text { isochoric heating, } \\
\text { isothermal expansion } \\
\text { during when electricity is } \\
\text { generated, and isochoric } \\
\text { cooling. Two-piston } \\
\text { system; exact mechanics } \\
\text { vary }\end{array}$ & - & $\begin{array}{c}\text { A few systems are } \\
\text { nearing market } \\
\text { entrance }\end{array}$ & $\begin{array}{ll}\text { - } & \text { Minimal O\&M cost } \\
\text { - } & \text { Quiet } \\
\text { - } & \text { High efficiency } \\
& \text { possible }\end{array}$ & - Mechanically complex & $\begin{array}{c}\text { Potential } \\
\text { efficiencies } \\
\text { approaching } \\
\text { Carnot efficiency }\end{array}$ \\
\hline $\begin{array}{l}\text { Thermionic } \\
\text { generator }\end{array}$ & $\begin{array}{l}\text { Electrons move between } \\
\text { two electrodes in a } \\
\text { vacuum space initiated by } \\
\text { thermal energy to produce } \\
\text { current }\end{array}$ & - & & $\begin{array}{ll}\text { - } & \text { Compact device } \\
\text { - } & \text { Quiet operation } \\
\text { - } & \text { Few moving parts, low } \\
\text { maintenance } \\
\text { - } & \text { Operates at high } \\
& \text { temperatures }\end{array}$ & 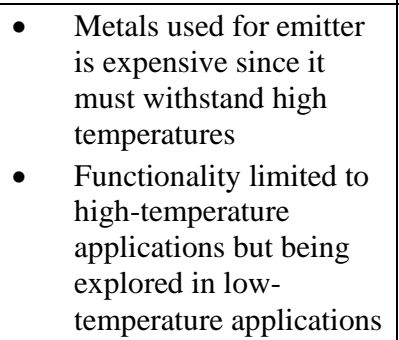 & $\begin{array}{l}\text { Reported } \\
\text { efficiencies in the } \\
\text { range of } 10 \% \text { to } \\
20 \% \\
28,13\end{array}$ \\
\hline
\end{tabular}




\section{ECONOMIC OVERVIEW OF LOW-TEMPERATURE WASTE HEAT TO POWER SYSTEMS}

\subsection{INTRODUCTION}

Short payback periods are necessary for significant market penetration. Figure 5-1 shows how longer payback periods result in less interest in investing in a WHR system: ${ }^{1,104}$ no industrial respondents were interested in waste heat to power systems with a 11 year payback period, whereas all were interested if the payback period was less than 1 year. There is a small chance of purchase and market penetration for 5-10 year payback periods. Short payback periods result in significantly more interest, jumping to a third of respondents at 4 years and nearly half of respondents at 2 years.

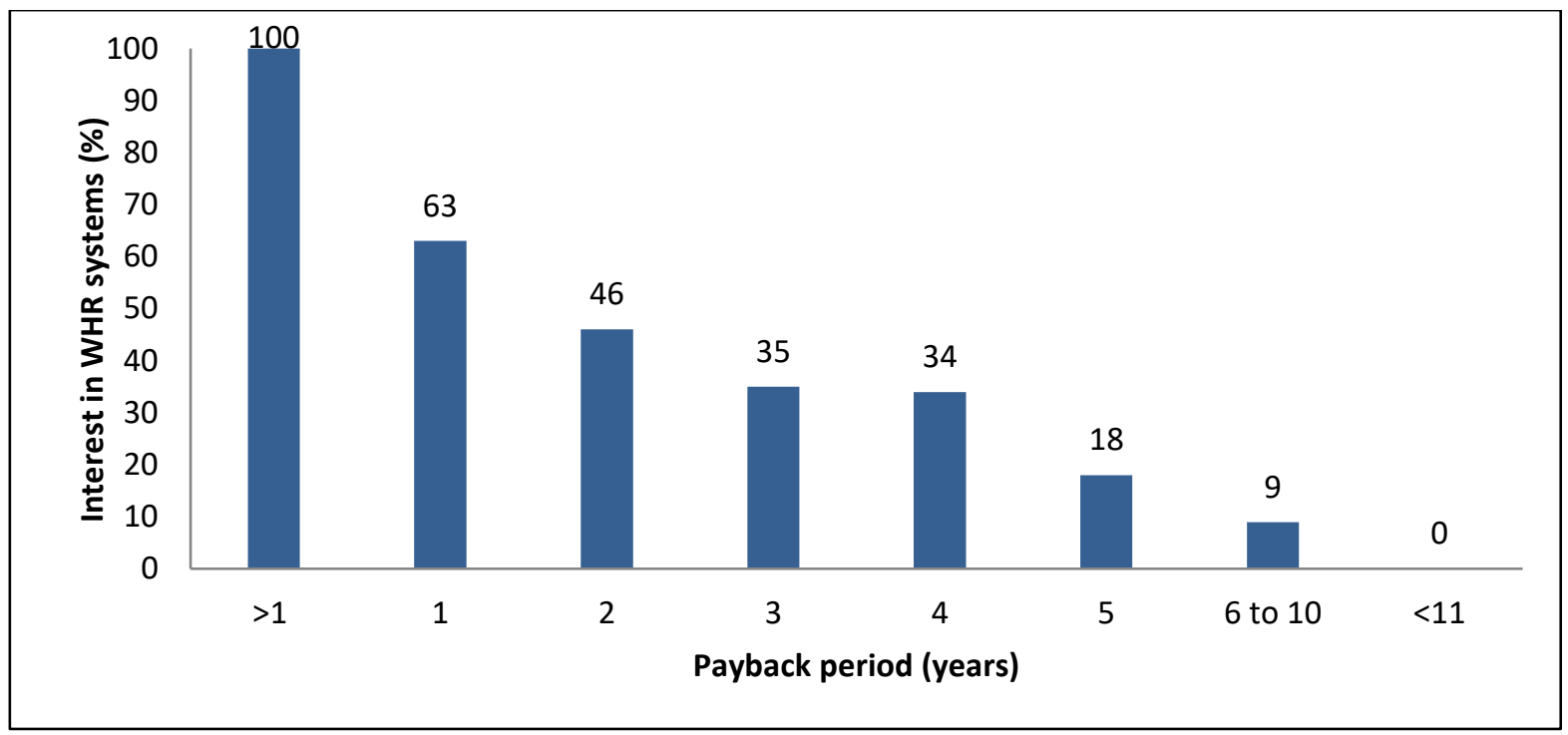

Figure 5-1. Survey results of potential CHP customers and their interest based on time to recuperate investment, adapted from results of a 2003 Primen survey.

Table 5-1 relates industry interest in waste heat to power systems to system and electricity cost via the payback period. For this model, O\&M costs were assumed to be $\$ 0.015 / \mathrm{kWh}$ with 6,500 annual operational hours. Payback periods ranged from 2.4 to 9.5 years (averaging near 6 years) depending on industrial electricity costs (US average is $\$ 0.06 / \mathrm{kWh}-\$ 0.08 / \mathrm{kWh}^{69}$ ) and waste heat system costs $(\$ 1,500 / \mathrm{kW}-\$ 2,500 / \mathrm{kW})$. Although this affords the opportunity for heat recovery systems to diffuse into the market, the system cost needs to decrease to at least the 2 to 5 year payback period for better market infiltration.

The simple payback period method does not consider depreciating value of money or loss of purchasing power, so the need for improved economic performance is required for longer payback periods. To help account for these risks, future cash flow was estimated and converted to present day dollars. The conversion rate used was based off the interest rate of 20 year US Treasury bills with a small increase for risk to $4 \%$ and converted from an annual to a quarterly rate. However, a low simple payback period should not be the only consideration for a long-term investment. The long-term savings over the project's life may make it more viable than a project with a shorter payback period. 
Table 5-1. Model determining payback period of CHP.

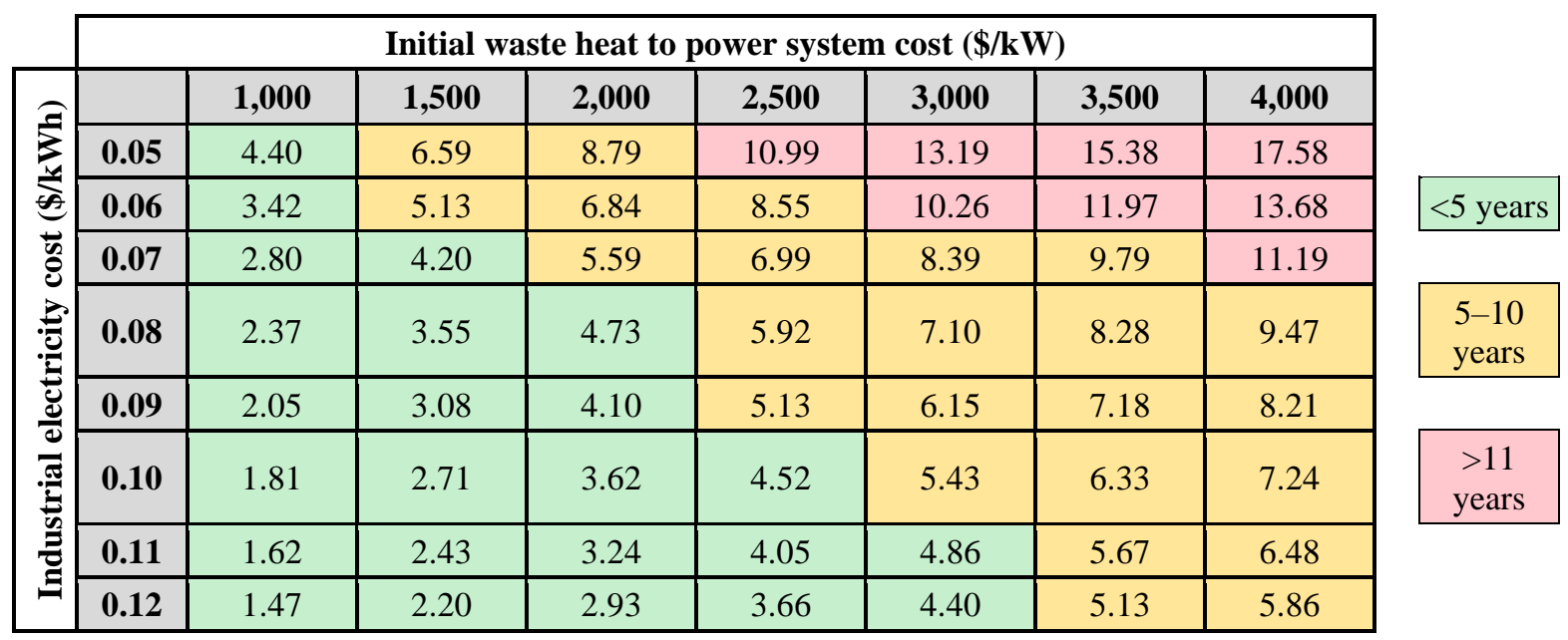

As Figure 5-2 shows, systems with longer payback periods (X-axis in months) may accrue greater overall energy savings than those with shorter payback systems. This baseline data assumes $6,500 \mathrm{hr} / \mathrm{yr}$ operation, installed cost of $\$ 2,000 / \mathrm{kW}, \$ 0.07 / \mathrm{kWh}$ electricity, and $\$ 0.015 / \mathrm{kWh}$ O\&M unless otherwise stipulated. Savings rate is determined by price of electricity, O\&M costs, and hours of operation. While greater risk is involved for such systems, future savings potential can make waste heat to power more attractive if the system has low O\&M or high electricity costs.

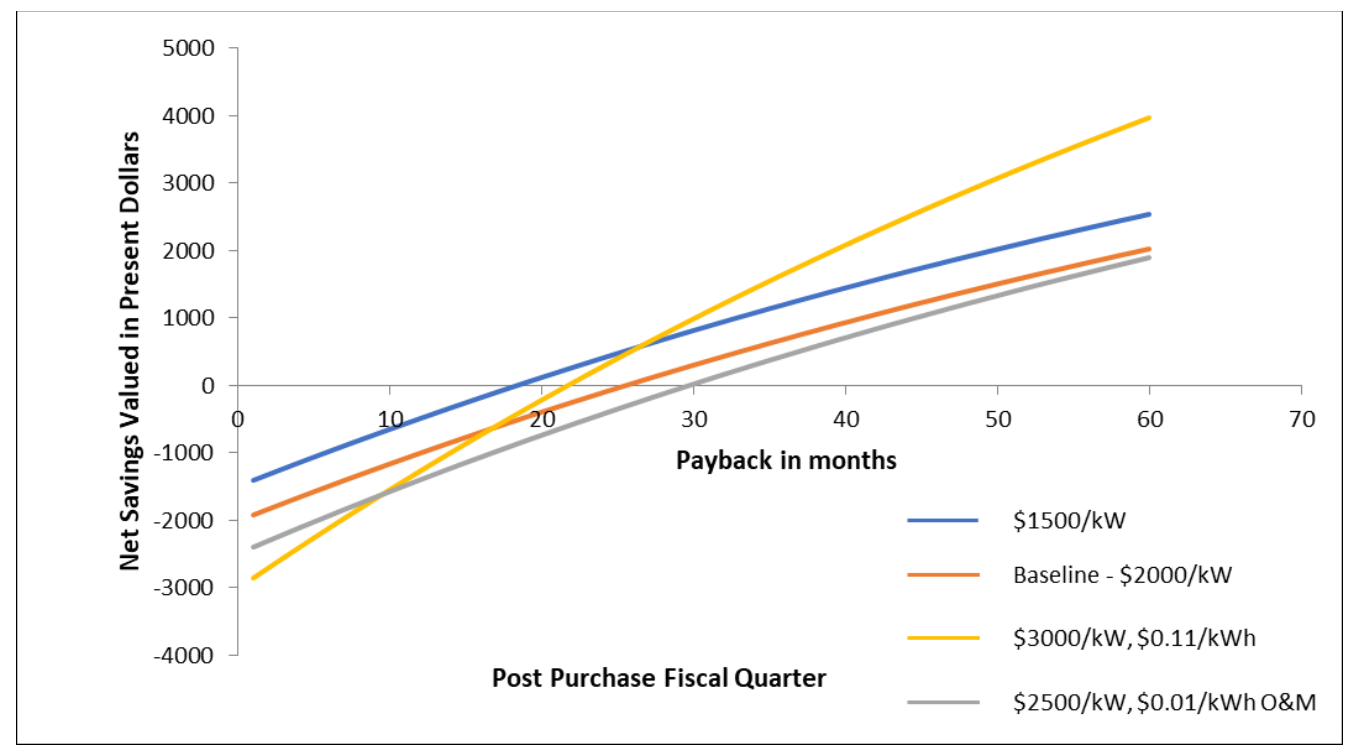

Figure 5-2. Time-dependent present value of waste heat to power system savings.

By far, the most established low-temperature waste heat to power technology is the ORC, ${ }^{1}$ likely because the ORC offers the widest range of electricity outputs and lowest established cost (Figure 5-3). For ORC systems, the largest portion of cost comes from the turbine and heat exchange devices (see Figure 5-4 for more details). ${ }^{105}$ Comparing Figures 5-4, ${ }^{105} 5-5,{ }^{106}$ and 5-6, ${ }^{107}$ general trends in cost intensity can be noted. The single largest cost of these systems is the electricity producing component (i.e., the turbine or engine) followed by heat exchanging devices, boilers, and condensers. There are many opportunities for decreasing cost, including heat exchanger materials with a higher coefficient of thermal conduction; novel 
turbine materials or designs to decrease weight, decrease material cost, and increase lifetime; and manufacturing techniques that minimize material and energy used for fabrication.

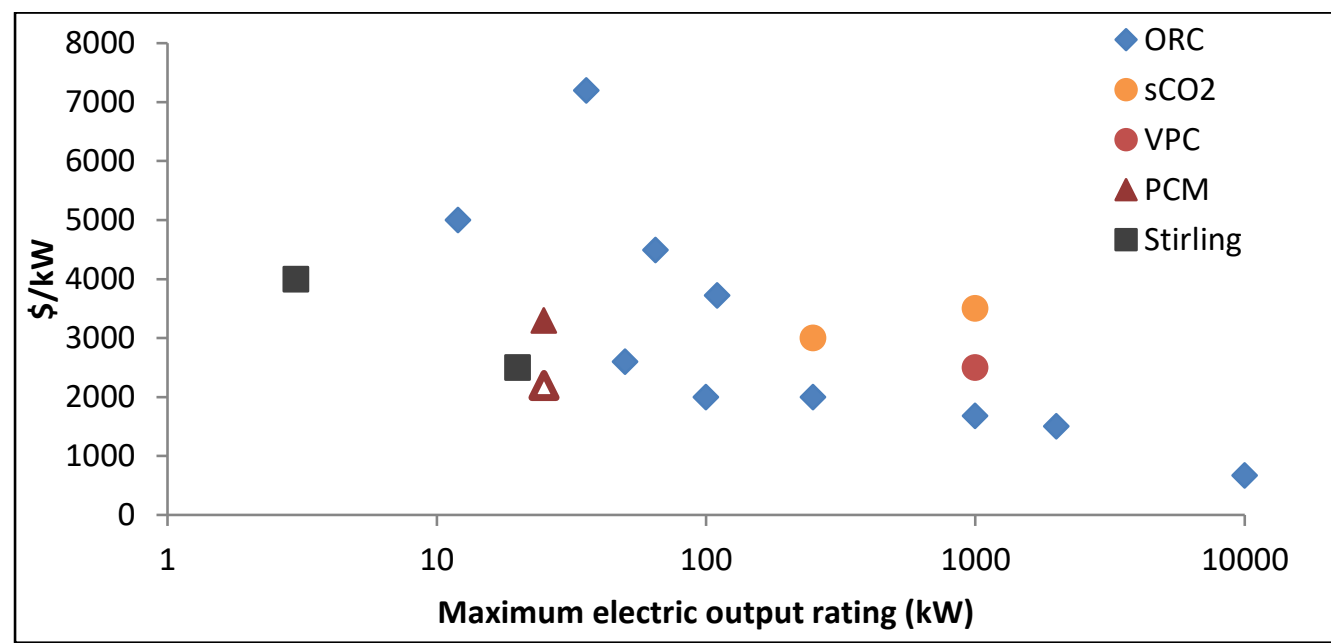

Figure 5-3. Agglomerated cost-size data from industry for comparing different types of waste heat to power systems.

Economies of scale are another important aspect of waste heat to power systems production, both in system size and product demand. As Figure 5-3 shows, maximum electrical output has at least as significant of an effect on the normalized price $(\$ / \mathrm{kW})$ as the type of system. Therefore, it is currently far more economical for facilities with large waste streams to purchase a waste heat to power system despite increased initial capital invested because the payback time decreases with normalized cost. Research efforts are ongoing to make smaller output systems more economical.

Micro-ORC systems are one of the most widely researched systems in the low output heat to power field. These systems share the design simplicity of their larger counterparts. Because of these similarities, a strong knowledge base exists for design parameters and potential issues for micro-ORC, making the extension a logical step for the waste heat to power industry into low-output systems.

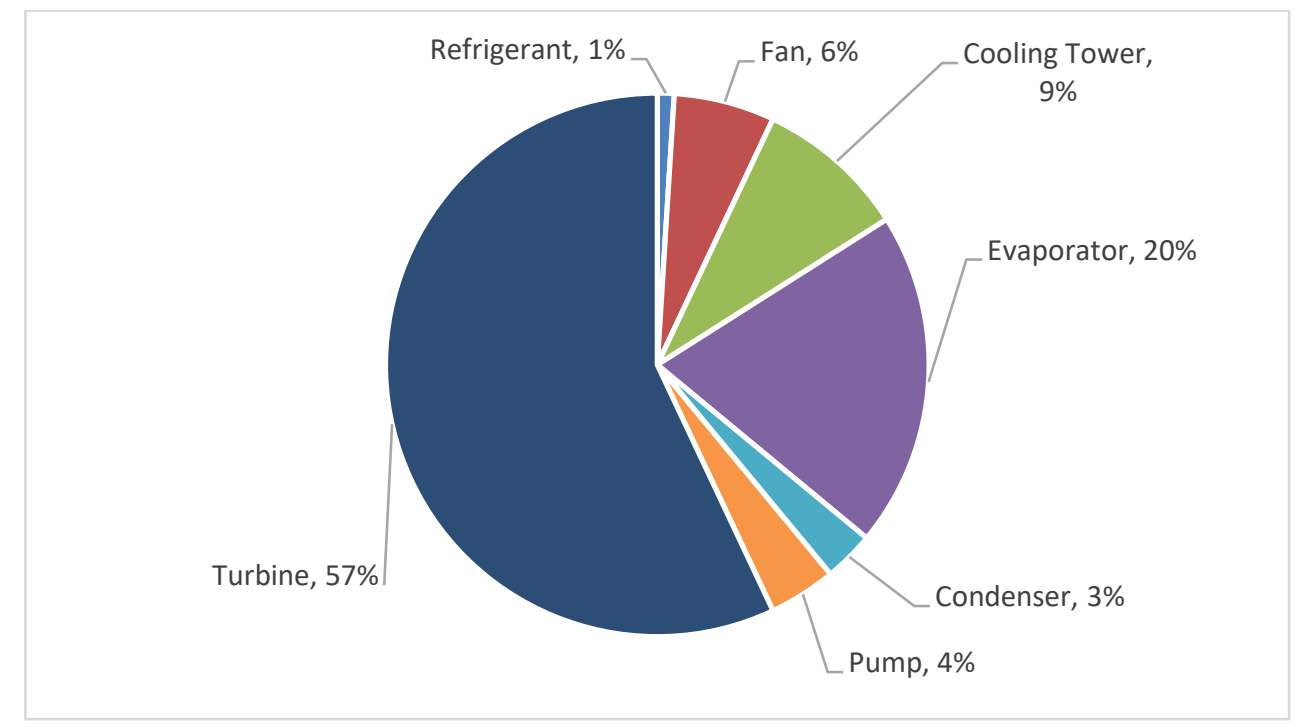

Figure 5-4. Component cost breakdown of an ORC heat recovery system. 
In the same output power region as micro-ORC systems, other system types begin supplanting ORC as the most cost efficient. Figure 5-3 shows that around $10 \mathrm{~kW}$, both PCM and Stirling engines provide greater cost savings than ORC. The PCM engine provides the added advantage of operating at temperatures well below that of most systems, ${ }^{89}$ and Stirling engines are capable of extraordinary efficiencies with some modern equipment reaching $65 \%-70 \%$ of the Carnot cycle. ${ }^{108}$

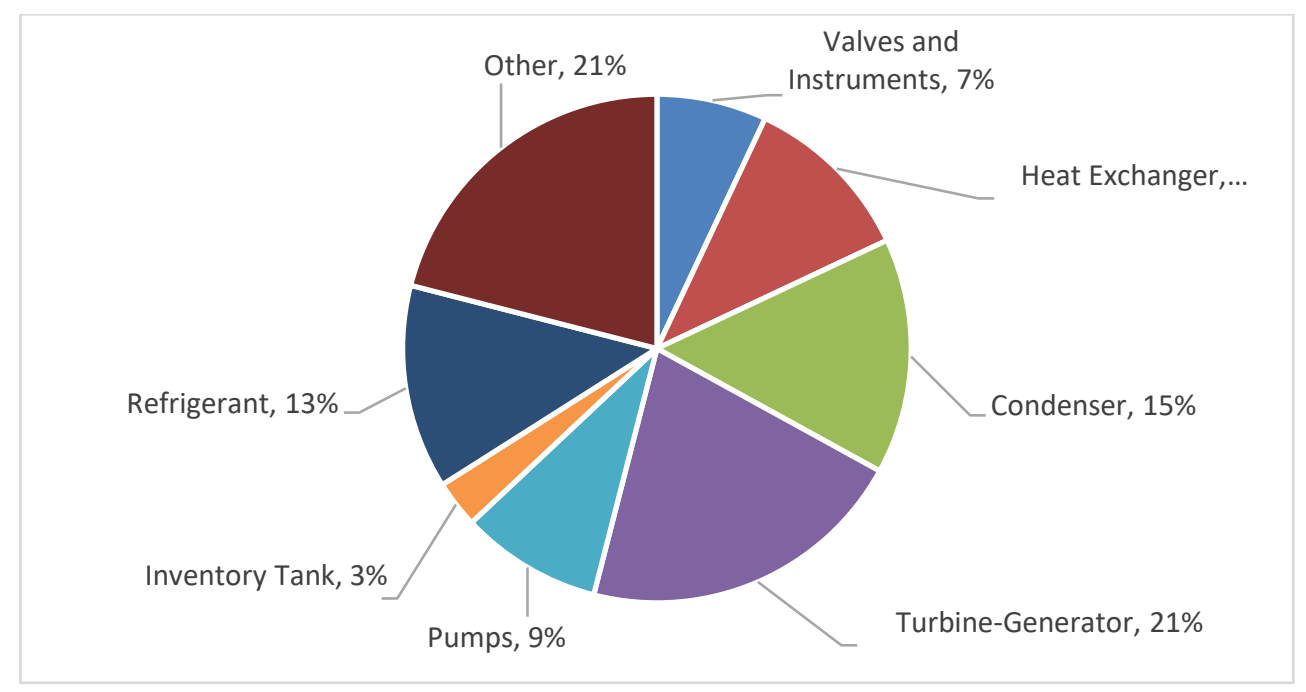

Figure 5-5. Component cost breakdown of a VPC heat recovery system.

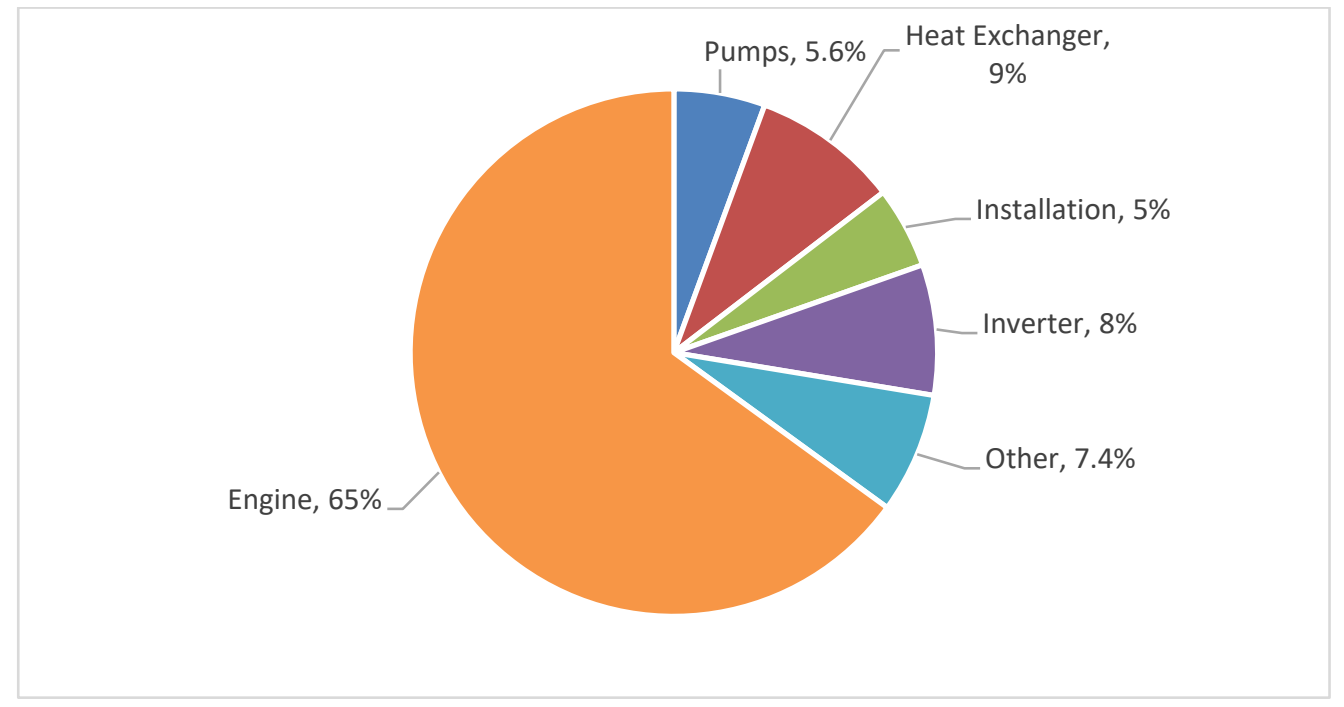

Figure 5-6. Component cost breakdown of a Stirling engine heat recovery system.

At the other end of the output spectrum, Kalina cycle, VPC, ${ }^{85}$ and $\mathrm{sCO}_{2}{ }^{109}$ systems also provide high efficiencies; however, the normalized cost remains similar to the smaller Stirling and PCM systems while ORC normalized cost decreases with increasing output. In addition to the previously discussed economy of scale, economy of scale with respect to product demand is also a factor. The drop in normalized cost around 1 and $10 \mathrm{MW}$ coincides with areas of industry that have seen some of the most significant waste heat to power usage, namely the cement industry, which regularly uses units in this power range. Having been the established waste heat to power system, ORCs would have been produced on a wider, and therefore less expensive, scale than other systems of equivalent size. 
Location of the facility is another important factor in determining the viability of a waste heat to power system. As Table 5-1 and Figure 5-2 show, the price of electricity is a major influence on the economic viability for waste heat to power projects. Although the approximate United States industrial average electricity cost was used to find typical payback, the actual cost paid varies significantly by region. Figure 5-7 shows several regions of higher electricity cost using the spark spread (the difference between electricity and natural gas prices) ${ }^{69}$ For industry in regions with a larger spark spread, waste heat to power systems are more feasible because of the higher savings from avoided electricity costs.

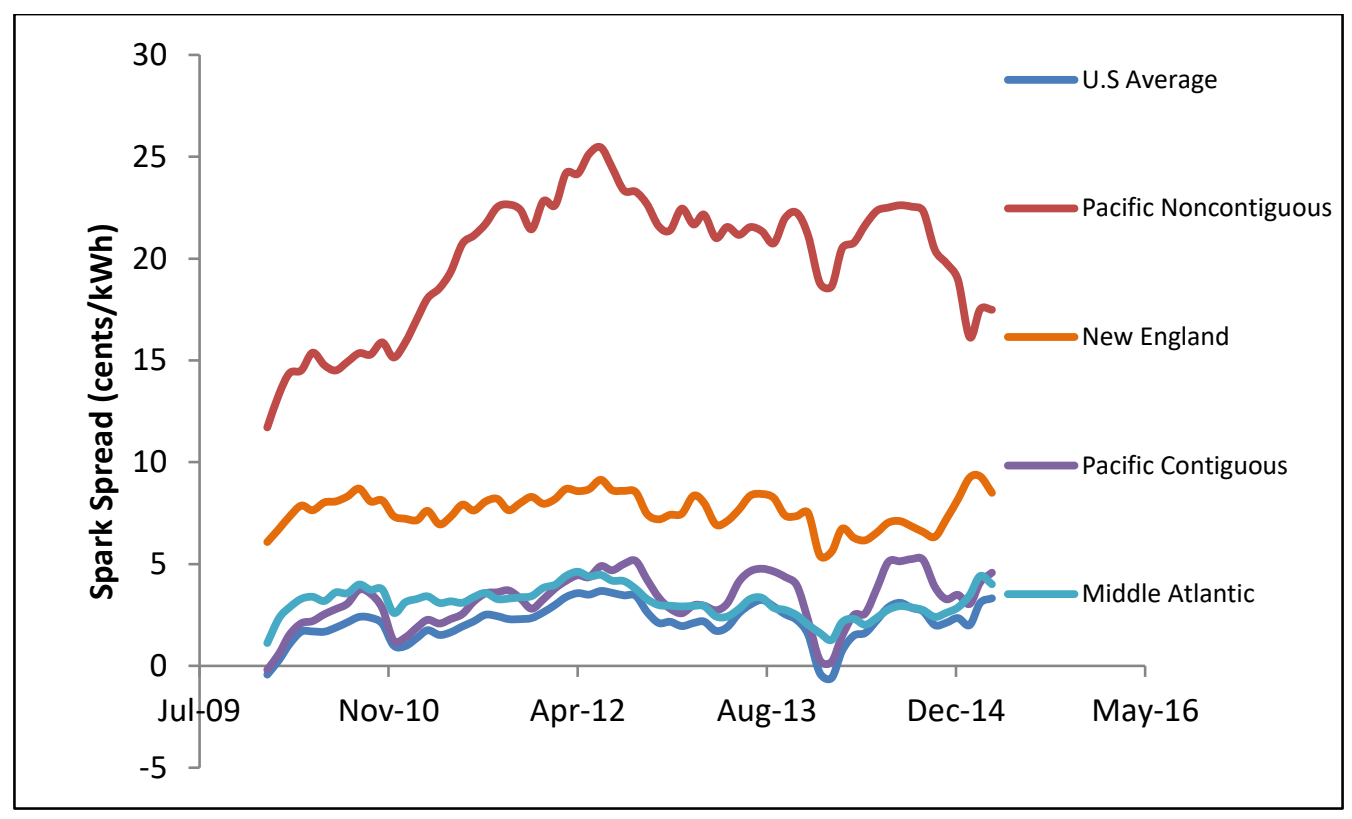

Figure 5-7. Spark spread for selected regions of higher electricity costs.

In addition to energy prices, a few states acknowledge waste heat to power as a renewable equivalent source of energy and provide economic incentive for implementation ${ }^{32}$ (more information can be found in the Database of State Incentives for Renewables and Efficiency). ${ }^{110}$ In California, there is a cap and trade system on $\mathrm{CO}_{2}$ emissions, with recent costs around $\$ 12.50 /$ metric ton of $\mathrm{CO}_{2}$ emissions, ${ }^{111}$ which could decrease the payback period and increase potential savings for WHR systems.

\subsection{CONCLUSIONS}

Because of the large amount of waste heat produced in the low-temperature regime by industry, significant opportunities for WHR exist. The most efficient use of low-temperature waste heat is recycling or reuse for process heating or preheating. The absence of such a process makes waste heat to power systems more economically favorable for many facilities to lower cost and emissions while recovering waste.

Although several system types offer higher efficiency, the ORC most often requires the least initial investment to be paid back, giving it an economic edge. For significant market penetration of other new and emerging technologies, payback period needs to be attractive with cost reduction of turbine/expanders and heat exchangers, along with improvement in efficiencies. Significantly increased interest in purchasing waste heat to power systems should manifest with a system price drop, O\&M decrease, or electricity cost increase that results in shorter payback periods. 


\section{REFERENCES}

1. Elson, A., Tidball, R., and Hampson, A., Waste Heat to Power Market Assessment, ORNL/TM2014/620, ICF International, 2015.

2. BCS, Inc., Waste Heat Recovery: Technology and Opportunities in U.S. Industry, Industrial Technologies Program, 2008.

3. Thekdi, A., Nimbalkar, S., Industrial Crosscutting Research and Development Priorities to Address Waste Energy Minimization and Recovery, ORNL/TM-2014/622, Oak Ridge National Laboratory, 2014.

4. Industrial Heating Equipment Association, Improving Process Heating System Performance: A Sourcebook for Industry, 2nd ed., 2007.

5. Harrell, G., Steam System Survey Guide, ORNL/TM-2001/263, Oak Ridge National Laboratory, 2001.

6. US Environmental Protection Agency (EPA) and Combined Heat and Power (CHP) Partnership report prepared by ICF International, 2015.

7. Capstone Turbines, "Products." [Online] Available at http://www.capstoneturbine.com/products/c30

8. US Energy Information Agency, Manufacturing Energy Consumption Survey (MECS), 2013. [Online] Available at https://www.eia.gov/consumption/manufacturing/data/2010/

9. North American Manufacturing Co., North American Combustion Handbook, 3rd ed., Cleveland, $\mathrm{OH}, 1986$.

10. Jouhara, H., Navid, K., Sulaiman, A., Bertrand, D., Amisha, C., and Savvas, T., "Waste Heat Recovery Technologies and Applications," Thermal Science and Engineering Progress 6, 268-289, 2018.

11. Valdimarsson, P. and Eliasson, L., "Factors Influencing the Economics of the Kalina Power Cycle and Situations of Superior Performance," International Geothermal Conference, 2003.

12. US Department of Energy, "Use Feedwater Economizers for Waste Heat Recovery," Steam Tip Sheet \#3, 2012. [Online] Available at http://energy.gov/eere/amo/downloads/use-feedwatereconomizers-waste-heat-recovery

13. Bickerton, I., and Fox, N. A., "Improving the Efficiency of a Thermionic Energy Converter Using Dual Electric Fields and Electron Beaming”, Frontiers in Mechanical Engineering 3, 14, 2017.

14. Shah , R. K., and Sekulic, D. P., Fundamentals of Heat Exchanger Design, John Wiley \& Sons, NY, 2003.

15. Trinks, W., and Mahoney, M. H., Industrial Furnaces, 4th ed., John Wiley \& Sons, NY, 1967.

16. Industrial Heating Equipment Association. [Online] Available at www.ihea.org.

17. Combustion and Energy Systems, Ltd. [Online] Available at www.combustionandenergy.com

18. Condex Economizer System brochure. [Online] Available at http://www.condexenergy.com/

19. Morales, A. M., "Final Work: Compact Heat Exchangers, Design and Applications," SlideShare, 2013. [Online] Available at www.slideshare.net/adlinilda/compact-heat-exchangers

20. Kays, W. M., Bernard, D., London, A. L., and London, A. L., Compact Heat Exchangers, 3rd ed. Krieger Publishing Company, 1998. 
21. Hesselgreaves, T. E., Compact Heat Exchangers: Selection, Design and Operation, published by Elsevier Science Ltd., London UK, 2001.

22. Alfalaval Compact Heat Exchangers. [Online] Available at https://www.alfalaval.com/increaseefficiency/products/compact-heat-exchangers/

23. Tranter Heat Exchangers. [Online] Available at http://www.tranter.com/about-us

24. Jacobs, R., et al. "Status and Outlook: Industrial Heat Pumps", International Refrigeration and Air Conditioning Conference, Purdue University, USA. 2010.

25. "Industrial Heat Pumps", Emerson Climate Technologies. [Online] Available at https://climate.emerson.com/documents/vilter-heat-pump-white-paper-en-us-5411194.pdf

26. Blatchley C. G., and Stratton H. J., "The Performance of Thermocompressors as Related to Paper Machine Dryer Drainage Systems”, Schutte and Koerting. [Online] Available at www.sk.com/articles/PerformanceThermocompressors.pdf

27. Papar, R., "Absorption Chillers and Refrigeration," Presentation at Southern California Gas Company, 2010.

28. National Aeronautics and Space Administration (NASA), "Portable Compact Thermionic Power Cell”, Category: Power Generation and Storage, Reference No: LAR-TOPS-294, Case No: LAR18860-1. [Online] Available at https://ntts-prod.s3.amazonaws.com/t2p/prod/t2media/tops/pdf/LARTOPS-294.pdf.

29. Kamarul, K., Thye, L., and Khairudin, M., "Review on Thermionic Energy Converters," IEEE Transactions on Electron Devices 63:6, 2231-2241, 2016.

30. US Department of Energy, "Direct Thermal Energy Conversion Materials, Devices, and Systems," Quadrennial Technology Review 2015, Technology Assessment Chapter 6, 2015. [Online] Available at https://www.energy.gov/sites/prod/files/2015/12/f27/QTR2015-6G-Direct-Thermal-EnergyConversion-Materials-Devices-and-Systems.pdf.

31. Nimbalkar, S., and Thekdi, A., Industrial Waste Heat Recovery: Potential Applications Available Technologies and Crosscutting R\&D opportunities (E. a. T. S. Division, Trans.), Oak Ridge National Laboratory and E3M, Inc, 2014.

32. Amarnath, K. R., Waste Heat Recovery in Industrial Facilities: Opportunities for Combined Heat and Power and Industrial Heat Pumps, California Electric Power Research Institute, 2010.

33. Law, R., Harvey, A., and Reay, D., "Opportunity for Low-grade Heat Recovery in the UK Food Process Industry," Sustainable Thermal Energy Management in the Process Industries International Conference, 2011.

34. Arzbaecher, C., Fouche, E., and Parmenter, K., "Industrial Waste Heat Recovery: Benefits and Recent Advancements in Technology and Applications," at the ACEEE Summer Study on Energy Efficiency in Industry, 2007.

35. Kumar, U., and Karimi, M. N., "Low Grade Waste Heat Recovery for Optimized Energy Efficiencies and Enhanced Sustainability in Process Industries: A Comprehensive Review," International Journal of Multidisciplinary Sciences and Engineering, Vol. 5, No. 4, 2014.

36. Nimbalkar, S., Waste Heat Recovery from Industrial Process Heating Equipment, Lawrence Berkley National Laboratory Seminar, 2013.

37. Goel, S., Gerzog, O., Datta, A., Sonde, R. R., Deshpande, K., Fink, J., and Schumacher, T., Market Potential Study for Organic Rankine Cycle Technology in India, Indo-German Energy Forum, 2014. 
38. Haddad, C., Perilhon, C., Danlos, A., Francois, M., and Descombes, G., "Some Efficient Solutions to Recover Low and Medium Waste Heat: Competitiveness of the Thermoacoustic Technology," International Conference on Technologies and Materials for Renewable Energy, 2014.

39. Tchanche, B., Petrissans, M., and Papadakis, G., "Heat resources and organic Rankine cycle machines," Renewable and Sustainable Energy Reviews, Vol. 39, 1185-1199, 2014.

40. Turboden: Organic Rankine Cycle, 2015. [Online] Available at http://www.turboden.eu/en/rankine/rankine-advantages.php

41. International Finance Corporation and Institute for Industrial Productivity, Waste heat recovery for the cement sector: Market and supplier analysis, 2014.

42. Personal Communication with Alphabet Energy. July 2015.

43. Viklund, S., and Johansson, M., "Technologies for utilization of industrial excess heat: Potentials for energy recovery and $\mathrm{CO} 2$ emission reduction," Energy Conversion and Management, Vol. 77, Pp 369-379, 2013.

44. Hendricks, T., Engineering scoping study of thermoelectric generator systems for industrial waste heat recovery, Pacific Northwest Laboratory, Industrial Technologies Program, 2006.

45. Kacludis, A., "Supercritical CO2 Refines Cogeneration," Cogeneration and on-site power production, Power Engineering International, 2013. [Online] Available at https://www.powerengineeringint.com/coal-fired/equipment-coal-fired/supercritical-co2-refinescogeneration/

46. Ammar, Y., Joyce, S., Norman, R., Wang, Y., and Roskilly, A., "Low Grade Thermal Energy Sources and Uses from the Process Industry in the UK," Applied Energy 116, 387-397, 2011.

47. Zhu, Y., Hu, Z., Zhou, Y., Jiang, L., and Yu, L., "Discussion of the Internal Heat Exchanger's Effect on the Organic Rankine Cycle," Applied Thermal Energy 75, 334-343, 2015.

48. Yamada, N., Tominaga, Y., and Yoshida, T., "Demonstration of 10-W micro Organic Rankine Cycle Generator for Low-grade Heat Recovery,” Energy, Elsevier, Vol. 78(C), 806-813, 2014.

49. Le, V., Khieri, A., Feidt, M., and Pelloux-Prayer, S., "Thermodynamic and Economic Optimization of a Waste Heat to Power Plant driven by a Subcritical ORC using Pure or Zeotropic Working Fluid," Energy, Elsevier, Vol. 78(C), 622-638, 2014.

50. Li, T., Wang, Q., Zhu, J., Hu, K., and Fu, W., "Thermodynamic Optimization of Organic Rankine Cycle using Two-stage Evaporation,” Renewable Energy, Vol. 75, 654-664, 2015.

51. Wang, D., Advanced Energy and Water Recovery Technology from Low Grade Waste Heat: Final Technical Report, Prepared for Gas Technology Institute, 2011.

52. Cannon Boiler Works, Cannon Boiler Works Ultramizer Insert. [Online] Available at http://cannonboilerworks.com/wp-content/uploads/Ulramizer_R1.pdf

53. Anderson, B. N., Personal communication with author 2017.

54. Hammond, G. P., and Norman, J. B., "Heat Recovery Opportunities in the UK," Applied Energy 116, 387-397, 2014.

55. Pattanapunt, P., Hussaro, K., Bunnakand, T., and Teekasap, S., "Waste Heat Recovery from Boiler of Large-scale Textile Industry," American Journal of Environmental Science 9:3, 231-239, 2013.

56. Shi, C., Wang, Y., Yang, Y., and Liao, Q., "Heat Transfer Effectiveness of Three-fluid Separated Heat Pipe Exchanger," Science Press and Institute of Engineering Thermophysics, CAS and Springer-Verlag Berlin Heidelberg, 2010. 
57. Industrial Heat Pumps, Frequently Asked Questions. [Online] Available at http://www.industrialheatpumps.nl/en/f_a_q/

58. Bonilla, J. Blanco, J., Lopez, L., and Sala, J., "Technological Recovery Potential of Waste Heat in the Industry of the Basque Country," Applied Thermal Engineering 17:3, 283-288, 1997.

59. Bradley, R., "Batteries that Capture Low Grade Waste Heat: A Third of all Energy Wasted in the U.S. Could Produce Electricity Instead," Scientific American, a Division of Springer Nature America, Inc. Scientific American 311, 6, 53, 2014.

60. Messer, A., Low-grade Waste Heat Regenerated Ammonia Battery, Penn State News, 2014. [Online] Available at https://news.psu.edu/story/336898/2014/12/03/research/low-grade-waste-heatregenerates-ammonia-battery

61. Mumith, J., Makatsorsis, C., and Karayiannis, T. G., "Design of a Thermoacoustic Heat Engine for Low Temperature Waste Heat Recovery in Food Manufacturing," Applied Thermal Engineering 65:1-2, 588-596, 2014.

62. Normah, M. G., Irfan, A. R., Koh, K. S., Manet, A., and Zaki, A. M., "Investigation of a Portable Standing Wave Thermoacoustic Heat Engine,” Procedia Engineering 56, 829-834, 2013.

63. Tijani, T. M., and Spoelstra S., "A Hot Air Driven Thermoacoustic Stirling Engine," Applied Thermal Engineering 61:2, 866-870, 2013.

64. Balaji, K., and Ramkumar, R., "Study of Waste Heat Recovery from Steam Turbine Xhaust for Vapour Absorption System in Sugar Industry," Procedia Engineering, Vol. 38. Pp1352-1356, 2012.

65. Smith, I., Stosie, N., and Aldis, C., "Trilateral Flash Cycle System: A High Efficiency Power Plant for Liquid Resources," Proceedings of the World Geothermal Congress; Firenze, Italy, pp. 21092113, 18-31 May 1995.

66. Johansson, M., and Soderstrom, M., "Electricity generation from low temperature industrial excess heat-an opportunity for the steel industry," Energy Efficiency 7, pp. 203-215, 2014.

67. Abraham, N., Cool Energy Inc. [Online] Available at https://coolenergy.com/resources/informationlibrary/

68. Arvay, P., Muller, M., Ramdeen V., and Cunningham C., "Economic implementation of the organic Rankine cycle in industry," ACEEE Summer Study on Energy Efficiency in Industry, 2011.

69. US Energy Information Administration, Electricity data browser. [Online] Available at http://www.eia.gov/electricity/data/browser/

70. Thekdi, A., Waste Heat Management Options: Industrial Process Heating Systems, 2009.

71. Kalina, A., "New binary geothermal power system,", Proceedings of the International Conference on Geothermal Power Engineering, Sochi, Russia, October 2003. [Online] Available at http://www.geothermal-energy.org/pdf/IGAstandard/Russia/IGW2003/W00024.PDF

72. Sjoding, D., "Overview of Waste Heat Recovery for Power and Heat," at the Waste Heat Recovery for Power and Heat Workshop, Chicago, IL, 2010.

73. Lamonica, M., "A Thermoelectric Generator That Runs on Exhaust Fumes," IEEE Spectrum, 2014. [Online] Available at https://spectrum.ieee.org/energywise/green-tech/conservation/a-thermoelectricgenerator-that-runs-on-exhaust-fumes.

74. "Kalina Cycle Power Systems in Waste Heat Recovery Applications," Global Cement Magazine, August 2012. [Online] Available at http://www.globalcement.com/magazine/articles/721-kalinacycle-power-systems-in-waste-heat-recovery-applications 
75. "Iron and Steel Industry-Waste Heat Recovery," Global Geothermal - Advanced Waste Heat Engineering, 2015. [Online] Available at http://www.globalgeothermal.com/IronSteelIndustry.aspx

76. Whittaker, P., "Corrosion in the Kalina Cycle - An investigation into corrosion problems at the Kalina cycle geothermal power plant in Husavik, Iceland," (Master thesis). A Master's thesis done at RES | the School for Renewable Energy Science in affiliation with University of Iceland \& the University of Akureyri. Akureyri, February 2009. [Online] Available at http://skemman.is/stream/get/1946/7042/17795/1/Peter Whittaker.pdf

77. Giese, G., Personal communication with the author, July 2015.

78. Persichilli, M., Kacludis, A., Zdankiewicz, E., and Held, T., "Supercritical CO2 Power Cycle Developments and Commercialization: Why sCO2 can Displace Steam Echogen Power Systems LLC," at Power-Gen India \& Central Asia, 2012. [Online] Available at http://www.echogen.com/documents/why-sco2-can-displace-steam.pdf

79. Echogen. Applications: Marine. Echogen Power Systems, July 2015. [Online] Available at http://www.echogen.com/our-solution/applications/marine/

80. Universal Industrial Gases, Inc., Material safety data sheet: Gaseous CO2, 2015. [Online] Available at http://www.uigi.com/MSDS_gaseous_CO2.html

81. Persichilli, M., Held, T., Hostler, S., and Zdankiewicz, E., Klapp, D., "Transforming Waste Heat to Power through Development of a $\mathrm{CO}_{2}$-Based Power Cycle," Presented at Electric Power Expo by Echogen Power Systems LLC and American Electric Power, Rosemount, IL U.S., May 2011. [Online] Available at http://www.echogen.com/documents/transforming-waste-heat-to-powerrussia.pdf

82. Giron, M., and Hays, L., Scale Resistant Heat Exchangers for Low Temperature Geothermal Binary Cycle Power Plant: Final Report, Energent Corporation, November 2014.

83. Energent Corporation. Cryogenic Industries. [Online] Available at http://energent.net/projects/wasteheat.html.

84. Hays, L., Personal communication with the author. June 2015.

85. Welch, P., and Boyle, P., New Turbines to Enable Geothermal Power Plants, Energent Corporation, GRC Transactions, Vol. 33, 2009. [Online] Available at http://www.energent.net/documents/Geothermal_Resources_Council_2009_Paper.pdf

86. Geothermal Technologies Peer Review Summary: Variable Phase Turbine Demonstration, 2011.

87. Fischer, J., "Comparison of Trilateral Cycles and Organic Rankine Cycles," Energy, 36, pp. 62086219, 2011.

88. Östlund, B., US Patent WO2009126080 A1: An Energy Cell. April 2008. Exencotech Ab.

89. Östlund, B., Personal communication with the author. June 2015.

90. Hill, J., "Study of Low-Grade Waste Heat Recovery and Energy Transportation Systems in Industrial Applications," Thesis; Alabama University, Department of Mechanical Engineering, University of Alabama, 2011.

91. Kolodny, L., Phononic Devices Raises $\$ 10$ Million to Turn Heat Waste into Energy. TechCrunch Daily. February 23, 2011. [Online] Available at http://techcrunch.com/2011/02/23/phononic-devices10-millio/

92. Cross-campus team receives ARPA-E funding to develop waste heat capture system, Engineering at Illinois, November 2, 2009. [Online] Available at http://engineering.illinois.edu/news/article/200911-02-mechse-professor-receives-arpa-e-funding-develop-novel-waste-heat-capture-system 
93. Johnson, D., Carbon Nanotube-enabled "Power Felt" Could Eventually Power Your Cell Phone, IEEE Spectrum, 2012. [Online] Available at

http://spectrum.ieee.org/nanoclast/semiconductors/nanotechnology/will-carbon-nanotubeenabledpower-felt-be-powering-your-cell-phone-soon

94. Wang, D., Energy and water recovery with transport membrane condenser, Public Interest Energy Research (PIER) Program prepared by Gas Technology Institute, 2013.

95. Gas Technology Institute, Advanced waste heat \& water recovery system demonstration at L.\&N. costume and linen service, 2011. [Online] Available at http://www.ventcondenser.com/documents/White\%20Paper_TMC-

Based\%20HeatWater\%20Recovery\%20for\%20LN.pdf

96. US Department of Energy, Bioelectrochemical Integration of Waste Heat Recovery, Waste-toEnergy Conversion, and Waste-to-Chemical Conversion with Industrial Gas and Chemical Manufacturing Processes, Industrial Technologies Program, 2013. [Online] Available at http://energy.gov/sites/prod/files/2014/06/f17/5750_bioelectrochemical_integration_waste_heat_fact sheet.pdf.

97. Puech, P. and Tishkova, V., "Thermodynamic analysis of a Stirling engine including regenerator dead volume," Renewable Energy 36:2, 872-878, 2011.

98. Karabulut, H., Yücesu, H. S., Çınar, C., and Aksoy, F., "An experimental study on the development of a $\beta$-type Stirling engine for low and moderate temperature heat sources," Applied Energy, Vol. 86, pp. 68-73, 2009.

99. Kongtragool, B., and Wongwises, S., "Investigation on Power Output of the Gamma-configuration Low Temperature Differential Stirling Engines," Renew Energy, Vol. 30:3, pp. 465-476, 2005.

100. Shendage, D. J., Kedare, S. B., and Bapat, S. L., "An Analysis of Beta Type Stirling Engine with Rhombic Drive Mechanism,” Renewable Energy, Vol. 36:1, pp. 289-297, 2011.

101. Scollo, L. S., Valdez, P. E., Santamarina, S. R., Chini, M. R., and Barón, J. H., “Twin Cylinder Alpha Stirling Engine Combined Model and Prototype Redesign,” Hydrogen Energy, Vol. 38:4, pp. 1988-1996, 2013.

102. Lui, H., Nagano, K., Suggiyama, D., Togawa, J., and Nakamura, M., "Honeycomb Filters made from Mesoporous Composite Material for an Open Sorption Thermal Energy Storage System to Store Low-temperature Industrial Waste Heat," International Journal of Heat and Mass Transfer, Vol. 65, pp. 471-480, 2013.

103. Haider, M., and Werner, A., "An overview of state of the art in the fields of sensible, latent and thermochemical thermal energy storage," $e$ \& $i$ Elektrotechnik und Informationstechnik 130:6, pp.153-160, 2013.

104. Primen, Converting Distributed Energy Prospects into Customers, Primen's 2003 Distributed Energy Market Study, Boulder, Colorado, 2003.

105. Mortada, S., Aaraj, Y., Clodic, D., Said, W., and Ksayer, E. B., "Organic Rankine Cycle in Industrial Processes," Proceedings of ECOS 2013, the 26th International Conference on Efficiency, Cost, Optimization, Simulation and Environmental Impact of Energy Systems, July 16-19, 2013.

106. Hays, Lance., "Demonstration of a Variable Turbine Power System for Low Temperature Geothermal Resources, " Energent Corporation, 2012. [Online] Available at https://www.osti.gov/servlets/purl/1136547

107. Cool Energy Inc., Business Overview. Available at http://coolenergy.com/wpcontent/uploads/2014/04/Cool-Energy-Strategic-Introduction-1405201.pdf 
108. Thombare, D. G., and Verma, S. K., "Technological Development in the Stirling Cycle Engines," Renewable and Sustainable Energy Reviews 12:1, pp. 1-38, 2008.

109. Sarkar, J., "Review and Future Trends of Supercritical $\mathrm{CO}_{2}$ Rankine Cycles for Low-grade Heat Conversion," Renewable and Sustainable Energy Reviews 48, pp. 434-451, 2015.

110. NC Clean Energy Technology Center, US Department of Energy. Database of State Incentives for Renewables \& Efficiency. Available at http://www.dsireusa.org/

111. California Cap-and-Trade Program and Quebec Cap-and-Trade System. May 2015 Joint Auction \#3: Summary Results Report.

112. Alimonti, C., and Mohammadzadeh, M., Geothermal Energy Project: A power plant for Húsavík, Iceland, 2019. 10.13140/RG.2.2.23399.80804.

113. Sigma-Aldrich, Materials for Advanced Thermoelectrics, 2015, Retrieved June 29, 2015, [Online] Available at http://www.sigmaaldrich.com/materials-science/metal-and-ceramicscience/thermoelectrics.html.

114. Lines, J., Heat Exchangers in Municipal Wastewater Treatment Plants, Graham Manufacturing Company, Water Engineering \& Management, 9, pp. 28-29, 1991.

\section{Reference Material for Additional Information}

i. $\quad$ Prepared for Sabine Brueske, Ridah Sabouni, Chris Zach, and Howard Andres, US Manufacturing Energy Use and Greenhouse Gas Emissions Analysis, ORNL/TM-2012/504, Energetics, Inc., prepared for Oak Ridge National Laboratory, November 2012.

ii. Thekdi, A., and Bennett, R., Identifying opportunities for waste heat reduction, Energy Matters 2005.

iii. $\quad$ V.V. Viswanthan et al., Opportunity Analysis for Recovering Energy from Industrial Waste Heat and Emissions, Pacific Northwest National Laboratory, April 2006.

iv. M. Kirschen, H. Pfeifer, F. J. Wahlers, H. Mees, "Off-gas Measurements for Mass and Energy Balances of a Stainless Steel EAF," Electric Furnace Proceedings, PR-325-56, Institute for Industrial Furnaces, Aachen, Germany, Association for Iron and Steel Technology 2001.

v. Association for Iron and Steel Technology, US production capability, imports, and inventories, Iron and Steel Technology, July, p. 18, 2014.

vi. $\quad$ Eric Stuart, "Environment and energy impacting U.S. EAF steelmaking sector," presented at Steel Forum, Steel Manufacturers Association, October 18, 2012.

vii. Euan J. Evenston, Howard D. Goodfellow and Michael J. Kempe, "EAF Process Optimization through Off-gas Analysis and Closed-loop Process Control at Deacero, Saltillo, Mexico," Electric Furnace Proceedings, PR-324-005, 2000.

viii. $\quad$ Thekdi Arvind, Process Heating Qualified Specialist Training, 2015.

ix. $\quad$ Andrew Dasinger, Rajul Misra, An Inventory of Industrial Waste Heat and Opportunities for Thermally Activated Technologies. Prepared by United Technologies Research Center. Prepared for Oak Ridge National Lab, 2004.

x. US Environmental Protection Agency, 2001. National Energy Emissions Database

xi. $\quad$ Ozokwelu, D., Porcelli, J., Akinjiola, P., Chemical Bandwidth Study-exergy Analysis: A Powerful Tool for Identifying Process Inefficiencies in the U.S. Chemical Industry. Prepared by JVP International and Psage Research, LLC. Prepared for DOE ITP program, 2006. 
xii. Villar, A., Arribas, J., Parrondo, J., "Waste-to-energy Technologies in Continuous Process Industries," Clean Technology Environmental Policy, 14, 29-39, 2012.

xiii. Beach, R., Bullock, A.M, Heller, K.B., Domanico, J.L., Muth, M.K., O’Connor, A.C., and Spooner, R.B., Lime Production: Industry Profile. Research Triangle Institute Center for Economics Research, prepared for US EPA, 2000. 


\section{APPENDIX A. LOW-TEMPERATURE WASTE HEAT SOURCES FROM MAJOR INDUSTRIAL SECTORS}




\section{APPENDIX A. LOW-TEMPERATURE WASTE HEAT SOURCES FROM MAJOR INDUSTRIAL SECTORS}

\begin{tabular}{|c|c|c|c|c|c|c|c|}
\hline No. & $\begin{array}{l}\text { NAICS } \\
\text { code }\end{array}$ & Application & Application area & $\begin{array}{l}\text { Lower } \\
\text { temp. } \\
\text { range } \\
\left({ }^{\circ} \mathrm{F}\right)\end{array}$ & $\begin{array}{l}\text { Higher } \\
\text { temp. } \\
\text { range } \\
\left({ }^{\circ} \mathbf{F}\right)\end{array}$ & $\begin{array}{l}\text { Waste } \\
\text { heat } \\
\text { form }\end{array}$ & Heat source \\
\hline 1 & 325180 & Calcining & Lime kiln & 1,600 & 1,800 & Gas & Natural gas or oil or other \\
\hline 2 & 325180 & Calcining & Calciner for $\mathrm{NAHCO}_{3}$ & 650 & 650 & Gas & $\begin{array}{c}\text { Natural Gas or oil or } \\
\text { other }\end{array}$ \\
\hline 3 & 325120 & Fluid heating & $\begin{array}{c}\mathrm{H}_{2} \text { generation steam } \\
\text { reformer, heating }\end{array}$ & 1,500 & 1,600 & Gas & $\begin{array}{c}\text { By-product gas or natural } \\
\text { gas }\end{array}$ \\
\hline 4 & 325120 & Fluid heating & $\begin{array}{l}\mathrm{H}_{2} \text { generation steam } \\
\text { reformer, } \mathrm{CO} \\
\text { converter }\end{array}$ & 800 & 800 & Gas & $\begin{array}{l}\text { By-product gas or natural } \\
\text { gas }\end{array}$ \\
\hline 5 & 325130 & Nonmetal heating & $\begin{array}{c}\mathrm{TiO}_{2} \text { heater and } \\
\text { vaporizer }\end{array}$ & 1,120 & 1,120 & Gas & Electricity or natural gas \\
\hline 6 & 325130 & Drying & Pigment dryer & 325 & 325 & Gas & Electricity or natural gas \\
\hline 7 & 325130 & Fluid heating & $\mathrm{O}_{2}$ heater & 1,120 & 1,120 & Gas & Electricity or natural gas \\
\hline 8 & 325130 & Drying & Drying & 250 & 350 & Gas & Electricity or natural gas \\
\hline 9 & 325130 & Calcining & Calciner- $-\mathrm{TiO}_{2}$ & 1,500 & 1,500 & Gas & Electricity or natural gas \\
\hline 10 & 325211 & Drying & Drying & 250 & 350 & Gas & Electricity \\
\hline 11 & 325212 & Fluid heating & Storage heating & 200 & 250 & Gas & Electricity or natural gas \\
\hline 12 & 325220 & Fluid heating & Reactor heating & 450 & 500 & Gas & Electricity or natural gas \\
\hline 13 & 325220 & Nonmetal melting & Melter & 320 & 320 & Gas & Electricity \\
\hline 14 & 325220 & Nonmetal melting & Polymer melter & 450 & 450 & Gas & Electricity \\
\hline 15 & 325220 & Curing and forming & Polymerizer & 540 & 540 & Gas & Electricity \\
\hline 16 & 325412 & Drying & Drying & 200 & 250 & Gas & Electricity \\
\hline 17 & 325110 & Fluid heating & Preheaters & 400 & 500 & Gas & $\begin{array}{c}\text { By-product gas or natural } \\
\text { gas }\end{array}$ \\
\hline 18 & 325110 & Fluid heating & $\begin{array}{c}\text { Steam } \\
\text { heaters/superheaters } \\
\end{array}$ & 750 & 1,300 & Gas & \begin{tabular}{|c|} 
By-product gas or natural \\
gas
\end{tabular} \\
\hline 19 & 325110 & Fluid heating & Reformer (methanol) & 1,500 & 1,500 & Gas & $\begin{array}{c}\text { By-product gas or natural } \\
\text { gas }\end{array}$ \\
\hline 20 & 325110 & Fluid heating & Shift reactor & 500 & 600 & Gas & $\begin{array}{c}\text { By-product gas or natural } \\
\text { gas }\end{array}$ \\
\hline 21 & 325311 & Calcining & Methane preheating & 400 & 450 & Gas & $\begin{array}{c}\text { By-product gas or natural } \\
\text { gas }\end{array}$ \\
\hline 22 & 325311 & Fluid heating & Reformer (methane) & 1,500 & 1,500 & Gas & $\begin{array}{c}\text { By-product gas or natural } \\
\text { gas }\end{array}$ \\
\hline 23 & 324110 & Fluid heating & $\begin{array}{l}\text { Preheating of } \\
\text { crude/feed, etc. }\end{array}$ & 450 & 500 & Gas & $\begin{array}{c}\text { By-product gas or natural } \\
\text { gas }\end{array}$ \\
\hline 24 & 324110 & Fluid heating & $\begin{array}{c}\text { Distillation } \\
\text { (atmospheric and } \\
\text { vacuum) heating }\end{array}$ & 750 & 780 & Gas & $\begin{array}{c}\text { By-product gas or natural } \\
\text { gas }\end{array}$ \\
\hline
\end{tabular}




\begin{tabular}{|c|c|c|c|c|c|c|c|}
\hline No. & $\begin{array}{l}\text { NAICS } \\
\text { code }\end{array}$ & Application & Application area & $\begin{array}{c}\text { Lower } \\
\text { temp. } \\
\text { range } \\
\left({ }^{\circ} \mathrm{F}\right)\end{array}$ & $\begin{array}{l}\text { Higher } \\
\text { temp. } \\
\text { range } \\
\left({ }^{\circ} \mathbf{F}\right)\end{array}$ & $\begin{array}{l}\text { Waste } \\
\text { heat } \\
\text { form }\end{array}$ & Heat source \\
\hline 25 & 324110 & Fluid heating & Coking & 900 & 1,100 & Gas & $\begin{array}{c}\text { By-product gas or natural } \\
\text { gas }\end{array}$ \\
\hline 26 & 324110 & Drying & $\begin{array}{c}\text { Material } \\
\text { drying/processing }\end{array}$ & 700 & 1,000 & Gas & $\begin{array}{c}\text { By-product gas or natural } \\
\text { gas }\end{array}$ \\
\hline 27 & 324110 & Fluid heating & Lube oil processing & 200 & 450 & Steam & Steam \\
\hline 28 & 324110 & Fluid heating & Reforming & 1,100 & 1,400 & Gas & $\begin{array}{c}\text { By-product gas or natural } \\
\text { gas }\end{array}$ \\
\hline 29 & 324110 & Fluid heating & $\begin{array}{l}\text { Recovery boiler } \mathrm{CO} \\
\text { burning }\end{array}$ & 1,000 & 1,600 & Gas & By-product gas \\
\hline 30 & 324121 & Drying & $\begin{array}{c}\text { Material } \\
\text { drying/processing }\end{array}$ & 250 & 400 & Gas & Natural gas or oil \\
\hline 31 & & Curing and forming & $\begin{array}{c}\text { Laminating, casting, } \\
\text { molding }\end{array}$ & 250 & 350 & Gas & Electricity or natural gas \\
\hline 32 & 327211 & Nonmetal heating & $\begin{array}{c}\text { Cullet } \\
\text { drying/preheating }\end{array}$ & 250 & 1,000 & Gas & Natural gas \\
\hline 33 & 327211 & Nonmetal heating & Annealing & 900 & 1,000 & Gas & Electricity or natural gas \\
\hline 34 & 327211 & Heat treating & Tempering & 1,300 & 1,600 & Gas & Electricity or natural gas \\
\hline 35 & 327211 & Nonmetal heating & Laminating/heating & 1,000 & 1,100 & Gas & Electricity or natural gas \\
\hline 36 & 327212 & Curing and forming & Curing ovens & 350 & 650 & Gas & Electricity or natural gas \\
\hline 37 & 327310 & Calcining & Calcining & 500 & 1,000 & Gas & Natural gas or coal \\
\hline 38 & 327120 & Drying & Drying & 250 & 300 & Gas & Electricity or natural gas \\
\hline 39 & 327120 & Curing and forming & Baking-curing & 500 & 1,600 & Gas & Electricity or natural gas \\
\hline 40 & 327999 & Drying & Drying & 250 & 300 & Gas & Natural gas \\
\hline 41 & 327999 & Calcining & Calcining & 500 & 1,000 & Gas & Natural gas \\
\hline 42 & 327993 & Curing and forming & Curing ovens & 350 & 650 & Gas & Electricity or natural gas \\
\hline 43 & 327993 & Nonmetal melting & Melters & 500 & 1,600 & Gas & Electricity or other \\
\hline 44 & 331110 & Metal heating & $\begin{array}{c}\text { Scrap } \\
\text { drying/preheating }\end{array}$ & 350 & 600 & Gas & Natural gas or other \\
\hline 45 & 331110 & Metal heating & Scrap preheating & 1,000 & 1,200 & Gas & Natural gas or other \\
\hline 46 & 331110 & Metal heating & Load preheating & 250 & 600 & Gas & Natural gas or other \\
\hline 47 & 331110 & Metal melting & Direct fired furnaces & 600 & 2,500 & Gas & Direct fired furnaces \\
\hline 48 & 331110 & Drying & Ladle drying & 300 & 400 & Gas & $\begin{array}{c}\text { By-product gas or natural } \\
\text { gas }\end{array}$ \\
\hline 49 & 331110 & Metal melting & $\begin{array}{c}\text { Blast furnace stove air } \\
\text { preheating }\end{array}$ & 200 & 800 & Gas & $\begin{array}{c}\text { By-product gas or natural } \\
\text { gas }\end{array}$ \\
\hline 50 & 331110 & Drying & Ore drying & 300 & 400 & Gas & $\begin{array}{c}\text { By-product gas or natural } \\
\text { gas }\end{array}$ \\
\hline 51 & 331110 & Metal heating & Preheating kilns & 1,200 & 1,600 & Gas & $\begin{array}{c}\text { By-product gas or natural } \\
\text { gas }\end{array}$ \\
\hline 52 & & $\begin{array}{l}\text { Smelting and } \\
\text { agglomeration, etc. }\end{array}$ & Sintering—strand & 500 & 1,500 & Gas & $\begin{array}{c}\text { By-product gas or natural } \\
\text { gas }\end{array}$ \\
\hline 53 & & $\begin{array}{l}\text { Smelting and } \\
\text { agglomeration, etc. }\end{array}$ & Sinter cooling (air) & 250 & 600 & Gas & Other \\
\hline
\end{tabular}




\begin{tabular}{|c|c|c|c|c|c|c|c|}
\hline No. & $\begin{array}{l}\text { NAICS } \\
\text { code }\end{array}$ & Application & Application area & \begin{tabular}{c|} 
Lower \\
temp. \\
range \\
$\left({ }^{\circ} \mathbf{F}\right)$
\end{tabular} & $\begin{array}{l}\text { Higher } \\
\text { temp. } \\
\text { range } \\
\left({ }^{\circ} \mathbf{F}\right)\end{array}$ & $\begin{array}{l}\text { Waste } \\
\text { heat } \\
\text { form }\end{array}$ & Heat source \\
\hline 54 & 331511 & Drying & Mold drying & 500 & 600 & Gas & Natural gas or other \\
\hline 55 & 331511 & Metal heating & Core baking & 400 & 450 & Gas & Natural gas or other \\
\hline 56 & 331511 & Metal heating & Sand reclamation & 800 & 1,200 & Gas & Natural gas or other \\
\hline 57 & 331511 & Heat treating & $\begin{array}{c}\text { Heat treating } \\
\text { (tempering) }\end{array}$ & 300 & 900 & Gas & Electricity or natural gas \\
\hline 58 & 331511 & Heat treating & $\begin{array}{c}\text { Heat treating } \\
\text { (hardening, heating for } \\
\text { forging }\end{array}$ & 300 & 1,600 & Gas & Electricity or natural gas \\
\hline 59 & 331313 & Calcining & Calcining & 400 & 800 & Gas & $\begin{array}{c}\text { By-product gas or natural } \\
\text { gas }\end{array}$ \\
\hline 60 & 331313 & Metal heating & Anode baking & 500 & 2,000 & Gas & Natural gas or oil \\
\hline 61 & 331314 & Metal heating & $\begin{array}{c}\text { Scrap } \\
\text { drying/preheating }\end{array}$ & 350 & 600 & Gas & Natural gas or other \\
\hline 62 & 331314 & Metal heating & Melting furnace & 1,250 & 1,350 & Gas & Electricity or natural gas \\
\hline 63 & 331314 & Heat treating & $\begin{array}{l}\text { Solution treatment } \\
\text { furnaces }\end{array}$ & 350 & 400 & Gas & Electricity or natural gas \\
\hline 64 & 331314 & Metal heating & $\begin{array}{c}\text { Direct fired } \\
\text { homogenizing } \\
\text { furnaces }\end{array}$ & 350 & 1,000 & Gas & Natural gas \\
\hline 65 & & Metal melting & Sweating furnace & 1,000 & 1,000 & Gas & $\begin{array}{c}\text { By-product gas or natural } \\
\text { gas }\end{array}$ \\
\hline 66 & & Metal melting & Melting furnace & 1,000 & 1,000 & Gas & Natural gas \\
\hline 67 & & Metal heating & Mold preheating & 250 & 400 & Gas & Electricity or natural gas \\
\hline 68 & & Metal melting & Distillation furnace & 2,400 & 2,400 & Gas & Natural gas \\
\hline 69 & & Metal heating & $\begin{array}{c}\text { Scrap } \\
\text { drying/preheating }\end{array}$ & 350 & 600 & Gas & Natural gas or other \\
\hline 70 & & Metal melting & Sweating furnace & 1,000 & 1,100 & Gas & $\begin{array}{c}\text { By-product gas or natural } \\
\text { gas }\end{array}$ \\
\hline 71 & & Metal melting & $\begin{array}{l}\text { Melting/refining } \\
\text { furnaces }\end{array}$ & 2,000 & 2,400 & Gas & Natural gas or other \\
\hline 72 & 331315 & Metal melting & $\begin{array}{l}\text { Melting/refining } \\
\text { furnace }\end{array}$ & 1,200 & 1,400 & Gas & Electricity or natural gas \\
\hline 73 & 331315 & Metal heating & $\begin{array}{l}\text { Slab/billet/ingot } \\
\text { preheating }\end{array}$ & 1,000 & 1,000 & Gas & Natural gas \\
\hline 74 & 331315 & Heat treating & Annealing & 400 & 1,000 & Gas & Electricity or natural gas \\
\hline 75 & 331524 & Metal heating & $\begin{array}{c}\text { Scrap } \\
\text { drying/preheating }\end{array}$ & 350 & 600 & Gas & Natural gas or other \\
\hline 76 & 331524 & Metal melting & Melting furnace & 1,250 & 1,350 & Gas & Electricity or natural gas \\
\hline 77 & 331524 & Heat treating & $\begin{array}{l}\text { Solution treatment } \\
\text { furnace }\end{array}$ & 350 & 400 & Gas & Natural gas \\
\hline 78 & 331524 & Metal heating & $\begin{array}{c}\text { Direct fired } \\
\text { homogenizing furnace }\end{array}$ & 350 & 1,000 & Gas & Natural gas \\
\hline 79 & 332811 & Heat treating & $\begin{array}{l}\text { Variety of atmosphere } \\
\text { heat treating processes }\end{array}$ & 400 & 1,600 & Gas & Electricity or natural gas \\
\hline
\end{tabular}




\begin{tabular}{|c|c|c|c|c|c|c|c|}
\hline No. & $\begin{array}{l}\text { NAICS } \\
\text { code }\end{array}$ & Application & Application area & $\begin{array}{c}\text { Lower } \\
\text { temp. } \\
\text { range } \\
\left({ }^{\circ} \mathbf{F}\right)\end{array}$ & $\begin{array}{l}\text { Higher } \\
\text { temp. } \\
\text { range } \\
\left({ }^{\circ} \mathbf{F}\right)\end{array}$ & $\begin{array}{l}\text { Waste } \\
\text { heat } \\
\text { form }\end{array}$ & Heat source \\
\hline 80 & 332431 & Fluid heating & $\begin{array}{l}\text { Metal cleansing and } \\
\text { rinsing }\end{array}$ & 200 & 500 & Gas & Steam or natural gas \\
\hline 81 & 332431 & Drying & Drying ovens & 200 & 400 & Gas & Electricity or natural gas \\
\hline 82 & 332431 & Fluid heating & Thermal oxidizers & 400 & 1,400 & Gas & Natural gas or other \\
\hline 83 & 332312 & Fluid heating & $\begin{array}{l}\text { Metal cleansing and } \\
\text { rinsing }\end{array}$ & 200 & 500 & Gas & Steam or natural gas \\
\hline 84 & 332312 & Drying & Drying ovens & 200 & 400 & Gas & Electricity or natural gas \\
\hline 85 & 332312 & Fluid heating & Thermal oxidizers & 400 & 1,400 & Gas & Natural gas or other \\
\hline 86 & 332111 & Metal heating & $\begin{array}{l}\text { Preheating prior to } \\
\text { induction heating }\end{array}$ & 600 & 1,400 & Gas & Natural gas or other \\
\hline 87 & 332111 & Heat treating & Annealing & 400 & 700 & Gas & Electricity or natural gas \\
\hline 88 & 332111 & Heat treating & Heat treatment & 400 & 700 & Gas & Electricity or natural gas \\
\hline 89 & 332216 & Curing and forming & Paint drying & 200 & 350 & Gas & Electricity or natural gas \\
\hline 90 & 332216 & Heat treating & Heat treatment & 1,000 & 1,600 & Gas & Electricity or natural gas \\
\hline 91 & 311340 & Drying & $\begin{array}{l}\text { Beet sugar production } \\
\text { charcoal regenerator }\end{array}$ & 200 & 200 & Gas & Electricity or natural gas \\
\hline 92 & 311211 & Drying & $\begin{array}{l}\text { Drying for feed and } \\
\text { product }\end{array}$ & 300 & 450 & Gas & Electricity or natural gas \\
\hline 93 & 311340 & Nonmetal heating & Cane sugar refining & 900 & 900 & Gas & Electricity or natural gas \\
\hline 94 & 311340 & Calcining & \begin{tabular}{|c} 
Beet sugar production \\
lime kiln
\end{tabular} & 600 & 600 & Gas & Electricity or natural gas \\
\hline 95 & 313210 & Nonmetal heating & Singeing & 400 & 400 & Gas & Electricity or natural gas \\
\hline 96 & 321920 & Drying & $\begin{array}{c}\text { Fiberboard } \\
\text { stabilization/drying }\end{array}$ & 350 & 350 & Gas & Electricity or natural gas \\
\hline 97 & 322110 & Calcining & Lime kiln & 1,200 & 1,200 & Gas & Natural gas or oil or other \\
\hline 98 & 322121 & Calcining & Lime kiln & 1,200 & 1,200 & Gas & Natural gas or oil or other \\
\hline 99 & 323117 & Fluid heating & Fluid Heating & 1,400 & 1,600 & Gas & Natural gas or other \\
\hline 100 & 325120 & Fluid heating & $\begin{array}{l}\text { Compressed industrial } \\
\text { gas manufacturing }\end{array}$ & 200 & 350 & Gas & Electricity or natural gas \\
\hline
\end{tabular}

Source: Arvind Thekdi (E3M Inc.) 
APPENDIX B. LOW-TEMPERATURE WASTE HEAT ESTIMATE BASED ON MECS DATA 


\section{APPENDIX B. LOW-TEMPERATURE WASTE HEAT ESTIMATE BASED ON MECS DATA}

\begin{tabular}{|c|c|c|c|c|c|c|c|c|c|}
\hline $\begin{array}{l}\text { NAICS } \\
\text { code }(a)\end{array}$ & End use & $\begin{array}{c}\text { Residual } \\
\text { fuel oil }\end{array}$ & \begin{tabular}{|c|} 
Distillate \\
fuel oil \\
and \\
diesel \\
fuel(c)
\end{tabular} & $\begin{array}{c}\text { Natural } \\
\operatorname{gas}(d)\end{array}$ & $\begin{array}{l}\text { LPG and } \\
\text { NGL(e) }\end{array}$ & $\begin{array}{c}\text { Coal } \\
\text { (excluding } \\
\text { coke and } \\
\text { breeze) }\end{array}$ & $\begin{array}{c}\text { Other } \\
\text { (f) }\end{array}$ & $\begin{array}{c}\text { Percent } \\
\text { waste } \\
\text { heat }\end{array}$ & $\begin{array}{l}\text { Waste heat } \\
\text { TBtu/year } \\
\text { Low temp }\end{array}$ \\
\hline \multirow[t]{8}{*}{311} & Food & & & & & & & & \\
\hline & TOTAL FUEL CONSUMPTION & 12 & 22 & 579 & 6 & 182 & 101 & $17.5 \%$ & 17.7 \\
\hline & Indirect Uses-Boiler Fuel & 10 & 3 & 334 & 2 & 162 & - & & \\
\hline & Conventional Boiler Use & 5 & 1 & 164 & $*$ & 25 & - & $17.5 \%$ & 34.1 \\
\hline & CHP and/or Cogeneration Process & 4 & 2 & 170 & 1 & 137 & - & $10 \%$ & 31.4 \\
\hline & Direct Uses-Total Process & 1 & 7 & 189 & 2 & 18 & - & & \\
\hline & Process Heating & 1 & $\mathrm{Q}$ & 175 & 1 & 17 & - & $30 \%$ & 58.2 \\
\hline & End Use Not Reported & 1 & 2 & 7 & $*$ & 1 & 101 & & \\
\hline \multirow[t]{8}{*}{3112} & Grain and Oilseed Milling & & & & & & & & \\
\hline & TOTAL FUEL CONSUMPTION & $*$ & 1 & 121 & $*$ & 126 & 45 & $17.5 \%$ & 7.9 \\
\hline & Indirect Uses-Boiler Fuel & $*$ & $*$ & 70 & $*$ & 115 & - & & \\
\hline & Conventional Boiler Use & $*$ & $*$ & 38 & $*$ & 17 & 一 & $17.5 \%$ & 9.6 \\
\hline & CHP and/or Cogeneration Process & $*$ & $*$ & 32 & 0 & 99 & - & $17.5 \%$ & 22.9 \\
\hline & Direct Uses-Total Process & $*$ & $*$ & 47 & $*$ & 9 & - & & \\
\hline & Process Heating & $*$ & 0 & 44 & $*$ & 8 & - & $20 \%$ & 10.4 \\
\hline & End Use Not Reported & 0 & $*$ & 1 & $*$ & 1 & 45 & & \\
\hline \multirow[t]{8}{*}{311221} & Wet Corn Milling & & & & & & & & \\
\hline & TOTAL FUEL CONSUMPTION & $*$ & $*$ & 53 & $*$ & 110 & 25 & $17.5 \%$ & 4.4 \\
\hline & Indirect Uses-Boiler Fuel & 0 & $*$ & 23 & 0 & 102 & - & & \\
\hline & Conventional Boiler Use & 0 & 0 & 15 & 0 & 13 & - & $17.5 \%$ & 4.9 \\
\hline & CHP and/or Cogeneration Process & 0 & $*$ & 8 & 0 & 90 & - & $17.5 \%$ & 17.2 \\
\hline & Direct Uses-Total Process & $*$ & $*$ & 29 & $*$ & 8 & - & & \\
\hline & Process Heating & $*$ & 0 & 29 & $*$ & 8 & 一 & $20 \%$ & 7.4 \\
\hline & End Use Not Reported & 0 & 0 & 0 & $*$ & 0 & 25 & & \\
\hline \multirow[t]{8}{*}{31131} & Sugar & & & & & & & & \\
\hline & TOTAL FUEL CONSUMPTION & 1 & 1 & 15 & $*$ & 49 & 37 & $17.5 \%$ & 6.5 \\
\hline & Indirect Uses-Boiler Fuel & 1 & $*$ & 12 & $*$ & 40 & - & & \\
\hline & Conventional Boiler Use & $*$ & 0 & 3 & $*$ & 3 & - & $17.5 \%$ & 1.1 \\
\hline & $\mathrm{CHP}$ and/or Cogeneration Process & 1 & $*$ & 9 & $*$ & 37 & - & $17.5 \%$ & 8.2 \\
\hline & Direct Uses-Total Process & 0 & $*$ & 3 & $*$ & 8 & - & & \\
\hline & Process Heating & 0 & 0 & 3 & 0 & 8 & - & $20 \%$ & 2.2 \\
\hline & End Use Not Reported & 0 & $*$ & 0 & $*$ & 0 & 37 & & \\
\hline \multirow[t]{8}{*}{3114} & $\begin{array}{l}\text { Fruit and Vegetable Preserving and } \\
\text { Specialty Foods }\end{array}$ & & & & & & & & \\
\hline & TOTAL FUEL CONSUMPTION & 1 & $\mathrm{Q}$ & 100 & 1 & 2 & 4 & $17.5 \%$ & 0.7 \\
\hline & Indirect Uses-Boiler Fuel & 1 & $*$ & 66 & $*$ & 2 & - & & \\
\hline & Conventional Boiler Use & 1 & $*$ & 34 & $*$ & 1 & - & $17.5 \%$ & 6.3 \\
\hline & CHP and/or Cogeneration Process & $*$ & $*$ & 32 & $*$ & 1 & - & $17.5 \%$ & 5.8 \\
\hline & Direct Uses-Total Process & $*$ & $\mathrm{Q}$ & 23 & $*$ & 0 & - & & \\
\hline & Process Heating & $*$ & $\mathrm{Q}$ & 22 & $*$ & 0 & - & $20 \%$ & 4.4 \\
\hline & End Use Not Reported & 0 & $*$ & 1 & $*$ & 0 & 4 & & \\
\hline \multirow[t]{4}{*}{3115} & Dairy Products & & & & & & & & \\
\hline & TOTAL FUEL CONSUMPTION & 2 & 2 & 66 & 1 & $*$ & 2 & $17.5 \%$ & 0.4 \\
\hline & Indirect Uses-Boiler Fuel & 1 & 1 & 41 & $*$ & $*$ & - & & \\
\hline & Conventional Boiler Use & 1 & $*$ & 17 & $*$ & $*$ & - & $17.5 \%$ & 3.2 \\
\hline
\end{tabular}




\begin{tabular}{|c|c|c|c|c|c|c|c|c|c|}
\hline $\begin{array}{l}\text { NAICS } \\
\text { code(a) }\end{array}$ & End use & $\begin{array}{c}\text { Residual } \\
\text { fuel oil }\end{array}$ & $\begin{array}{c}\text { Distillate } \\
\text { fuel oil } \\
\text { and } \\
\text { diesel } \\
\text { fuel(c) }\end{array}$ & $\begin{array}{c}\text { Natural } \\
\text { gas(d) }\end{array}$ & $\begin{array}{c}\text { LPG and } \\
\text { NGL(e) }\end{array}$ & \begin{tabular}{|c|}
$\begin{array}{c}\text { Coal } \\
\text { (excluding } \\
\text { coke and } \\
\text { breeze) }\end{array}$ \\
\end{tabular} & $\begin{array}{c}\text { Other } \\
\text { (f) }\end{array}$ & $\begin{array}{c}\text { Percent } \\
\text { waste } \\
\text { heat }\end{array}$ & $\begin{array}{l}\text { Waste heat } \\
\text { TBtu/year } \\
\text { Low temp }\end{array}$ \\
\hline & CHP and/or Cogeneration Process & $*$ & 1 & 24 & $*$ & 0 & - & $17.5 \%$ & 4.4 \\
\hline & Direct Uses-Total Process & $*$ & $*$ & 19 & $*$ & 0 & - & & \\
\hline & Process Heating & $*$ & $*$ & 16 & $*$ & 0 & - & $20 \%$ & 3.2 \\
\hline & End Use Not Reported & $\mathrm{Q}$ & $*$ & 2 & $*$ & 0 & 2 & & \\
\hline \multirow[t]{8}{*}{3116} & Animal Slaughtering and Processing & & & & & & & & \\
\hline & TOTAL FUEL CONSUMPTION & 5 & 3 & 125 & 2 & $\mathrm{Q}$ & 8 & $17.5 \%$ & 1.4 \\
\hline & Indirect Uses-Boiler Fuel & 4 & 1 & 80 & $\mathrm{Q}$ & 0 & - & & \\
\hline & Conventional Boiler Use & 2 & $*$ & 45 & $*$ & 0 & - & $17.5 \%$ & 8.2 \\
\hline & CHP and/or Cogeneration Process & 2 & 1 & 35 & $\mathrm{Q}$ & 0 & - & $17.5 \%$ & 6.7 \\
\hline & Direct Uses-Total Process & $*$ & $*$ & 29 & 1 & $\mathrm{Q}$ & - & & \\
\hline & Process Heating & $*$ & $*$ & 25 & 1 & $\mathrm{Q}$ & 一 & $20 \%$ & 5.2 \\
\hline & End Use Not Reported & $*$ & $*$ & 1 & $*$ & 0 & 8 & & \\
\hline \multirow[t]{8}{*}{312} & Beverage and Tobacco Products & & & & & & & & \\
\hline & TOTAL FUEL CONSUMPTION & 1 & 1 & 38 & 1 & 10 & 7 & $17.5 \%$ & 1.2 \\
\hline & Indirect Uses-Boiler Fuel & $*$ & $*$ & 24 & $*$ & 5 & - & & \\
\hline & Conventional Boiler Use & $*$ & $*$ & 9 & $*$ & 1 & - & $17.5 \%$ & 1.8 \\
\hline & CHP and/or Cogeneration Process & $*$ & $*$ & 15 & $*$ & 4 & - & $17.5 \%$ & 3.3 \\
\hline & Direct Uses-Total Process & $*$ & 1 & 9 & $*$ & 4 & - & & \\
\hline & Process Heating & $*$ & $*$ & 9 & $*$ & 4 & - & $20 \%$ & 2.6 \\
\hline & End Use Not Reported & 0 & $*$ & $*$ & $*$ & 0 & 7 & & \\
\hline \multirow[t]{8}{*}{3121} & Beverages & & & & & & & & \\
\hline & TOTAL FUEL CONSUMPTION & $*$ & 1 & 34 & 1 & 8 & 7 & $17.5 \%$ & 1.2 \\
\hline & Indirect Uses-Boiler Fuel & $*$ & $*$ & 21 & $*$ & 3 & - & & \\
\hline & Conventional Boiler Use & $*$ & $*$ & 8 & $*$ & $*$ & - & $17.5 \%$ & 1.4 \\
\hline & CHP and/or Cogeneration Process & $*$ & $*$ & 13 & $*$ & 3 & - & $17.5 \%$ & 2.8 \\
\hline & Direct Uses-Total Process & $*$ & 1 & 9 & $*$ & 4 & 一 & & \\
\hline & Process Heating & $*$ & $*$ & 8 & $*$ & 4 & - & $20 \%$ & 2.4 \\
\hline & End Use Not Reported & 0 & $*$ & $*$ & $*$ & 0 & 7 & & \\
\hline \multirow[t]{8}{*}{3122} & Tobacco & & & & & & & & \\
\hline & TOTAL FUEL CONSUMPTION & $*$ & $*$ & 4 & $*$ & 2 & $*$ & $17.5 \%$ & 0.0 \\
\hline & Indirect Uses-Boiler Fuel & $*$ & $*$ & 3 & $*$ & 2 & - & & \\
\hline & Conventional Boiler Use & $*$ & $*$ & 1 & $*$ & 1 & - & $17.5 \%$ & 0.4 \\
\hline & CHP and/or Cogeneration Process & 0 & $*$ & 2 & $*$ & 1 & - & $17.5 \%$ & 0.5 \\
\hline & Direct Uses-Total Process & $*$ & $*$ & $*$ & $*$ & 0 & - & & \\
\hline & Process Heating & $*$ & $*$ & $*$ & $*$ & 0 & - & $20 \%$ & 0.0 \\
\hline & End Use Not Reported & 0 & 0 & 0 & 0 & 0 & $*$ & & \\
\hline \multirow[t]{7}{*}{313} & Textile Mills & & & & & & & & \\
\hline & TOTAL FUEL CONSUMPTION & 2 & $\mathrm{Q}$ & 31 & 1 & 8 & 6 & $17.5 \%$ & 1.1 \\
\hline & Indirect Uses-Boiler Fuel & 1 & $*$ & 17 & $*$ & 7 & - & & \\
\hline & Conventional Boiler Use & $*$ & $*$ & 8 & $*$ & $\mathrm{Q}$ & - & $17.5 \%$ & 1.4 \\
\hline & CHP and/or Cogeneration Process & 1 & $*$ & 9 & $*$ & 2 & 一 & $17.5 \%$ & 2.1 \\
\hline & Direct Uses-Total Process & $\mathrm{Q}$ & Q & 11 & $*$ & $\mathrm{Q}$ & 一 & & \\
\hline & Process Heating & $\mathrm{Q}$ & $*$ & 10 & $*$ & $\mathrm{Q}$ & - & $20 \%$ & 2.0 \\
\hline \multirow[t]{4}{*}{314} & Textile Product Mills & & & & & & & & \\
\hline & TOTAL FUEL CONSUMPTION & $*$ & $*$ & 9 & $\mathrm{Q}$ & $\mathrm{Q}$ & $*$ & $17.5 \%$ & 0.0 \\
\hline & Indirect Uses-Boiler Fuel & $*$ & $*$ & 4 & $*$ & 0 & - & & \\
\hline & Conventional Boiler Use & $*$ & $*$ & 2 & $*$ & 0 & - & $17.5 \%$ & 0.4 \\
\hline
\end{tabular}




\begin{tabular}{|c|c|c|c|c|c|c|c|c|c|}
\hline $\begin{array}{l}\text { NAICS } \\
\text { code(a) }\end{array}$ & End use & $\begin{array}{l}\text { Residual } \\
\text { fuel oil }\end{array}$ & $\begin{array}{c}\text { Distillate } \\
\text { fuel oil } \\
\text { and } \\
\text { diesel } \\
\text { fuel(c) }\end{array}$ & $\begin{array}{c}\text { Natural } \\
\operatorname{gas}(d)\end{array}$ & $\begin{array}{c}\text { LPG and } \\
\text { NGL(e) }\end{array}$ & \begin{tabular}{|c|} 
Coal \\
(excluding \\
coke and \\
breeze)
\end{tabular} & $\begin{array}{c}\text { Other } \\
\text { (f) }\end{array}$ & $\begin{array}{c}\text { Percent } \\
\text { waste } \\
\text { heat }\end{array}$ & $\begin{array}{l}\text { Waste heat } \\
\text { TBtu/year } \\
\text { Low temp }\end{array}$ \\
\hline & CHP and/or Cogeneration Process & 0 & 0 & 2 & $*$ & 0 & 一 & $17.5 \%$ & 0.4 \\
\hline & Direct Uses-Total Process & 0 & $*$ & 3 & $*$ & $\mathrm{Q}$ & - & & \\
\hline & Process Heating & 0 & $*$ & 3 & $*$ & $\mathrm{Q}$ & - & $20 \%$ & 0.6 \\
\hline & End Use Not Reported & 0 & 0 & $*$ & $*$ & 0 & $*$ & & \\
\hline \multirow[t]{14}{*}{315} & Apparel & & & & & & & & \\
\hline & TOTAL FUEL CONSUMPTION & 0 & $*$ & 2 & $*$ & 0 & $*$ & $17.5 \%$ & 0.0 \\
\hline & Indirect Uses-Boiler Fuel & 0 & $*$ & 1 & $*$ & 0 & - & & \\
\hline & Conventional Boiler Use & 0 & 0 & $*$ & 0 & 0 & 一 & $17.5 \%$ & 0.0 \\
\hline & CHP and/or Cogeneration Process & 0 & $*$ & $*$ & $*$ & 0 & 一 & $17.5 \%$ & 0.0 \\
\hline & Direct Uses-Total Process & 0 & 0 & 1 & $*$ & 0 & 一 & & \\
\hline & Process Heating & 0 & 0 & 1 & $*$ & 0 & 一 & $20 \%$ & 0.2 \\
\hline & TOTAL FUEL CONSUMPTION & $*$ & $*$ & 1 & $*$ & 0 & $*$ & $17.5 \%$ & 0.0 \\
\hline & Indirect Uses-Boiler Fuel & 0 & $*$ & $*$ & $*$ & 0 & 一 & & \\
\hline & Conventional Boiler Use & 0 & $*$ & $*$ & $*$ & 0 & - & $17.5 \%$ & 0.0 \\
\hline & CHP and/or Cogeneration Process & 0 & $*$ & $*$ & $*$ & 0 & - & $17.5 \%$ & 0.0 \\
\hline & Direct Uses-Total Process & 0 & 0 & $*$ & $*$ & 0 & 一 & & \\
\hline & Process Heating & 0 & 0 & $*$ & $*$ & 0 & - & $20 \%$ & 0.0 \\
\hline & Total for NAICS 311 - 315 & & & & & & & Total & 169.1 \\
\hline \multirow[t]{8}{*}{321} & Wood Products & & & & & & & & \\
\hline & TOTAL FUEL CONSUMPTION & $*$ & 22 & 34 & 3 & 1 & 357 & $17.5 \%$ & 62.5 \\
\hline & Indirect Uses-Boiler Fuel & $*$ & $\mathrm{Q}$ & 8 & $*$ & 1 & - & & \\
\hline & Conventional Boiler Use & $*$ & $*$ & 2 & $*$ & $*$ & - & $17.5 \%$ & 0.4 \\
\hline & CHP and/or Cogeneration Process & $*$ & $\mathrm{Q}$ & 6 & $*$ & $*$ & 一 & $17.5 \%$ & 1.1 \\
\hline & Direct Uses-Total Process & $*$ & $\mathrm{Q}$ & 22 & 1 & $*$ & - & & \\
\hline & Process Heating & $*$ & $*$ & 21 & $*$ & $*$ & 一 & $20 \%$ & 4.2 \\
\hline & End Use Not Reported & * & $\mathrm{Q}$ & $*$ & $*$ & 0 & 357 & & \\
\hline \multirow[t]{8}{*}{321113} & Sawmills & & & & & & & & \\
\hline & TOTAL FUEL CONSUMPTION & $*$ & $\mathrm{Q}$ & 5 & $*$ & 0 & 195 & $17.5 \%$ & 34.1 \\
\hline & Indirect Uses-Boiler Fuel & $*$ & $*$ & 1 & $*$ & 0 & 一 & & \\
\hline & Conventional Boiler Use & 0 & $*$ & $*$ & $*$ & 0 & 一 & $17.5 \%$ & 0.0 \\
\hline & $\mathrm{CHP}$ and/or Cogeneration Process & * & $*$ & 1 & $*$ & 0 & - & $17.5 \%$ & 0.2 \\
\hline & Direct Uses-Total Process & $*$ & $\mathrm{Q}$ & 4 & $*$ & 0 & - & & \\
\hline & Process Heating & $*$ & $*$ & 4 & $*$ & 0 & - & $20 \%$ & 0.8 \\
\hline & End Use Not Reported & * & $\mathrm{Q}$ & $*$ & $*$ & 0 & 195 & & \\
\hline \multirow[t]{8}{*}{3212} & \begin{tabular}{|l} 
Veneer, Plywood, and Engineered \\
Woods \\
\end{tabular} & & & & & & & & \\
\hline & TOTAL FUEL CONSUMPTION & * & 2 & 19 & 1 & 1 & 138 & $17.5 \%$ & 24.2 \\
\hline & Indirect Uses-Boiler Fuel & $*$ & $\mathrm{Q}$ & 4 & $*$ & 1 & 一 & & \\
\hline & Conventional Boiler Use & $*$ & $*$ & 1 & $*$ & $*$ & 一 & $17.5 \%$ & 0.2 \\
\hline & CHP and/or Cogeneration Process & 0 & $\mathrm{Q}$ & 3 & $*$ & $*$ & 一 & $17.5 \%$ & 0.5 \\
\hline & Direct Uses-Total Process & $*$ & $*$ & 14 & $*$ & $*$ & - & & \\
\hline & Process Heating & $*$ & $*$ & 13 & $*$ & $*$ & - & $20 \%$ & 2.6 \\
\hline & End Use Not Reported & 0 & $*$ & $*$ & $*$ & 0 & 138 & & \\
\hline \multirow[t]{3}{*}{321219} & Reconstituted Wood Products & & & & & & & & \\
\hline & TOTAL FUEL CONSUMPTION & $*$ & $\mathrm{Q}$ & 14 & $*$ & 1 & 52 & $17.5 \%$ & 9.1 \\
\hline & Indirect Uses-Boiler Fuel & * & $\mathrm{Q}$ & 3 & $*$ & 1 & - & & \\
\hline
\end{tabular}




\begin{tabular}{|c|c|c|c|c|c|c|c|c|c|}
\hline $\begin{array}{l}\text { NAICS } \\
\text { code(a) }\end{array}$ & End use & $\begin{array}{c}\text { Residual } \\
\text { fuel oil }\end{array}$ & $\begin{array}{c}\text { Distillate } \\
\text { fuel oil } \\
\text { and } \\
\text { diesel } \\
\text { fuel(c) }\end{array}$ & $\begin{array}{c}\text { Natural } \\
\text { gas(d) }\end{array}$ & $\begin{array}{c}\text { LPG and } \\
\text { NGL(e) }\end{array}$ & $\begin{array}{c}\text { Coal } \\
\text { (excluding } \\
\text { coke and } \\
\text { breeze) }\end{array}$ & $\begin{array}{c}\text { Other } \\
\text { (f) }\end{array}$ & $\begin{array}{c}\text { Percent } \\
\text { waste } \\
\text { heat }\end{array}$ & $\begin{array}{l}\text { Waste heat } \\
\text { TBtu/year } \\
\text { Low temp }\end{array}$ \\
\hline & Conventional Boiler Use & $*$ & $*$ & 1 & $*$ & $*$ & - & $17.5 \%$ & 0.2 \\
\hline & CHP and/or Cogeneration Process & 0 & $\mathrm{Q}$ & 2 & 0 & $*$ & - & $17.5 \%$ & 0.4 \\
\hline & Direct Uses-Total Process & $*$ & $*$ & 11 & $*$ & $*$ & - & & \\
\hline & Process Heating & $*$ & $*$ & 11 & $*$ & $*$ & - & $20 \%$ & 2.2 \\
\hline & End Use Not Reported & 0 & 0 & $*$ & $*$ & 0 & 52 & & \\
\hline \multirow[t]{8}{*}{3219} & Other Wood Products & & & & & & & & \\
\hline & TOTAL FUEL CONSUMPTION & $*$ & 5 & 7 & 2 & $*$ & 20 & $17.5 \%$ & 3.5 \\
\hline & Indirect Uses-Boiler Fuel & 0 & $*$ & 2 & $*$ & 0 & - & & \\
\hline & Conventional Boiler Use & 0 & $*$ & 1 & $*$ & 0 & - & $17.5 \%$ & 0.2 \\
\hline & CHP and/or Cogeneration Process & 0 & $*$ & 1 & $*$ & 0 & - & $17.5 \%$ & 0.2 \\
\hline & Direct Uses-Total Process & 0 & 1 & 3 & $*$ & $*$ & - & & \\
\hline & Process Heating & 0 & $*$ & 3 & $*$ & $*$ & - & $20 \%$ & 0.6 \\
\hline & End Use Not Reported & $*$ & $*$ & $*$ & $*$ & 0 & 20 & & \\
\hline \multirow[t]{8}{*}{322} & Paper & & & & & & & & \\
\hline & TOTAL FUEL CONSUMPTION & 35 & 6 & 399 & 4 & 207 & 1,253 & $17.5 \%$ & 219.3 \\
\hline & Indirect Uses-Boiler Fuel & 23 & 3 & 240 & $*$ & 201 & - & & \\
\hline & Conventional Boiler Use & 7 & $*$ & 50 & $*$ & 7 & - & $17.5 \%$ & 11.2 \\
\hline & CHP and/or Cogeneration Process & 17 & 2 & 190 & $*$ & 194 & - & $17.5 \%$ & 70.5 \\
\hline & Direct Uses-Total Process & 11 & 1 & 132 & 1 & 6 & - & & \\
\hline & Process Heating & 10 & 1 & 120 & $*$ & 4 & - & $20 \%$ & 27.0 \\
\hline & Total for NAICS 321 - 322 & & & & & & & Total & 406.8 \\
\hline \multirow[t]{7}{*}{323} & Printing and Related Support & & & & & & & & \\
\hline & TOTAL FUEL CONSUMPTION & Q & $*$ & 34 & 1 & 0 & $*$ & $17.5 \%$ & 0.0 \\
\hline & Indirect Uses-Boiler Fuel & 0 & $*$ & 7 & $*$ & 0 & - & & \\
\hline & Conventional Boiler Use & 0 & 0 & 3 & $*$ & 0 & - & $17.5 \%$ & 0.5 \\
\hline & CHP and/or Cogeneration Process & 0 & $*$ & 5 & $*$ & 0 & - & $17.5 \%$ & 0.9 \\
\hline & Direct Uses-Total Process & 0 & $*$ & 16 & $*$ & 0 & - & & \\
\hline & Process Heating & 0 & $*$ & 12 & $*$ & 0 & - & $20 \%$ & 2.4 \\
\hline \multirow[t]{8}{*}{324} & Petroleum and Coal Products & & & & & & & & \\
\hline & TOTAL FUEL CONSUMPTION & 17 & 24 & 918 & 26 & 11 & 2,162 & $17.5 \%$ & 378.4 \\
\hline & Indirect Uses-Boiler Fuel & 4 & 7 & 298 & 7 & 3 & - & & \\
\hline & Conventional Boiler Use & 4 & $*$ & 102 & 2 & 1 & - & $17.5 \%$ & 19.1 \\
\hline & CHP and/or Cogeneration Process & 1 & 7 & 196 & 5 & 2 & - & $17.5 \%$ & 36.9 \\
\hline & Direct Uses-Total Process & 10 & 11 & 567 & 18 & 9 & - & & \\
\hline & Process Heating & 10 & 7 & 516 & 18 & 4 & 一 & $20 \%$ & 111.0 \\
\hline & End Use Not Reported & 2 & 1 & 34 & 1 & 0 & 2,162 & & \\
\hline \multirow[t]{8}{*}{324110} & Petroleum Refineries & & & & & & & & \\
\hline & TOTAL FUEL CONSUMPTION & 14 & 11 & 859 & 25 & 1 & 2,113 & $17.5 \%$ & 369.8 \\
\hline & Indirect Uses-Boiler Fuel & 4 & 6 & 286 & 7 & 1 & - & & \\
\hline & Conventional Boiler Use & 4 & $*$ & 98 & 2 & 1 & 一 & $17.5 \%$ & 18.4 \\
\hline & CHP and/or Cogeneration Process & $*$ & 6 & 188 & 5 & 0 & 一 & $10 \%$ & 19.9 \\
\hline & Direct Uses-Total Process & 7 & 2 & 524 & 17 & 0 & - & & \\
\hline & Process Heating & 7 & 1 & 475 & 17 & 0 & - & $20 \%$ & 100.0 \\
\hline & End Use Not Reported & 2 & $*$ & 33 & 1 & 0 & 2,113 & & \\
\hline \multirow[t]{2}{*}{324121} & Asphalt Paving Mixture and Block & & & & & & & & \\
\hline & TOTAL FUEL CONSUMPTION & 3 & 12 & 39 & 1 & $\mathrm{Q}$ & 6 & $17.5 \%$ & 1.1 \\
\hline
\end{tabular}




\begin{tabular}{|c|c|c|c|c|c|c|c|c|c|}
\hline $\begin{array}{l}\text { NAICS } \\
\text { code(a) }\end{array}$ & End use & $\begin{array}{c}\text { Residual } \\
\text { fuel oil }\end{array}$ & $\begin{array}{c}\text { Distillate } \\
\text { fuel oil } \\
\text { and } \\
\text { diesel } \\
\text { fuel(c) }\end{array}$ & $\begin{array}{c}\text { Natural } \\
\text { gas(d) }\end{array}$ & $\begin{array}{c}\text { LPG and } \\
\text { NGL(e) }\end{array}$ & $\begin{array}{c}\text { Coal } \\
\text { (excluding } \\
\text { coke and } \\
\text { breeze) }\end{array}$ & $\begin{array}{c}\text { Other } \\
\text { (f) }\end{array}$ & $\begin{array}{c}\text { Percent } \\
\text { waste } \\
\text { heat }\end{array}$ & $\begin{array}{l}\text { Waste heat } \\
\text { TBtu/year } \\
\text { Low temp }\end{array}$ \\
\hline & Indirect Uses-Boiler Fuel & $*$ & $*$ & 5 & $*$ & 0 & - & & \\
\hline & Conventional Boiler Use & $*$ & $*$ & 2 & $*$ & 0 & - & $17.5 \%$ & 0.4 \\
\hline & $\mathrm{CHP}$ and/or Cogeneration Process & 0 & $*$ & 3 & $*$ & 0 & - & $17.5 \%$ & 0.5 \\
\hline & Direct Uses-Total Process & 3 & 8 & 33 & 1 & $\mathrm{Q}$ & - & & \\
\hline & Process Heating & 3 & 6 & 30 & 1 & Q & - & $20 \%$ & 8.0 \\
\hline & End Use Not Reported & $*$ & $*$ & $\mathrm{Q}$ & $*$ & 0 & 6 & & \\
\hline \multirow[t]{8}{*}{324199} & Other Petroleum and Coal Products & & & & & & & & \\
\hline & TOTAL FUEL CONSUMPTION & $*$ & $*$ & 5 & $*$ & 9 & 41 & $17.5 \%$ & 7.2 \\
\hline & Indirect Uses-Boiler Fuel & $*$ & 0 & 1 & 0 & 1 & - & & \\
\hline & Conventional Boiler Use & $*$ & 0 & $*$ & 0 & $*$ & - & $17.5 \%$ & 0.0 \\
\hline & CHP and/or Cogeneration Process & $*$ & 0 & 1 & 0 & 1 & - & $17.5 \%$ & 0.4 \\
\hline & Direct Uses-Total Process & 0 & $*$ & 4 & $*$ & 8 & - & & \\
\hline & Process Heating & 0 & $*$ & 4 & $*$ & 3 & - & $20 \%$ & 1.4 \\
\hline & End Use Not Reported & 0 & 0 & 0 & $*$ & 0 & 41 & & \\
\hline \multirow[t]{7}{*}{325} & Chemicals & & & & & & & & \\
\hline & TOTAL FUEL CONSUMPTION & 7 & 8 & 1,784 & 7 & 200 & 765 & $17.5 \%$ & 133.9 \\
\hline & Indirect Uses-Boiler Fuel & 4 & 2 & 1,000 & 1 & 187 & - & & \\
\hline & Conventional Boiler Use & 2 & 1 & 302 & 1 & 29 & - & $17.5 \%$ & 58.6 \\
\hline & CHP and/or Cogeneration Process & 3 & 1 & 697 & $*$ & 158 & - & $17.5 \%$ & 150.3 \\
\hline & Direct Uses-Total Process & 2 & 2 & 750 & 1 & 13 & - & & \\
\hline & Process Heating & 2 & 1 & 624 & $*$ & 13 & - & $20 \%$ & 128.0 \\
\hline \multirow[t]{7}{*}{326} & Plastics and Rubber Products & & & & & & & & \\
\hline & TOTAL FUEL CONSUMPTION & $*$ & 2 & 103 & 2 & $\mathrm{Q}$ & $\mathrm{Q}$ & $17.5 \%$ & 0.0 \\
\hline & Indirect Uses-Boiler Fuel & $*$ & 2 & 44 & $*$ & $\mathrm{Q}$ & - & & \\
\hline & Conventional Boiler Use & $*$ & Q & 20 & $*$ & 0 & - & $17.5 \%$ & 3.5 \\
\hline & CHP and/or Cogeneration Process & 0 & 1 & 24 & $*$ & $Q$ & - & $17.5 \%$ & 4.4 \\
\hline & Direct Uses-Total Process & 0 & $*$ & 37 & $*$ & 0 & - & & \\
\hline & Process Heating & 0 & 0 & 34 & $*$ & 0 & - & $20 \%$ & 6.8 \\
\hline \multirow[t]{8}{*}{327} & Nonmetallic Mineral Products & & & & & & & & \\
\hline & TOTAL FUEL CONSUMPTION & 1 & 23 & 273 & 2 & 217 & 83 & $17.5 \%$ & 14.5 \\
\hline & Indirect Uses-Boiler Fuel & $*$ & $*$ & 11 & $*$ & $*$ & - & & \\
\hline & Conventional Boiler Use & 0 & $*$ & 3 & $*$ & 0 & - & $17.5 \%$ & 0.5 \\
\hline & CHP and/or Cogeneration Process & $*$ & $*$ & 7 & $*$ & $*$ & - & $17.5 \%$ & 1.2 \\
\hline & Direct Uses-Total Process & 1 & 12 & 239 & 1 & 216 & - & & \\
\hline & Process Heating & $*$ & 2 & 235 & 1 & 216 & - & $20 \%$ & 90.8 \\
\hline & End Use Not Reported & 0 & $*$ & 6 & $*$ & 0 & 83 & & \\
\hline \multirow[t]{8}{*}{327121} & Brick and Structural Clay Tile & & & & & & & & \\
\hline & TOTAL FUEL CONSUMPTION & $*$ & $*$ & 16 & $*$ & 1 & 1 & $17.5 \%$ & 0.2 \\
\hline & Indirect Uses-Boiler Fuel & 0 & 0 & $*$ & 0 & 0 & - & & \\
\hline & Conventional Boiler Use & 0 & 0 & $*$ & 0 & 0 & - & $17.5 \%$ & 0.0 \\
\hline & CHP and/or Cogeneration Process & 0 & 0 & $*$ & 0 & 0 & - & $17.5 \%$ & 0.0 \\
\hline & Direct Uses-Total Process & $*$ & $*$ & 15 & $*$ & 1 & - & & \\
\hline & Process Heating & $*$ & $*$ & 15 & $*$ & 1 & - & $20 \%$ & 3.2 \\
\hline & End Use Not Reported & 0 & 0 & 1 & $*$ & 0 & 1 & & \\
\hline \multirow[t]{3}{*}{327211} & Flat Glass & & & & & & & & \\
\hline & TOTAL FUEL CONSUMPTION & 0 & $*$ & 43 & $*$ & 0 & $*$ & $17.5 \%$ & 0.0 \\
\hline & Indirect Uses-Boiler Fuel & 0 & 0 & $*$ & 0 & 0 & - & & \\
\hline
\end{tabular}




\begin{tabular}{|c|c|c|c|c|c|c|c|c|c|}
\hline $\begin{array}{l}\text { NAICS } \\
\operatorname{code}(a)\end{array}$ & End use & $\begin{array}{c}\text { Residual } \\
\text { fuel oil }\end{array}$ & $\begin{array}{c}\text { Distillate } \\
\text { fuel oil } \\
\text { and } \\
\text { diesel } \\
\text { fuel(c) } \\
\end{array}$ & $\begin{array}{c}\text { Natural } \\
\operatorname{gas}(d)\end{array}$ & $\begin{array}{c}\text { LPG and } \\
\text { NGL(e) }\end{array}$ & \begin{tabular}{|c|}
$\begin{array}{c}\text { Coal } \\
\text { (excluding } \\
\text { coke and } \\
\text { breeze) }\end{array}$ \\
\end{tabular} & $\begin{array}{c}\text { Other } \\
\text { (f) }\end{array}$ & $\begin{array}{c}\text { Percent } \\
\text { waste } \\
\text { heat }\end{array}$ & $\begin{array}{l}\text { Waste heat } \\
\text { TBtu/year } \\
\text { Low temp" }\end{array}$ \\
\hline & Conventional Boiler Use & 0 & \begin{tabular}{r|}
0 \\
\end{tabular} & $*$ & 0 & 0 & - & $17.5 \%$ & 0.0 \\
\hline & CHP and/or Cogeneration Process & 0 & 0 & 0 & 0 & 0 & - & $17.5 \%$ & 0.0 \\
\hline & Direct Uses-Total Process & 0 & $*$ & 41 & $*$ & 0 & - & & \\
\hline & Process Heating & 0 & $*$ & 41 & $*$ & 0 & - & $30 \%$ & 12.3 \\
\hline & End Use Not Reported & 0 & 0 & 0 & $*$ & 0 & $*$ & & \\
\hline \multirow[t]{8}{*}{327212} & $\begin{array}{l}\text { Other Pressed and Blown Glass and } \\
\text { Glassware }\end{array}$ & & & & & & & & \\
\hline & TOTAL FUEL CONSUMPTION & 0 & $*$ & 28 & $*$ & 0 & $\mathrm{Q}$ & $17.5 \%$ & 0.0 \\
\hline & Indirect Uses-Boiler Fuel & 0 & $*$ & 1 & $*$ & 0 & - & & \\
\hline & Conventional Boiler Use & 0 & $*$ & $*$ & $*$ & 0 & - & $17.5 \%$ & 0.0 \\
\hline & CHP and/or Cogeneration Process & 0 & 0 & 1 & $*$ & 0 & - & $17.5 \%$ & 0.2 \\
\hline & Direct Uses-Total Process & 0 & $*$ & 25 & $*$ & 0 & - & & \\
\hline & Process Heating & 0 & $*$ & 24 & $*$ & 0 & - & $30 \%$ & 7.2 \\
\hline & End Use Not Reported & 0 & 0 & 1 & $*$ & 0 & $\mathrm{Q}$ & & \\
\hline \multirow[t]{8}{*}{327213} & Glass Containers & & & & & & & & \\
\hline & TOTAL FUEL CONSUMPTION & 0 & $*$ & 46 & $*$ & 0 & $*$ & $17.5 \%$ & 0.0 \\
\hline & Indirect Uses-Boiler Fuel & 0 & 0 & $*$ & 0 & 0 & - & & \\
\hline & Conventional Boiler Use & 0 & 0 & $*$ & 0 & 0 & - & $17.5 \%$ & 0.0 \\
\hline & CHP and/or Cogeneration Process & 0 & 0 & $*$ & 0 & 0 & - & $17.5 \%$ & 0.0 \\
\hline & Direct Uses-Total Process & 0 & $*$ & 44 & $*$ & 0 & - & & \\
\hline & Process Heating & 0 & $*$ & 44 & $*$ & 0 & - & $30 \%$ & 13.2 \\
\hline & End Use Not Reported & 0 & $*$ & 0 & $*$ & 0 & $*$ & & \\
\hline \multirow[t]{8}{*}{327215} & Glass Products from Purchased Glass & & & & & & & & \\
\hline & TOTAL FUEL CONSUMPTION & 0 & $*$ & 5 & $*$ & $*$ & $*$ & & \\
\hline & Indirect Uses-Boiler Fuel & 0 & 0 & $*$ & 0 & 0 & - & $17.5 \%$ & 0.0 \\
\hline & Conventional Boiler Use & 0 & 0 & $*$ & 0 & 0 & - & & \\
\hline & $\mathrm{CHP}$ and/or Cogeneration Process & 0 & 0 & $*$ & 0 & 0 & - & $17.5 \%$ & 0.0 \\
\hline & Direct Uses-Total Process & 0 & $*$ & 3 & $*$ & 0 & - & $17.5 \%$ & 0.5 \\
\hline & Process Heating & 0 & $*$ & 3 & $*$ & 0 & 一 & $30 \%$ & 0.9 \\
\hline & End Use Not Reported & 0 & $*$ & $*$ & $*$ & 0 & $*$ & & \\
\hline \multirow[t]{8}{*}{327310} & Cements & & & & & & & & \\
\hline & TOTAL FUEL CONSUMPTION & $*$ & 3 & 13 & $*$ & 135 & 63 & $17.5 \%$ & 11.0 \\
\hline & Indirect Uses-Boiler Fuel & 0 & 0 & $*$ & $*$ & 0 & - & & \\
\hline & Conventional Boiler Use & 0 & 0 & $*$ & $*$ & 0 & 一 & $17.5 \%$ & 0.0 \\
\hline & $\mathrm{CHP}$ and/or Cogeneration Process & 0 & 0 & 0 & 0 & 0 & - & $17.5 \%$ & 0.0 \\
\hline & Direct Uses-Total Process & $*$ & 1 & 12 & $*$ & 135 & - & & \\
\hline & Process Heating & $*$ & $*$ & 12 & $*$ & 135 & - & $20 \%$ & 29.4 \\
\hline & End Use Not Reported & 0 & 0 & 0 & $*$ & 0 & 63 & & \\
\hline \multirow[t]{8}{*}{327410} & Lime & & & & & & & & \\
\hline & TOTAL FUEL CONSUMPTION & $*$ & 5 & 3 & $*$ & 77 & 11 & $17.5 \%$ & 1.9 \\
\hline & Indirect Uses-Boiler Fuel & 0 & 0 & $*$ & 0 & 0 & 一 & & \\
\hline & Conventional Boiler Use & 0 & 0 & $*$ & 0 & 0 & - & $17.5 \%$ & 0.0 \\
\hline & $\mathrm{CHP}$ and/or Cogeneration Process & 0 & 0 & 0 & 0 & 0 & - & $17.5 \%$ & 0.0 \\
\hline & Direct Uses-Total Process & 0 & 4 & 3 & $*$ & 77 & 一 & & \\
\hline & Process Heating & 0 & $*$ & 3 & $*$ & 77 & - & $20 \%$ & 16.0 \\
\hline & End Use Not Reported & 0 & 0 & 0 & $*$ & 0 & 11 & & \\
\hline 327420 & Gypsum & & & & & & & & \\
\hline
\end{tabular}




\begin{tabular}{|c|c|c|c|c|c|c|c|c|c|}
\hline $\begin{array}{l}\text { NAICS } \\
\operatorname{code}(\mathbf{a})\end{array}$ & End use & $\begin{array}{c}\text { Residual } \\
\text { fuel oil }\end{array}$ & $\begin{array}{c}\text { Distillate } \\
\text { fuel oil } \\
\text { and } \\
\text { diesel } \\
\text { fuel(c) } \\
\end{array}$ & $\begin{array}{c}\text { Natural } \\
\operatorname{gas}(d)\end{array}$ & $\begin{array}{c}\text { LPG and } \\
\text { NGL(e) }\end{array}$ & \begin{tabular}{|c|}
$\begin{array}{c}\text { Coal } \\
\text { (excluding } \\
\text { coke and } \\
\text { breeze) }\end{array}$ \\
\end{tabular} & $\begin{array}{c}\text { Other } \\
\text { (f) }\end{array}$ & $\begin{array}{c}\text { Percent } \\
\text { waste } \\
\text { heat }\end{array}$ & $\begin{array}{l}\text { Waste heat } \\
\text { TBtu/year } \\
\text { Low temp" }\end{array}$ \\
\hline & TOTAL FUEL CONSUMPTION & $*$ & $*$ & 39 & $*$ & 0 & $*$ & $17.5 \%$ & 0.0 \\
\hline & Indirect Uses-Boiler Fuel & 0 & 0 & 1 & 0 & 0 & - & & \\
\hline & Conventional Boiler Use & 0 & 0 & $*$ & 0 & 0 & - & $17.5 \%$ & 0.0 \\
\hline & CHP and/or Cogeneration Process & 0 & 0 & $*$ & 0 & 0 & - & $17.5 \%$ & 0.0 \\
\hline & Direct Uses-Total Process & 0 & $*$ & 36 & $*$ & 0 & - & & \\
\hline & Process Heating & 0 & $*$ & 35 & $*$ & 0 & - & $20 \%$ & 7.0 \\
\hline & End Use Not Reported & 0 & 0 & 0 & 0 & 0 & $*$ & & \\
\hline \multirow[t]{9}{*}{327993} & Mineral Wool & & & & & & & & \\
\hline & TOTAL FUEL CONSUMPTION & 0 & $*$ & 24 & $*$ & 0 & 3 & $17.5 \%$ & 0.5 \\
\hline & Indirect Uses-Boiler Fuel & 0 & $*$ & 1 & 0 & 0 & - & & \\
\hline & Conventional Boiler Use & 0 & 0 & $*$ & 0 & 0 & 一 & $17.5 \%$ & 0.0 \\
\hline & CHP and/or Cogeneration Process & 0 & $*$ & 1 & 0 & 0 & - & $17.5 \%$ & 0.2 \\
\hline & Direct Uses-Total Process & 0 & $*$ & 21 & $*$ & 0 & - & & \\
\hline & Process Heating & 0 & $*$ & 21 & $*$ & 0 & - & $30 \%$ & 6.3 \\
\hline & End Use Not Reported & 0 & 0 & 0 & 0 & 0 & 3 & & \\
\hline & Total for NAICS 323 - 327 & & & & & & & Total & $1,126.2$ \\
\hline \multirow[t]{7}{*}{331} & Primary Metals & & & & & & & & \\
\hline & TOTAL FUEL CONSUMPTION & 1 & 9 & 537 & 3 & 23 & 682 & $20 \%$ & 136.4 \\
\hline & Indirect Uses-Boiler Fuel & 1 & $*$ & 63 & $*$ & 0 & - & & \\
\hline & Conventional Boiler Use & $*$ & $*$ & 22 & $*$ & 0 & - & $17.5 \%$ & 3.9 \\
\hline & CHP and/or Cogeneration Process & $*$ & $*$ & 42 & $*$ & 0 & - & $17.5 \%$ & 7.4 \\
\hline & Direct Uses-Total Process & $*$ & 3 & 434 & 1 & 21 & - & & \\
\hline & Process Heating & $*$ & $*$ & 403 & 1 & 21 & 一 & $30 \%$ & 127.5 \\
\hline \multirow[t]{7}{*}{331111} & Iron and Steel Mills & & & & & & & & \\
\hline & TOTAL FUEL CONSUMPTION & $*$ & 5 & 325 & $*$ & 23 & 633 & $20 \%$ & 126.6 \\
\hline & Indirect Uses-Boiler Fuel & $*$ & $*$ & 38 & $*$ & 0 & - & & \\
\hline & Conventional Boiler Use & $*$ & $*$ & $\mathrm{~W}$ & $*$ & 0 & - & $17.5 \%$ & 0.0 \\
\hline & CHP and/or Cogeneration Process & $*$ & $*$ & $\mathrm{~W}$ & $*$ & 0 & - & $17.5 \%$ & 0.0 \\
\hline & Direct Uses-Total Process & 0 & 2 & 272 & $*$ & 21 & - & & \\
\hline & Process Heating & 0 & $*$ & 252 & $*$ & 21 & - & $30 \%$ & 81.9 \\
\hline \multirow[t]{7}{*}{331112} & \begin{tabular}{|l|}
$\begin{array}{l}\text { Electrometallurgical Ferroalloy } \\
\text { Products }\end{array}$ \\
\end{tabular} & & & & & & & & \\
\hline & TOTAL FUEL CONSUMPTION & 0 & $*$ & 1 & $*$ & 0 & 1 & $20 \%$ & 0.2 \\
\hline & Indirect Uses-Boiler Fuel & 0 & 0 & $*$ & 0 & 0 & - & & \\
\hline & Conventional Boiler Use & 0 & 0 & $*$ & 0 & 0 & 一 & $17.5 \%$ & 0.0 \\
\hline & CHP and/or Cogeneration Process & 0 & 0 & $*$ & 0 & 0 & - & $17.5 \%$ & 0.0 \\
\hline & Direct Uses-Total Process & 0 & $*$ & 1 & $*$ & 0 & - & & \\
\hline & Process Heating & 0 & $*$ & 1 & $*$ & 0 & 一 & $30 \%$ & 0.3 \\
\hline \multirow[t]{7}{*}{3312} & Steel Products from Purchased Steel & & & & & & & & \\
\hline & TOTAL FUEL CONSUMPTION & $*$ & $*$ & 18 & $*$ & 0 & 7 & $20 \%$ & 1.4 \\
\hline & Indirect Uses-Boiler Fuel & 0 & $*$ & 2 & $*$ & 0 & - & & \\
\hline & Conventional Boiler Use & 0 & 0 & 1 & $*$ & 0 & - & $17.5 \%$ & 0.2 \\
\hline & $\mathrm{CHP}$ and/or Cogeneration Process & 0 & $*$ & 1 & 0 & 0 & 一 & $17.5 \%$ & 0.2 \\
\hline & Direct Uses-Total Process & $*$ & $*$ & 13 & $*$ & 0 & - & & \\
\hline & Process Heating & 0 & $*$ & 12 & $*$ & 0 & - & $30 \%$ & 3.6 \\
\hline 3313 & Alumina and Aluminum & & & & & & & & \\
\hline
\end{tabular}




\begin{tabular}{|c|c|c|c|c|c|c|c|c|c|}
\hline $\begin{array}{l}\text { NAICS } \\
\text { code(a) }\end{array}$ & End use & $\begin{array}{c}\text { Residual } \\
\text { fuel oil }\end{array}$ & $\begin{array}{c}\text { Distillate } \\
\text { fuel oil } \\
\text { and } \\
\text { diesel } \\
\text { fuel(c) }\end{array}$ & $\begin{array}{c}\text { Natural } \\
\text { gas(d) }\end{array}$ & $\begin{array}{c}\text { LPG and } \\
\text { NGL(e) }\end{array}$ & $\begin{array}{c}\text { Coal } \\
\text { (excluding } \\
\text { coke and } \\
\text { breeze) }\end{array}$ & $\begin{array}{c}\text { Other } \\
\text { (f) }\end{array}$ & $\begin{array}{c}\text { Percent } \\
\text { waste } \\
\text { heat }\end{array}$ & $\begin{array}{l}\text { Waste heat } \\
\text { TBtu/year } \\
\text { Low temp }\end{array}$ \\
\hline & TOTAL FUEL CONSUMPTION & $*$ & 2 & 96 & 1 & 0 & 5 & $20 \%$ & 1.0 \\
\hline & Indirect Uses-Boiler Fuel & $*$ & $*$ & 13 & $*$ & 0 & - & & \\
\hline & Conventional Boiler Use & $*$ & $*$ & $\mathrm{~W}$ & $*$ & 0 & - & $17.5 \%$ & 0.0 \\
\hline & CHP and/or Cogeneration Process & 0 & 0 & $\mathrm{~W}$ & 0 & 0 & - & $17.5 \%$ & 0.0 \\
\hline & Direct Uses-Total Process & $*$ & 1 & 78 & $*$ & 0 & - & & \\
\hline & Process Heating & $*$ & $*$ & 73 & $*$ & 0 & - & $20 \%$ & 14.6 \\
\hline \multirow[t]{7}{*}{331314} & $\begin{array}{l}\text { Secondary Smelting and Alloying of } \\
\text { Aluminum }\end{array}$ & & & & & & & & \\
\hline & TOTAL FUEL CONSUMPTION & $*$ & $*$ & 14 & $*$ & 0 & $*$ & $20 \%$ & 0.0 \\
\hline & Indirect Uses-Boiler Fuel & 0 & 0 & 1 & 0 & 0 & 一 & & \\
\hline & Conventional Boiler Use & 0 & 0 & 0 & 0 & 0 & - & $17.5 \%$ & 0.0 \\
\hline & CHP and/or Cogeneration Process & 0 & 0 & 1 & 0 & 0 & - & $17.5 \%$ & 0.2 \\
\hline & Direct Uses-Total Process & $*$ & $*$ & 13 & $*$ & 0 & - & & \\
\hline & Process Heating & $*$ & $*$ & 13 & $*$ & 0 & - & $40 \%$ & 5.2 \\
\hline \multirow[t]{7}{*}{331315} & Aluminum Sheet, Plate, and Foils & & & & & & & & \\
\hline & TOTAL FUEL CONSUMPTION & $*$ & $*$ & 40 & $*$ & 0 & 2 & $20 \%$ & 0.4 \\
\hline & Indirect Uses-Boiler Fuel & $*$ & 0 & $\mathrm{~W}$ & 0 & 0 & - & & \\
\hline & Conventional Boiler Use & $*$ & 0 & 1 & 0 & 0 & - & $17.5 \%$ & 0.2 \\
\hline & CHP and/or Cogeneration Process & 0 & 0 & W & 0 & 0 & - & $17.5 \%$ & 0.0 \\
\hline & Direct Uses-Total Process & $*$ & $*$ & 37 & $*$ & 0 & 一 & & \\
\hline & Process Heating & $*$ & 0 & 37 & $*$ & 0 & - & $30 \%$ & 11.1 \\
\hline \multirow[t]{7}{*}{331316} & Aluminum Extruded Products & & & & & & & & \\
\hline & TOTAL FUEL CONSUMPTION & 0 & $*$ & 11 & $*$ & 0 & $*$ & $20 \%$ & 0.0 \\
\hline & Indirect Uses-Boiler Fuel & 0 & 0 & W & $*$ & 0 & - & & \\
\hline & Conventional Boiler Use & 0 & 0 & $\mathrm{~W}$ & $*$ & 0 & - & $17.5 \%$ & 0.0 \\
\hline & CHP and/or Cogeneration Process & 0 & 0 & $\mathrm{~W}$ & 0 & 0 & - & $17.5 \%$ & 0.0 \\
\hline & Direct Uses-Total Process & 0 & $*$ & $\mathrm{~W}$ & $*$ & 0 & - & & \\
\hline & Process Heating & 0 & 0 & $\mathrm{~W}$ & $*$ & 0 & - & $30 \%$ & 0.0 \\
\hline \multirow[t]{7}{*}{3314} & Nonferrous Metals, except Aluminum & & & & & & & & \\
\hline & TOTAL FUEL CONSUMPTION & $*$ & $*$ & 51 & 1 & 0 & 25 & $20 \%$ & 5.0 \\
\hline & Indirect Uses-Boiler Fuel & 0 & $*$ & 9 & $*$ & 0 & - & & \\
\hline & Conventional Boiler Use & 0 & $*$ & 4 & $*$ & 0 & - & $17.5 \%$ & 0.7 \\
\hline & CHP and/or Cogeneration Process & 0 & $*$ & 5 & $*$ & 0 & - & $17.5 \%$ & 0.9 \\
\hline & Direct Uses-Total Process & 0 & $*$ & 37 & 1 & 0 & - & & \\
\hline & Process Heating & 0 & $*$ & 33 & 1 & 0 & - & $30 \%$ & 10.2 \\
\hline \multirow[t]{7}{*}{331419} & $\begin{array}{l}\text { Primary Smelting and Refining of } \\
\text { Nonferrous Metals, except Copper } \\
\text { and Aluminum }\end{array}$ & & & & & & & & \\
\hline & TOTAL FUEL CONSUMPTION & 0 & $*$ & 12 & $*$ & 0 & 22 & $20 \%$ & 4.4 \\
\hline & Indirect Uses-Boiler Fuel & 0 & $*$ & 1 & 0 & 0 & - & & \\
\hline & Conventional Boiler Use & 0 & 0 & $*$ & 0 & 0 & - & $17.5 \%$ & 0.0 \\
\hline & CHP and/or Cogeneration Process & 0 & $*$ & 1 & 0 & 0 & - & $17.5 \%$ & 0.2 \\
\hline & Direct Uses-Total Process & 0 & $*$ & 11 & $*$ & 0 & - & & \\
\hline & Process Heating & 0 & $*$ & 8 & $*$ & 0 & - & $30 \%$ & 2.4 \\
\hline \multirow[t]{4}{*}{3315} & Foundries & & & & & & & & \\
\hline & TOTAL FUEL CONSUMPTION & 0 & 1 & 46 & 1 & 0 & 11 & $20 \%$ & 2.2 \\
\hline & Indirect Uses-Boiler Fuel & 0 & $*$ & 1 & $*$ & 0 & - & & \\
\hline & Conventional Boiler Use & 0 & $*$ & 1 & $*$ & 0 & - & $17.5 \%$ & 0.2 \\
\hline
\end{tabular}




\begin{tabular}{|c|c|c|c|c|c|c|c|c|c|}
\hline $\begin{array}{l}\text { NAICS } \\
\text { code(a) }\end{array}$ & End use & $\begin{array}{c}\text { Residual } \\
\text { fuel oil }\end{array}$ & $\begin{array}{c}\text { Distillate } \\
\text { fuel oil } \\
\text { and } \\
\text { diesel } \\
\text { fuel(c) }\end{array}$ & $\begin{array}{c}\text { Natural } \\
\text { gas(d) }\end{array}$ & $\begin{array}{c}\text { LPG and } \\
\text { NGL(e) }\end{array}$ & $\begin{array}{c}\text { Coal } \\
\text { (excluding } \\
\text { coke and } \\
\text { breeze) }\end{array}$ & $\begin{array}{c}\text { Other } \\
\text { (f) }\end{array}$ & $\begin{array}{c}\text { Percent } \\
\text { waste } \\
\text { heat }\end{array}$ & $\begin{array}{l}\text { Waste heat } \\
\text { TBtu/year } \\
\text { Low temp }\end{array}$ \\
\hline & CHP and/or Cogeneration Process & 0 & $*$ & 1 & $*$ & 0 & 一 & $17.5 \%$ & 0.2 \\
\hline & Direct Uses-Total Process & 0 & $*$ & 34 & $*$ & 0 & - & & \\
\hline & Process Heating & 0 & $*$ & 32 & $*$ & 0 & - & $30 \%$ & 9.6 \\
\hline \multirow[t]{7}{*}{331511} & Iron Foundries & & & & & & & & \\
\hline & TOTAL FUEL CONSUMPTION & 0 & $*$ & 14 & $*$ & 0 & 11 & $20 \%$ & 2.2 \\
\hline & Indirect Uses-Boiler Fuel & 0 & $*$ & $*$ & $*$ & 0 & - & & \\
\hline & Conventional Boiler Use & 0 & $*$ & $*$ & $*$ & 0 & - & $17.5 \%$ & 0.0 \\
\hline & CHP and/or Cogeneration Process & 0 & $*$ & $*$ & 0 & 0 & - & $17.5 \%$ & 0.0 \\
\hline & Direct Uses-Total Process & 0 & $*$ & 9 & $*$ & 0 & - & & \\
\hline & Process Heating & 0 & $*$ & 8 & $*$ & 0 & - & $30 \%$ & 2.4 \\
\hline \multirow[t]{7}{*}{331521} & Aluminum Die-Casting Foundries & & & & & & & & \\
\hline & TOTAL FUEL CONSUMPTION & 0 & $*$ & 11 & $*$ & 0 & $*$ & $20 \%$ & 0.0 \\
\hline & Indirect Uses-Boiler Fuel & 0 & 0 & $*$ & $*$ & 0 & - & & \\
\hline & Conventional Boiler Use & 0 & 0 & $*$ & 0 & 0 & - & $17.5 \%$ & 0.0 \\
\hline & CHP and/or Cogeneration Process & 0 & 0 & $*$ & $*$ & 0 & - & $17.5 \%$ & 0.0 \\
\hline & Direct Uses-Total Process & 0 & $*$ & 9 & $*$ & 0 & - & & \\
\hline & Process Heating & 0 & 0 & 8 & $*$ & 0 & - & $30 \%$ & 2.4 \\
\hline \multirow[t]{7}{*}{331524} & $\begin{array}{l}\text { Aluminum Foundries, except Die- } \\
\text { Casting }\end{array}$ & & & & & & & & \\
\hline & TOTAL FUEL CONSUMPTION & 0 & $*$ & 8 & $*$ & 0 & $*$ & $20 \%$ & 0.0 \\
\hline & Indirect Uses-Boiler Fuel & 0 & 0 & $*$ & $*$ & 0 & - & & \\
\hline & Conventional Boiler Use & 0 & 0 & $*$ & $*$ & 0 & - & $17.5 \%$ & 0.0 \\
\hline & CHP and/or Cogeneration Process & 0 & 0 & $*$ & 0 & 0 & 一 & $17.5 \%$ & 0.0 \\
\hline & Direct Uses-Total Process & 0 & $*$ & 7 & $*$ & 0 & - & & \\
\hline & Process Heating & 0 & $*$ & 6 & $*$ & 0 & 一 & $30 \%$ & 1.8 \\
\hline \multirow[t]{7}{*}{332} & Fabricated Metal Products & & & & & & & & \\
\hline & TOTAL FUEL CONSUMPTION & $*$ & 3 & 163 & 5 & $\mathrm{Q}$ & $\mathrm{Q}$ & $20 \%$ & 0.0 \\
\hline & Indirect Uses-Boiler Fuel & 0 & $*$ & 21 & $*$ & 0 & - & & \\
\hline & Conventional Boiler Use & 0 & 0 & 11 & 0 & 0 & - & $17.5 \%$ & 1.9 \\
\hline & CHP and/or Cogeneration Process & 0 & $*$ & 10 & $*$ & 0 & - & $17.5 \%$ & 1.8 \\
\hline & Direct Uses-Total Process & 0 & $*$ & 94 & 1 & 0 & 一 & & \\
\hline & Process Heating & 0 & $*$ & 92 & 1 & 0 & - & $30 \%$ & 27.9 \\
\hline \multirow[t]{7}{*}{333} & Machinery & & & & & & & & \\
\hline & TOTAL FUEL CONSUMPTION & $*$ & 3 & 71 & 2 & 0 & 1 & $20 \%$ & 0.2 \\
\hline & Indirect Uses-Boiler Fuel & $*$ & $*$ & 6 & $*$ & 0 & - & & \\
\hline & Conventional Boiler Use & 0 & 0 & 3 & $*$ & 0 & - & $17.5 \%$ & 0.5 \\
\hline & CHP and/or Cogeneration Process & $*$ & $*$ & 3 & 0 & 0 & - & $17.5 \%$ & 0.5 \\
\hline & Direct Uses-Total Process & 0 & 3 & 30 & 1 & 0 & - & & \\
\hline & Process Heating & 0 & $*$ & 28 & $*$ & 0 & - & $30 \%$ & 8.4 \\
\hline \multirow[t]{7}{*}{334} & Computer and Electronic Products & & & & & & & & \\
\hline & TOTAL FUEL CONSUMPTION & $*$ & $*$ & 42 & $*$ & 0 & $*$ & $20 \%$ & 0.0 \\
\hline & Indirect Uses-Boiler Fuel & $*$ & $*$ & 14 & 0 & 0 & - & & \\
\hline & Conventional Boiler Use & 0 & $*$ & 12 & 0 & 0 & - & $17.5 \%$ & 2.1 \\
\hline & CHP and/or Cogeneration Process & $*$ & $*$ & 3 & 0 & 0 & 一 & $17.5 \%$ & 0.5 \\
\hline & Direct Uses-Total Process & 0 & $*$ & 6 & $*$ & 0 & - & & \\
\hline & Process Heating & 0 & $*$ & 5 & $*$ & 0 & - & $20 \%$ & 1.0 \\
\hline 335 & Electric Equipment, Appliances, & & & & & & & & \\
\hline
\end{tabular}




\begin{tabular}{|c|c|c|c|c|c|c|c|c|c|}
\hline $\begin{array}{l}\text { NAICS } \\
\text { code(a) }\end{array}$ & End use & $\begin{array}{c}\text { Residual } \\
\text { fuel oil }\end{array}$ & \begin{tabular}{|c|} 
Distillate \\
fuel oil \\
and \\
diesel \\
fuel(c)
\end{tabular} & $\begin{array}{c}\text { Natural } \\
\text { gas(d) }\end{array}$ & $\begin{array}{c}\text { LPG and } \\
\text { NGL(e) }\end{array}$ & \begin{tabular}{|c|} 
Coal \\
(excluding \\
coke and \\
breeze)
\end{tabular} & $\begin{array}{l}\text { Other } \\
\text { (f) }\end{array}$ & $\begin{array}{c}\text { Percent } \\
\text { waste } \\
\text { heat }\end{array}$ & $\begin{array}{l}\text { Waste heat } \\
\text { TBtu/year } \\
\text { Low temp }\end{array}$ \\
\hline & Components & & & & & & & & \\
\hline & TOTAL FUEL CONSUMPTION & $*$ & 1 & 36 & 1 & 0 & $*$ & $20 \%$ & 0.0 \\
\hline & Indirect Uses-Boiler Fuel & $*$ & $*$ & 6 & $*$ & 0 & - & & \\
\hline & Conventional Boiler Use & $*$ & $*$ & 4 & $*$ & 0 & - & $17.5 \%$ & 0.7 \\
\hline & $\mathrm{CHP}$ and/or Cogeneration Process & 0 & 0 & 3 & $*$ & 0 & - & $17.5 \%$ & 0.5 \\
\hline & Direct Uses-Total Process & $*$ & $*$ & 20 & $*$ & 0 & - & & \\
\hline & Process Heating & 0 & $*$ & 19 & $*$ & 0 & - & $20 \%$ & 3.8 \\
\hline \multirow[t]{7}{*}{336} & Transportation Equipment & & & & & & & & \\
\hline & TOTAL FUEL CONSUMPTION & 2 & 3 & 127 & 3 & 3 & 5 & $20 \%$ & 1.0 \\
\hline & Indirect Uses-Boiler Fuel & 2 & $*$ & 30 & $*$ & 3 & - & & \\
\hline & Conventional Boiler Use & 2 & $*$ & 13 & $*$ & 3 & - & $17.5 \%$ & 3.2 \\
\hline & CHP and/or Cogeneration Process & 0 & $*$ & 16 & $*$ & 0 & - & $17.5 \%$ & 2.8 \\
\hline & Direct Uses-Total Process & $*$ & 1 & 52 & 1 & 0 & - & & \\
\hline & Process Heating & $*$ & $*$ & 43 & $*$ & 0 & - & $20 \%$ & 8.6 \\
\hline \multirow[t]{7}{*}{337} & Furniture and Related Products & & & & & & & & \\
\hline & TOTAL FUEL CONSUMPTION & 0 & $*$ & 13 & 1 & $\mathrm{Q}$ & 4 & $20 \%$ & 0.8 \\
\hline & Indirect Uses-Boiler Fuel & 0 & 0 & 1 & 0 & $*$ & - & & \\
\hline & Conventional Boiler Use & 0 & 0 & $*$ & 0 & $*$ & 一 & $17.5 \%$ & 0.0 \\
\hline & CHP and/or Cogeneration Process & 0 & 0 & 1 & 0 & 0 & 一 & $17.5 \%$ & 0.2 \\
\hline & Direct Uses-Total Process & 0 & $*$ & 5 & $*$ & 0 & - & & \\
\hline & Process Heating & 0 & $*$ & 5 & $*$ & 0 & 一 & $20 \%$ & 1.0 \\
\hline \multirow[t]{8}{*}{339} & Miscellaneous & & & & & & & & \\
\hline & TOTAL FUEL CONSUMPTION & $*$ & 1 & 16 & $*$ & $*$ & $*$ & $20 \%$ & 0.0 \\
\hline & Indirect Uses-Boiler Fuel & 0 & $*$ & 5 & $*$ & 0 & - & & \\
\hline & Conventional Boiler Use & 0 & $*$ & 3 & 0 & 0 & - & $17.5 \%$ & 0.5 \\
\hline & $\mathrm{CHP}$ and/or Cogeneration Process & 0 & $*$ & 3 & $*$ & 0 & - & $17.5 \%$ & 0.5 \\
\hline & Direct Uses-Total Process & 0 & $*$ & 5 & $*$ & 0 & - & & \\
\hline & Process Heating & 0 & $*$ & 4 & $*$ & 0 & 一 & $20 \%$ & 0.8 \\
\hline & Total for NAICS 331 - 339 & & & & & & & Total & 360.7 \\
\hline
\end{tabular}

\#The waste heat considered in this study includes only waste heat from flue gases and excludes all other losses such as wall loss, opening loss etc. The percent waste heat estimates are based on the available heat analysis or stack loss estimates of the energy systems (Boilers, CHP and process heating).

*Estimates less than 0.5

\section{Abbreviations in Appendix B:}

LPG - Liquid Petroleum Gas

NGL - Natural Gas Liquids

W - Withheld to avoid disclosing data for individual establishments.

Q - Withheld because Relative Standard Error is greater than 50 percent. 